US Army Corps

of Engineers $S_{\circledast}$

Engineer Research and

Development Center

Missouri River Recovery Program (MRRP)

Hydrologic Engineering Center-River Analysis System (HEC-RAS) Water Temperature Models Developed for the Missouri River Recovery Management Plan and Environmental Impact Statement

Zhonglong Zhang and Billy E. Johnson

September 2017 
The U.S. Army Engineer Research and Development Center (ERDC) solves the nation's toughest engineering and environmental challenges. ERDC develops innovative solutions in civil and military engineering, geospatial sciences, water resources, and environmental sciences for the Army, the Department of Defense, civilian agencies, and our nation's public good. Find out more at www.erdc.usace.army.mil.

To search for other technical reports published by ERDC, visit the ERDC online library at http://acwc.sdp.sirsi.net/client/default. 


\title{
Hydrologic Engineering Center-River Analysis System (HEC-RAS) Water Temperature Models Developed for the Missouri River Recovery Management Plan and Environmental Impact Statement
}

Billy E. Johnson

\author{
Environmental Laboratory \\ U.S. Army Engineer Research and Development Center \\ 3909 Halls Ferry Road \\ Vicksburg, MS 39180-6199 \\ Zhonglong Zhang \\ Limno Tech \\ $7074^{\text {th }}$ Street \\ Davis, CA 95616
}

Final report

Approved for public release; distribution is unlimited.

\author{
Prepared for U.S. Army Corps of Engineers \\ Washington, DC 20314-1000 \\ Under Project 396939, “Missouri River Recovery Management Plan and \\ Environmental Impact Statement"
}




\section{Abstract}

This report describes the Hydrologic Engineering Center-River Analysis System (HEC-RAS) water temperature models developed for five Missouri river reaches (e.g., Fort Peck Dam to Garrison Dam; Garrison Dam to Oahe; Fort Randall Dam to Gavins Point Dam; Gavins Point Dam to Rulo, NE; and Rulo, NE to the mouth of the Missouri River). These models were developed based on calibrated HEC-RAS flow models that the Omaha and Kansas City Districts of the U.S. Army Corps of Engineers (USACE) provided. Of five HEC-RAS water temperature models, three models were run for an 18-year period (1995-2012) for six alternatives in support of developing the Missouri River recovery program (MRRP) management plan (ManPlan) and environmental impact statement (EIS). The HECRAS water temperature model results for each river reach and each alternative are presented in this report. Likewise, the sources of model uncertainty are discussed in this report as well.

DISCLAIMER: The contents of this report are not to be used for advertising, publication, or promotional purposes. Citation of trade names does not constitute an official endorsement or approval of the use of such commercial products. All product names and trademarks cited are the property of their respective owners. The findings of this report are not to be construed as an official Department of the Army position unless so designated by other authorized documents. 


\section{Contents}

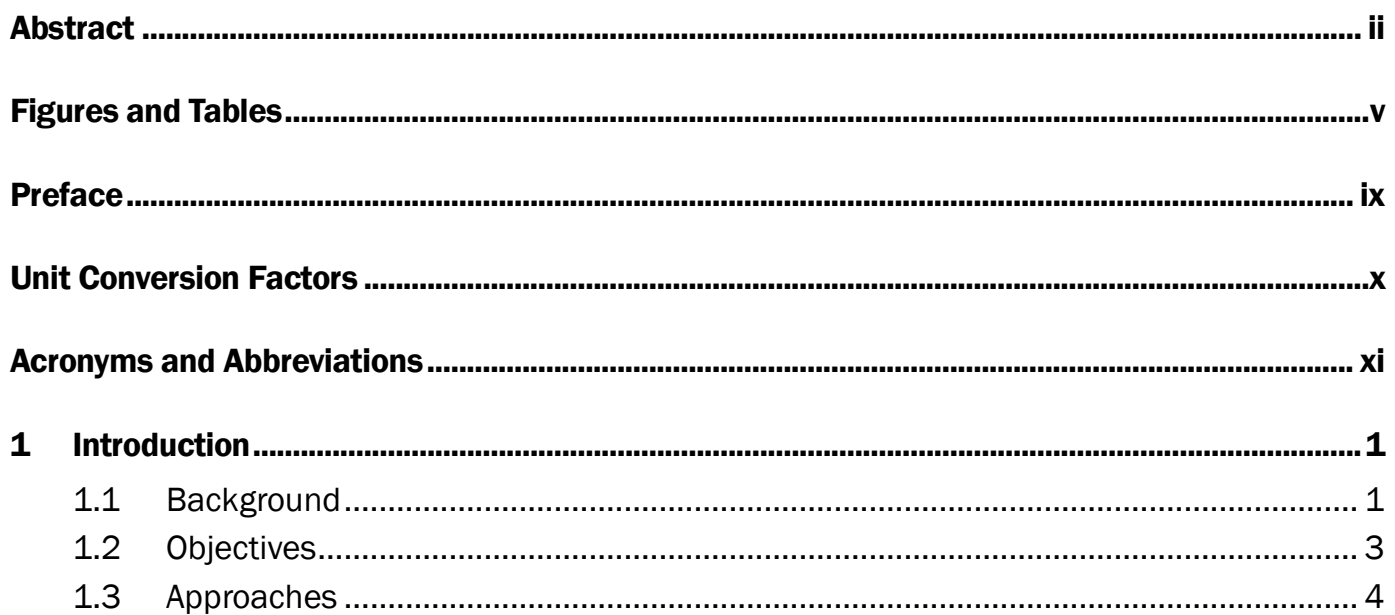

2 Missouri River HEC-RAS Flow Models ............................................................................... 5

3 HEC-RAS Water Temperature Model Description and Input Requirements .......................... 8

3.1 Water temperature model description .................................................................... 8

3.2 Water temperature model input requirements .................................................... 12

3.2.1 Meteorological data ......................................................................................... 13

3.2.2 Water temperature boundaries.................................................................. 13

4 Missouri River HEC-RAS Water Temperature Models ..........................................................14

4.1 Meteorological data ......................................................................................... 14

4.2 Water temperature boundary conditions ......................................................... 18

4.2.1 Regression relationship between air and water temperatures............................20

4.2.2 Application of the regression equations to compute water temperatures

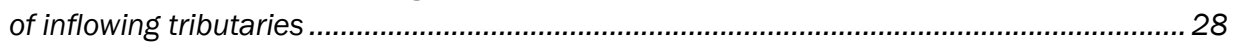

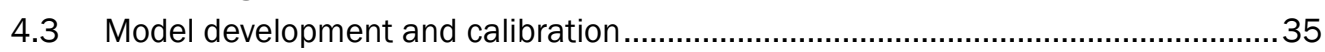

4.3.1 Fort Peck Dam to Garrison Dam River Reach ..................................................... 35

4.3.2 Garrison Dam to Oahe Dam River Reach ........................................................42

4.3.3 Fort Randall Dam to Gavins Point Dam River Reach .......................................... 48

4.3.4 Gavins Point Dam to Rulo River Reach.......................................................... 51

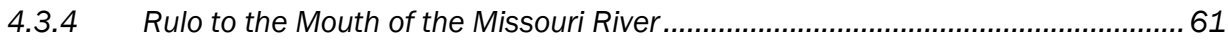

5 Missouri River HEC-RAS Water Temperature Model Results for Alternatives......................69

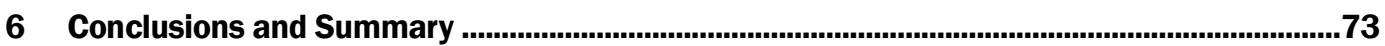

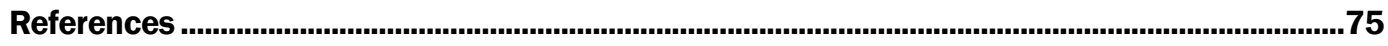

Appendix A. Time Series Plots of Regression Computed versus Observed Water

Temperatures for the Garrison Dam to Oahe Dam River Reach............................................78

Appendix B. Time Series Plots of Regression Computed versus Observed Water

Temperatures for the Gavins Point Dam to Rulo River Reach 
Appendix C. Time Series Plots of Regression Computed versus Observed Water Temperatures for the Rulo to the mouth of the Missouri River.

Report Documentation Page 


\section{Figures and Tables}

\section{Figures}

Figure 1. Missouri River modeling framework for the effects analysis and the management plan analysis (Fischenich et al. 2014)

Figure 2. HEC-RAS modeled reaches on the Missouri River (USACE 2015).

Figure 3. Sources and sinks of heat energy at the atmospheric and sediment interfaces (Deas and Lowney 2000).

Figure 4. Distribution of meteorological stations used in the Missouri River HEC-RAS models.

Figure 5. Data gaps of observed hourly (a) solar radiation and (b) air temperature at KOMA, NE.

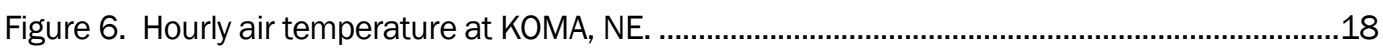

Figure 7. Scatter plot of observed water versus air temperatures at USGS 0689300....................23

Figure 8. Observed vs. linear-regression-computed water temperatures at USGS

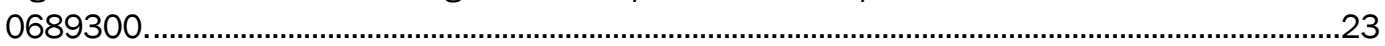

Figure 9. Scatter plot of observed water versus air temperatures at USGS 05587455..................24

Figure 10. Observed vs. regression-computed water temperatures at USGS 05587455...............25

Figure 11. Observed vs regression computed water temperatures at USGS $0689300 \ldots \ldots \ldots \ldots \ldots . . . . . . .26$

Figure 12. Observed and regression computed water temperatures at USGS 05587455.............27

Figure 13. Water quality monitoring gages and correlated meteorological stations for the Garrison Dam to Oahe Dam reach.

Figure 14. Water quality monitoring gages and correlated meteorological stations for the lower Missouri River from the Givens Point Dam to the mouth of the Missouri River.

Figure 15. HEC-RAS model extent for the Fort Peck Dam to Garrison Dam reach (USACE 2015).

Figure 16. HEC-RAS predicted versus observed water temperatures of the Missouri River at Frazer, MT.

Figure 17. HEC-RAS predicted versus observed water temperatures of the Missouri River at Wolf, MT.

Figure 18. HEC-RAS predicted versus observed water temperatures of the Missouri River at Culbertson, MT.

Figure 19. HEC-RAS predicted versus observed water temperatures of the Missouri River at Nohly, MT...

Figure 20. HEC-RAS predicted versus observed water temperatures of the Missouri River at Williston, MT.

Figure 21. HEC-RAS model extent for the Garrison Dam to Oahe Dam reach (USACE 2015).

Figure 22. Schematic representation of inflow boundary locations included in the HECRAS model for the Garrison Dam to Oahe Dam reach.

Figure 23. Schematic and data plan of the HEC-RAS temperature model for the Garrison Dam to Oahe Dam reach.

Figure 24. HEC-RAS predicted versus observed water temperatures of the Missouri River at Washburn, ND (USGS 06341000). 
Figure 25. HEC-RAS predicted versus observed water temperatures of the Missouri River at Bismarck, ND (USGS 06342500).

Figure 26. HEC-RAS model extent for the Fort Randall Dam to Gavins Point Dam reach (USACE 2015).

Figure 27. HEC-RAS predicted versus observed water temperatures of the Missouri River at Springfield, SD (USGS 06466700).

Figure 28. HEC-RAS model extent for the Gavins Point Dam to Rulo reach (USACE 2015). ............52

Figure 29. Schematic representation of inflow boundary locations included in the HECRAS model for the Gavins Point Dam to the Rulo reach.

Figure 30. Schematic and data plan of the HEC-RAS temperature model for the Gavins Point Dam to Rulo reach.

Figure 31. HEC-RAS water temperature calibration locations from the Gavins Point Dam to the mouth of the Missouri River.

Figure 32. HEC-RAS predicted versus observed water temperatures of the Missouri River near Maskell, NE (USGS 06478526).

Figure 33. HEC-RAS predicted versus observed water temperatures of the Missouri River at Sioux City, IA (USGS 06486000).

Figure 34. HEC-RAS predicted versus observed water temperatures of the Missouri River at Decatur, NE (USGS 06601200).

Figure 35. HEC-RAS predicted versus observed water temperatures of the Missouri River at Omaha, NE (USGS 06610000).

Figure 36. HEC-RAS predicted versus observed water temperatures of the Missouri River at Nebraska City, NE (USGS 06807000).

Figure 37. HEC-RAS predicted versus observed water temperatures of the Missouri River at Rulo, NE (USGS 06813500).

Figure 38. HEC-RAS model extent for the Rulo to the Mouth of the Missouri River reach (USACE 2015).

Figure 39. Schematic representation of inflow boundary locations included in the HECRAS model from Rulo to the mouth of the Missouri River.

Figure 40. Schematic and data plan of the HEC-RAS temperature model for the Rulo to the Mouth of the Missouri River.

Figure 41. HEC-RAS predicted versus observed water temperatures of the Missouri River at St. Joseph, MO (USGS 06818000).

Figure 42. HEC-RAS predicted versus observed water temperatures of the Missouri River at Kansas City, MO (USGS 06893000).

Figure 43. HEC-RAS predicted versus observed water temperatures of the Missouri River at Waverly, MO (USGS 06895500).

Figure 44. HEC-RAS predicted versus observed water temperatures of the Missouri River at Gasgow, MO (USGS 06906500).

Figure 45. HEC-RAS predicted versus observed water temperatures of the Missouri River at Hermann, MO (USGS 06934500).

Figure 46. Model predicted daily mean flow discharge at Missouri River RM 625.22 for alternatives 1 and 7 .

Figure 47. Model predicted daily mean water temperatures at Missouri River RM 625.22 for alternatives 1 and 7 ...

Figure A1. Regression computed versus observed water temperatures at BC1. 
Figure A2. Regression computed versus observed water temperatures at BC2. ………................79

Figure A3. Regression computed versus observed water temperatures at BC3. ……....................79

Figure A4. Regression computed versus observed water temperatures at BC4. ............................8

Figure A5. Regression computed versus observed water temperatures at BC5 .............................80

Figure A6. Regression computed versus observed water temperatures at BC6. ...........................81

Figure A7. Regression computed versus observed water temperatures at $\mathrm{BC} 7$. .............................81

Figure A8. Regression computed versus observed water temperatures at BC8. ............................82

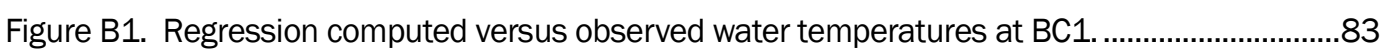

Figure B2. Regression computed versus observed water temperatures at BC2 ............................84

Figure B3. Regression computed versus observed water temperatures at BC3..............................84

Figure B4. Regression computed versus observed water temperatures at BC4............................85

Figure B5. Regression computed versus observed water temperatures at BC5.............................85

Figure B6. Regression computed versus observed water temperatures at BC6 ............................86

Figure B7. Regression computed versus observed water temperatures at BC7 ..............................86

Figure B8. Regression computed versus observed water temperatures at BC8.............................87

Figure B9. Regression computed versus observed water temperatures at BC9.............................87

Figure B10. Regression computed versus observed water temperatures at $\mathrm{BC} 10$. ........................8

Figure B11. Regression computed versus observed water temperatures at BC11........................88

Figure B12. Regression computed versus observed water temperatures at $\mathrm{BC} 12$.........................89

Figure B13. Regression computed versus observed water temperatures at $\mathrm{BC} 13$..........................89

Figure B14. Regression computed versus observed water temperatures at BC14 ........................90

Figure B15. Regression computed versus observed water temperatures at $\mathrm{BC} 15$. ........................90

Figure B16. Regression computed versus observed water temperatures at BC16 .......................91

Figure $\mathrm{C} 1$. Regression computed versus observed water temperatures at $\mathrm{BC} 1$............................92

Figure $\mathrm{C} 2$. Regression computed versus observed water temperatures at $\mathrm{BC} 2$............................93

Figure C3. Regression computed versus observed water temperatures at $\mathrm{BC} 3 \ldots \ldots \ldots \ldots \ldots \ldots . . . . . . . . . . . . . .93$

Figure C4. Regression computed versus observed water temperatures at BC4............................94

Figure C5. Regression computed versus observed water temperatures at BC5..............................94

Figure C6. Regression computed versus observed water temperatures at BC6.............................95

Figure C7. Regression computed versus observed water temperatures at BC7 .............................95

Figure C8. Regression computed versus observed water temperatures at $\mathrm{BC} 8$..............................96

Figure C9. Regression computed versus observed water temperatures at BC9.............................96

Figure C10. Regression computed versus observed water temperatures at $\mathrm{BC} 10$. .........................97

Figure C11. Regression computed versus observed water temperatures at $\mathrm{BC} 11$........................97

Figure C12. Regression computed versus observed water temperatures at $\mathrm{BC} 12$.........................98

Figure C13. Regression computed versus observed water temperatures at BC13. ........................98

Figure C14. Regression computed versus observed water temperatures at $\mathrm{BC} 14$. ........................99

Figure C15. Regression computed versus observed water temperatures at BC15 ........................99

Figure C16. Regression computed versus observed water temperatures at BC16. ..................... 100

Figure C17. Regression computed versus observed water temperatures at BC17...................... 100 
Figure C18. Regression computed versus observed water temperatures at BC18. .................... 101

Figure C19. Regression computed versus observed water temperatures at BC19. ..................... 101

Figure C20. Regression computed versus observed water temperatures at BC20 ...................... 102

Figure C21. Regression computed versus observed water temperatures at BC21...................... 102

Figure C22. Regression computed versus observed water temperatures at BC22. ..................... 103

Figure C23. Regression computed versus observed water temperatures at $\mathrm{BC} 23 . . . . . . . . . . . . . . . . . . . .103$

Figure C24. Regression computed versus observed water temperatures at BC24 ....................... 104

Figure C25. Regression computed versus observed water temperatures at BC25...................... 104

Figure C26. Regression computed versus observed water temperatures at BC26. ..................... 105

Figure C27. Regression computed versus observed water temperatures at BC27........................ 105

\section{Tables}

Table 1. Meteorological stations along the Missouri river and their locations and elevations. 16

Table 2. Summary of air and water temperature regression models for rivers and streams.

Table 3. Water temperature boundaries derived from water quality monitoring gages and meteorological stations. 30

Table 4. Statistics for each boundary condition and each regression equation.

Table 5. Flow and temperature boundaries included in the HEC-RAS model for the Fort Peck Dam to Garrison Dam reach

Table 6. Inflow and temperature boundaries included in the HEC-RAS model for the Garrison Dam to Oahe Dam reach.

Table 7. Flow and temperature boundaries included in the HEC-RAS model for the Fort Randall Dam to Gavins Point Dam reach

Table 8. Inflow and temperature boundaries included in the HEC-RAS model for the Gavins Point Dam to Rulo reach.

Table 9. Inflow and temperature boundaries included in the HEC-RAS model from Rulo to the mouth of the Missouri River. 63

Table 10. List of alternatives evaluated with the Missouri River HEC-RAS models.

Table 11. List of HEC-RAS water temperature model output locations along the Missouri River. 


\section{Preface}

This study was conducted as part of the Missouri River Recovery Program (MRRP), Project Number 396939, "MRRP Management Plan (ManPlan) and Environmental Impact Statement (EIS).” Mr. Jeff Tripe of USACE Kansas City District was the Program Manager.

This report was prepared by Dr. Zhonglong Zhang of LimnoTech, under contract to the U.S. Army Engineer Research and Development Center (ERDC) and Dr. Billy Johnson of the Water Quality and Contaminant Modeling Branch (WQCMB), Environmental Processes and Engineering Division (EPED), Environmental Laboratory (EL) of ERDC. At the time of publication, Mr. Mark Noel was acting chief, WQCMB; and Mr. Warren Lorentz was chief, EPED. The Deputy Director of ERDC-EL was Dr. Jack Davis and the Director was Dr. Beth Fleming.

Additionally, Mr. Mark Jensen and Mr. Todd Steissberg of the HEC, Mr. Zachary Jelenek of the Sacramento District, and Mr. Barry Bunch of WQCMB provided support for the HEC-RAS model improvement, model input data processing, and model execution. Mr. Mark Dortch of WQMCB and Ms. Laurel Hamilton of the Omaha District reviewed the report

COL Bryan S. Green was Commander of ERDC, and Dr. David W. Pittman was the Director 


\section{Unit Conversion Factors}

\begin{tabular}{|l|l|l|}
\hline Multiply & \multicolumn{1}{|c|}{ By } & To Obtain \\
\hline degrees Fahrenheit ( $\left.{ }^{\circ} \mathrm{F}\right)$ & $(\mathrm{F}-32) / 1.8$ & degrees Celsius $\left({ }^{\circ} \mathrm{C}\right)$ \\
\hline day (d) & 86400 & second $(\mathrm{s})$ \\
\hline feet (ft) & 0.3048 & meters $(\mathrm{m})$ \\
\hline cubic feet (ft3) & 0.02831685 & cubic meters $\left(\mathrm{m}^{3}\right)$ \\
\hline liter (L) & 0.001 & cubic meters $\left(\mathrm{m}^{3}\right)$ \\
\hline gram (g) & $10-6$ & micrograms $(\mu \mathrm{g})$ \\
\hline gram (g) & $10^{-9}$ & nanograms $(\mathrm{ng})$ \\
\hline pounds (mass) (lb) & 453.59 & grams $(\mathrm{g})$ \\
\hline pounds (mass) (lb) & 0.45359237 & Kilograms $(\mathrm{kg})$ \\
\hline pounds (mass) per cubic foot $\left(\mathrm{lb} / \mathrm{ft}^{3}\right)$ & 16.01846 & kilograms per cubic meter $\left(\mathrm{kg} / \mathrm{m}^{3}\right)$ \\
\hline pounds (mass) per square foot $\left(\mathrm{lb} / \mathrm{ft}^{2}\right)$ & 4.882428 & kilograms per square meter $\left(\mathrm{kg} / \mathrm{m}^{2}\right)$ \\
\hline gallons (U.S. liquid) (gal) & $3.785412 \mathrm{E}-03$ & cubic meters $\left(\mathrm{m}^{3}\right)$ \\
\hline calories (Cal) & 4.184 & joule $(\mathrm{J})$ \\
\hline
\end{tabular}




\section{Acronyms and Abbreviations}

1-D

2-D

ATEM

BASINS

BC

$\mathrm{BiOp}$

CLOU

DEWP

EA

EIS

ERDC

$\mathrm{ESH}$

ESA

HEC-DSS

HEC-EFM

HEC-RAS

HEC-ResSim

One dimensional

Two dimensional

air temperature

Better Assessment Science Integrating Point and

Nonpoint Sources

Boundary Condition

Biological Opinion of the U.S. Fish and Wildlife Service

cloud cover

dew point

Effects Analysis

Environmental Impact Statement

U.S. Army Engineer Research and Development Center

Emergent Sandbar Habitat

Endangered Species Act

Hydrologic Engineering Center-Data Storage System

Hydrologic Engineering Center-Ecosystem Functions Model

Hydrologic Engineering Center-River Analysis Systems

Hydrologic Engineering Center-Reservoir System Simulation

HSPF

Hydrological Simulation Program--Fortran

IRC

Interception Rearing Complex 


\begin{tabular}{|c|c|}
\hline MAF & million acre feet \\
\hline ManPlan & Management Plan \\
\hline MRRIC & Missouri River Recovery Implementation Committee \\
\hline MRRP & Missouri River Recovery Program \\
\hline NSM & Nutrient Simulation Module \\
\hline NWS & National Weather Service \\
\hline QUICKEST & $\begin{array}{l}\text { Quadratic Upwind Interpolation for Convection } \\
\text { Kinematics with Estimated Streaming Terms }\end{array}$ \\
\hline $\mathrm{RM}$ & River Mile \\
\hline RMSE & Root Mean Square Error \\
\hline SOLR & short wave solar radiation \\
\hline SWAT & Soil and Water Assessment Tool \\
\hline SWH & Shallow Water Habitat \\
\hline ULTIMATE & $\begin{array}{l}\text { Universal Limiter for Transient Interpolation Modeling } \\
\text { of Advective Transport Equation }\end{array}$ \\
\hline USACE & U.S. Army Corps of Engineers \\
\hline USAFETAC & $\begin{array}{l}\text { U.S. Air Force Environmental Technical Applications } \\
\text { Center }\end{array}$ \\
\hline USEPA & U.S. Environmental Protection Agency \\
\hline USFWS & U.S. Fish and Wildlife Service \\
\hline USGS & U.S. Geological Survey \\
\hline NIND & wind speed \\
\hline
\end{tabular}




\section{Introduction}

\subsection{Background}

The Kansas City and Omaha Districts of the U.S. Army Corps of Engineers (USACE), in cooperation with the U.S. Fish and Wildlife Service (USFWS), have developed the MRRP ManPlan and EIS. As stated in "Draft Missouri River Recovery Management Plan and Environmental Impact

Statement" (USACE 2016), USACE has a responsibility under the Endangered Species Act (ESA) to take actions to ensure that the operation of the Missouri River is not likely to jeopardize the continued existence of threatened and endangered species or adversely modify critical habitat. The purpose of the ManPlan and EIS is to develop a suite of actions that meets ESA responsibilities for the threatened and endangered species (e.g., Pallid Sturgeon, Least Tern and Piping Plover). The geographic scope of the ManPlan and EIS is limited to the Missouri River main stem from Fort Peck Reservoir to the confluence of the Mississippi River and the Yellowstone River from Intake Dam at Intake, Montana, to the confluence with the Missouri River (USACE 2016).

As Fischenich et al. (2014) outlined, ManPlan and EIS analyses are accomplished through a series of models recommended by technical working groups. These models will quantify the relationships among habitat conditions, habitat requirements, and species' demographics as well as evaluate the effectiveness of current habitat development and recommend any needed modifications to more effectively create habitat and avoid peril of threatened and endangered species. Specifically, predictions of future population size, growth, and distribution must be quantified as a function of past and future management actions, such as habitat alteration/manipulation through flow management and habitat creation as well as other drivers and stressors, which include climate and predation. Figure 1 presents the Missouri River modeling framework for the effects analysis (EA) and ManPlan analysis. The framework shown in Figure 1 includes components specific to the ManPlan in addition to those serving both the EA and the ManPlan. Outputs from the species models and the ManPlan models will feed into a structured decision process to consider impacts, benefits, and tradeoffs among the objectives. 
Figure 1. Missouri River modeling framework for the effects analysis and the management plan analysis (Fischenich et al. 2014).

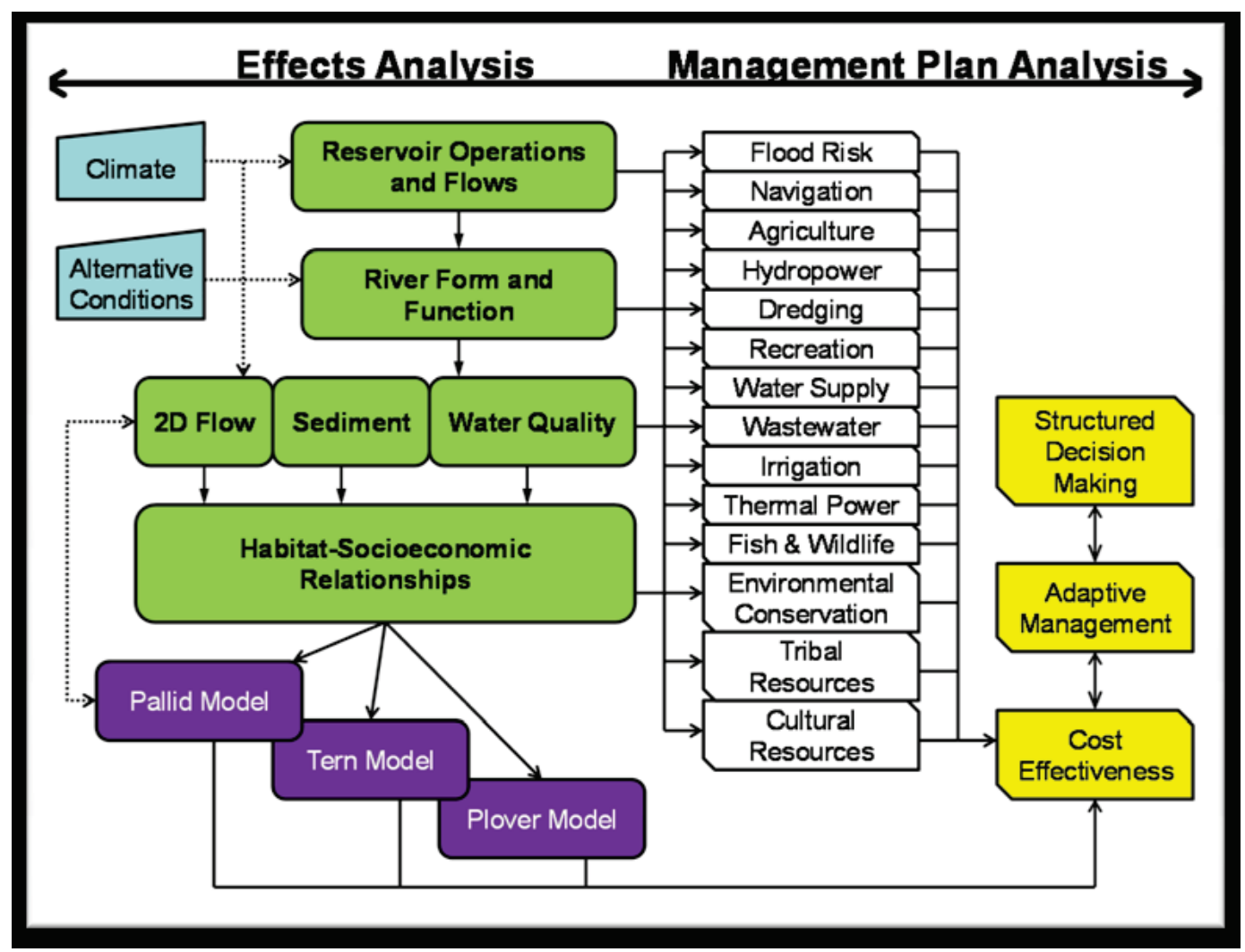

The above framework utilizes several HEC models. Main stem Missouri River reservoir operations are modeled using HEC-Reservoir System Simulation (ResSim); HEC-RAS models of riverine reaches are used to support flow, sediment transport and water quality analyses. HEC-ResSim model outputs are used as inputs to the HEC-RAS flow models. The HECEcosystems Function Model (EFM) is used to integrate time series flow data from the HEC-RAS models with other relevant information to quantify habitat availability. Two-dimensional (2-D) hydrodynamic and sediment modeling of representative reaches will supplement the HEC models, providing critical insight into important processes that cannot be properly assessed using one dimensional (1-D) models alone.

As the water quality group identified (USACE 2014b), the 1-D longitudinal (i.e., along river flow axis) HEC-RAS along with the aquatic nutrient simulation module (NSM) was chosen as the preferred riverine water quality model for simulating current conditions and evaluating management strategies for the river reaches on the Missouri River. The HEC-RAS-NSM was chosen based on its capability and compatibility with existing Missouri River HEC-RAS flow models USACE developed (USACE 
2015). HEC-RAS-NSM can model water temperature, nutrients, and eutrophication in 1-D riverine systems.

ERDC-EL was tasked to apply the latest HEC-RAS-NSM model to simulate the water temperature for the river reaches of the Missouri River, from Fort Peck, MT, to St. Louis, MO, in support of the ManPlan and the EIS. Water temperature is a primary indicator of the physical, chemical, and biological health of aquatic ecosystems. Modeled water temperatures along the Missouri River have been used for alternative analysis under the ManPlan and the EIS. USACE Omaha and Kansas City Districts developed five discrete HEC-RAS flow models for simulating river reaches of the Missouri River's main stem. These river reaches are Fort Peck Dam to Garrison Dam; Garrison Dam to Oahe Dam; Fort Randall Dam to Gavins Point Dam; Gavins Point Dam to Rulo, NE, and Rulo, NE, to the mouth of the Missouri River at St. Louis, MO. HEC-RAS models described in the report only simulate river reaches and do not simulate the reservoirs on the Missouri River. The HEC-RAS water temperature models were developed based on the calibrated flow models the USACE Omaha and Kansas City Districts provided. Likewise, the HEC-RAS water temperature models were used to simulate current conditions on the Missouri River, with the intention of running management scenarios to compare alternatives.

\subsection{Objectives}

Water temperature in streams and rivers is an important attribute of water quality and controls the health of freshwater ecosystems. Various human activities such as industrial production, deforestation and thermal pollution, will affect water temperature, and hence impact fish habitats and aquatic organisms. The overall goal of the project is to expand the existing HEC-RAS flow models for simulating current conditions of water temperature along the Missouri River, with the intention of running management scenarios to compare alternatives.

This study is a work in progress. Useful data will be pursued to revise the models as necessary to meet the study objectives. As additional information is identified, or otherwise becomes available, the HEC-RAS water temperature models discussed in this report will be updated and improved. 


\subsection{Approaches}

The tool used in this study was the 1-D HEC-RAS model. HEC-RAS water temperature models were developed based on the calibrated HEC-RAS flow models that USACE Omaha and Kansas City Districts provided. These HEC-RAS flow models are described in a separate USACE report (USACE 2015). Meteorological data and inflow water temperatures are primary model inputs for running a HEC-RAS water temperature model. Hourly meteorological data were obtained from the U.S. Air Force Environmental Technical Applications Center (USAFETAC) in Asheville, $\mathrm{NC}$ and the U.S. Environmental Protection Agency (USEPA) website. Because of limited observed water temperature data, boundary conditions for all inflow water temperatures used in the HEC-RAS models were computed from multiple air - water temperature regression relationships. Regression methods were used to estimate missing data and compute long-term time series (18 years) boundary conditions along the Missouri River for the HEC-RAS water temperature models in support of conducting the ManPlan and EIS analysis. 


\section{Missouri River HEC-RAS Flow Models}

The Missouri River flows for 2,341 miles from Three Forks, MT through the states of Montana, North Dakota, South Dakota, Nebraska, Iowa, Kansas, and Missouri. It is the longest river in the United States and drains one sixth of the contiguous United States, an area of 529,350 square miles. USACE operates six dams and reservoirs with a capacity to store 72.4 million acre feet (MAF) of water, the largest reservoir system in North America. USACE operates the system to serve eight congressionally authorized project purposes of flood control, navigation, irrigation, hydropower, water supply, water quality, recreation, and fish and wildlife. Runoff from the upper Missouri River Basin is stored in reservoirs behind the main stem dams: Fort Peck, Garrison, Oahe, Big Bend, Fort Randall, and Gavins Point. Released water from the lowest dam in the system, Gavins Point Dam, flows down the lower Missouri River from Sioux City, IA to St. Louis, MO (Figure 2).

USACE Omaha and Kansas City Districts developed five separate HECRAS unsteady flow models for discrete reaches of the main stem of the Missouri River in support of ManPlan and EIS (USACE 2015). Figure 2 lays out the model extent and locations of the five individual HEC-RAS models. The geographic domains of the five HEC-RAS models are defined as follows.

- Fort Peck Dam to Garrison Dam river reach: begins with the regulated outflow from Fort Peck Dam in MT and extends approximately 382 miles downstream, to just upstream of Garrison Dam on Lake Sakakawea, ND.

- Garrison Dam to Oahe Dam river reach: begins with the regulated outflow from Garrison Dam in ND and extends approximately 318 miles downstream to just upstream of Oahe Dam on Lake Oahe, SD.

- Fort Randall Dam to Gavins Point Dam river reach: begins with the regulated outflow from Fort Randall Dam in SD and extends 69 miles downstream to just upstream of Gavins Point Dam on Lewis and Clark Lake.

- Gavins Point Dam to Rulo, NE of the Missouri River: begins with the regulated outflow from Gavins Point Dam in SD at river mile (RM) 811.1 and extends approximately 313 miles downstream to Rulo, NE, at RM 498.0. 
- Rulo, NE to the mouth of the Missouri River: includes the lower 498mile stretch contained within the boundary of the USACE Kansas City District as well as the Mississippi River between Grafton and St. Louis.

Figure 2. HEC-RAS modeled reaches on the Missouri River (USACE 2015).

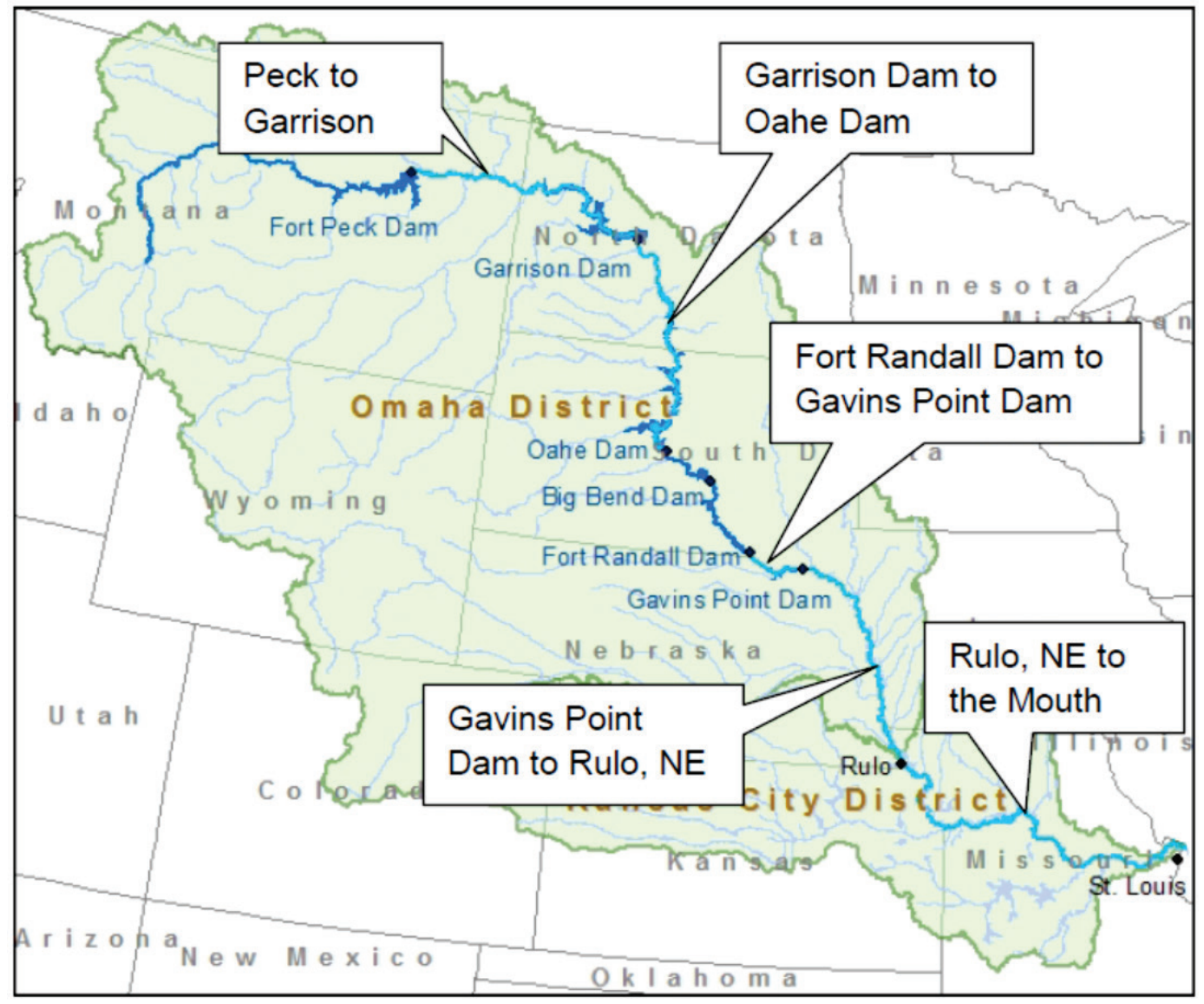

The HEC-RAS model was only used for simulating the free-flowing river reaches, not reservoirs on the Missouri River. Six reservoirs were modeled using HEC-ResSim and CE-QUAL-W2 models. A separate ManPlan and EIS report describes the five Missouri River HEC-RAS flow models (USACE 2015). In addition to the modeling the Missouri River, major tributaries were included as separate routing reaches within the HEC-RAS model in order to more accurately route flows from the tributary gage to the main stem. Minor tributaries that have U.S. Geological Survey (USGS) gage data were included as lateral inflow to the model. Numerous ungaged inflows were also included in these HEC-RAS flow models. Ungaged inflow represents that portion of the flow that is not captured by the gage station records and then calculated between two gages on the main stem, which has a continuous record of both stage and flow. As 
described in the district report (USACE 2015), the HEC-RAS flow models were developed using the best available ground LIDAR and hydrographic survey data. These models were calibrated by using relatively recent high and low flow events (within bank), as well as recent mid-level flooding, and extreme events (e.g., 1993 and/ or 2011).

These HEC-RAS flow models were used to support riverine modeling needs associated with the ManPlan and EIS. The HEC-RAS modeling effort outputs support conceptual and quantitative ecological models that evaluate species responses to management actions, examine the effects to basin stakeholder interests, and assess authorized purposes in the ManPlan and EIS analysis. The HEC-RAS flow models were also used as flow drivers for corresponding reach water temperature models described in this report. Water temperature analysis for the study period has been undertaken to produce temperature information that serves as a baseline (no action condition) against which alternatives were assessed. 


\section{HEC-RAS Water Temperature Model Description and Input Requirements}

The HEC-RAS water temperature model simulates hydraulics as well as in-stream heat and mass transfer processes related to stream temperature dynamics. This chapter briefly discusses the water temperature transport and source/sink formulation and its input requirements.

\subsection{Water temperature model description}

Heat storage capacity, along with a stream's response to thermal energy inputs and the influence of inflow water temperatures, is a function of stream velocity and water depth, which are determined by the spatial and temporal variations in the hydrologic regime. Additionally, surface and subsurface runoff entering or interacting with stream networks can be significant sources of thermal energy (Nelson and Palmer 2007; Herb and Stefan 2011). Variability in topography, channel morphology (width, depth, slope, and orientation), along with bankside vegetation characteristics affect the stream surface area available for solar heating and, in turn, control the instream energy and water balances.

The HEC-RAS water temperature model solves the 1-D advectiondispersion equation for thermal energy with additional terms to account for lateral inflow, solar radiation, and the heat exchange with the atmosphere and streambed. Lateral inflow represents additional water entering the model domain as surface inflow, overland flow, interflow, and groundwater discharge. The $1 \mathrm{D}$ heat transport equation is given as (HEC 2016):

$$
\frac{\partial}{\partial t}\left(V T_{w}\right)=-\frac{\partial}{\partial x}\left(Q T_{w}\right) \Delta x+\frac{\partial}{\partial x}\left(A D_{x} \frac{\partial T_{w}}{\partial x}\right) \Delta x+S_{L}+S
$$

where

$$
\begin{aligned}
V & =\text { volume of the computational cell }\left(\mathrm{m}^{3}\right) \\
T_{w} & =\text { water temperature }\left({ }^{\circ} \mathrm{C}\right) \\
t & =\text { time }(\mathrm{s}) \\
Q & =\text { flow rate }\left(\mathrm{m}^{3} \mathrm{~s}^{-1}\right) \\
A & =\text { channel cross-sectional area }\left(\mathrm{m}^{2}\right) \\
x & =\text { distance along channel }(\mathrm{m})
\end{aligned}
$$




$$
\begin{aligned}
\Delta x= & \text { distance between cross sections }(\mathrm{m}) \\
D x= & \text { dispersion coefficient }\left(\mathrm{m}^{2} \mathrm{~s}^{-1}\right) \\
S_{L}= & \text { source/sink term representing the time rate of inflow heat } \\
& \text { exchange }\left({ }^{\circ} \mathrm{C} \mathrm{m}^{3} \mathrm{~s}^{-1}\right) \\
S= & \text { source/sink term representing the time rate of change of local } \\
& \text { external heat exchange }\left({ }^{\circ} \mathrm{C} \mathrm{m}^{3} \mathrm{~s}^{-1}\right) .
\end{aligned}
$$

The above thermal transport model tracks heat and water fluxes along the model domain. The magnitude and rate of change in water temperature will depend on meteorological conditions and hydraulics. The main sources of heat exchange at the water surface in the $S$ term are short-wave solar radiation, long-wave atmospheric radiation, and conduction of heat from the atmosphere to the water. The main sinks of heat exchange are long-wave radiation emitted by the water, evaporation, and conduction from the water to the atmosphere. Heat exchange at the sediment-water interface is via conduction. The schematic of sources and sinks of heat at the air- and sediment-water interfaces is shown in Figure 3.

Figure 3. Sources and sinks of heat energy at the atmospheric and sediment interfaces (Deas and Lowney 2000).

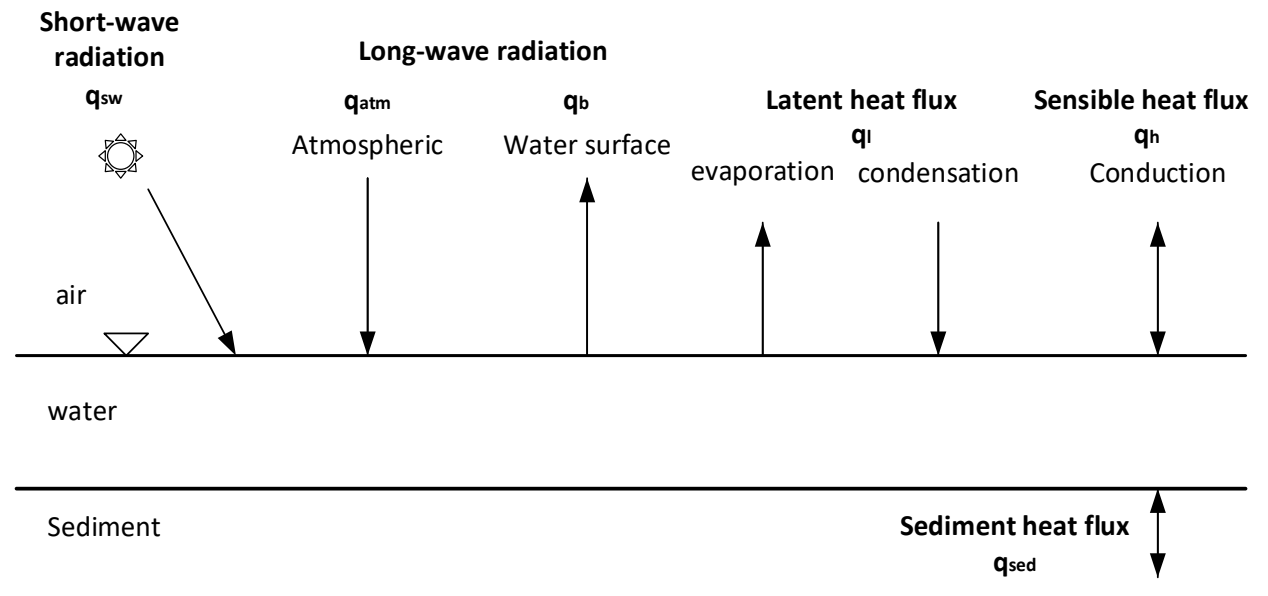

Units of heat flux $\left(\mathrm{W} \mathrm{m}^{-2}\right)$ are used to describe heat exchange at the airwater and sediment-water interfaces. The sign convention used herein is positive (+) for heat entering the water column, and negative (-) for heat leaving the water column. Net heat flux $\left(q_{n e t}\right)$ for the water column is

$$
q_{\text {net }}=q_{s w}+q_{a t m}-q_{b} \pm q_{h} \pm q_{l} \pm q_{\text {sed }}
$$

where 


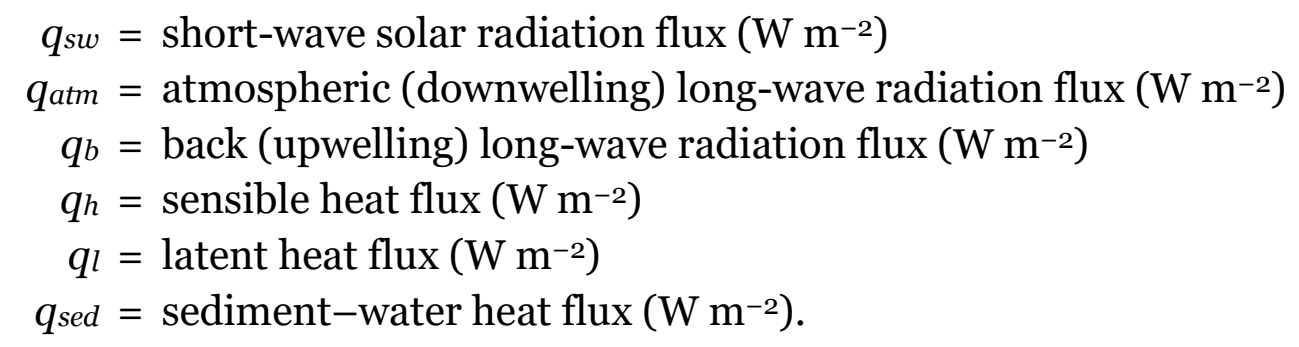

Each of the heat fluxes in equation 3.2 can be computed from userspecified meteorological data from the HEC-RAS user interface. Heat and temperature are related by the specific heat of water. The following equation describes the change in water temperature due to a change in net heat flux ( $\left.q_{\text {net }}\right)$

$$
\rho_{w} C_{p w} \frac{\partial T_{w}}{\partial t}=\frac{A_{s}}{V} q_{n e t}
$$

where

$$
\begin{aligned}
T_{w} & =\text { water temperature }\left({ }^{\circ} \mathrm{C}\right) \\
\rho_{w} & =\text { density of water }\left(\mathrm{kg} \mathrm{m}^{-3}\right) \\
C_{p w} & =\text { specific heat capacity of water }\left(\mathrm{J} \mathrm{kg}^{-1}{ }^{\circ} \mathrm{C}^{-1}\right) \\
A_{s} & =\text { surface area of the water column cell }\left(\mathrm{m}^{2}\right) \\
q_{\text {net }} & =\text { net heat flux at }\left(\mathrm{W} \mathrm{m}^{-2}\right) .
\end{aligned}
$$

The density of water is dependent on the dissolved and suspended matter as well as the temperature of the water. The HEC-RAS water temperature model does not account for ice. Therefore, model results for winter conditions should be viewed with caution, and recognize that results do not reflect observed conditions.

The heat transport equation 3.1 is solved in two steps. In the first step, a source/sink term $(S)$ is computed from the net heat flux. The source/sink value includes the effects of local heat change in a cell volume. In the second step, the effects of longitudinal transport in equation 3.1 are computed. For reasons of accuracy, efficiency, and stability, equation 3.1 is solved using the Quadratic Upstream Interpolation for Convective Kinematics with Estimated Streaming Terms--Universal Limiter for Transient Interpolation Modeling of Advective Transport Equation (QUICKEST-ULTIMATE) explicit numerical scheme. The QUICKESTULTIMATE form of the 1-D water quality transport solved in HEC-RAS (HEC 2016) is: 
$V^{n+1} C^{n+1}=V^{n} C^{n}+\Delta t\left(Q_{u p} C_{u p}^{*}-Q_{d n} C_{d n}^{*}+D_{d n} A_{d n} \frac{\partial C^{*}}{\partial x_{d n}}-D_{u p} A_{u p} \frac{\partial C^{*}}{\partial x_{u p}}\right)+\Delta t\left(S_{L}+S\right)$

where

$$
\begin{aligned}
C^{n+1}= & \text { concentration of a constituent at present time step }\left(\mathrm{g} \mathrm{m}^{-3}\right) \\
C^{n}= & \text { concentration of a constituent at previous time step }\left(\mathrm{g} \mathrm{m}^{-3}\right) \\
C_{u p^{*}=} & \text { QUICKEST concentration of a constituent at upstream cell } \\
& \text { face }\left(\mathrm{g} \mathrm{m}^{-3}\right) \\
\frac{\partial C^{*}}{\partial x} u p= & \text { QUICKEST derivative of a constituent at upstream cell face }(\mathrm{g} \\
& \left.\mathrm{m}^{-4}\right) \\
C_{d n}{ }^{*}= & \text { QUICKEST concentration of a constituent at downstream cell } \\
& \text { face }\left(\mathrm{g} \mathrm{m}^{-3}\right) \\
\frac{\partial C^{*}}{\partial x} d n= & \text { QUICKEST derivative of a constituent at downstream cells } \\
& \text { face }\left(\mathrm{g} \mathrm{m}^{-4}\right) \\
D_{u p}= & \text { upstream face dispersion coefficient }\left(\mathrm{m}^{2} \mathrm{~s}^{-1}\right) \\
V^{n+1}= & \text { volume of the computational cell at present time step }\left(\mathrm{m}^{3}\right) \\
V^{n}= & \text { volume of the computational cell at previous time step }\left(\mathrm{m}^{3}\right) \\
Q_{u p}= & \text { upstream face flow }\left(\mathrm{m}^{3} \mathrm{~s}^{-1}\right) \\
A_{u p}= & \text { upstream face cross sectional area }\left(\mathrm{m}^{2}\right) \\
Q_{d n}= & \text { downstream face flow rate }\left(\mathrm{m}^{3} \mathrm{~s}^{-1}\right) \\
A_{d n}= & \text { downstream face cross sectional area }\left(\mathrm{m}^{2}\right) .
\end{aligned}
$$

The above equation in HEC-RAS is used for solving all water quality constituents including water temperature $\left(T_{w}\right)$. $C$ will be substituted by $T_{w}$ for water temperature. Leonard $(1979,1991)$ provides details of QUICKEST- ULTIMATE formulae for solving unsteady flows on a nonuniform grid. The water quality model's time step is dynamically recalculated and adjusted in HEC-RAS so that subsequent Courant and Peclet constraints are automatically met. This differs from the flow model where the user must specify the time step (HEC 2016).

$$
\begin{gathered}
C_{u s}=u_{u s} \frac{\Delta t}{\Delta x} \leq 0.9 \\
\alpha_{u s}=D_{u s} \frac{\Delta t}{\Delta x^{2}} \leq 0.4
\end{gathered}
$$

where 


$$
\begin{aligned}
C_{u s} & =\text { Courant number } \\
u_{u s} & =\text { velocity at water quality cell face }\left(\mathrm{m} \mathrm{s}^{-1}\right) \\
\alpha_{u s} & =\text { local Peclet number } \\
D_{u s} & =\text { dispersion coefficient at water quality cell face }\left(\mathrm{m}^{2} \mathrm{~s}^{-1}\right)
\end{aligned}
$$

The Courant and Peclet numbers are cross section face properties. Both constraints can force a short time step if water quality cells are small. Therefore, small water quality cells within the model domain should be avoided.

The numerical solution of equation 3.4 requires initial and boundary conditions for simulated water quality constituents. In this study, the initial condition is the water temperature profile along the modeled river domain at the beginning of the simulation. Water temperatures for all inflow entering the modeled domain must be provided to the model. The upstream boundary condition is the water temperature at the upstream end of the domain during the period of simulation.

\subsection{Water temperature model input requirements}

The water temperature simulation in HEC-RAS uses the schematization that is already set up for the flow model. The HEC-RAS model computes water temperatures from a calibrated flow model. This means that the user only has to specify a limited amount of input data including:

- time frame of the water quality simulation

- definition of the water quality computational cells

- initial temperatures

- meteorological data

- temperatures at the inflow boundaries

- information about the numerical method and the time step.

When the water quality model is set up for the first time in HEC-RAS, water quality computational cells are initially established between cross sections. Water quality computational points are located exactly between cross section pairs. However, a single small water quality cell will force the model to choose a small time step in order to satisfy the stability conditions. The HEC-RAS allows users to combine small water quality cells together into larger ones and redefine the water quality computational cells. Meteorological data and inflow boundary conditions 
are primary model inputs for running a water quality model. They are time and space dependent and discussed below.

\subsubsection{Meteorological data}

Meteorological data influence water quality processes in aquatic systems. At least one full meteorological data set must be provided to run the HECRAS water temperature model. Hourly meteorological data are typically required for modeling water temperature due to large fluctuations in air temperature and solar radiation. A time series of the following parameters at a local meteorological station is required:

- Atmospheric pressure (mb)

- Air temperature $\left({ }^{\circ} \mathrm{C}\right)$

- Dew point $\left[{ }^{\circ} \mathrm{C}\right]$ or relative humidity (\%)

- Short wave radiation $\left(\mathrm{W} \mathrm{m}^{-2}\right)$

- Cloud cover [\%]

- Wind speed $\left(\mathrm{m} \mathrm{s}^{-1}\right)$

Meteorological data should be determined from the nearest recording meteorological station that is close to the river water surface elevation.

\subsubsection{Water temperature boundaries}

Complete sets of temperature data at the appropriate time intervals are required for all low flow or high flow conditions used for the model set up and calibration. Hourly, or at least daily, average inflow temperatures on major branch and tributary inflows are needed for all flow boundaries. Obtaining usable long-term stream water temperature records is not as easy as might be assumed. Water temperature records of many streams throughout the United States are available from the USGS web site. A major problem, however, is that stream temperature records frequently lack continuity over a whole year. The water temperature to be used as inflow boundary conditions for a long-term simulation is often not available and must be estimated. In this study, observed water temperature data for many boundaries is limited and of questionable quality. Historical water temperature data for several major tributaries in each model were not available, thus, they were substituted with observed data from other nearby monitoring stations. Observed water temperatures in many stations were monthly based, they were interpolated internally to the model computation time step to provide required data. This deficiency in observed data contributes to model error and uncertainty. 


\section{Missouri River HEC-RAS Water Temperature Models}

This chapter describes the HEC-RAS water temperature model development and calibration for the five modeled reaches of the Missouri River. The Fort Peck Dam to Garrison Dam and Fort Randall Dam to Gavins Point Dam reaches were only set up and calibrated for approximately two years $(2011$ - 2012). The HEC-RAS water temperature model results were not used in the current ManPlan and EIS nalysis. The reaches for Garrison Dam to Oahe Dam, Gavins Point Dam to Rulo, and Rulo to the mouth of the Missouri River were set up and ran for an 18-year simulation period (1995 - 2012). Model results from the latter three river reaches were used for conducting the ManPlan and EIS analysis.

\subsection{Meteorological data}

In this study, historical meteorological data were obtained from USAFETAC in Asheville, NC and the USEPA website. Hourly meteorological data were processed and compiled into one Hydrologic Engineering Center-Data Storage System (HEC-DSS) file (MoRmet.dss) for 14 meteorological stations along the main stem Missouri River. Figure 4 shows the spatial distribution of meteorological stations along the Missouri River used in the HEC-RAS temperature models. Table 1 lists the 14 meteorological stations and their locations and elevations. Each station includes the following five parameters: ATEM (air temperature), DEWP (dew point), SOLR (solar radiation/short wave radiation), CLOU (cloud cover), and WIND (wind speed). These parameters are included in the HEC-DSS file (MoRmet.dss), and their data records cover the period from $1975-2013$ at hourly intervals. Atmospheric pressure data was not available from USAFETAC and was calculated based on the elevation of meteorological stations specified in the model. 
Figure 4. Distribution of meteorological stations used in the Missouri River HEC-RAS models.

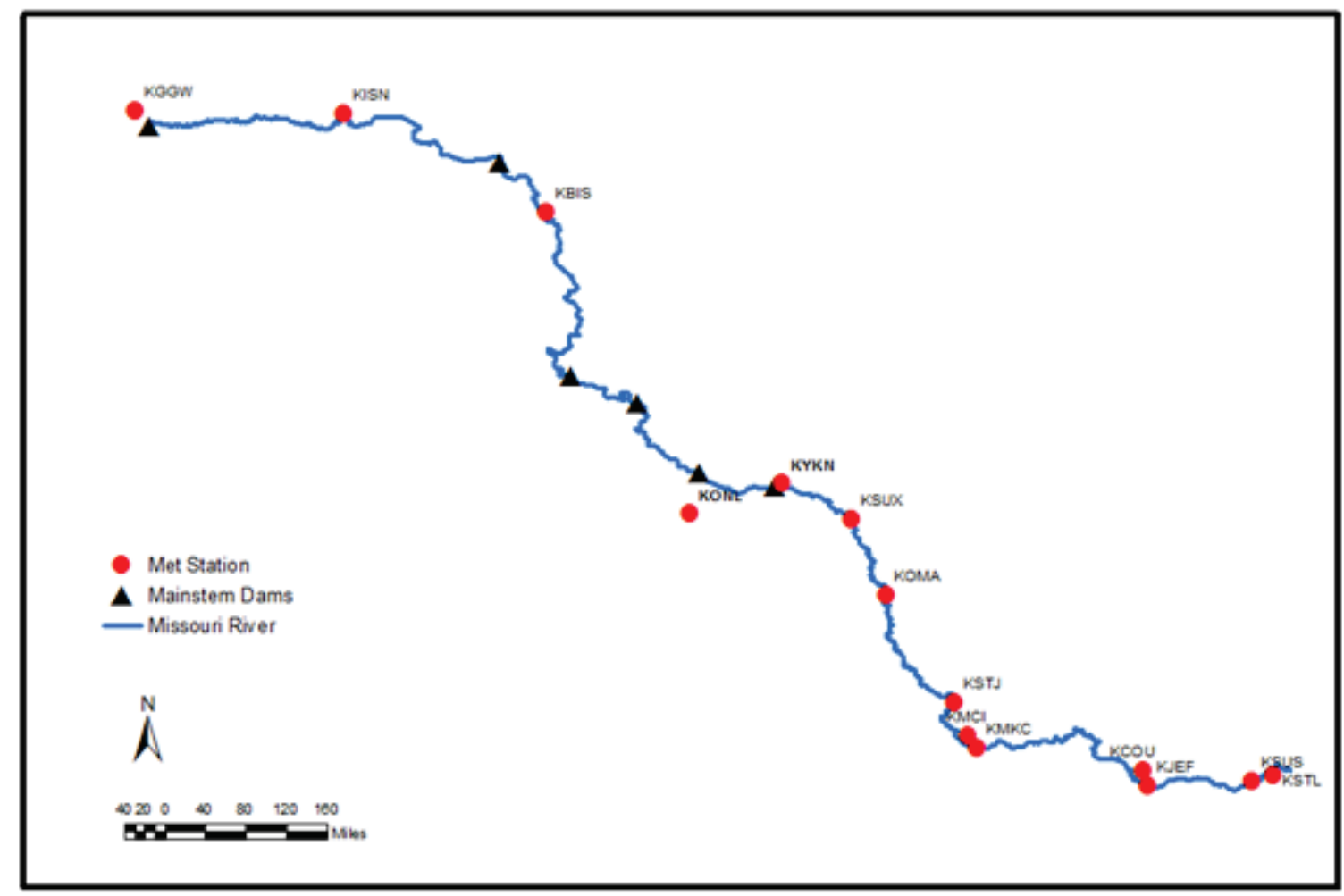


Table 1. Meteorological stations along the Missouri river and their locations and elevations.

\begin{tabular}{|c|c|c|c|c|c|}
\hline $\begin{array}{l}\text { USAFETA } \\
\text { C ID }\end{array}$ & BASINS ID & Station Location & Latitude & Longitude & $\begin{array}{l}\text { Elevation } \\
\text { (ft) }\end{array}$ \\
\hline KGGW & MT243558 & WOKAL FLD GLASGOW INTL, MT & 48.2125 & -106.61472 & 2296 \\
\hline KISN & ND329425 & SLOULIN FLD INTL, ND & 48.17793 & 103.64234 & 1982 \\
\hline KBIS & ND320819 & BISMARCK MUNI, ND & 46.77273 & -100.74573 & 1661 \\
\hline KONL & $\mathrm{n} / \mathrm{a}$ & $\begin{array}{l}\text { ONeillMuni John L Baker FLD, } \\
\text { NE }\end{array}$ & 42.46989 & -98.6881 & 2031 \\
\hline KYKN & SD726525 & Chan Gurney Muni, SD & 42.91669 & -97.3859 & 1306 \\
\hline KSUX & IA137708 & Sioux City AP, IA & 42.4026 & 96.384367 & 1098 \\
\hline KOMA & NE256255 & Omaha Eppley Airfield, NE & 41.30317 & 95.894069 & 984 \\
\hline KSTJ & M0237435 & Kansas City Intl AP, MO & 39.77194 & 94.909706 & 826 \\
\hline $\mathrm{KMCl}$ & M0234358 & St Louis Lambert Intl, MO & 39.29761 & -94.713905 & 1026 \\
\hline KMKC & M02343591 & St Joseph Rosecrans AP, MO & 39.12325 & -94.59275 & 759 \\
\hline $\mathrm{KCOU}$ & M0231791 & $\begin{array}{c}\text { Kansas City Charles Wheeler } \\
\text { Downtown AP, MO }\end{array}$ & 38.81809 & -92.219631 & 889 \\
\hline KJEF & M0724458 & $\begin{array}{c}\text { St Louis Spirit of St Louis AP, } \\
\text { MO }\end{array}$ & 38.59118 & -92.156144 & 549 \\
\hline KSUS & M0724345 & Jefferson City MEM, MO & 38.66212 & 90.652044 & 463 \\
\hline KSTL & M0237455 & Columbia Regional AP, MO & 38.74717 & $\begin{array}{c}- \\
90.361389\end{array}$ & 605 \\
\hline
\end{tabular}

${ }^{1}$ SOLR, CLOU, DEWP, WIND are missing from 1/1/2007 - 12/31/2009. They are substituted with corresponding data from MO234358 station.

The HEC-RAS temperature model requires meteorological data to be stored in HEC-DSS with a constant time interval (hourly in this case). There were often gaps in source data obtained from USAFETAC and the National Weather Service (NWS). Sometimes the data gaps were small, less than a day, and sometimes the data gaps were large, several days or months. For example, Figure 5 shows some of the gaps in hourly solar radiation and air temperature data at KOMA, NE. 
Figure 5. Data gaps of observed hourly (a) solar radiation and (b) air temperature at KOMA, NE.
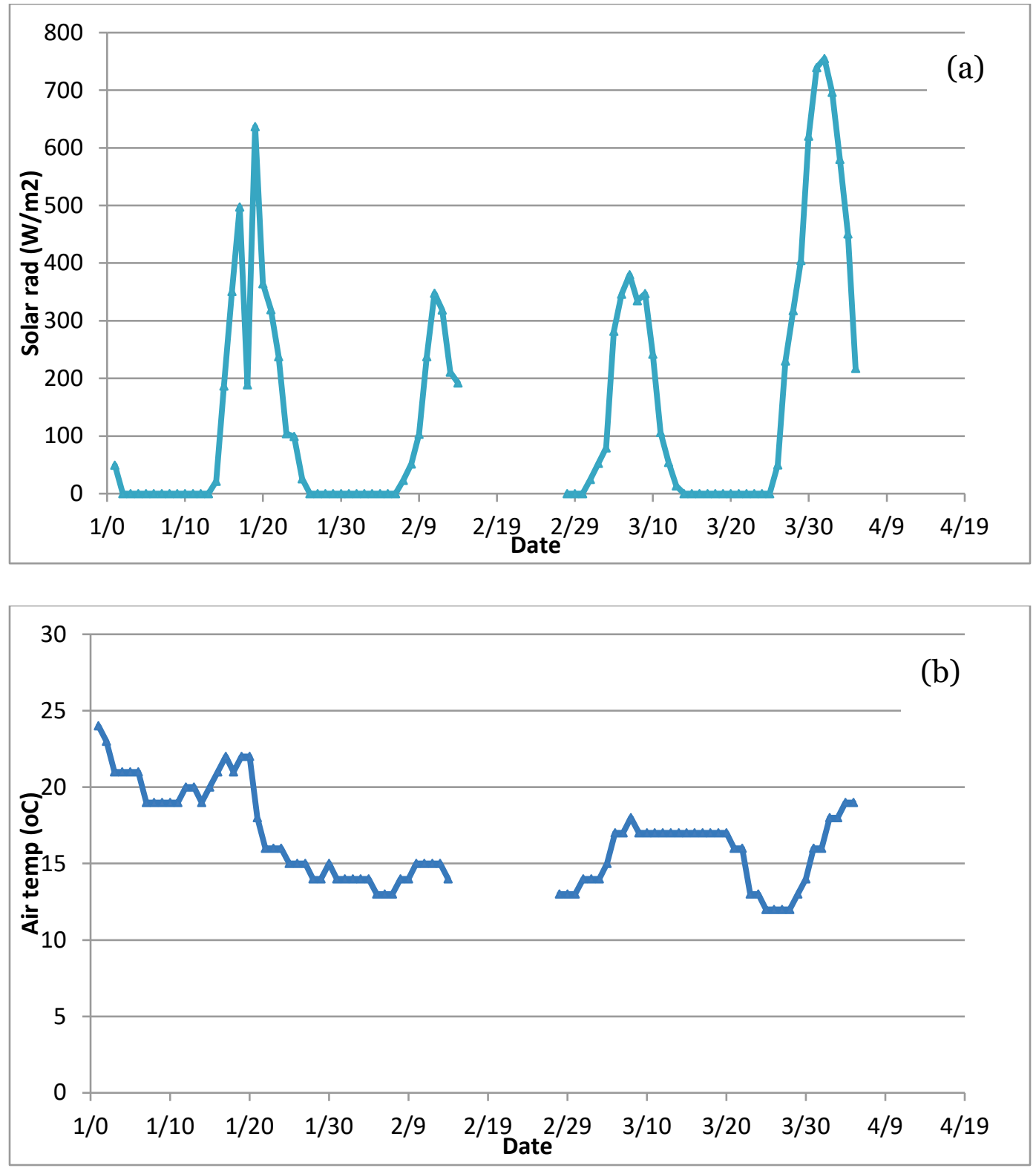

All gaps in meteorological data obtained from the above stations were linearly interpolated in HEC-DSS in order to use them as model inputs. Thus, the data gaps were filled with a straight line between the two bounding values. All meteorological data (after filling gaps) were compiled into one single HEC-DSS file (MoRmet.dss). For example, Figure 6 shows the time series plot of hourly air temperature at the Columbia Regional AP, MO station. 
Figure 6. Hourly air temperature at KOMA, NE.

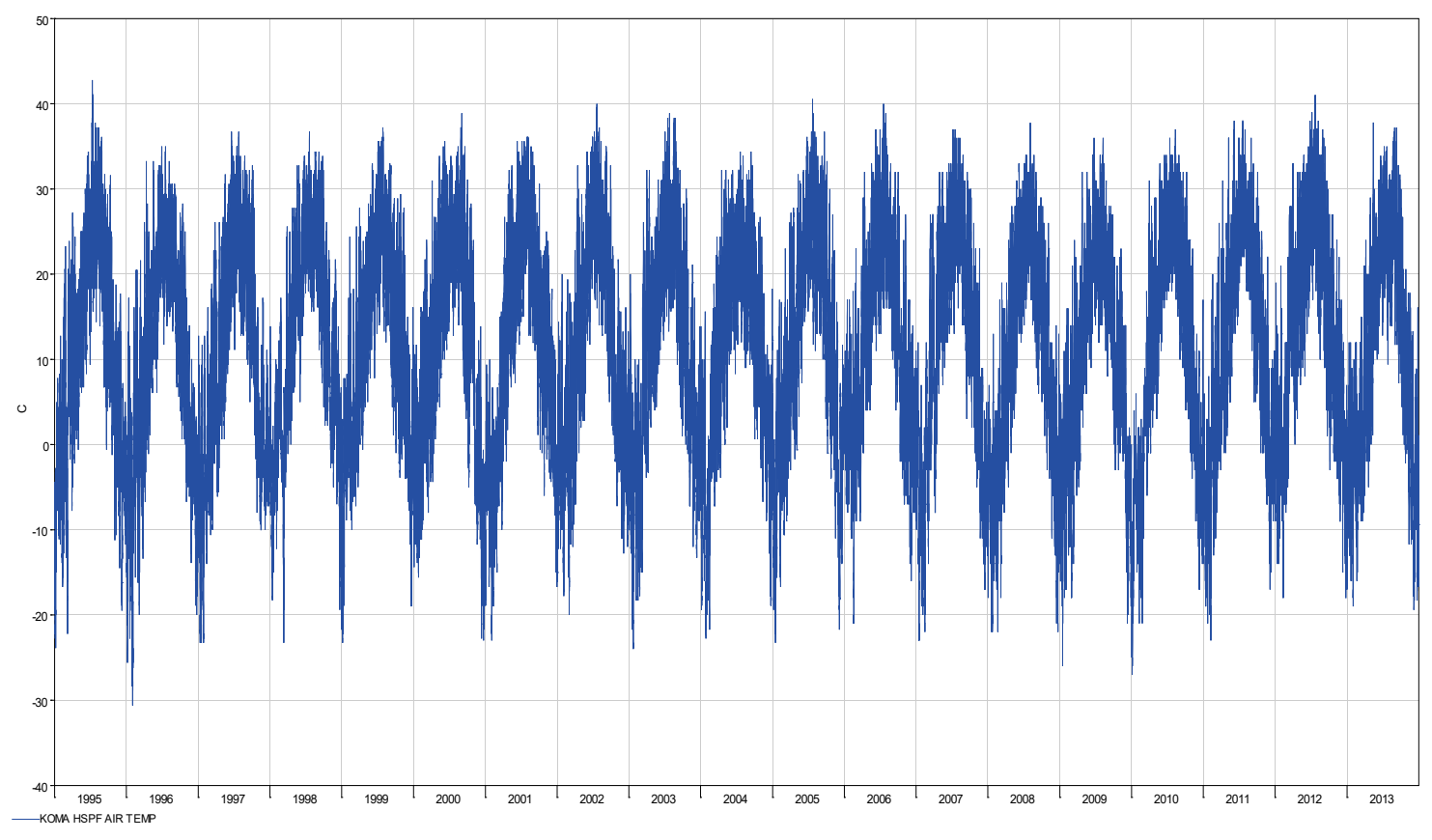

\subsection{Water temperature boundary conditions}

As described in the district report (USACE 2015), major tributaries discharging into the Missouri River were simulated in each HEC-RAS model. Minor tributaries were included as lateral inflow to the model. Numerous ungaged inflows were also included in the HEC-RAS models. Flow discharging into the main stem Missouri River from point sources was taken into account as part of ungagged flow.

In this study, the primary source for observed water temperature data was the USGS website. USACE Omaha and Kansas City Districts also provided observed data collected for 2010 - 2014 (USACE 2014a). Overall, observed water temperature data for the Missouri River as well as major tributaries were limited for the simulation period from 1995 - 2012. After reviewing existing water quality data, water temperature measurements generally were taken only once a month during the summer season. Water temperature data at most of the water quality monitoring locations only covered a five-year period from 2009 - 2013. Some locations have a longer period of record for water temperature measurements. There were almost no observed data before 2009 for all inflow tributaries.

Due to limited observed data, water temperatures for all inflow boundaries were generated from other methods. A basin wide watershed model such 
as the Soil and Water Assessment Tool (SWAT) or the Hydrological Simulation Program-Fortran (HSPF) can be used to compute water temperatures for all inflow boundaries discharging into the Missouri River. However, a watershed model for the Missouri River basin did not exist. Development and calibration of a watershed model for the Missouri River basin was not feasible under this project due to limited resources (i.e., funding and time). Alternatively, the project team proposed an air water temperature regression relationship for computing water temperatures for all inflow boundaries discharging into the Missouri River. Under the scope of this project, all boundary conditions of water temperature required in the HEC-RAS models in support of conducting current ManPlan and EIS were computed from the regression relationships and fed into the model.

Many factors influence stream temperature. Air temperature has often been used as an independent variable in regression analysis of stream temperature because it can be viewed as a surrogate for the net heat exchange (Webb et al. 2003). Previous researchers have successfully developed and applied linear and non-linear regression relationships between air and stream temperatures. Table 2 provides a summary of airwater temperature regression relationships that have been used in the past.

Table 2. Summary of air and water temperature regression models for rivers and streams

\begin{tabular}{|c|c|c|c|}
\hline $\begin{array}{l}\text { Regression } \\
\text { type }\end{array}$ & Application region & Time scale & Reference \\
\hline \multirow{10}{*}{ Linear } & $\begin{array}{c}40 \text { groundwater-fed streams in } \mathrm{MN} \text {, } \\
\text { USA }\end{array}$ & Weekly & Krider et al. (2013) \\
\hline & Red deer river in Canada & Daily & $\begin{array}{c}\text { Saffran and Anderson } \\
(1997)\end{array}$ \\
\hline & 39 stream stations in MN, USA & $\begin{array}{l}\text { Daily, weekly, } \\
\text { monthly, yearly }\end{array}$ & Pilgrim et al. (1998) \\
\hline & 43 U.S. and international sites & Daily & Morrill et al. (2005) \\
\hline & USGS stations, USA & $\begin{array}{l}\text { Daily, weekly, } \\
\text { monthly, yearly }\end{array}$ & Erickson and Stefan (2000) \\
\hline & $\begin{array}{l}\text { A small catchment in north-central } \\
\text { Austria }\end{array}$ & Monthly, yearly & \multirow{2}{*}{ Webb and Nobilis (1997) } \\
\hline & $\begin{array}{c}11 \text { streams Mississippi River basin, } \\
\text { USA }\end{array}$ & Daily, weekly & \\
\hline & Several rivers in UK & Monthly, yearly & $\begin{array}{c}\text { Stefan and Preud'homme } \\
\text { (1993) }\end{array}$ \\
\hline & 4 chalk streams in UK & Monthly & Smith (1981) \\
\hline & A Devon river system in UK & $\begin{array}{l}\text { Hourly, daily, } \\
\text { weekly }\end{array}$ & Mackey and Berrie (1991) \\
\hline
\end{tabular}




\begin{tabular}{|c|c|c|c|}
\hline $\begin{array}{c}\text { Regression } \\
\text { type }\end{array}$ & Application region & Time scale & Reference \\
\hline \multirow{7}{*}{ Non-linear } & River Drava, Croatia & Daily & Webb et al. (2003) \\
\cline { 2 - 4 } & 8 Alabama Rivers, USA & Hourly & $\begin{array}{c}\text { Rabi et al. (2015) } \\
\text { Chen G. and Fang X. (2015) }\end{array}$ \\
\cline { 2 - 4 } & Large river basins all over the world & Daily & Van Vliet et al. (2012) \\
\cline { 2 - 4 } & 43 U.S. and international sites & $\begin{array}{c}\text { Hourly, daily, } \\
\text { weekly }\end{array}$ & Morrill et al. (2005) \\
\cline { 2 - 5 } & A Devon river system in UK & Hourly & Webb et al. (2003) \\
\cline { 2 - 5 } & 8 Alabama Rivers, USA & & Chen G. and Fang X. (2015) \\
\hline
\end{tabular}

Water temperature results from the HEC-RAS models for the Fort Peck Dam to Garrison Dam and Fort Randall Dam to Gavins Point Dam reaches were not required in conducting ManPlan and EIS. Therefore, only water temperatures from tributary boundaries included in the three reaches for Garrison Dam to Oahe Dam, Gavins Point Dam to Rulo, and Rulo to the mouth of the Missouri River were computed from daily air and water temperature regression relationships as explained in the next section.

\subsubsection{Regression relationship between air and water temperatures}

In this study, two air-temperature regression approaches were evaluated for use with the periodic water temperature measurements: (1) linear regression, and (2) nonlinear regression. The first step was to evaluate which regression method (linear or nonlinear) to use. These two regression approaches were evaluated using two data sets over a seven year period (2007 - 2013), where one includes fewer observed water temperature values, and the other includes more observed water temperature values. If there are multiple meteorological stations around a stream temperature monitoring station, the closest meteorological station was used in developing the regression relationships. The first data set includes water temperature in the main stem Missouri River at Kansas City, MO (USGS 0689300) and air temperature at station MO234359. The second data set includes water temperature from the Mississippi River at Grafton, IL (USGS 05587455) and air temperature at MO232591. This reach of the Mississippi River was simulated in the lower Missouri River HEC-RAS model. After choosing the better regression approach, the selected approach was applied to develop regressions for each inflow boundary using observed water temperature data from that boundary, if 
available, and the nearest meteorological station for observed air temperatures.

Stream temperatures fluctuate at time scales ranging from diurnal to seasonal. Previous research showed that weekly and monthly averages of stream temperature and air temperature are better correlated with each other than are daily values (Stefan and Preud'homme 1993; Pilgrim et al. 1998; Erickson and Stefan 2000). Therefore, a 3-12 day moving average (the same day plus the next 6 , and past 6 days for the 12-day moving average) of air temperatures were used in developing regression relationships in this study.

\subsubsection{Linear regression}

As listed in Table 2, a simple linear regression was used to estimate water temperature as a function of one or more independent variables. When air temperature is specified as the only independent variable, the general linear regression equation is written as

$$
T_{\mathrm{w}}(\mathrm{t})=a_{0}+a_{1} T_{a}(t)+\varepsilon(t)
$$

where

$$
\begin{aligned}
T_{a}= & \text { measured } 3-12 \text { day moving average air temperature for the } \\
& \text { day } t\left({ }^{\circ} \mathrm{C}\right) \\
T_{w}= & \text { measure (or predicted) daily water temperature }\left({ }^{\circ} \mathrm{C}\right) \\
a_{0} \square a_{1}= & \text { regression coefficients } \\
\varepsilon(t)= & \text { error term. }
\end{aligned}
$$

All temperatures in the above equation are in degree Centigrade. The model calibration and validation to determine the two parameters $a_{o}, a_{1}$ was performed by minimizing the root mean square error (RMSE) between estimated regressions and observed water temperatures. RMSE is defined as

$$
R M S E=\sqrt{\frac{1}{n} \sum_{i}\left(O V_{i}-M V_{i}\right)^{2}}
$$

where

$R M S E=$ root mean square error

$n=$ number of observations 


$$
\begin{aligned}
O V_{i} & =\text { observed value } \\
M V_{i} & =\text { model computed value }
\end{aligned}
$$

To evaluate the goodness of fit and model performance of various regression relationships, the coefficient of determination $\left(R^{2}\right)$ is used in addition to regression scatter plots of model predicted and observed data sets. $\mathrm{R}^{2}$ is calculated with the following formula,

$$
R^{2}=\frac{\left(\sum_{i}\left(O V_{i}-\overline{O V}\right)\left(M V_{i}-\overline{M V}\right)\right)^{2}}{\sum_{i}\left(O V_{i}-\overline{O V}\right)^{2} \sum_{i}\left(M V_{i}-\overline{M V}\right)^{2}}
$$

where

$$
\begin{aligned}
\overline{O V} & =\text { mean of observed values } \\
\overline{M V} & =\text { mean of model computed values. }
\end{aligned}
$$

$R^{2}$ is an indicator of the strength of the linear relationship between the predicted and observed values. The $\mathrm{R}^{2}$ values can vary from zero - one, which describes how much of the observed dispersion the model explains. A value of zero means no correlation at all; whereas a value of one means that the dispersion of the model is equal to that of the observation, which indicates a perfect fit.

Langan et al. (2001) indicated that the best fit between air and water temperature occurred in the summer. Stream temperatures during the summer seasons can be more accurately predicted from the linear regression relationship. Webb et al. (2003) also indicated that air and water temperatures are more strongly correlated when flows are below median levels.

First, the authors evaluated the linear regression relationship between observed water versus air temperatures. Figure 7 shows the scatter plot of observed water and air temperatures at USGS 0689300 with a linear regression relationship. Both visual comparison and statistics $\left(R^{2}\right)$ indicate that there is a strong linear co-relationship between water and air temperatures at this location. 
Figure 7. Scatter plot of observed water versus air temperatures at USGS 0689300.

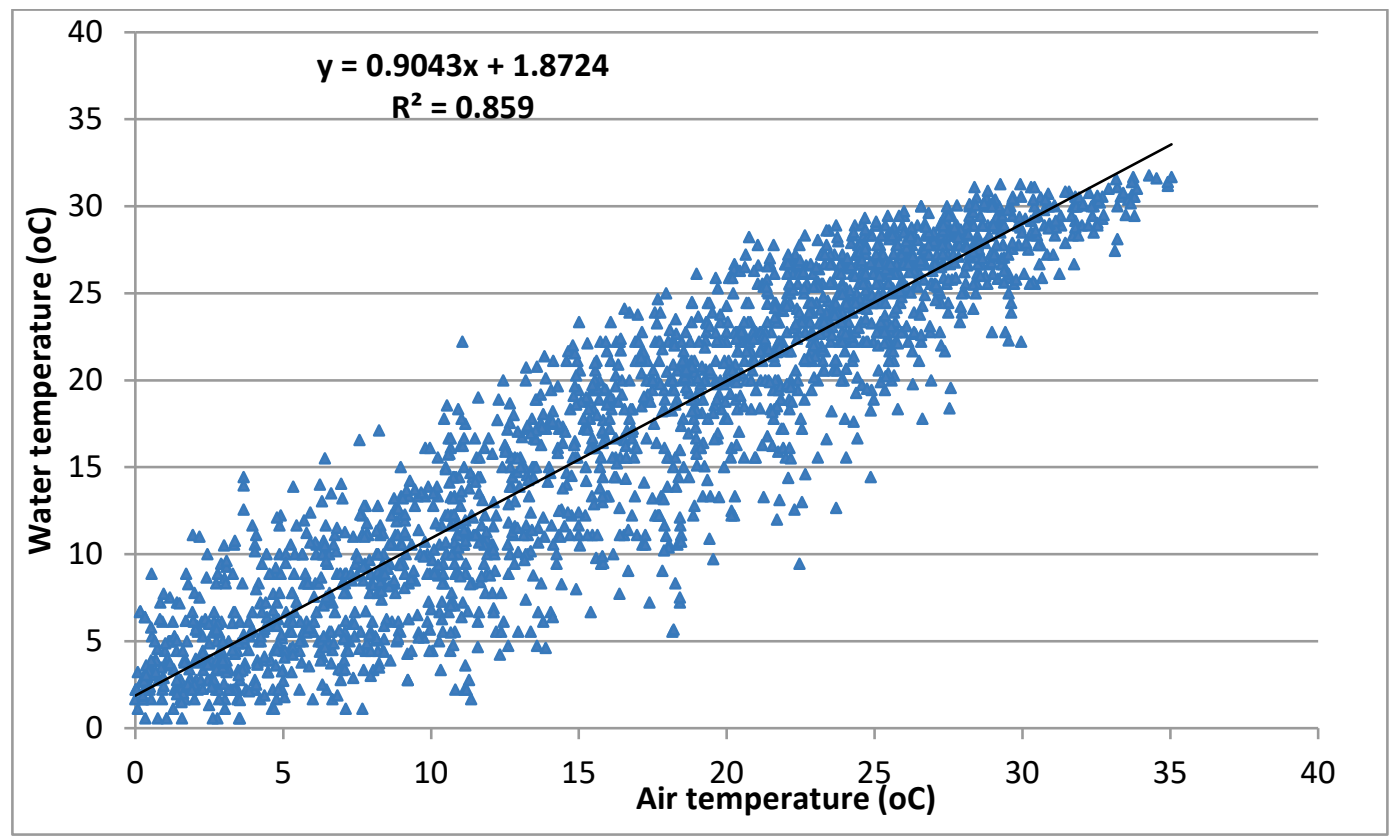

Seven year time series plot of observed and linear-regression-computed water temperatures with six day moving average air temperature at USGS o689300 is presented in Figure 8.

Figure 8. Observed vs. linear-regression-computed water temperatures at USGS 0689300.

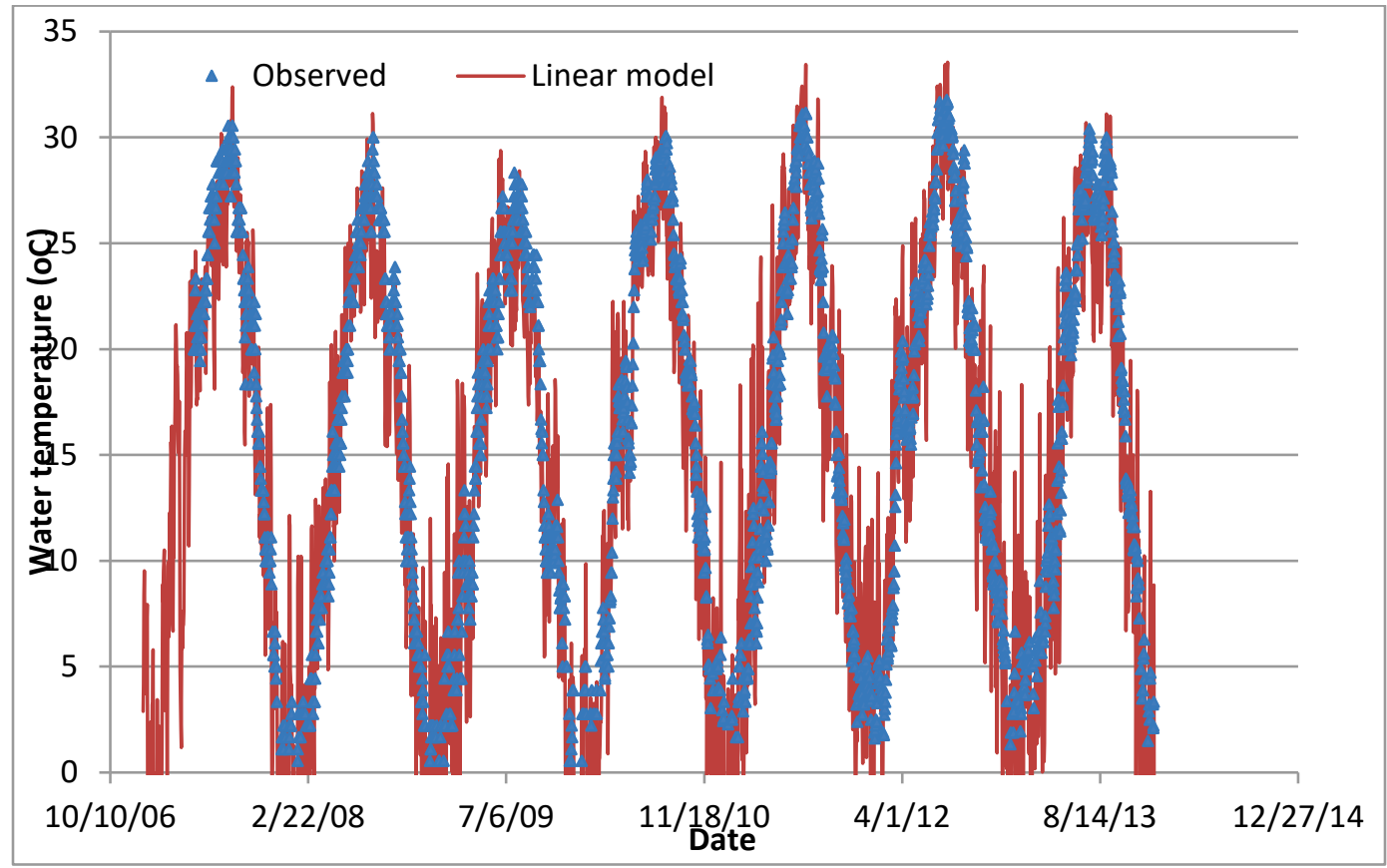


The second data set includes water temperature from the Mississippi River at Grafton, IL (USGS 05587455) and air temperature at MO232591.

Figure 9 shows the scatter plot of observed water and air temperatures at this location with a linear regression relationship. The linear corelationship between water and air temperatures is relatively weak.

Figure 9. Scatter plot of observed water versus air temperatures at USGS 05587455.

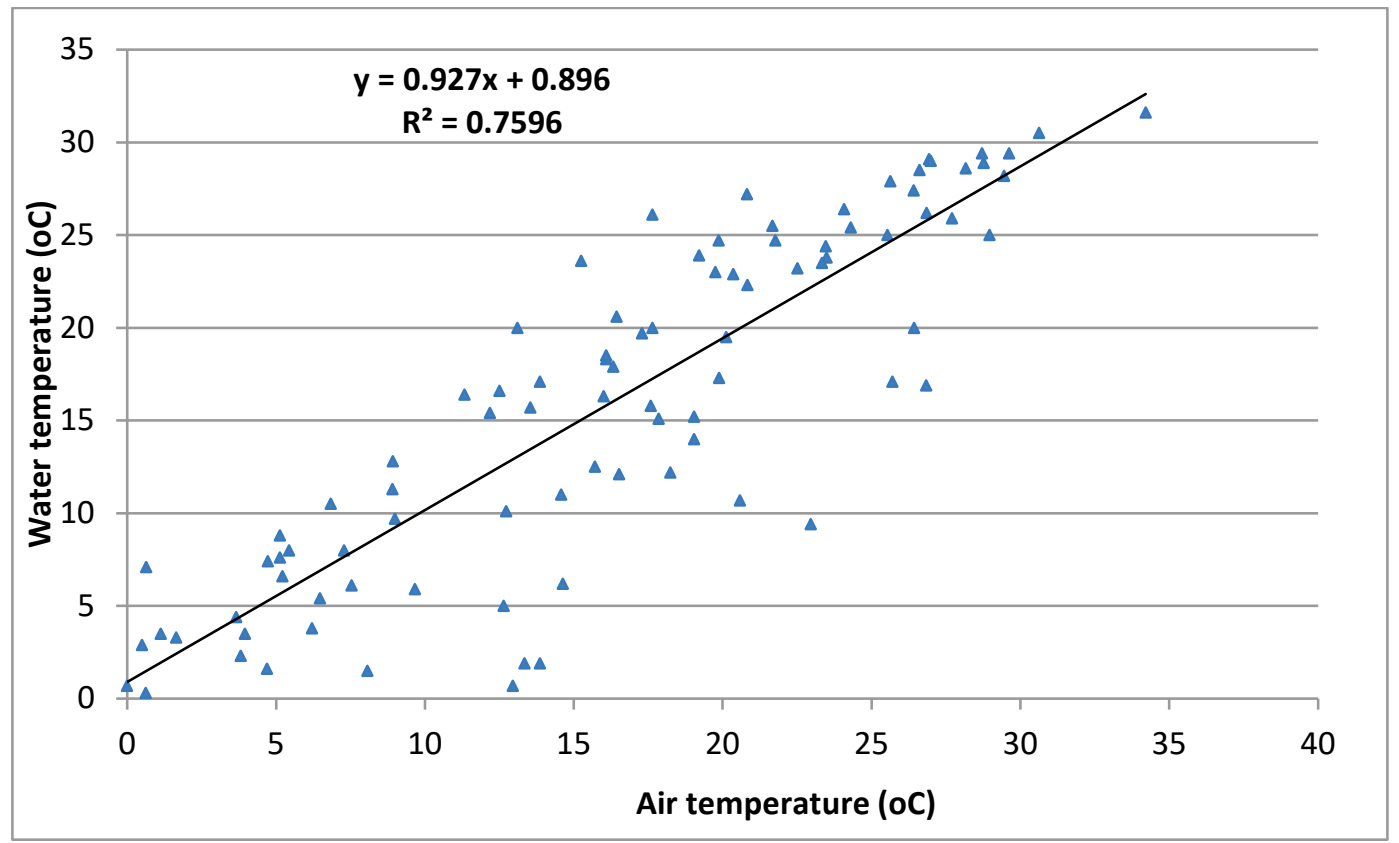

Seven year time series comparison of observed and linear-regressioncomputed water temperatures at USGS 05587455 is presented in Figure 10 . 
Figure 10. Observed vs. regression-computed water temperatures at USGS 05587455.

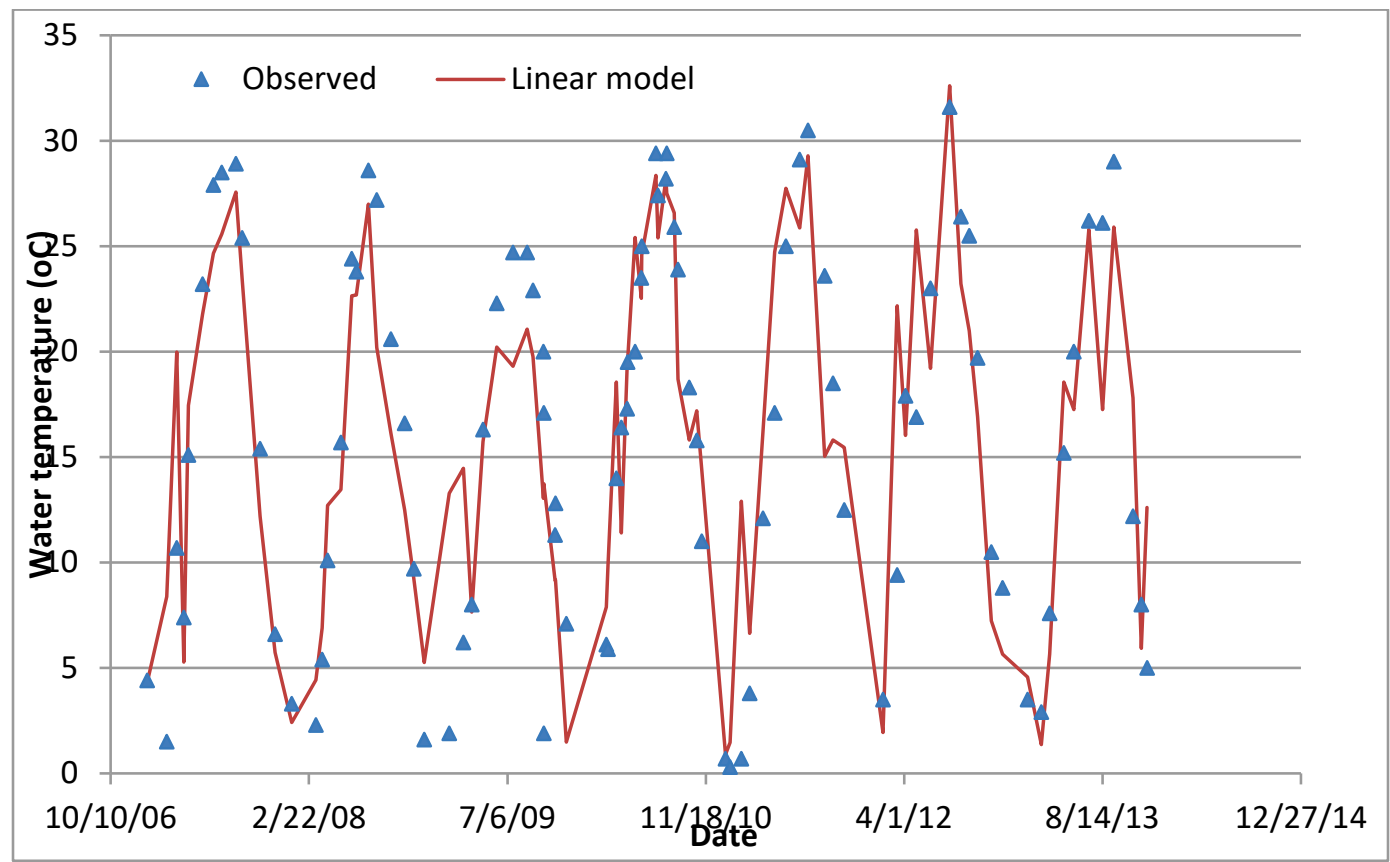

\subsubsection{Non-linear regression}

A significant non-linear relation between air and water temperatures was also observed at hourly, daily, or weekly intervals (Mohseni et al. 1998). Accordingly, an S-shaped logistic function to predict daily stream temperatures (using 3-12 day moving average air temperatures) at different locations in the U.S. was developed (Mohseni et al. 1998). This function is expressed as:

$$
T_{\mathrm{w}}=\mu+\frac{\alpha-\mu}{1+e^{\gamma\left(\beta-T_{a}\right)}}
$$

where

$$
\begin{aligned}
& a=\text { estimated maximum water temperature } \\
& \beta=\text { air temperature at the inflexion point } \\
& \mu=\text { estimated minimum water temperature } \\
& \gamma=\text { steepest slope of the logistic function. }
\end{aligned}
$$

The parameters $\mu, \gamma$, and $\beta$ are calculated iteratively to minimize RMSE.

The non-linear regression was also evaluated using two data sets (USGS gages 0689300 and 05587455) discussed above. Seven year time series comparison of observed and nonlinear regression estimated water 
temperatures for these two locations are presented in Figure 11 and Figure 12. Calibrated non-linear regression equations for USGS gages 0689300 and 05587455 are defined as follows:

$$
\begin{aligned}
& T_{\mathrm{w}}=-0.24328+\frac{33.7026+0.24328}{1+e^{0.12533\left(16.50901-T_{a}\right)}} \\
& T_{\mathrm{w}}=-1.02148+\frac{34.51232+1.02148}{1+e^{0.12318\left(17.25027-T_{a}\right)}}
\end{aligned}
$$

Figure 11. Observed vs regression computed water temperatures at USGS 0689300.

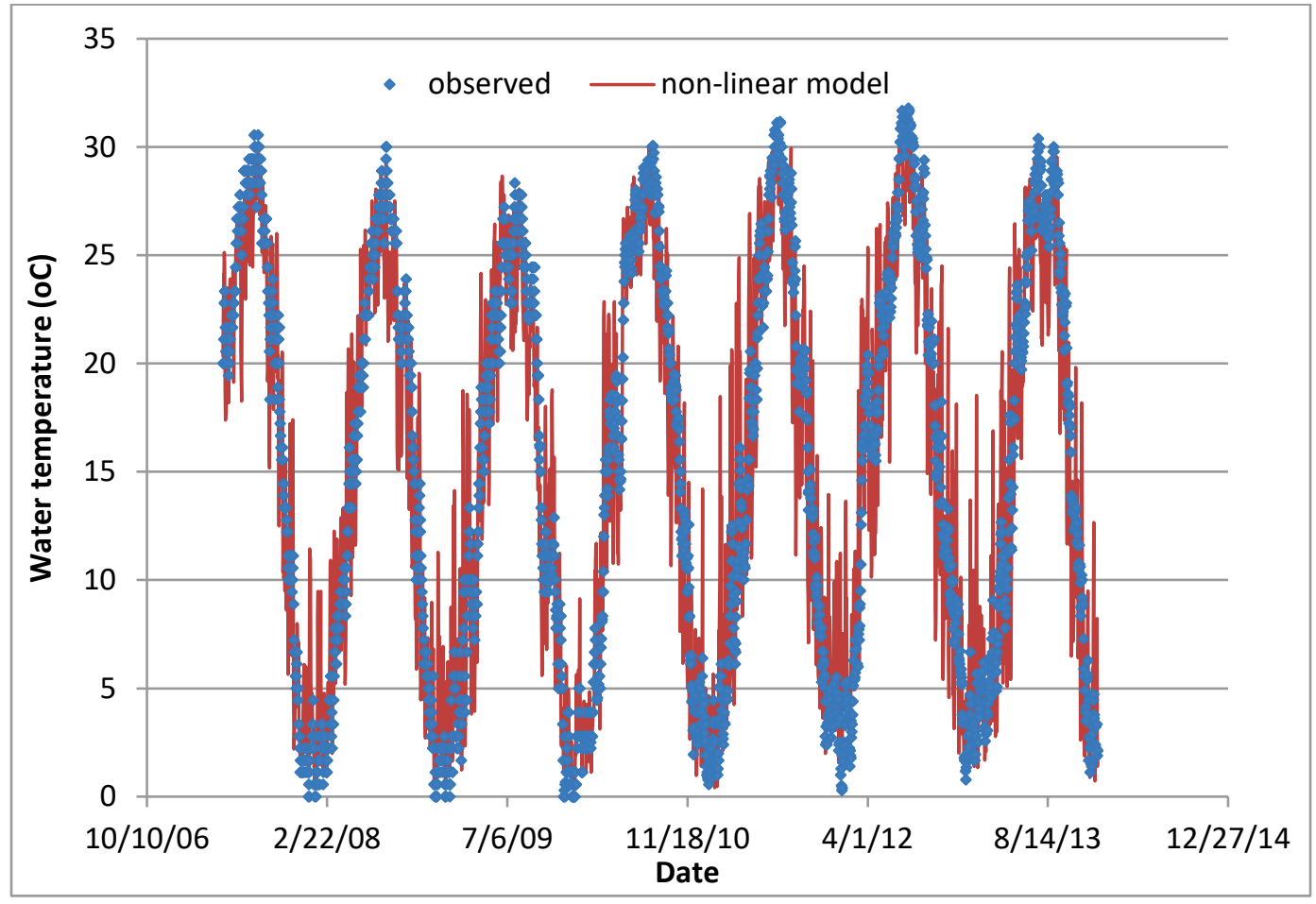


Figure 12. Observed and regression computed water temperatures at USGS 05587455.

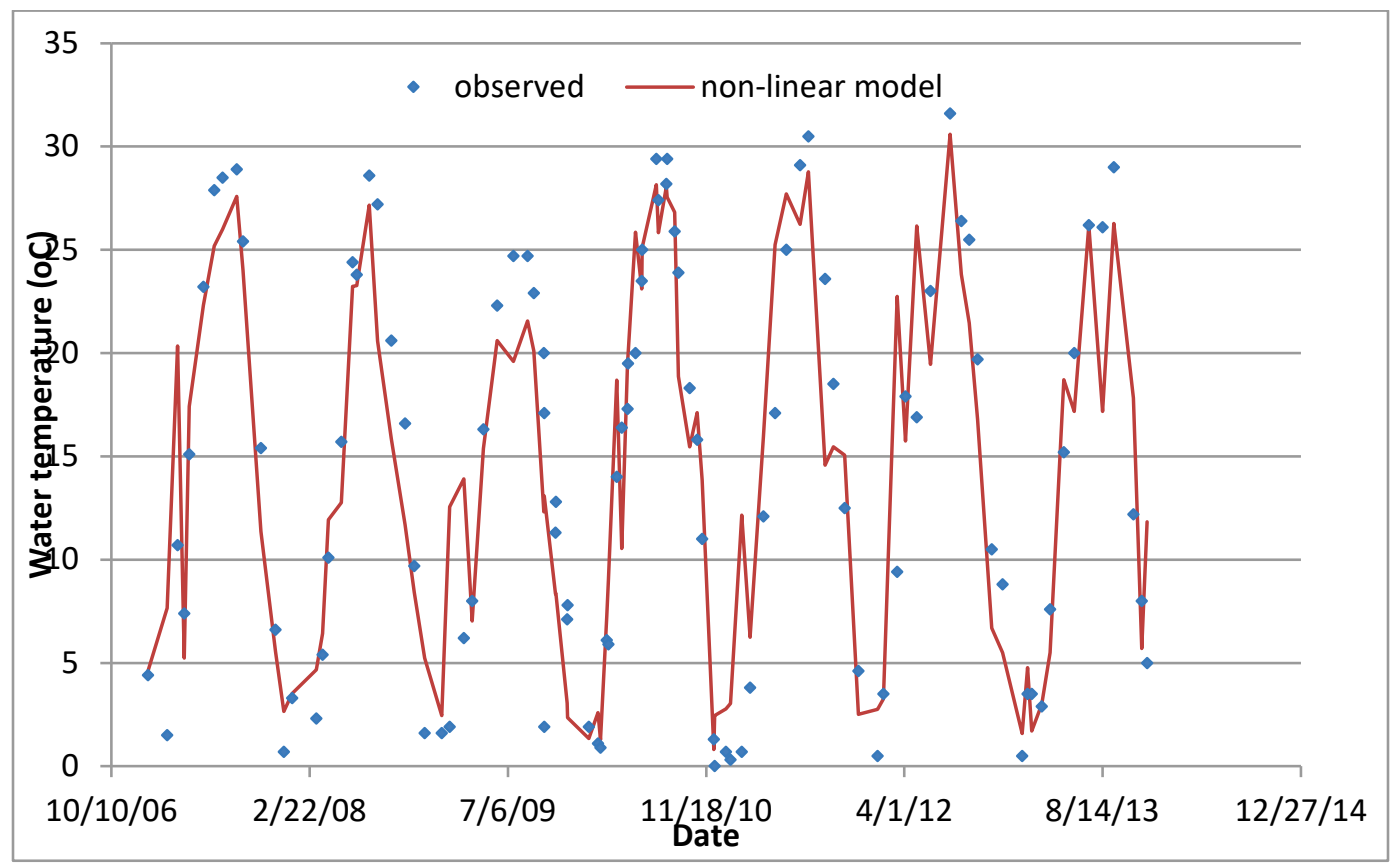

As shown in the above figures, nonlinear regression equations for both locations perform better than their linear regression equations when air temperatures are close to $\mathrm{O}^{\circ} \mathrm{C}$. The liner regression RMSE values for USGS gages 0689300 and 05587455 are 3.30 and 4.49. Their respective non-linear regression RMSE values are 3.087 and 4.258. Warmer temperatures, predicted using the two regression approaches discussed above, are pretty much the same for the two data sets. However, calibrating $\mu, \gamma$, and $\beta$ parameters included in the nonlinear regression is a challenge for multiple locations as well as long-term data sets (i.e., more than ten years). For efficiency, a piecewise linear regression was an adequate approach to explain the nonlinear relationship between water and air temperatures.

The piecewise linear regression equation for each location was developed as follows. Water temperatures were observed for a specific tributary and for a given day. All years with observed water temperature data were assembled together along with the day of the observation. A best-fit linear regression was developed using water temperature for that day and 3-12 day moving averages of previous air temperatures. RMSE and $\mathrm{R}^{2}$ values were used as statistic evaluators of the fitted regression relationship. The moving average of air temperatures that produced the best fit for the tributary and the associated regression equation was used to generate the daily water temperatures for the entire simulation period (1995-2012). 
Thus, a linear regression equation was developed for each inflow boundary, and these regression equations were used to generate daily water temperatures for all inflow boundaries throughout the year for the simulation period 1995-2012. These daily inflow water temperatures were then fed into the HEC-RAS models for the three reaches, Garrison Dam to Oahe Dam, Gavins Point Dam to Rulo, and Rulo to the mouth of the Missouri River.

\subsubsection{Application of the regression equations to compute water temperatures of inflowing tributaries}

As explained above, a series of linear regression equations were applied to compute daily stream temperatures of inflowing tributaries as a function of daily air temperatures. Figure 13 is a map of the water quality monitoring gages and meteorological stations used in the regression relationship for the Garrison Dam to Oahe Dam reach. Figure 14 is a map of the water quality monitoring gages and meteorological stations used for Gavins Point Dam to Rulo and Rulo to the mouth of the Missouri River reaches. Table 3 lists all water temperature boundaries computed from the regression relationships. Fifty-one boundary conditions of inflowing water temperatures were created for the three HEC-RAS water temperature models (Garrison Dam to Oahe Dam, Gavins Point Dam to Rulo, Rulo to the mouth of the Missouri River). Mean daily air temperatures using the regressions were computed from observed hourly data stored in the HEC-DSS file (MoRMet.dss). 
Figure 13. Water quality monitoring gages and correlated meteorological stations for the Garrison Dam to Oahe Dam reach.

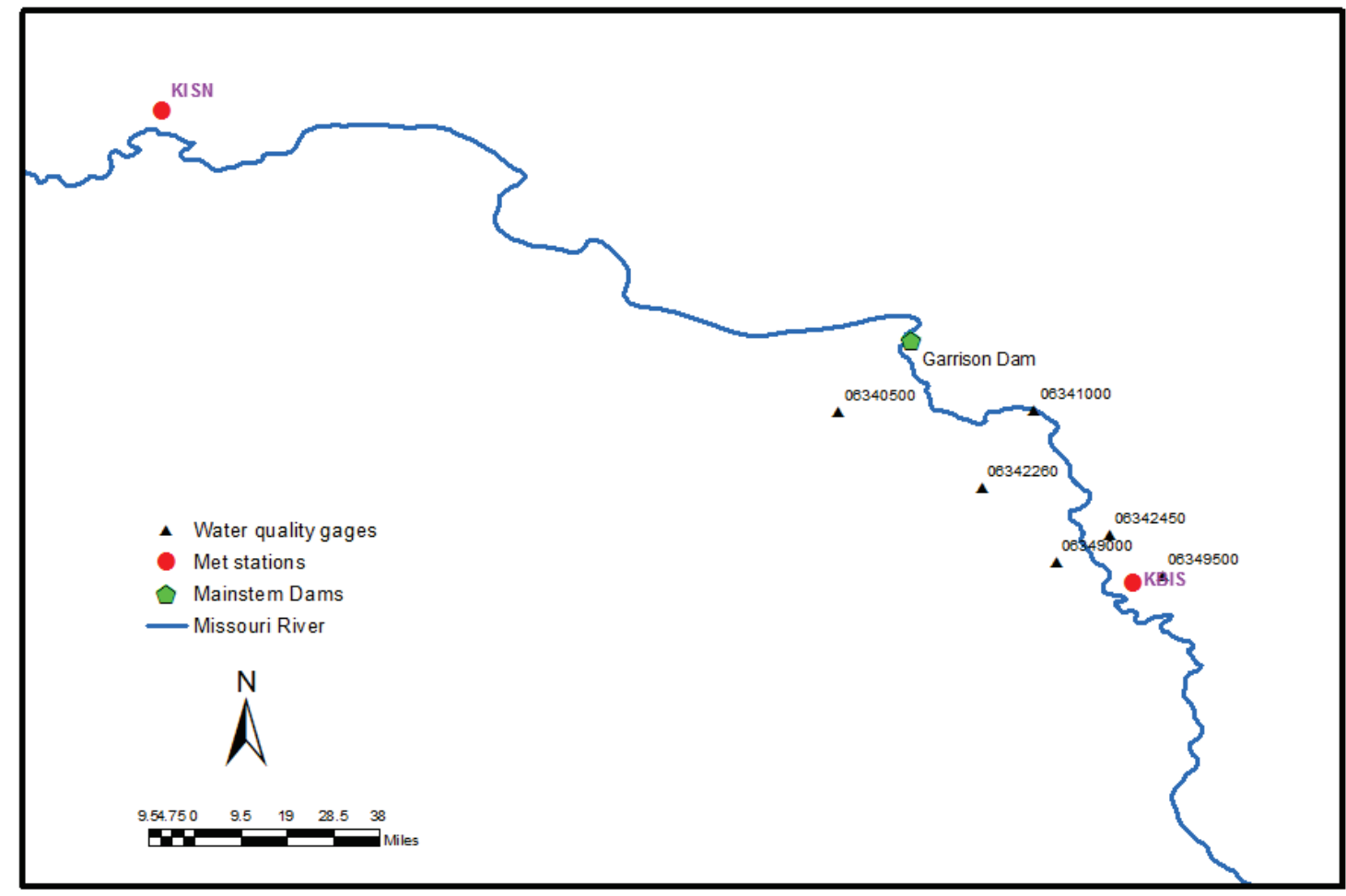

Figure 14. Water quality monitoring gages and correlated meteorological stations for the lower Missouri River from the Givens Point Dam to the mouth of the Missouri River.

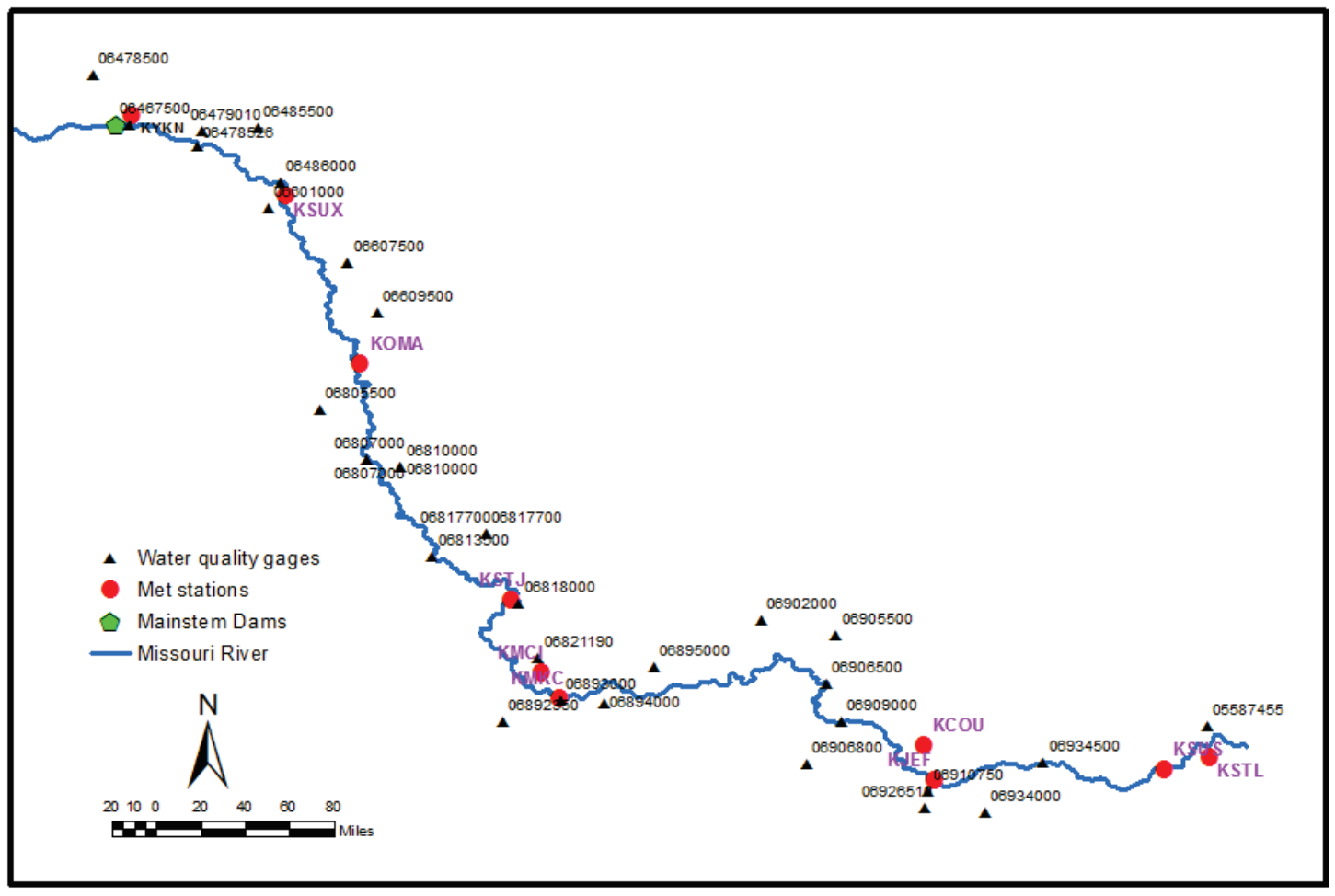


Table 3. Water temperature boundaries derived from water quality monitoring gages and meteorological stations.

\begin{tabular}{|c|c|c|c|c|c|}
\hline $\begin{array}{l}\text { Water } \\
\text { quality } \\
\text { Boundary* }\end{array}$ & $\begin{array}{l}\text { Water quality } \\
\text { gage }\end{array}$ & Water quality gage location & Record of observed data & $\begin{array}{l}\text { No of } \\
\text { samples }\end{array}$ & $\begin{array}{l}\text { Met } \\
\text { station }\end{array}$ \\
\hline \multicolumn{6}{|c|}{ Garrison Dam to Oahe Dam reach } \\
\hline $\mathrm{BC} 1$ & 06349500 & Apple Creek Nr Menoken, ND & $2 / 17 / 2000-11 / 7 / 2013$ & 67 & KBIS \\
\hline $\mathrm{BC} 2$ & 06349000 & Heart River Nr Mandan, ND & $3 / 7 / 2000-7 / 26 / 2012$ & 57 & KBIS \\
\hline BC3 & 06340500 & Knife River at Hazen, ND & $1 / 18 / 2000-7 / 24 / 2012$ & 56 & KBIS \\
\hline BC4 & 06349500 & Apple Creek Nr Menoken, ND & $2 / 17 / 2000-11 / 7 / 2013$ & 67 & KBIS \\
\hline BC5 & 06349500 & Apple Creek Nr Menoken, ND & $2 / 17 / 2000-11 / 7 / 2013$ & 67 & KBIS \\
\hline BC6 & 06342260 & $\begin{array}{l}\text { Square Butte Creek below } \\
\text { Center, ND }\end{array}$ & $2 / 23 / 2000-10 / 25 / 2013$ & 58 & KBIS \\
\hline $\mathrm{BC7}$ & 06342450 & Burnt Creek Nr Bismarck, ND & $2 / 26 / 2000-7 / 25 / 2012$ & 42 & KBIS \\
\hline BC8 & 06349500 & Apple Creek Nr Menoken, ND & $2 / 17 / 2000-11 / 7 / 2013$ & 67 & KBIS \\
\hline \multicolumn{6}{|c|}{ Gavins Point Dam to Rulo reach } \\
\hline $\mathrm{BC} 1$ & 06813500 & Missouri River at Rulo, NE & $1 / 4 / 2000-12 / 31 / 2013$ & 661 & KSTJ \\
\hline $\mathrm{BC} 2$ & 06485500 & Big Sioux River at Akron, IA & $1 / 5 / 2000-9 / 4 / 2013$ & 246 & KSUX \\
\hline BC3 & 06609500 & Boyer River at Logan, IA & $1 / 25 / 2000-12 / 17 / 2013$ & 145 & KOMA \\
\hline BC4 & 06478500 & James River near Scotland, SD & $1 / 4 / 2000-9 / 4 / 2013$ & 176 & KYKN \\
\hline BC5 & 06607500 & Little Sioux River near Turin, IA & $1 / 28 / 2000-12 / 18 / 2013$ & 132 & KOMA \\
\hline BC6 & 06467500 & Missouri River at Yankton SD & $10 / 1 / 2010-7 / 16 / 2013$ & 1000 & KYKN \\
\hline $\mathrm{BC} 7$ & 06478526 & Missouri River near Maskell NE & $7 / 16 / 2009-10 / 16 / 2013$ & 36 & KYKN \\
\hline $\mathrm{BC} 8$ & 06486000 & Missouri River at Sioux City, IA & $1 / 3 / 2000-12 / 2 / 2013$ & 871 & KYKN \\
\hline BC9 & 06486000 & Missouri River at Sioux City, IA & $1 / 3 / 2000-12 / 2 / 2013$ & 871 & KSUX \\
\hline BC10 & 06601200 & Missouri River at Decatur, NE & $5 / 28 / 2009-10 / 15 / 2013$ & 201 & KSUX \\
\hline BC11 & 06610000 & Omaha Creek at Homer, NE & $1 / 3 / 2000-12 / 28 / 2013$ & 1157 & KOMA \\
\hline BC12 & 06805500 & Platte River at Louisville NE & $1 / 21 / 2000-12 / 18 / 2013$ & 252 & KOMA \\
\hline $\mathrm{BC} 13$ & 06807000 & $\begin{array}{l}\text { Missouri River at Nebraska City, } \\
\text { NE }\end{array}$ & $1 / 3 / 2000-12 / 18 / 2013$ & 1453 & KOMA \\
\hline BC14 & 06810000 & $\begin{array}{l}\text { Nishnabotna River above } \\
\text { Hamburg, IA }\end{array}$ & $2 / 22 / 2000-12 / 16 / 2013$ & 135 & KOMA \\
\hline BC15 & 06817700 & $\begin{array}{l}\text { Nodaway River near Graham, } \\
\text { MO }\end{array}$ & $3 / 15 / 2000-10 / 22 / 2013$ & 91 & KSTJ \\
\hline BC16 & 06479010 & $\begin{array}{l}\text { Vermillion River near Vermillion } \\
\text { SD }\end{array}$ & $1 / 5 / 2000-9 / 4 / 2013$ & 183 & KYKN \\
\hline
\end{tabular}




\begin{tabular}{|c|c|c|c|c|c|}
\hline \multicolumn{6}{|c|}{ Rulo to the mouth of the Missouri River reach } \\
\hline BC1 & 06810000 & $\begin{array}{l}\text { Nishnabotna River above } \\
\text { Hamburg, IA }\end{array}$ & $7 / 16 / 2009-10 / 15 / 2013$ & 35 & KSTJ \\
\hline $\mathrm{BC} 2$ & 06906800 & Lamine River near Otterville, MO & $7 / 16 / 2009-10 / 16 / 2013$ & 36 & $\mathrm{KCOU}$ \\
\hline BC3 & 06910750 & $\begin{array}{l}\text { Moreau River near Jefferson City, } \\
\text { MO }\end{array}$ & $7 / 16 / 2009-10 / 15 / 2013$ & 35 & $\mathrm{KCOU}$ \\
\hline BC4 & 06934000 & $\begin{array}{l}\text { Gasconade River near Rich } \\
\text { Fountain, MO }\end{array}$ & $7 / 16 / 2009-10 / 17 / 2013$ & 33 & KJEF \\
\hline BC5 & 06902000 & Grand River near Sumner, MO & $7 / 16 / 2009-10 / 16 / 2013$ & 36 & KMKC \\
\hline BC6 & 06892350 & Kansas River, Desoto, KS & $5 / 17 / 2010-10 / 15 / 2013$ & 29 & KMKC \\
\hline BC7 & 06906800 & Lamine River near Otterville, MO & $7 / 16 / 2009-10 / 16 / 2013$ & 36 & KCOU \\
\hline $\mathrm{BC} 8$ & 06934500 & Missouri River at Hermann, MO & $6 / 13 / 2005-12 / 3 / 2013$ & 103 & KSTL \\
\hline BC9 & 06807000 & Missouri River, Nebraska City, NE & $1 / 10 / 2007-12 / 4 / 2013$ & 358 & KSTJ \\
\hline BC10 & 06818000 & Missouri River, St. Joseph, MO & $1 / 10 / 2009-10 / 16 / 2013$ & 358 & $\mathrm{KMCl}$ \\
\hline BC11 & 06893000 & Missouri River, Kansas City, MO & $1 / 3 / 2007-12 / 18 / 2013$ & 670 & KMKC \\
\hline $\mathrm{BC} 12$ & 06894000 & $\begin{array}{l}\text { Little Blue River near Lake City, } \\
\text { MO }\end{array}$ & $1 / 3 / 2007-12 / 18 / 2013$ & 670 & KMKC \\
\hline BC13 & 06895000 & $\begin{array}{l}\text { Crooked River near Richmond, } \\
\text { MO. }\end{array}$ & $1 / 3 / 2007-12 / 18 / 2013$ & 670 & KMKC \\
\hline BC14 & 06906500 & Missouri River at Glasgow, MO & $5 / 28 / 2009-10 / 15 / 2013$ & 201 & $\mathrm{KCOU}$ \\
\hline BC15 & 06900900 & Missouri River at Boonville, MO & $5 / 9 / 2007-12 / 30 / 2013$ & 2428 & KJEF \\
\hline BC16 & 06934500 & Missouri River at Hermann, MO & $6 / 13 / 2005-12 / 3 / 2013$ & 103 & KSUS \\
\hline BC17 & 06910750 & $\begin{array}{l}\text { Moreau River near Jefferson City, } \\
\text { MO }\end{array}$ & $7 / 16 / 2009-10 / 15 / 2013$ & 35 & KJEF \\
\hline BC18 & 06810000 & $\begin{array}{l}\text { Nishnabotna River above } \\
\text { Hamburg, IA }\end{array}$ & $7 / 16 / 2009-10 / 15 / 2013$ & 35 & KSTJ \\
\hline BC19 & 06810000 & $\begin{array}{l}\text { Nishnabotna River above } \\
\text { Hamburg, IA }\end{array}$ & $7 / 16 / 2009-10 / 15 / 2013$ & 35 & KSTJ \\
\hline BC20 & 06910750 & $\begin{array}{l}\text { Moreau River near Jefferson City, } \\
\text { MO }\end{array}$ & $7 / 16 / 2009-10 / 15 / 2013$ & 35 & KJEF \\
\hline BC21 & 06910750 & $\begin{array}{l}\text { Moreau River near Jefferson City, } \\
\text { MO }\end{array}$ & $7 / 16 / 2009-10 / 15 / 2013$ & 35 & KJEF \\
\hline BC22 & 06934500 & Missouri River at Hermann, MO & 9/10/2009 - 10/17/2013 & 33 & KJEF \\
\hline BC23 & 06910750 & $\begin{array}{l}\text { Moreau River near Jefferson City, } \\
\text { MO }\end{array}$ & $4 / 8 / 2010-10 / 16 / 2013$ & 31 & KJEF \\
\hline BC24 & 06810000 & $\begin{array}{l}\text { Nishnabotna River above } \\
\text { Hamburg, IA }\end{array}$ & $1 / 9 / 2007-12 / 16 / 2013$ & 81 & KSTJ \\
\hline
\end{tabular}




\begin{tabular}{|l|l|l|l|l|l|}
\hline BC25 & 06817700 & Nodaway River near Graham, MO & $4 / 5 / 2010-10 / 15 / 2013$ & 27 & KJEF \\
\hline BC26 & 06926510 & $\begin{array}{l}\text { Osage River below St. Thomas, } \\
\text { MO }\end{array}$ & $4 / 8 / 2010-10 / 16 / 2013$ & 31 & KJEF \\
\hline BC27 & 06821190 & $\begin{array}{l}\text { Platte River at Sharps Station, } \\
\text { MO }\end{array}$ & $1 / 10 / 2007-10 / 21 / 2013$ & 45 & KMCl \\
\hline
\end{tabular}

* BC represents boundary condition.

Time series plots of regression approach predicted and observed water temperatures for each of the inflow boundary sites included in the three HEC-RAS water temperature models are provided in Appendix A through C. The accuracy of the regression relationships were assessed through a visual comparison between regressions estimated, observed water temperatures, and error statistics. RMSE values calculated for each boundary condition (BC) location and each linear regression equation are listed in Table 4.

Table 4. Statistics for each boundary condition and each regression equation.

\begin{tabular}{|l|l|l|l|l|}
\hline $\begin{array}{l}\text { Water quality } \\
\text { Boundary* }\end{array}$ & $\begin{array}{l}\text { Water quality } \\
\text { gage }\end{array}$ & $\begin{array}{l}\text { No of } \\
\text { samples }\end{array}$ & $\begin{array}{l}\text { Met } \\
\text { station }\end{array}$ & RMSE \\
\hline \multicolumn{5}{|c|}{ Garrison Dam to Oahe Dam reach } \\
\hline BC1 & 06349500 & 67 & KBIS & 2.614 \\
\hline BC2 & 06349000 & 57 & KBIS & 3.491 \\
\hline BC3 & 06340500 & 56 & KBIS & 3.532 \\
\hline BC4 & 06349500 & 67 & KBIS & 2.325 \\
\hline BC5 & 06349500 & 67 & KBIS & 2.407 \\
\hline BC6 & 06342260 & 58 & KBIS & 3.272 \\
\hline BC7 & 06342450 & 42 & KBIS & 2.550 \\
\hline BC8 & 06349500 & 67 & KBIS & 2.410 \\
\hline & Gavins Point Dam to Rulo reach \\
\hline BC1 & 06813500 & 661 & KSTJ & 2.73 \\
\hline BC2 & 06485500 & 246 & KSUX & 2.763 \\
\hline BC3 & 06609500 & 145 & KOMA & 2.835 \\
\hline BC4 & 06478500 & 176 & KYKN & 2.530 \\
\hline BC5 & 06607500 & 132 & KOMA & 2.385 \\
\hline BC6 & 06467500 & 1000 & KYKN & 1.934 \\
\hline BC7 & 06478526 & 36 & KYKN & 1.744 \\
\hline BC8 & 06486000 & 871 & KYKN & 2.975 \\
\hline
\end{tabular}




\begin{tabular}{|c|c|c|c|c|}
\hline BC9 & 06486000 & 871 & KSUX & 2.795 \\
\hline BC10 & 06601200 & 201 & KSUX & 3.253 \\
\hline BC11 & 06610000 & 1157 & KOMA & 3.228 \\
\hline BC12 & 06805500 & 252 & KOMA & 2.438 \\
\hline $\mathrm{BC} 13$ & 06807000 & 1453 & KOMA & 1.839 \\
\hline BC14 & 06810000 & 135 & KOMA & 2.265 \\
\hline BC15 & 06817700 & 91 & KSTJ & 2.734 \\
\hline BC16 & 06479010 & 183 & KYKN & 2.767 \\
\hline \multicolumn{5}{|c|}{ Rulo to the mouth of the Missouri River reach } \\
\hline $\mathrm{BC} 1$ & 06810000 & 35 & KSTJ & 1.892 \\
\hline $\mathrm{BC} 2$ & 06906800 & 36 & $\mathrm{KCOU}$ & 1.735 \\
\hline $\mathrm{BC} 3$ & 06910750 & 35 & $\mathrm{KCOU}$ & 2.552 \\
\hline BC4 & 06934000 & 33 & KJEF & 2.074 \\
\hline BC5 & 06902000 & 36 & KMKC & 1.567 \\
\hline BC6 & 06892350 & 29 & KMKC & 1.193 \\
\hline $\mathrm{BC7}$ & 06906800 & 36 & $\mathrm{KCOU}$ & 1.740 \\
\hline BC8 & 06934500 & 103 & KSTL & 2.827 \\
\hline BC9 & 06807000 & 358 & KSTJ & 2.910 \\
\hline BC10 & 06818000 & 358 & $\mathrm{KMCl}$ & 2.715 \\
\hline BC11 & 06893000 & 670 & KMKC & 2.509 \\
\hline BC12 & 06894000 & 670 & KMKC & 2.468 \\
\hline BC13 & 06895000 & 670 & KMKC & 2.417 \\
\hline BC14 & 06906500 & 201 & $\mathrm{KCOU}$ & 2.461 \\
\hline BC15 & 06900900 & 2428 & KJEF & 1.785 \\
\hline BC16 & 06934500 & 103 & KSUS & 1.896 \\
\hline BC17 & 06910750 & 35 & KJEF & 1.509 \\
\hline BC18 & 06810000 & 35 & KSTJ & 1.708 \\
\hline BC19 & 06810000 & 35 & KSTJ & 1.284 \\
\hline$B C 20$ & 06910750 & 35 & KJEF & 1.284 \\
\hline BC21 & 06910750 & 35 & KJEF & 1.748 \\
\hline $\mathrm{BC} 22$ & 06934500 & 33 & KJEF & 2.540 \\
\hline $\mathrm{BC} 23$ & 06910750 & 31 & KJEF & 1.436 \\
\hline BC24 & 06810000 & 81 & KSTJ & 2.638 \\
\hline
\end{tabular}




\begin{tabular}{|l|l|l|l|l|}
\hline BC25 & 06817700 & 27 & KJEF & 2.034 \\
\hline BC26 & 06926510 & 31 & KJEF & 2.350 \\
\hline BC27 & 06821190 & 45 & KMCl & 1.983 \\
\hline
\end{tabular}

In general, stream temperatures reflect the combined influence of both meteorological and hydrological factors. Meteorological conditions, such as air temperature, has a large influence on stream temperatures; however, other factors such as solar radiation, wind speed, relative humidity, water depth, and water flow rate are also important factors. Additionally, stream temperature is greatly influenced by the source characteristics of the water, including where snowmelt occurs, surface runoff, groundwater inflow, or cultural heat inputs. Each source characteristic has a different temperature signature, with surface runoff ranging close to the ambient air temperature and snowmelt ranging just above freezing. As a result, the relative influence of meteorological and hydrologic factors on stream temperature can vary greatly with watershed and/or season.

After reviewing all comparisons of regression approach predicted water temperature and observed data presented in Appendix A-C, the water temperature computed by the regression approach was satisfactory in general. For a few stream gaging stations, the fitted regression equations were, however, questionable if not useless (i.e., their $\mathrm{R}^{2}$ values were below o.5). Stefan and Preud'homme (1993) developed an air-water regression model based on daily and weekly water temperature data from 11 streams in the central United States. Their study indicated that the dependence of regression coefficients on stream characteristics and weather parameters other than air temperature is evident in some streams. Not being able to capture the temporal variations in observed water temperature for some locations within the Missouri River basin may be a result of the weak airwater temperature correlations or lack of observed data. In these locations, air-water temperature correlations may not be appropriate for computing water temperature boundary conditions. Therefore, the authors recommend using the current HEC-RAS water temperature model for assessing the relative changes of water temperatures associated with management alternatives along the Missouri River instead of using them to assess absolute deterministic values. 


\subsection{Model development and calibration}

All HEC-RAS water temperature models were constructed based on the calibrated HEC-RAS flow models the USACE Omaha and Kansas City Districts provided. The following sections discuss each modeled river reach separately.

\subsubsection{Fort Peck Dam to Garrison Dam River Reach}

\subsubsection{HEC-RAS flow model}

The Fort Peck Dam to Garrison Dam reach of the Missouri River begins at RM 1769.04, located just downstream of Fort Peck Dam in MT, and extend to RM 1391.08, located upstream of Garrison Dam on Lake Sakakawea, Pick City, ND. The reach is approximately 365 miles long. This is the most upstream portion of the Missouri River being modeled with HECRAS. USACE Omaha District developed and calibrated the unsteady HECRAS flow model for the Fort Peck Dam to Garrison Dam reach (USACE 2015). The model extent and tributaries entering the Missouri River within this reach are shown in Figure 15.

Figure 15. HEC-RAS model extent for the Fort Peck Dam to Garrison Dam reach (USACE 2015).

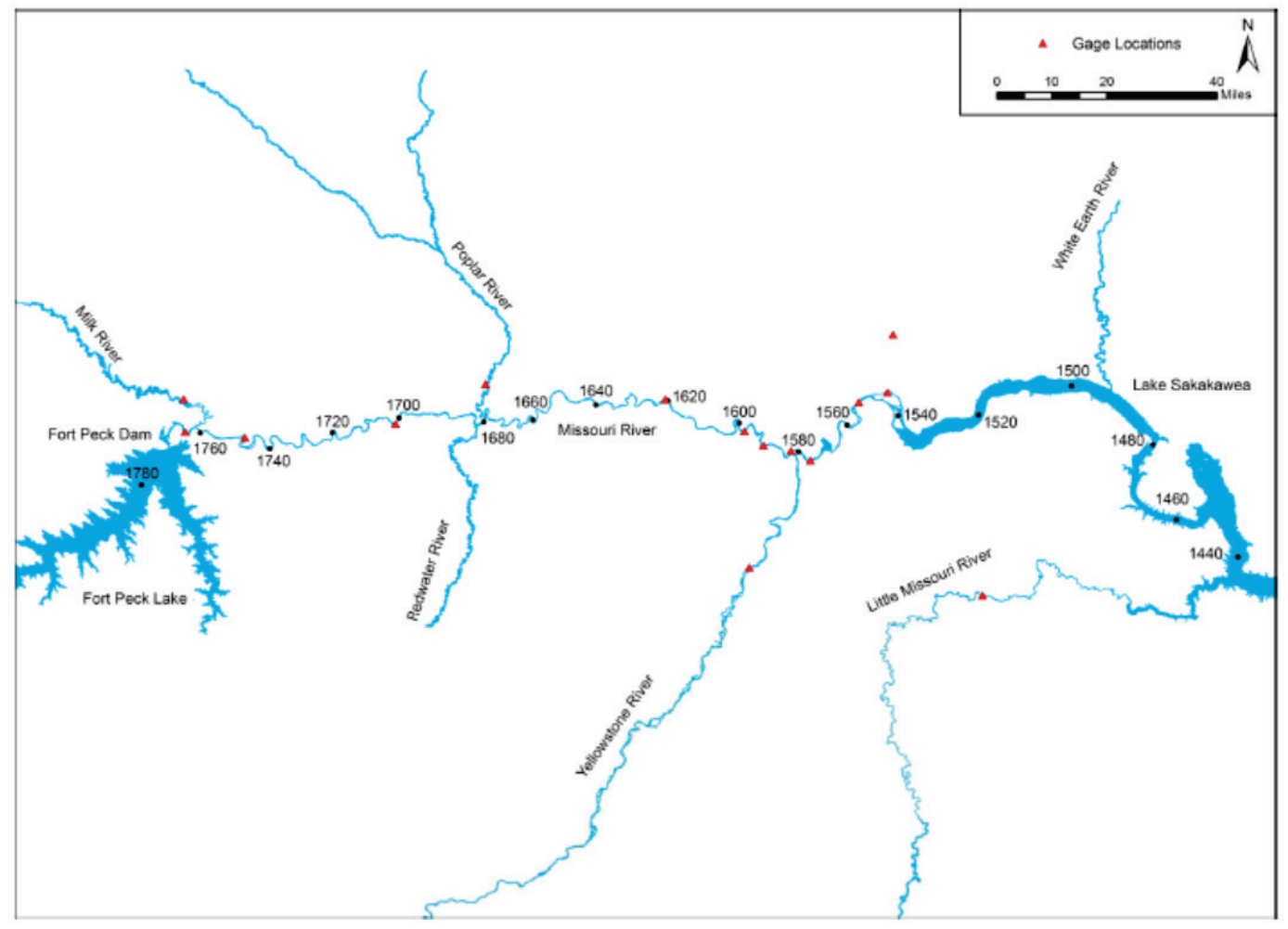


In addition to the Missouri River, three tributary reaches were included within the HEC-RAS model to route flow from the gage station to the Missouri River. The three tributary routing reaches are:

- Milk River, which extends approximately 24 miles from the confluence within the Missouri River to Nashua, MT

- Poplar River, near Poplar, Montana, extends 14 miles upstream from the confluence within the Missouri River

- Yellowstone River, which extends approximately 62 miles from the confluence within the Missouri River to Sydney, MT.

\subsubsection{Water temperature model inputs}

Once a HEC-RAS flow model is calibrated, meteorological data and inflow temperature boundary conditions are primary model inputs for the water temperature model. They are time and space dependent and discussed below.

\section{Meteorological data}

Two meteorological stations (KGGW and KISN), shown in Figure 1, were used in the Fort Peck Dam to Garrison Dam reach of the HEC-RAS water temperature model. In HEC-RAS, the dataset from the nearest station was automatically assigned to water quality computational cells within the river reach.

\section{Boundary conditions}

The required boundary conditions for the HEC-RAS water temperature model are the water temperatures at the upstream boundary (Fort Peck Dam release temperatures), and water temperatures from all lateral and distributed inflow discharging into this reach. Table 5 below provides a list of flow boundary locations in the HEC-RAS model and observed water temperature records at these locations. If a water quality monitoring station was not available for the inflow boundary, observed data collected from adjacent water quality stations were used. Thus, the same water quality station is listed in Table 5 for different inflow boundaries.

Since the HEC-RAS water temperature model results for this reach were not needed for conducting current ManPlan and EIS, the regression relationships described previously were not developed and applied to compute inflow water temperature boundary conditions for this river 
reach. Observed water temperatures for each boundary listed in Table 5 were directly used in the water temperature model.

Table 5. Flow and temperature boundaries included in the HEC-RAS model for the Fort Peck Dam to Garrison Dam reach

\begin{tabular}{|c|c|c|c|c|c|c|}
\hline Inflow boundary & $\begin{array}{c}\text { Flow boundary } \\
\text { type }\end{array}$ & $\begin{array}{l}\text { Water } \\
\text { quality } \\
\text { boundary }\end{array}$ & $\begin{array}{l}\text { Water quality } \\
\text { station ID }\end{array}$ & $\begin{array}{l}\text { Water quality } \\
\text { station location }\end{array}$ & $\begin{array}{l}\text { Temperature } \\
\text { Records }\end{array}$ & $\begin{array}{l}\text { Number of } \\
\text { samples }\end{array}$ \\
\hline $\begin{array}{l}\text { Milk River XS } \\
23.54\end{array}$ & Tributary & $\mathrm{BC} 1$ & $06174500^{3}$ & $\begin{array}{l}\text { Milk River, Nashua, } \\
\text { MT }\end{array}$ & $\begin{array}{l}5 / 7 / 2010- \\
10 / 20 / 2013\end{array}$ & 643 \\
\hline $\begin{array}{l}\text { Poplar River } \\
\text { XS14.18 }\end{array}$ & Tributary & $\mathrm{BC} 2$ & $06181000^{3}$ & $\begin{array}{l}\text { Poplar River, } \\
\text { Poplar, MT }\end{array}$ & $\begin{array}{l}1 / 26 / 2000- \\
7 / 30 / 2013\end{array}$ & 128 \\
\hline $\begin{array}{l}\text { Yellowstone River } \\
\text { XS } 103500\end{array}$ & Tributary & $\mathrm{BC} 3$ & $06329500^{3}$ & $\begin{array}{l}\text { Yellowstone River, } \\
\text { Sidney, MT }\end{array}$ & $\begin{array}{l}1 / 11 / 2000- \\
10 / 30 / 2013\end{array}$ & 615 \\
\hline $\begin{array}{l}\text { Little Missouri XS } \\
81.59\end{array}$ & Tributary & $\mathrm{BC} 4$ & GARNFMORR ${ }^{1}$ & $\begin{array}{l}\text { Garrison Reservoir } \\
\text { inflow }\end{array}$ & $\begin{array}{l}4 / 6 / 2010- \\
10 / 29 / 2013\end{array}$ & 24 \\
\hline $\begin{array}{l}\text { Missouri River XS } \\
1769\end{array}$ & $\begin{array}{l}\text { Upstream } \\
\text { boundary }\end{array}$ & $\mathrm{BC} 5$ & FTPlake $^{1}$ & Fort Peck Lake & $\begin{array}{l}6 / 14 / 2010- \\
10 / 1 / 2012\end{array}$ & 420 \\
\hline $\begin{array}{l}\text { Missouri River XS } \\
1768\end{array}$ & Lateral inflow & $\mathrm{BC} 5$ & FTPlake & Fort Peck Lake & $\begin{array}{l}\text { 6/14/2010 - } \\
10 / 1 / 2012\end{array}$ & 420 \\
\hline $\begin{array}{l}\text { Missouri River XS } \\
1762\end{array}$ & Lateral inflow & $\mathrm{BC} 5$ & FTPlake & Fort Peck Lake & $\begin{array}{l}6 / 14 / 2010- \\
10 / 1 / 2012\end{array}$ & 420 \\
\hline $\begin{array}{l}\text { Missouri River XS } \\
1761\end{array}$ & Lateral inflow & $\mathrm{BC} 6$ & FTPPP1 ${ }^{1}$ & $\begin{array}{l}\text { Fort Peck Dam } \\
\text { Powerplant, MT }\end{array}$ & $\begin{array}{l}1 / 1 / 2010- \\
1 / 1 / 2014\end{array}$ & 35065 \\
\hline $\begin{array}{l}\text { Missouri River XS } \\
1760\end{array}$ & Lateral inflow & $\mathrm{BC} 7$ & USGS $(1761.4)^{2}$ & $\begin{array}{l}\text { Missouri River, Fort } \\
\text { Peck Dam, MT }\end{array}$ & $\begin{array}{l}5 / 7 / 2010- \\
8 / 4 / 2013\end{array}$ & 265 \\
\hline $\begin{array}{l}\text { Missouri River XS } \\
1744\end{array}$ & Lateral inflow & $\mathrm{BC} 8$ & USGS $(1744.8)^{2}$ & $\begin{array}{l}\text { Missouri River, } \\
\text { Frazer, MT }\end{array}$ & $\begin{array}{l}5 / 7 / 2010- \\
9 / 1 / 2013\end{array}$ & 474 \\
\hline $\begin{array}{l}\text { Missouri River XS } \\
1725\end{array}$ & Lateral inflow & $\mathrm{BC9}$ & USGS (1741) 2 & $\begin{array}{l}\text { Missouri River, } \\
\text { Grant Champs, MT }\end{array}$ & $\begin{array}{l}5 / 7 / 2010- \\
9 / 1 / 2013\end{array}$ & 643 \\
\hline $\begin{array}{l}\text { Missouri River XS } \\
1717\end{array}$ & Lateral inflow & BC10 & USGS $(1696.9)^{2}$ & $\begin{array}{l}\text { Missouri River, } \\
\text { Wolf Point, MT }\end{array}$ & \begin{tabular}{|l}
$5 / 7 / 2010-$ \\
$10 / 20 / 2013$
\end{tabular} & 656 \\
\hline $\begin{array}{l}\text { Missouri River XS } \\
1708\end{array}$ & Lateral inflow & $\mathrm{BC} 10$ & USGS (1696.9) & $\begin{array}{l}\text { Missouri River, } \\
\text { Wolf Point, MT }\end{array}$ & $\begin{array}{l}5 / 7 / 2010- \\
10 / 20 / 2013\end{array}$ & 656 \\
\hline $\begin{array}{l}\text { Missouri River XS } \\
1701\end{array}$ & Lateral inflow & BC10 & USGS (1696.9) & $\begin{array}{l}\text { Missouri River, } \\
\text { Wolf Point, MT }\end{array}$ & $\begin{array}{l}5 / 7 / 2010- \\
10 / 20 / 2013\end{array}$ & 656 \\
\hline $\begin{array}{l}\text { Missouri River XS } \\
1689\end{array}$ & Lateral inflow & $\mathrm{BC} 10$ & USGS (1696.9) & $\begin{array}{l}\text { Missouri River, } \\
\text { Wolf Point, MT }\end{array}$ & $\begin{array}{l}5 / 7 / 2010- \\
10 / 20 / 2013\end{array}$ & 656 \\
\hline $\begin{array}{l}\text { Missouri River XS } \\
1681\end{array}$ & Lateral inflow & $\mathrm{BC} 10$ & USGS (1696.9) & $\begin{array}{l}\text { Missouri River, } \\
\text { Wolf Point, MT }\end{array}$ & $\begin{array}{l}5 / 7 / 2010- \\
10 / 20 / 2013\end{array}$ & 656 \\
\hline $\begin{array}{l}\text { Missouri River XS } \\
1678\end{array}$ & Lateral inflow & BC10 & USGS (1696.9) & $\begin{array}{l}\text { Missouri River, } \\
\text { Wolf Point, MT }\end{array}$ & \begin{tabular}{|l}
$5 / 7 / 2010-$ \\
$10 / 20 / 2013$
\end{tabular} & 656 \\
\hline
\end{tabular}




\begin{tabular}{|l|l|l|l|l|l|l|}
\hline $\begin{array}{l}\text { Missouri River XS } \\
1645\end{array}$ & Lateral inflow & BC11 & USGS (1615.1) & $\begin{array}{l}\text { Missouri River, } \\
\text { Culbertson, MT }\end{array}$ & $\begin{array}{l}5 / 7 / 2010- \\
10 / 1 / 2013\end{array}$ & 502 \\
\hline $\begin{array}{l}\text { Missouri River XS } \\
1630\end{array}$ & Lateral inflow & BC11 & USGS (1615.1) & $\begin{array}{l}\text { Missouri River, } \\
\text { Culbertson, MT }\end{array}$ & $\begin{array}{l}5 / 7 / 2010- \\
10 / 1 / 2013\end{array}$ & 502 \\
\hline $\begin{array}{l}\text { Missouri River XS } \\
1627\end{array}$ & Lateral inflow & BC11 & USGS (1615.1) & $\begin{array}{l}\text { Missouri River, } \\
\text { Culbertson, MT }\end{array}$ & $\begin{array}{l}5 / 7 / 2010- \\
10 / 1 / 2013\end{array}$ & 502 \\
\hline $\begin{array}{l}\text { Missouri River XS } \\
1623\end{array}$ & Lateral inflow & BC11 & USGS (1615.1) & $\begin{array}{l}\text { Missouri River, } \\
\text { Culbertson, MT }\end{array}$ & $\begin{array}{l}5 / 7 / 2010- \\
10 / 1 / 2013\end{array}$ & 502 \\
\hline $\begin{array}{l}\text { Missouri River XS } \\
1545\end{array}$ & Lateral inflow & BC12 & USGS (1573.6) 2 & $\begin{array}{l}\text { Missouri River } \\
\text { below Yellowstone } \\
\text { River, MT }\end{array}$ & $\begin{array}{l}5 / 7 / 2010- \\
10 / 1 / 2013\end{array}$ & 330 \\
\hline
\end{tabular}

1. USACE Omaha District provided water temperature data for these locations

2. The USGS provided water temperature data for these locations

3. USGS gage.

\subsubsection{Water temperature model set up and calibration}

When the water temperature model for the Fort Peck Dam to Garrison Dam reach is opened, water quality computational cells are initially established between cross sections along this river reach. However, in situations where hydraulic cross sections have been placed very close together (such as around bridges or other hydraulic structures), default water quality cells may be very small. A single small water quality cell will force the model to choose a correspondingly small time step. For this river reach, the minimum water quality cell length was set as $1000 \mathrm{ft}$., which directs the model to combine water quality cells to ensure that the all cells are at least as long as this user specified minimum.

After specifying above meteorological data and boundary conditions, the HEC-RAS water temperature model for the Fort Peck Dam to Garrison Dam reach was set up and run using an hourly time step from January 1, 2011-September 30, 2012 based on available water temperature boundary data. All gaps in observed water temperature data used for boundary conditions were linearly interpolated in the HEC-RAS water temperature model. The model results generated using this approach are questionable if gaps in observed water temperature are big, for example, a month or longer time interval. An hourly time step was also used in the other HECRAS water temperature models described in this chapter.

The HEC-RAS water temperature model for the Fort Peck Dam to Garrison Dam reach was not used in conducting current ManPlan and EIS. 
The water temperature model for this river reach was preliminarily calibrated with available observed data. During the model calibration, solar radiation and coefficients in the wind speed function were adjusted. Time series plots of HEC-RAS predicted and observed water temperatures at five USGS stations along the Fort Peck Dam to Garrison Dam reach are presented in Figures 16-20.

Figure 16. HEC-RAS predicted versus observed water temperatures of the Missouri River at Frazer, MT.

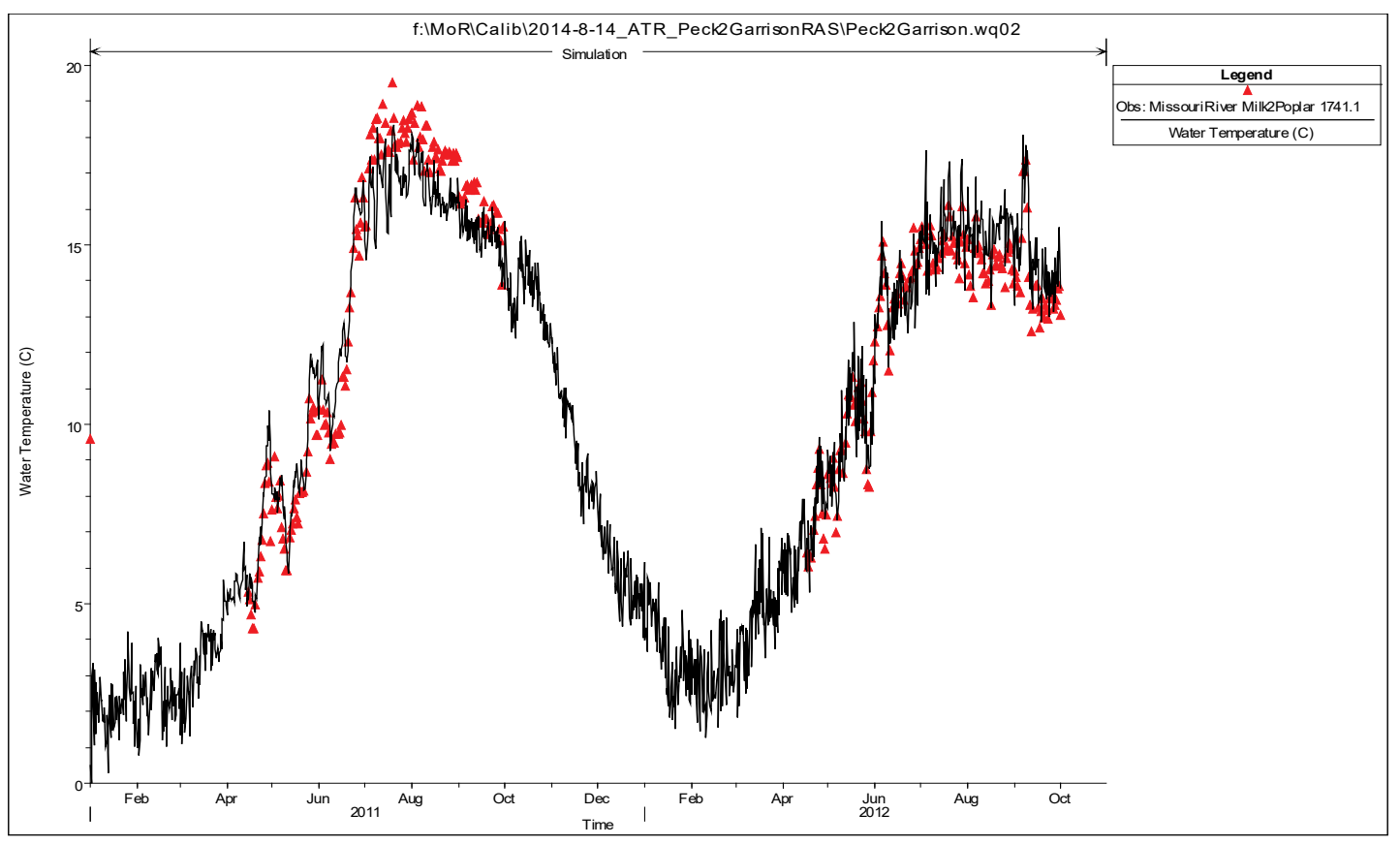


Figure 17. HEC-RAS predicted versus observed water temperatures of the Missouri River at Wolf, MT.

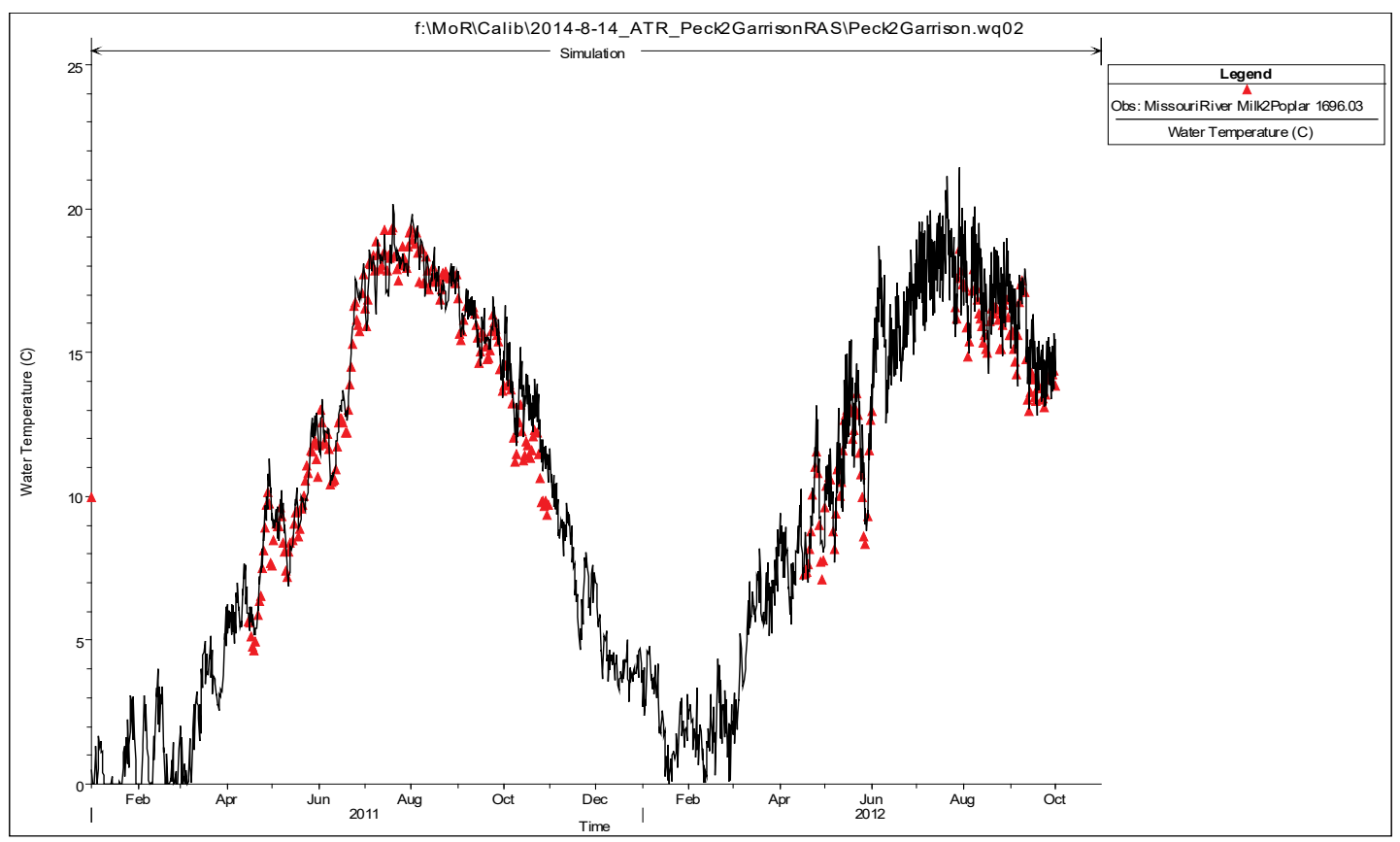

Figure 18. HEC-RAS predicted versus observed water temperatures of the Missouri River at Culbertson, MT.

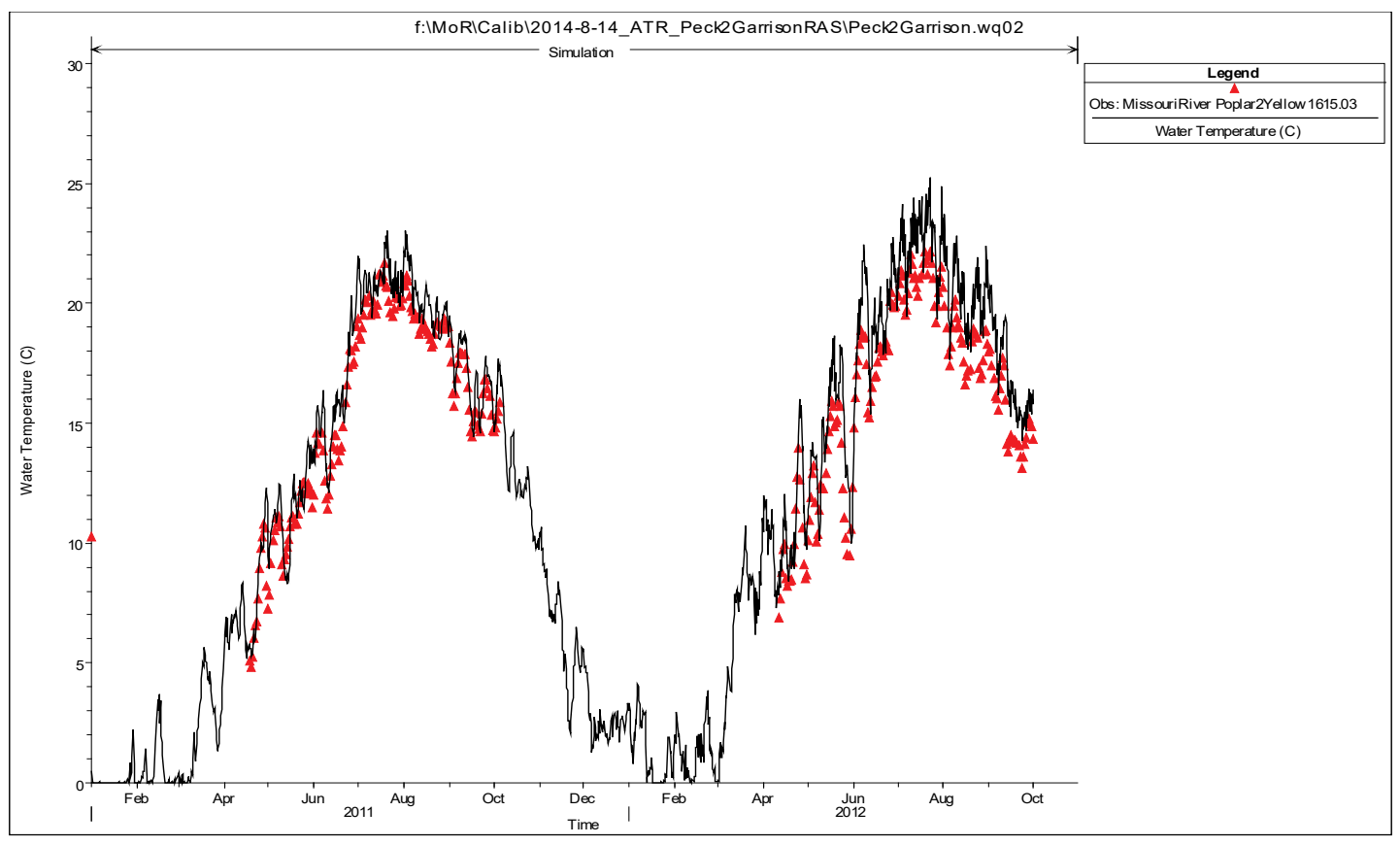


Figure 19. HEC-RAS predicted versus observed water temperatures of the Missouri River at Nohly, MT.

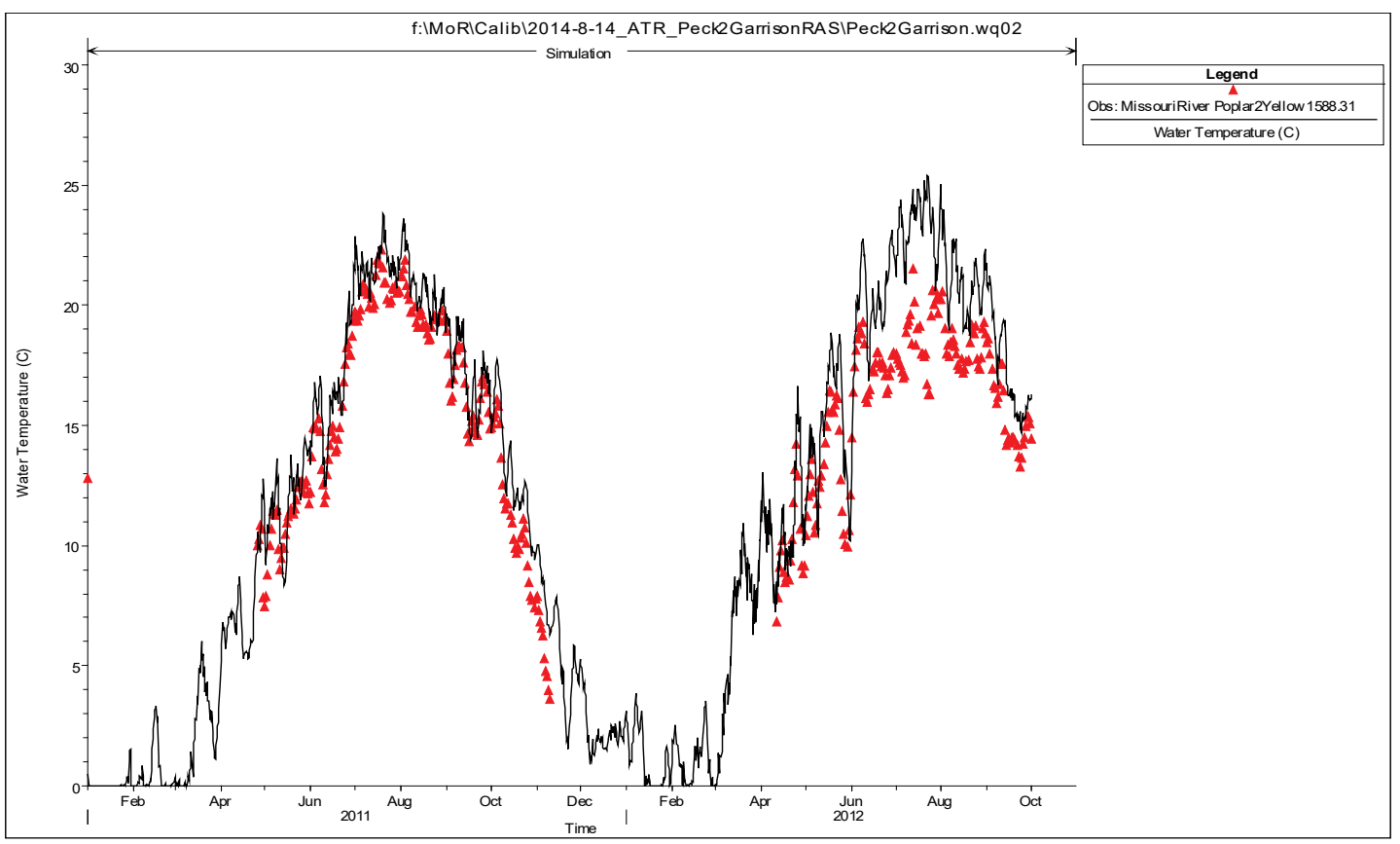

Figure 20. HEC-RAS predicted versus observed water temperatures of the Missouri River at Williston, MT.

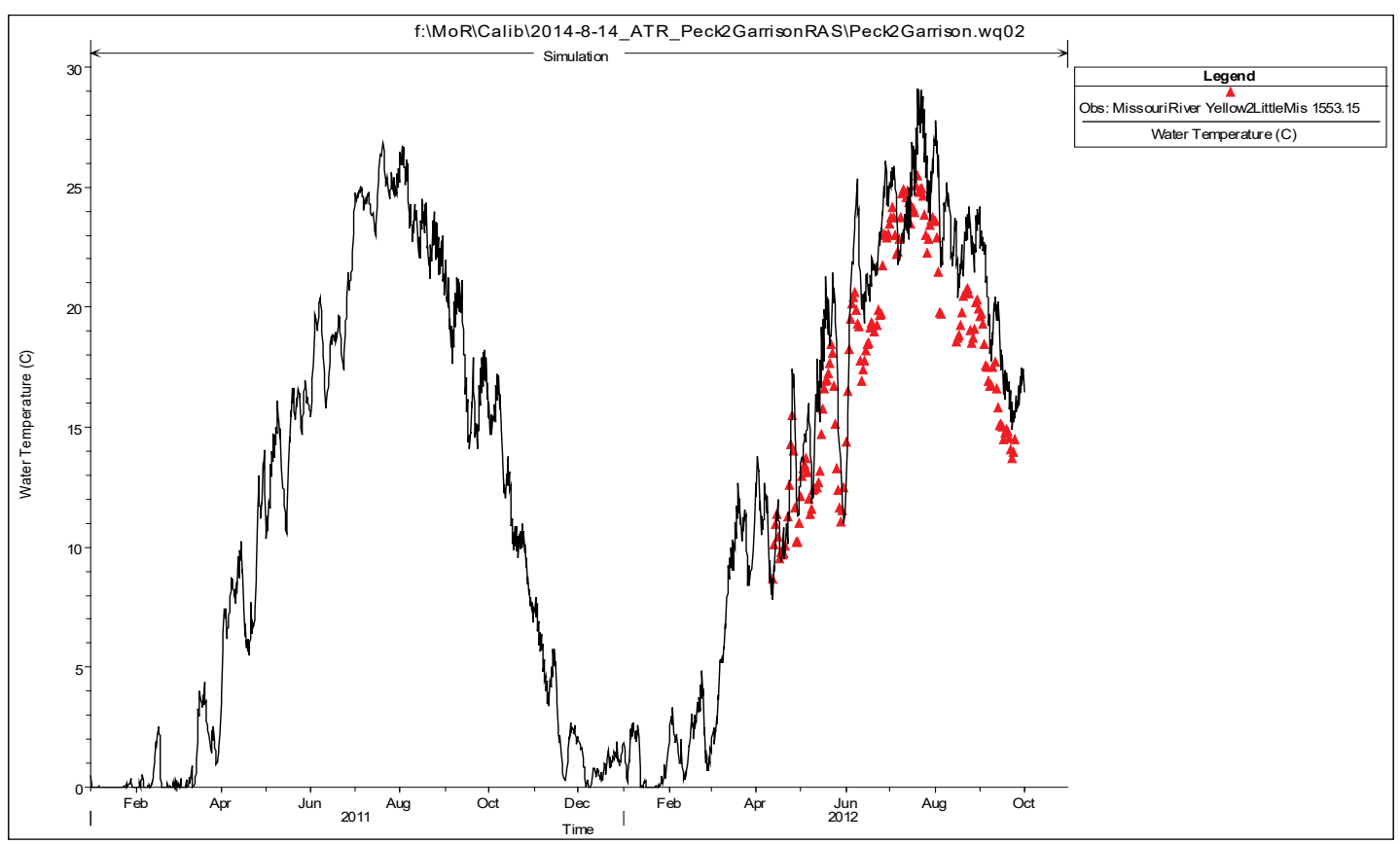

These figures show a scatter plot of instantaneous temperature predictions against time-stamped temperature observations. Comparisons of model predictions and observed data at USGS stations along this river reach demonstrate the degree that the HEC-RAS model captures the 
instantaneous water temperature observations at these locations. The main differences between modeled and observed values occur during summer seasons when the model predictions tend to be higher than the observed temperatures.

\subsubsection{Garrison Dam to Oahe Dam River Reach}

\subsubsection{HEC-RAS flow model}

The Garrison Dam to Oahe Dam reach of the Missouri River begins from RM 1388.30, located just downstream of Garrison Dam, ND, to RM 1073.04, located upstream of Oahe Dam, Pierre, SD. The reach is approximately 318 miles long. The Garrison Dam to Oahe Dam reach of the Missouri River is the second reach being modeled with HEC-RAS. USACE Omaha District developed and calibrated the unsteady HEC-RAS flow model (USACE 2015). Figure 21 shows the extent of the model as well as tributaries entering the Missouri River within this reach. USGS stations shown in this figure are only flow gages. 
Figure 21. HEC-RAS model extent for the Garrison Dam to Oahe Dam reach (USACE 2015).

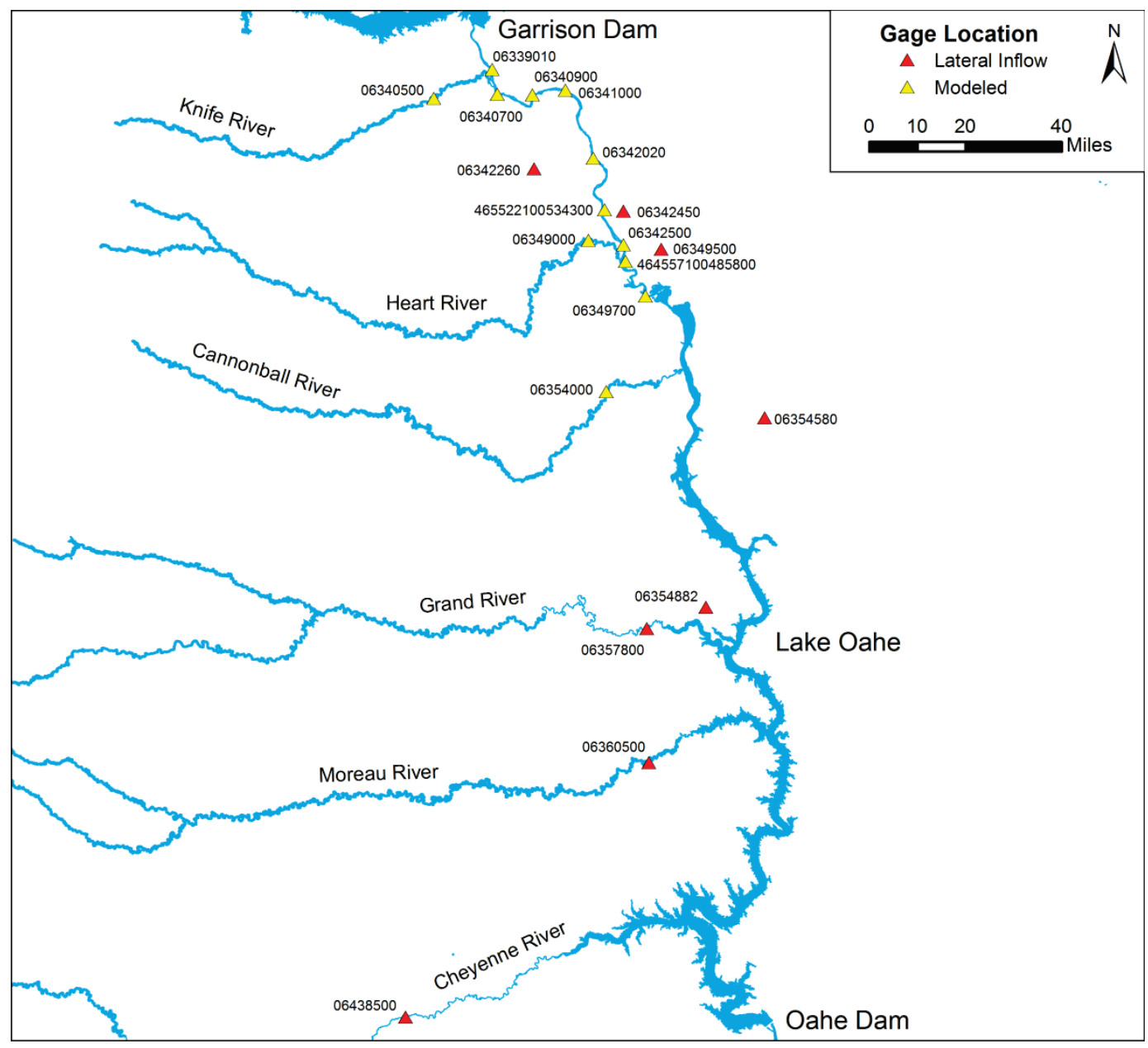

In addition to modeling the Missouri River, three tributary reaches were included within the HEC-RAS model to route flow from the gage station to the Missouri River. The three tributary routing reaches are:

- The Knife River, which extends approximately 26 miles from the confluence within the Missouri River to Hazen, ND

- The Heart River, which extends approximately 11 miles from the confluence within the Missouri River to near Mandan, ND

- The Cannonball River, which extends approximately 30 miles from the confluence within the Missouri River to Breien, ND.

\subsubsection{Water temperature model Inputs}

Meteorological data and inflow temperature boundary conditions for the Garrison Dam to Oahe Dam reach HEC-RAS water temperature model are discussed below. 


\section{Meteorological data}

One meteorological station (KBIS) at Bismarck Muni, ND, shown in Figure 1, was used in the Garrison Dam to Oahe Dam reach HEC-RAS water temperature model.

\section{Boundary conditions}

Figure 22 presents approximate locations of inflow boundaries included in the Garrison Dam to Oahe Dam reach HEC-RAS model. Water temperatures associated with each inflow boundary for the simulation period (1995-2012) were computed using regression relationships as explained previously. The water temperatures from Garrison Dam release and inflow temperatures for all tributaries along the reach were specified in the model through a HEC-DSS file. Table 6 lists 25 water temperature boundary conditions, which correspond to their inflow boundaries included in the HEC-RAS model for the Garrison Dam to Oahe Dam reach.

Figure 22. Schematic representation of inflow boundary locations included in the HEC-RAS model for the Garrison Dam to Oahe Dam reach.

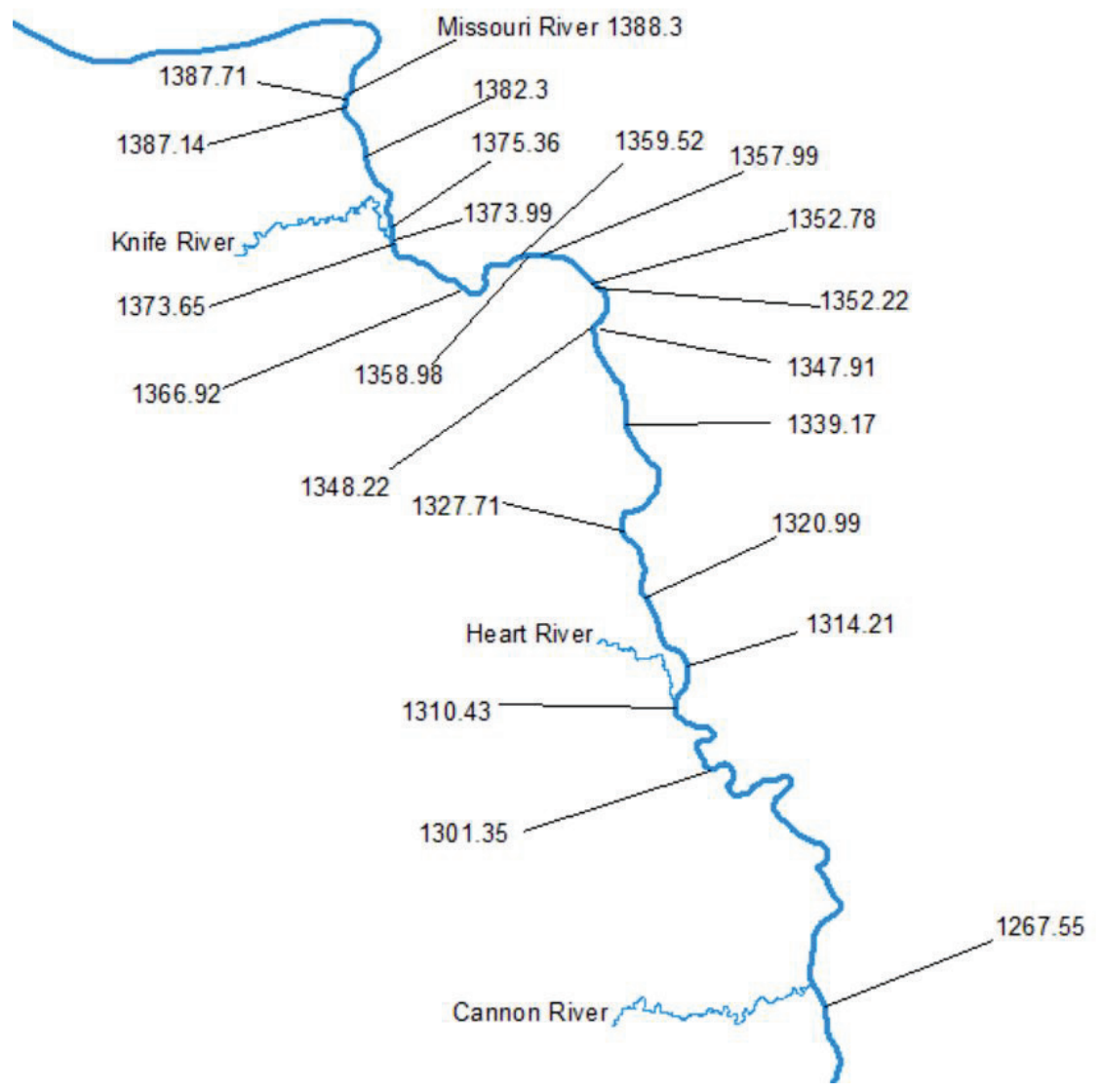


Table 6. Inflow and temperature boundaries included in the HEC-RAS model for the Garrison Dam to Oahe Dam reach.

\begin{tabular}{|c|c|c|c|}
\hline NO & Flow boundary & Flow boundary type & $\begin{array}{l}\text { Water quality } \\
\text { boundary }\end{array}$ \\
\hline 1 & Cannon River RS 29.67 & Tributary & $\mathrm{BC} 1$ \\
\hline 2 & Heart River RS 10.95 & Tributary & $\mathrm{BC} 2$ \\
\hline 3 & Knife River RS 25.86 & Tributary & BC3 \\
\hline 4 & Missouri River RS 1388.30 & $\begin{array}{l}\text { Upstream boundary } \\
\text { from dam release }\end{array}$ & $\mathrm{BC} 4$ \\
\hline 5 & Missouri River RS 1387.71 & Uniform lateral inflow & BC3 \\
\hline 6 & Missouri River RS 1387.71 & Uniform lateral inflow & BC3 \\
\hline 7 & Missouri River RS 1382.30 & Lateral inflow & BC3 \\
\hline 8 & Missouri River RS 1375.36 & Lateral inflow & BC3 \\
\hline 9 & Missouri River RS 1373.99 & Uniform lateral inflow & BC3 \\
\hline 10 & Missouri River RS 1373.99 & Uniform lateral inflow & BC3 \\
\hline 11 & Missouri River RS 1366.92 & Lateral inflow & BC5 \\
\hline 12 & Missouri River RS 1359.52 & Lateral inflow & BC5 \\
\hline 13 & Missouri River RS 1358.98 & Lateral inflow & BC5 \\
\hline 14 & Missouri River RS 1357.99 & Lateral inflow & BC5 \\
\hline 15 & Missouri River RS 1352.22 & Lateral inflow & BC5 \\
\hline 16 & Missouri River RS 1352.22 & Lateral inflow & BC5 \\
\hline 17 & Missouri River RS 1348.22 & Lateral inflow & BC5 \\
\hline 18 & Missouri River RS 1348.22 & Lateral inflow & BC5 \\
\hline 19 & Missouri River RS 1339.17 & Lateral inflow & BC5 \\
\hline 20 & Missouri River RS 1327.71 & Lateral inflow & BC6 \\
\hline 21 & Missouri River RS 1320.99 & Lateral inflow & $\mathrm{BC} 7$ \\
\hline 22 & Missouri River RS 1314.21 & Uniform lateral inflow & $\mathrm{BC} 7$ \\
\hline 23 & Missouri River RS 1310.43 & Uniform lateral inflow & BC8 \\
\hline 24 & Missouri River RS 1301.35 & Lateral inflow & BC8 \\
\hline 25 & Missouri River RS 1267.55 & Uniform lateral inflow & BC8 \\
\hline
\end{tabular}

\subsubsection{Water temperature model set up and calibration}

After specifying above meteorological data and boundary conditions, the HEC-RAS temperature model for the Garrison Dam to Oahe Dam reach was set up and run using an hourly time step from January 1, 1995- 
December 31, 2012. Figure 23 shows the schematic and data plan of the HEC-RAS temperature model for this reach. The minimum water quality cell length in HEC-RAS was set as $1000 \mathrm{ft}$.

Figure 23. Schematic and data plan of the HEC-RAS temperature model for the Garrison Dam to Oahe Dam reach.

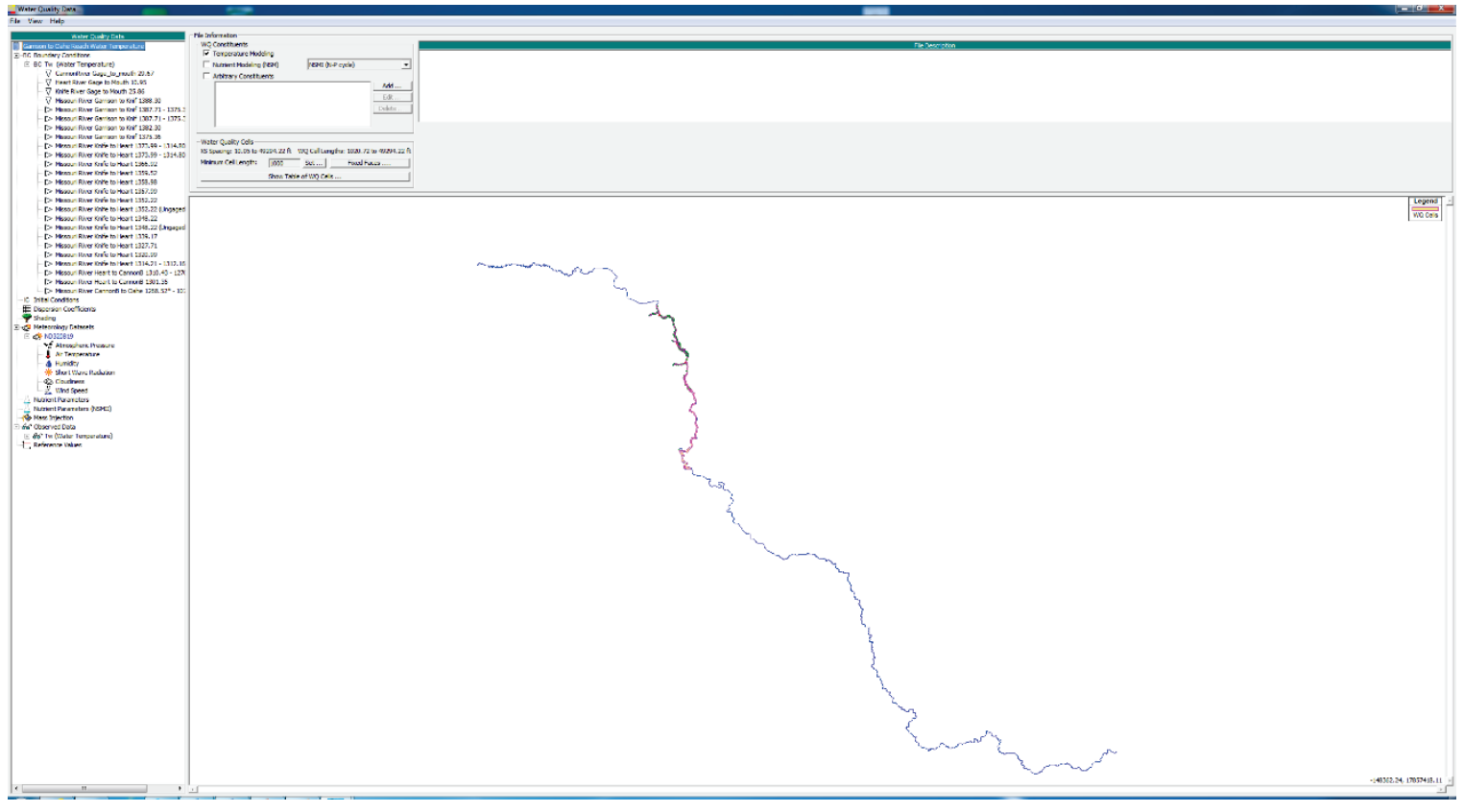

The HEC-RAS water temperature model for the Garrison Dam to Oahe Dam reach was preliminarily calibrated at two USGS stations (0634100o and 06342500 ) on the main stem Missouri River. Their locations can be found in Figure 21. Time series plots of HEC-RAS predicted and observed data at these two stations are presented in Figure 24 and Figure 25. 
Figure 24. HEC-RAS predicted versus observed water temperatures of the Missouri River at Washburn, ND (USGS 06341000).

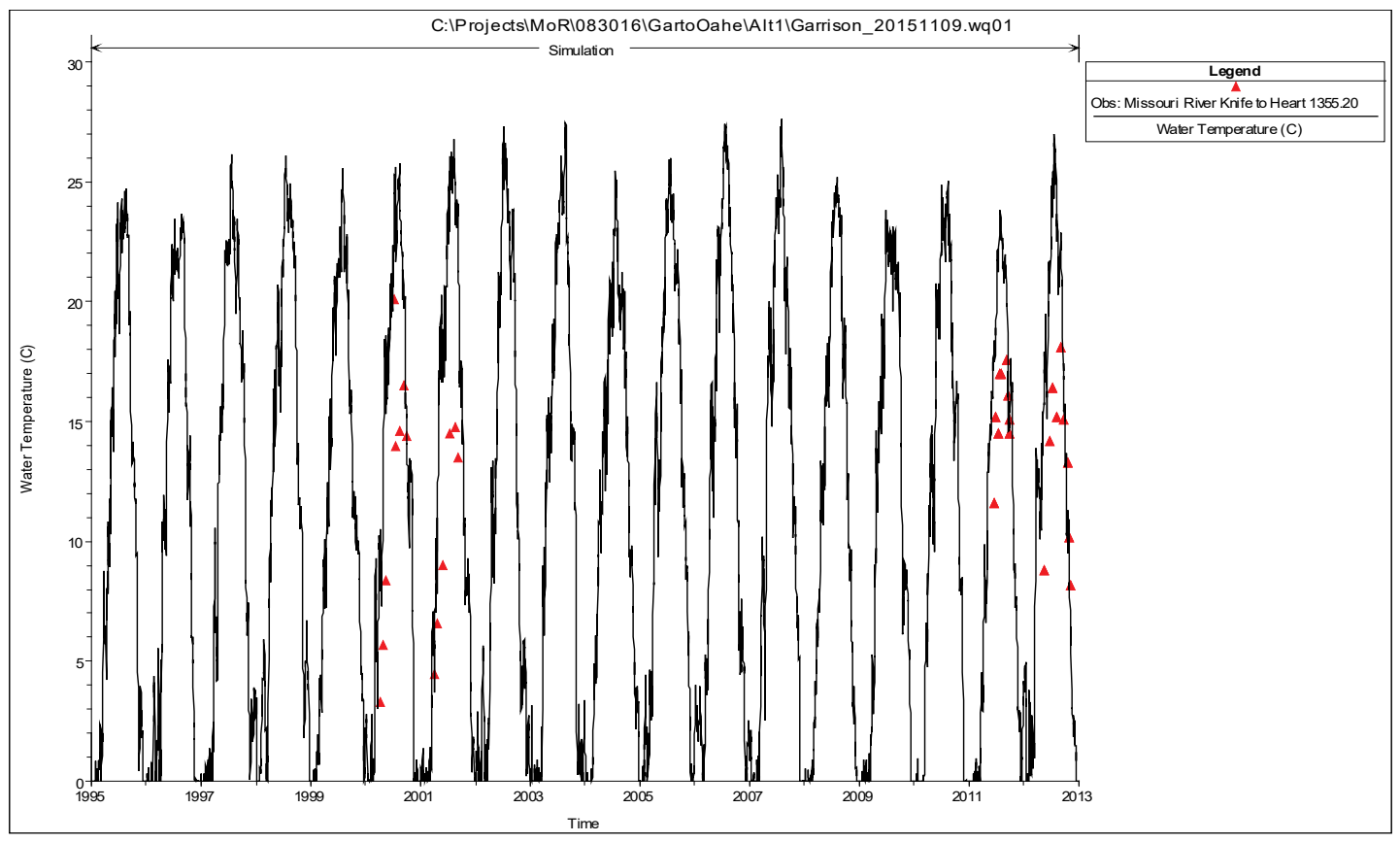

Figure 25. HEC-RAS predicted versus observed water temperatures of the Missouri River at Bismarck, ND (USGS 06342500).

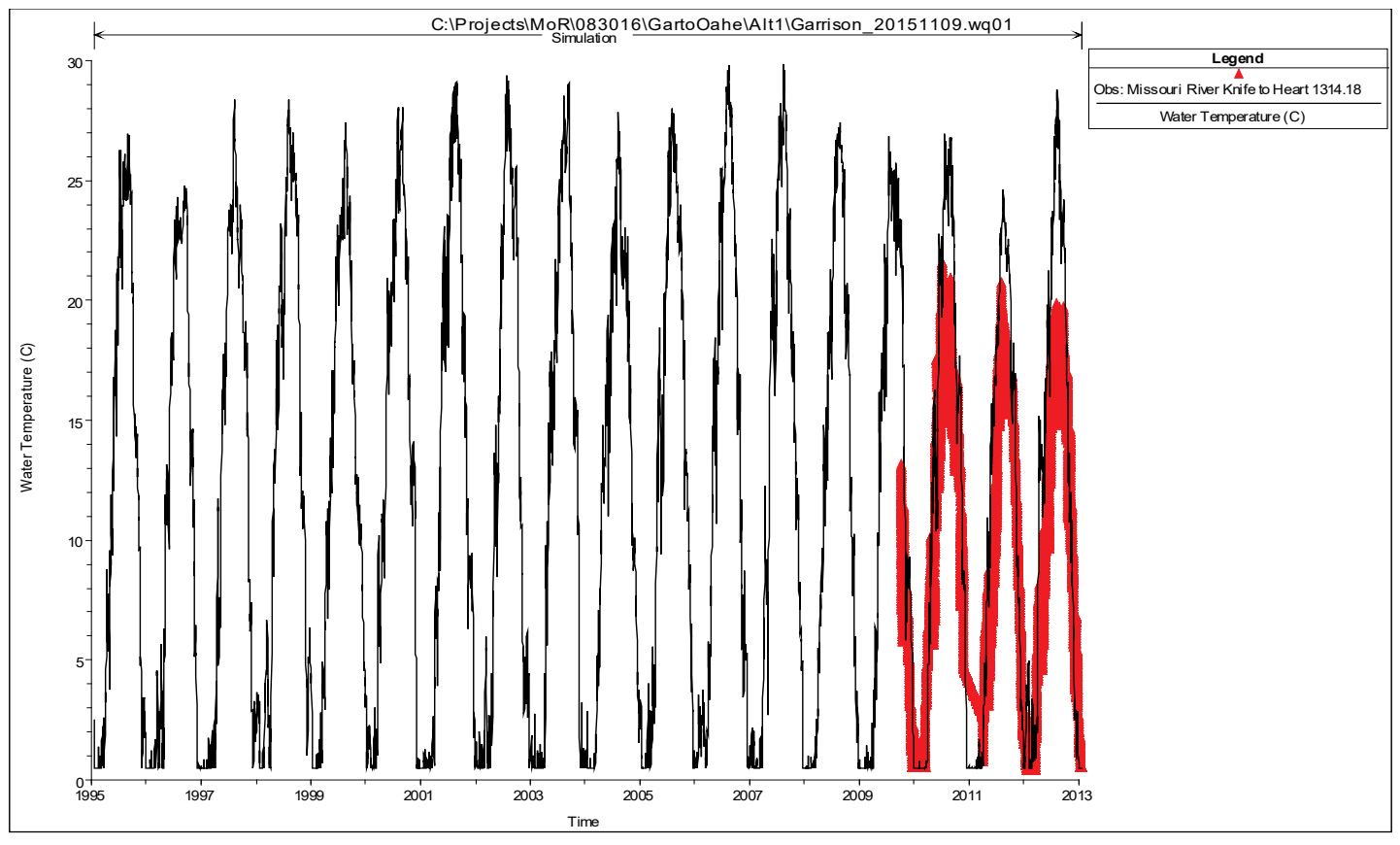

The HEC-RAS model for the Fort Peck Dam to Garrison Dam reach captured the seasonal variations of observed water temperatures well; 
however, the model over predicted summer temperatures at both locations along this reach.

\subsubsection{Fort Randall Dam to Gavins Point Dam River Reach}

\subsubsection{HEC-RAS flow model}

The Fort Randall Dam to Gavins Point Dam reach of the Missouri River begins from RM 879.04, located just downstream of Fort Randall Dam, SD, to RM 812.74, located upstream of Gavins Point Dam on Lewis and Clark Lake, Yankton, SD. The reach is approximately 70 miles long. The Fort Randall Dam to Gavins Point Dam reach is the third reach of the Missouri River being modeled with HEC-RAS. USACE Omaha District developed and calibrated the unsteady HEC-RAS flow model (USACE 2015). The model extent and tributaries entering the Missouri River within this reach are shown in Figure 26. USGS stations shown in this figure are only flow gages.

Figure 26. HEC-RAS model extent for the Fort Randall Dam to Gavins Point Dam reach (USACE 2015).

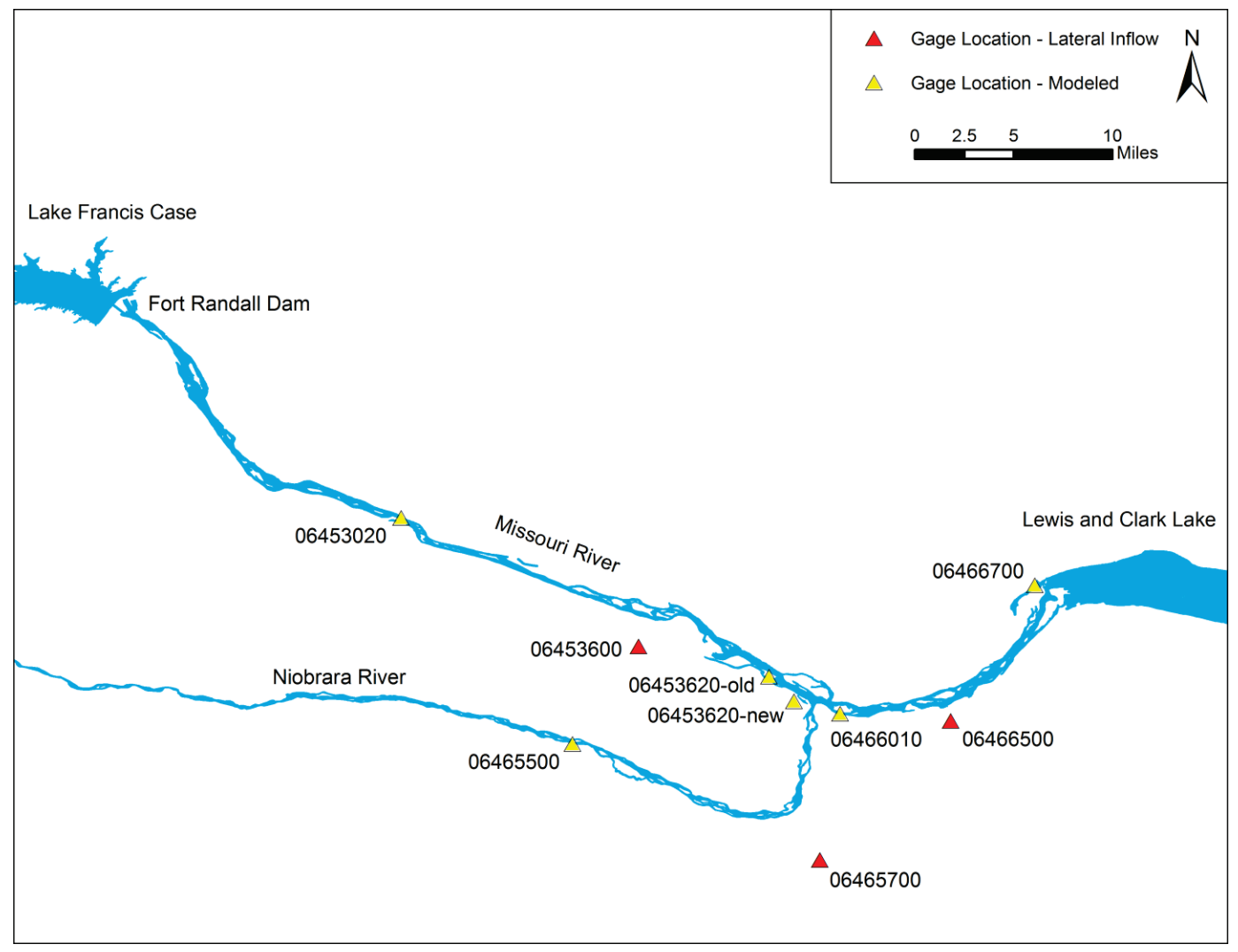


In addition to modeling the Missouri River, there is one tributary modeled in HEC-RAS. The Niobrara River model extends approximately 15 miles upstream from the confluence within the Missouri River to near Verdel, NE. The Niobrara River watershed is approximately 12,000 square miles.

\subsubsection{Water temperature model Inputs}

Meteorological data and inflow temperature boundary conditions for the Fort Randall Dam to Gavins Point Dam reach HEC-RAS model are discussed below.

\section{Meteorological data}

Two meteorological stations (NYKN and KONL), shown in Figure 1, were used in the Fort Randall Dam to Gavins Point Dam reach HEC-RAS water temperature model. In HEC-RAS, the data from each meteorological station was automatically assigned to the closest water quality computational cells within the river reach.

\section{Boundary conditions}

Table 7 below provides a list of inflow boundary locations and their water temperature inputs included in the Fort Randall Dam to Gavins Point Dam reach HEC-RAS model. USGS 06465500 was used twice because it was the only water quality station on the Niobrara River.

The HEC-RAS water temperature model results for this reach were not needed for the ManPlan analysis. In addition, the air-water temperature regression approach was not applied to all inflow boundaries for computing the water temperatures. Observed water temperatures for each boundary listed in Table 5 were directly used in the HEC-RAS water temperature model. All gaps in observed water temperature data used for boundary conditions were linearly interpolated in the HEC-RAS model. 
Table 7. Flow and temperature boundaries included in the HEC-RAS model for the Fort Randall Dam to Gavins Point Dam reach

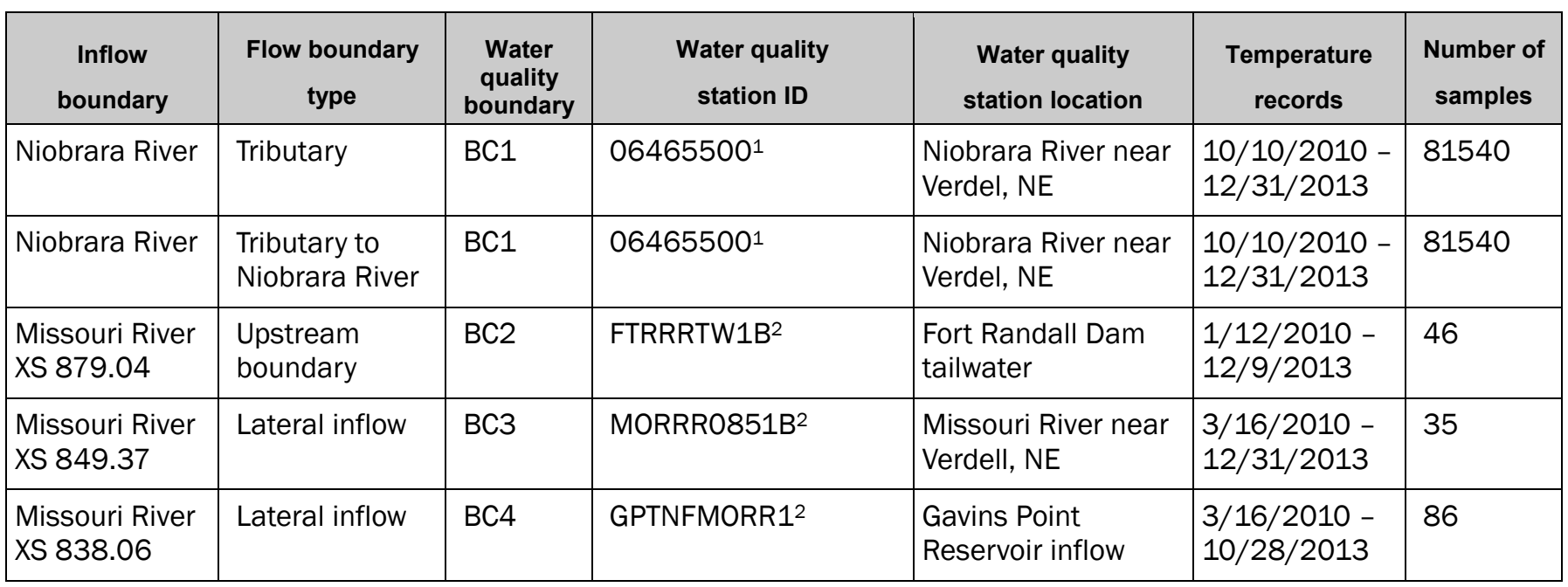

1. USGS gage

2. USACE Omaha District provided water temperature data for these locations

\subsubsection{Water temperature model set up and calibration}

The HEC-RAS water temperature model for the Fort Randall Dam to Gavins Point Dam reach was not used in conducting current ManPlan and EIS The model was set up and run using an hourly time step for two years, from January 1, 2011-December 31, 2012. The minimum water quality cell length in HEC-RAS was set as $1000 \mathrm{ft}$. Only one location (USGS 06466700) on this river reach had observed water temperature data. A time series plot of HEC-RAS predicted and observed water temperatures at this location is presented in Figure 27. 
Figure 27. HEC-RAS predicted versus observed water temperatures of the Missouri River at Springfield, SD (USGS 06466700).

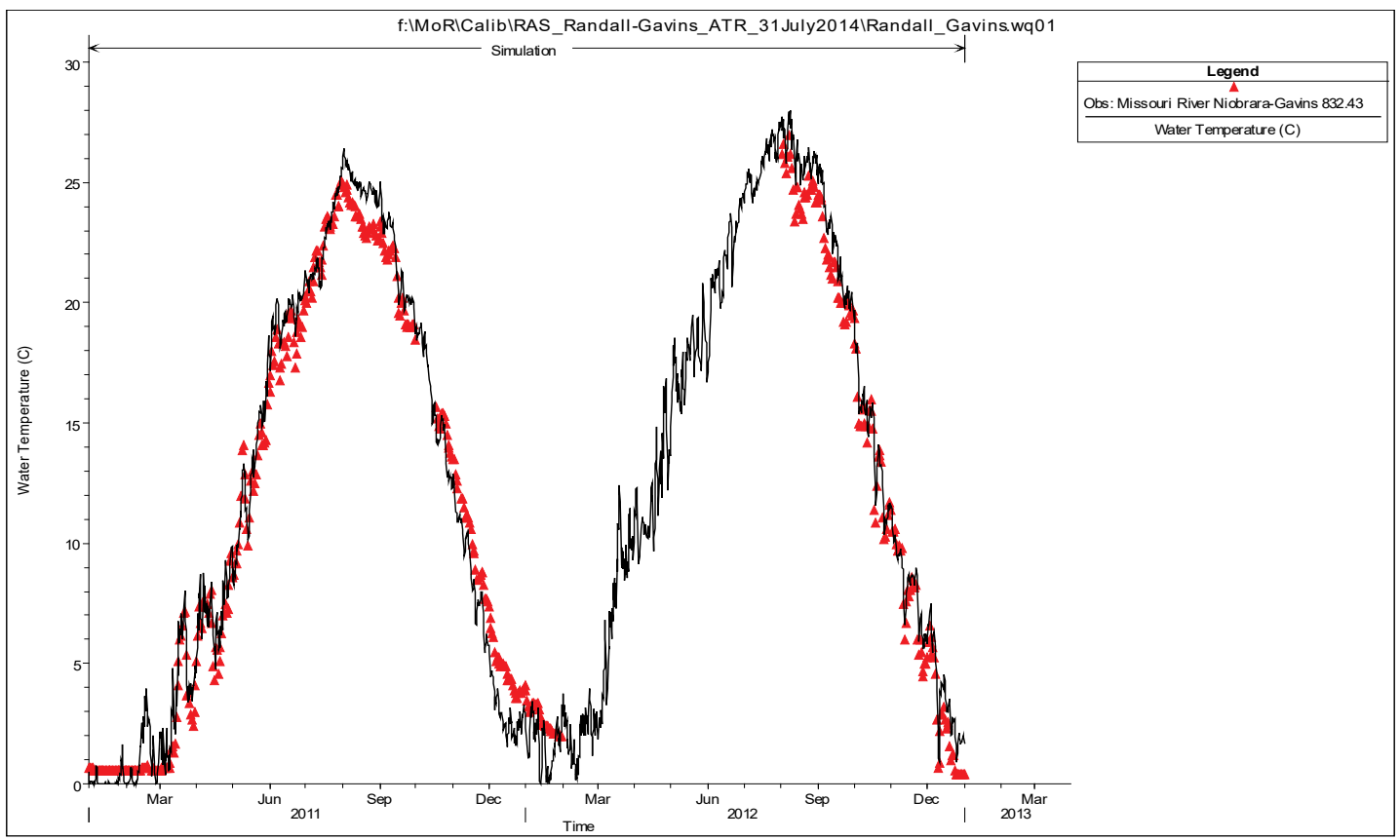

Comparisons of model predictions and observed data at this location show that the Fort Randall Dam to Gavins Point Dam HEC-RAS model was able to capture water temperature observation patterns. The minor differences between modeled and observed values occur during summer seasons when the model predictions tend to be slightly higher than the observed temperature.

\subsubsection{Gavins Point Dam to Rulo River Reach}

\subsubsection{HEC-RAS flow model}

The Gavins Point Dam to Rulo, NE, reach of the Missouri River begins with the regulated outflow from Gavins Point Dam in SD at RM 811.1. The reach extends approximately 250 miles downstream to Rulo, NE at RM 498.o. The USACE Omaha District developed and calibrated the unsteady HEC-RAS flow model for this reach (USACE 2015). The model extent and tributaries entering the Missouri River for the Gavins Point Dam to Rulo reach are shown in Figure 28. USGS stations shown in this figure are only flow gages. 
Figure 28. HEC-RAS model extent for the Gavins Point Dam to Rulo reach (USACE 2015).

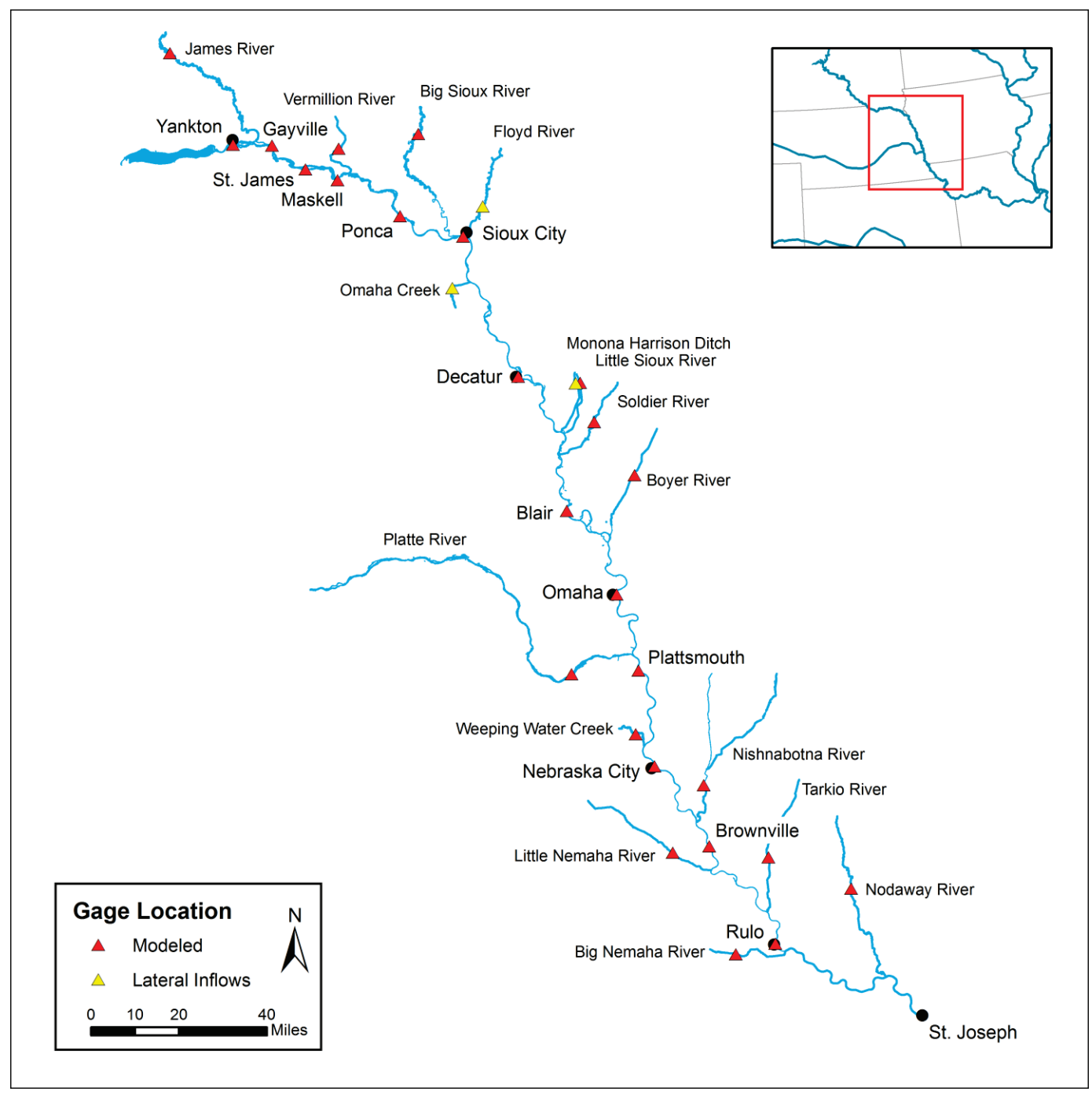

Refer to the model schematic shown in Figure 28 for the locations of significant tributaries, many tributaries enter the Gavins Point Dam to Rulo reach. Major tributaries were simulated as separate routing reaches within the HEC-RAS model. Minor tributaries that have USGS gage data were included as lateral inflow to the model.

\subsubsection{Water temperature model inputs}

Meteorological data and inflow temperature boundary conditions for the Gavins Point Dam to Rulo reach HEC-RAS model are discussed below.

\section{Meteorological Data}

Four meteorological stations (NYKN, KSUX, KOMA, and KSTJ), shown in Figure 1, were used in the Gavins Point Dam to Rulo reach HEC-RAS 
temperature model. In HEC-RAS, the meteorological data from each station was automatically assigned to the closest water quality computational cells within the river reach.

\section{Boundary conditions}

Figure 29 presents approximate locations of inflow boundaries included in the Gavins Point Dam to Rulo reach HEC-RAS model. Water temperatures associated with each inflow boundary for the simulation period (1995-2012) were computed using regression relationships as explained previously in this chapter. The water temperatures from Gavins Point Dam release and inflow temperatures for all tributaries along the reach were specified in the model through a HEC-DSS file. Table 8. Inflow and temperature boundaries included in the HEC-RAS model for the Gavins Point Dam to Rulo reach. lists all water temperature boundaries corresponding to inflow boundaries along this river reach. If a water quality monitoring station was not available for the inflow boundary, observed data collected from adjacent water quality stations were used in the HEC-RAS water temperature model. 
Figure 29. Schematic representation of inflow boundary locations included in the HEC-RAS model for the Gavins Point Dam to the Rulo reach.

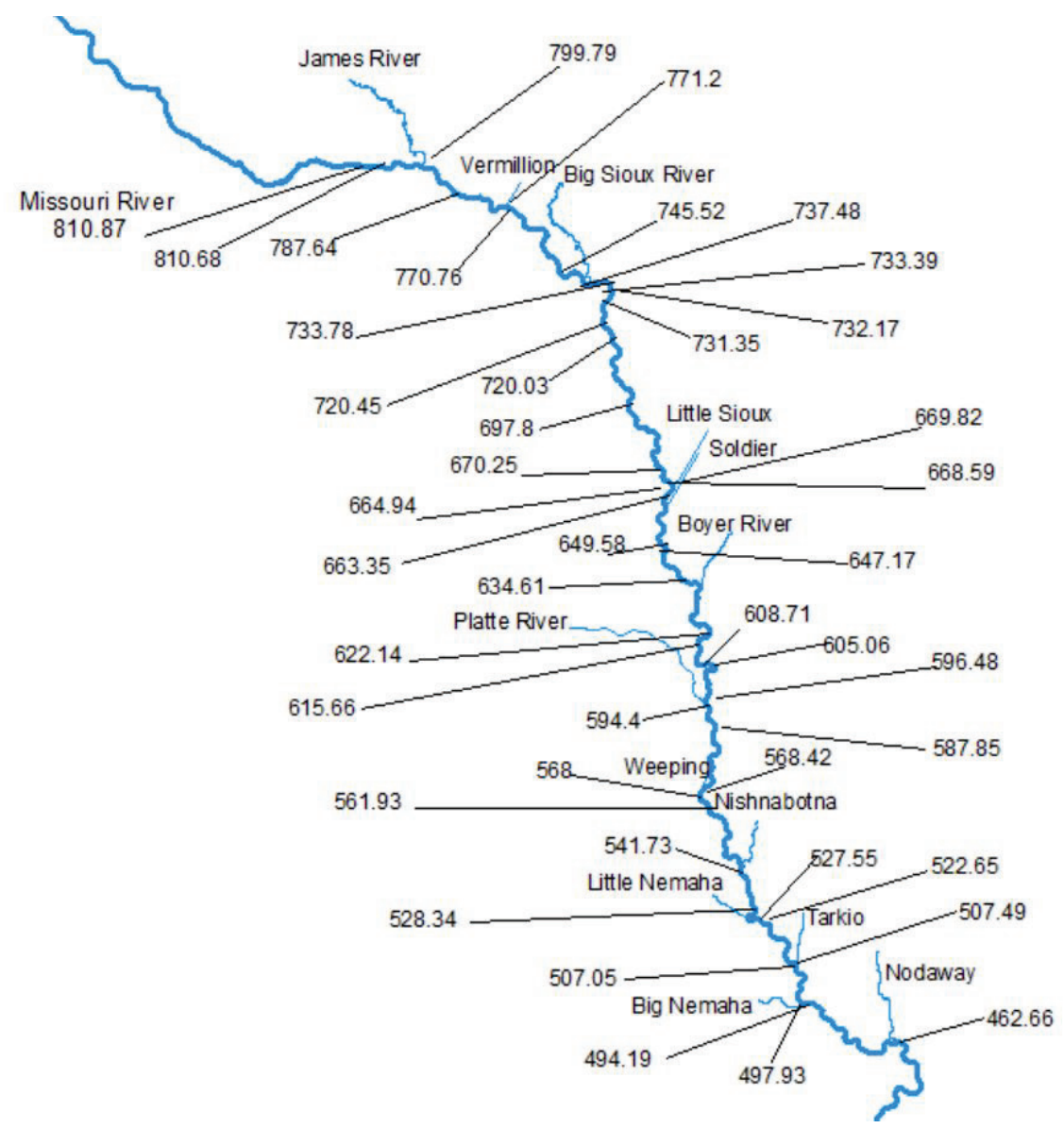

Table 8. Inflow and temperature boundaries included in the HEC-RAS model for the Gavins Point Dam to Rulo reach.

\begin{tabular}{|l|l|l|l|}
\hline No & Inflow boundary & Flow boundary type & $\begin{array}{l}\text { Water quality } \\
\text { boundary }\end{array}$ \\
\hline 1 & Big Nemaha River RS 13.66 & Tributary & BC1 \\
\hline 2 & Big Sioux River RS 50.93 & Tributary & BC2 \\
\hline 3 & Boyer River RS 15.75 & Tributary & BC3 \\
\hline 4 & James River RS 55.606 & Tributary & BC4 \\
\hline 5 & Little Nemaha River RS 10.52 & Tributary & BC1 \\
\hline 6 & Little Sioux River RS 13.35 & Tributary & BC5 \\
\hline 7 & Missouri River RS 810.87 & $\begin{array}{l}\text { Upstream boundary from dam } \\
\text { release }\end{array}$ & BC6 \\
\hline 8 & Missouri River RS 810.68 & Uniform lateral inflow & BC6 \\
\hline 9 & Missouri River RS 810.68 & Uniform lateral inflow (withdraw) & \\
\hline 10 & Missouri River RS 799.79 & Uniform lateral inflow (withdraw) & \\
\hline
\end{tabular}




\begin{tabular}{|c|c|c|c|}
\hline 11 & Missouri River RS 799.79 & Uniform lateral inflow & $\mathrm{BC} 7$ \\
\hline 12 & Missouri River RS 787.64 & Lateral inflow & $\mathrm{BC} 7$ \\
\hline 13 & Missouri River RS 771.20 & Uniform lateral inflow & BC8 \\
\hline 14 & Missouri River RS 771.20 & Uniform lateral inflow (withdraw) & \\
\hline 15 & Missouri River RS 770.76 & Lateral inflow & BC8 \\
\hline 16 & Missouri River RS 745.52 & Lateral inflow & BC9 \\
\hline 17 & Missouri River RS 737.48 & Lateral inflow & BC9 \\
\hline 18 & Missouri River RS 733.39 & Lateral inflow & BC9 \\
\hline 19 & Missouri River RS 733.39 & Uniform lateral inflow & BC9 \\
\hline 20 & Missouri River RS 732.17 & Lateral inflow & BC9 \\
\hline 21 & Missouri River RS 732.17 & Uniform lateral inflow & BC9 \\
\hline 22 & Missouri River RS 731.35 & Lateral inflow & BC9 \\
\hline 23 & Missouri River RS 720.45 & Lateral inflow & BC9 \\
\hline 24 & Missouri River RS 720.03 & Lateral inflow & BC9 \\
\hline 25 & Missouri River RS 697.80 & Lateral inflow & BC10 \\
\hline 26 & Missouri River RS 670.25 & Lateral inflow & BC10 \\
\hline 27 & Missouri River RS 670.25 & Lateral inflow & BC10 \\
\hline 28 & Missouri River RS 668.59 & Uniform lateral inflow & BC10 \\
\hline 29 & Missouri River RS 664.94 & Lateral inflow & $\mathrm{BC} 3$ \\
\hline 30 & Missouri River RS 663.35 & Uniform lateral inflow (withdraw) & \\
\hline 31 & Missouri River RS 663.35 & Uniform lateral inflow & BC3 \\
\hline 32 & Missouri River RS 649.58 & Lateral inflow & $\mathrm{BC} 3$ \\
\hline 33 & Missouri River RS 647.17 & Lateral inflow & $\mathrm{BC} 3$ \\
\hline 34 & Missouri River RS 634.61 & Uniform lateral inflow & BC11 \\
\hline 35 & Missouri River RS 622.14 & Lateral inflow & BC11 \\
\hline 36 & Missouri River RS 615.66 & Uniform lateral inflow & BC11 \\
\hline 37 & Missouri River RS 605.06 & Lateral inflow & $\mathrm{BC} 12$ \\
\hline 38 & Missouri River RS 596.48 & Lateral inflow & $\mathrm{BC} 12$ \\
\hline 39 & Missouri River RS 594.4 & Uniform lateral inflow & BC12 \\
\hline 40 & Missouri River RS 587.85 & Lateral inflow & $\mathrm{BC} 12$ \\
\hline 41 & Missouri River RS 568 & Uniform lateral inflow & $\mathrm{BC} 13$ \\
\hline 42 & Missouri River RS 561.93 & Uniform lateral inflow & BC13 \\
\hline 43 & Missouri River RS 541.73 & Uniform lateral inflow & BC14 \\
\hline 44 & Missouri River RS 528.34 & Lateral inflow & BC1 \\
\hline
\end{tabular}




\begin{tabular}{|l|l|l|l|}
\hline 45 & Missouri River RS 527.55 & Uniform lateral inflow & BC1 \\
\hline 46 & Missouri River RS 522.65 & Uniform lateral inflow & BC1 \\
\hline 47 & Missouri River RS 507.49 & Uniform lateral inflow & BC1 \\
\hline 48 & Missouri River RS 507.05 & Uniform lateral inflow & BC1 \\
\hline 49 & Nishnabotna River RS 61570 & Tributary & BC14 \\
\hline 50 & Nodaway River RS 28.91 & Tributary & BC15 \\
\hline 51 & Platte River RS 16.74 & Tributary & BC13 \\
\hline 52 & Soldier River RS 13.09 & Tributary & BC5 \\
\hline 53 & Tarkio River RS 13.56 & Tributary & BC1 \\
\hline 54 & Vermillion River RS 10.17 & Tributary & BC16 \\
\hline 55 & Weeping River RS 6.19 & Tributary & BC13 \\
\hline
\end{tabular}

\subsubsection{Water temperature model set up and calibration}

The HEC-RAS temperature model for the Gavins Point Dam to Rulo reach was set up and run using an hourly time step from January 1, 1995December 31, 2012. Figure 30 shows the schematic and data plan of the HEC-RAS temperature model for this reach. The minimum water quality cell length in HEC-RAS was set as $1000 \mathrm{ft}$.

Figure 30. Schematic and data plan of the HEC-RAS temperature model for the Gavins Point Dam to Rulo reach.

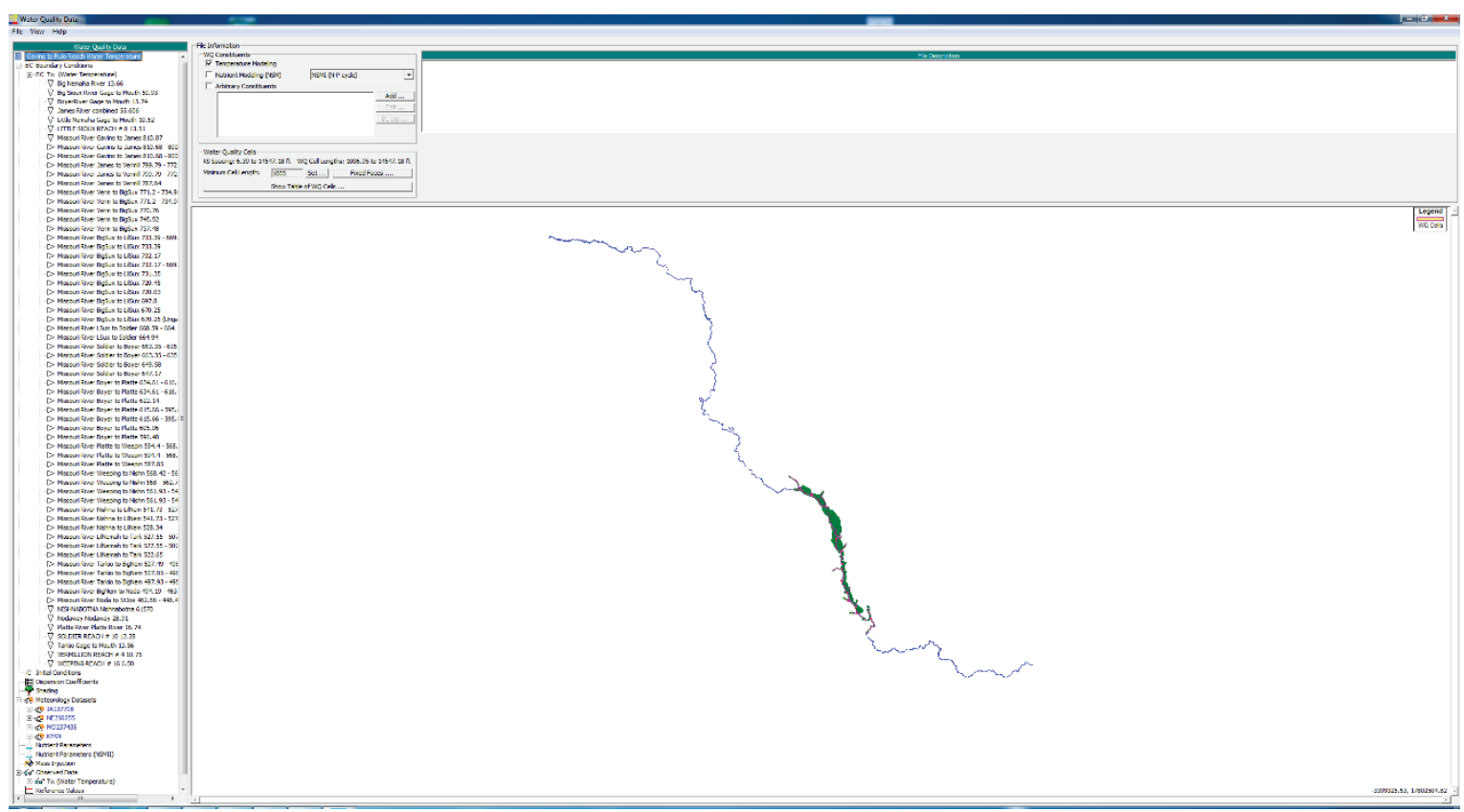


The HEC-RAS water temperature model calibration for the Gavins Point Dam to Rulo reach primarily focused on six USGS stations with observed data along this reach. These six USGS stations are 06478526, 06486000, 06601200, 06610000, 06807000, and 06813500. Their locations on the main stem Missouri River are shown in Figure 31. Time series plots of HEC-RAS predicted and observed data are presented in Figures 32-37.

Figure 31. HEC-RAS water temperature calibration locations from the Gavins Point Dam to the mouth of the Missouri River.

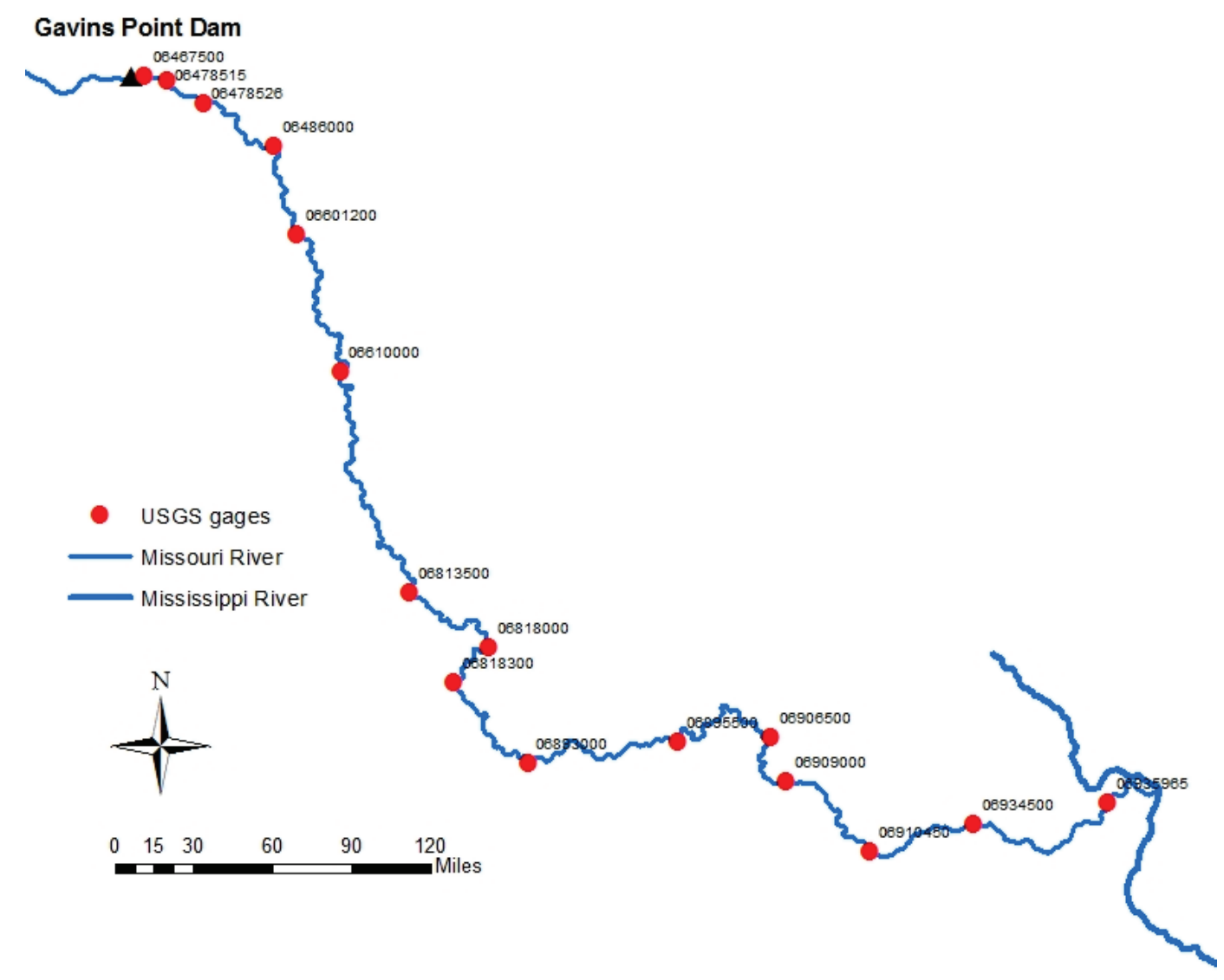


Figure 32. HEC-RAS predicted versus observed water temperatures of the Missouri River near Maskell, NE (USGS 06478526).

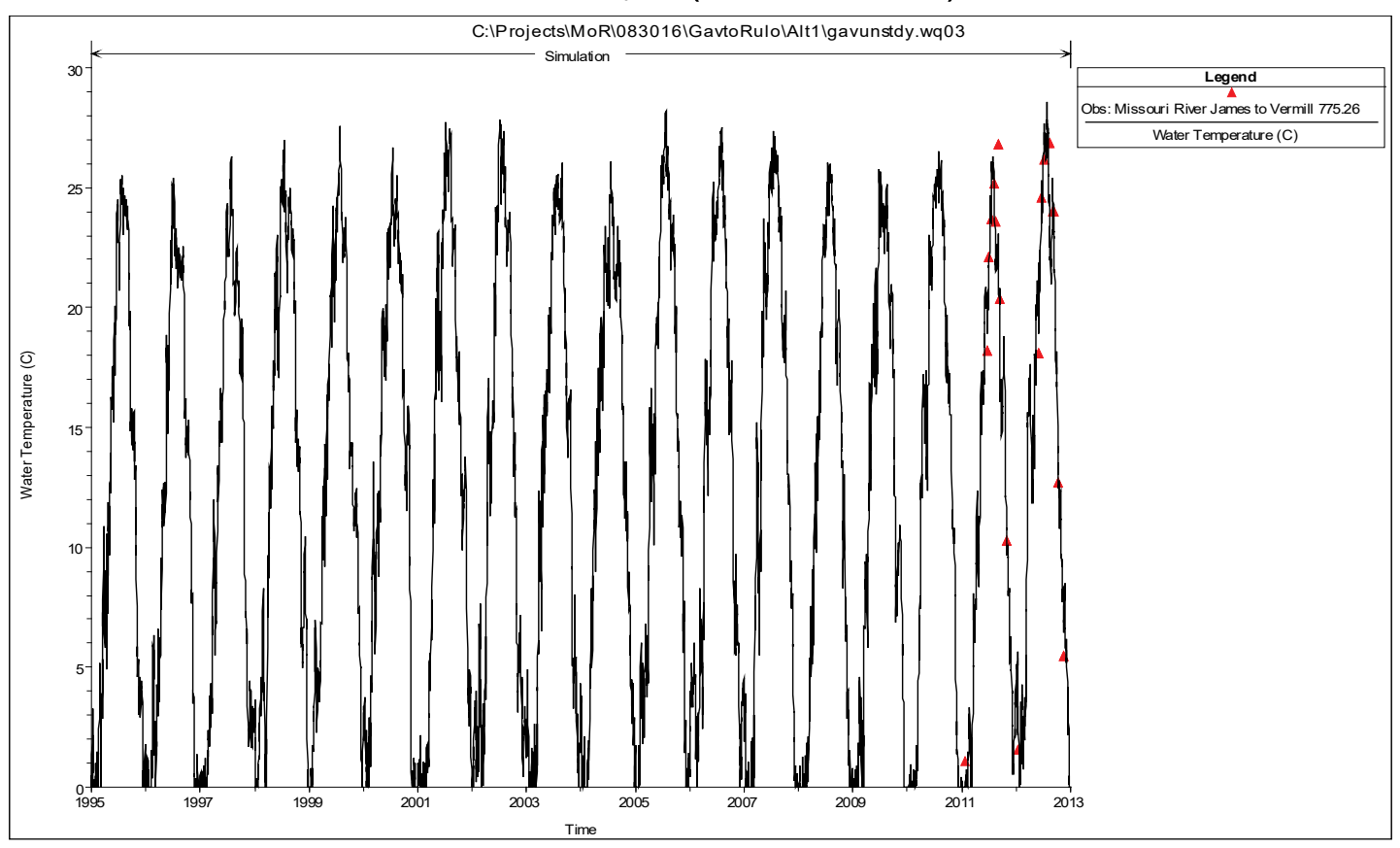

Figure 33. HEC-RAS predicted versus observed water temperatures of the Missouri River at Sioux City, IA (USGS 06486000).

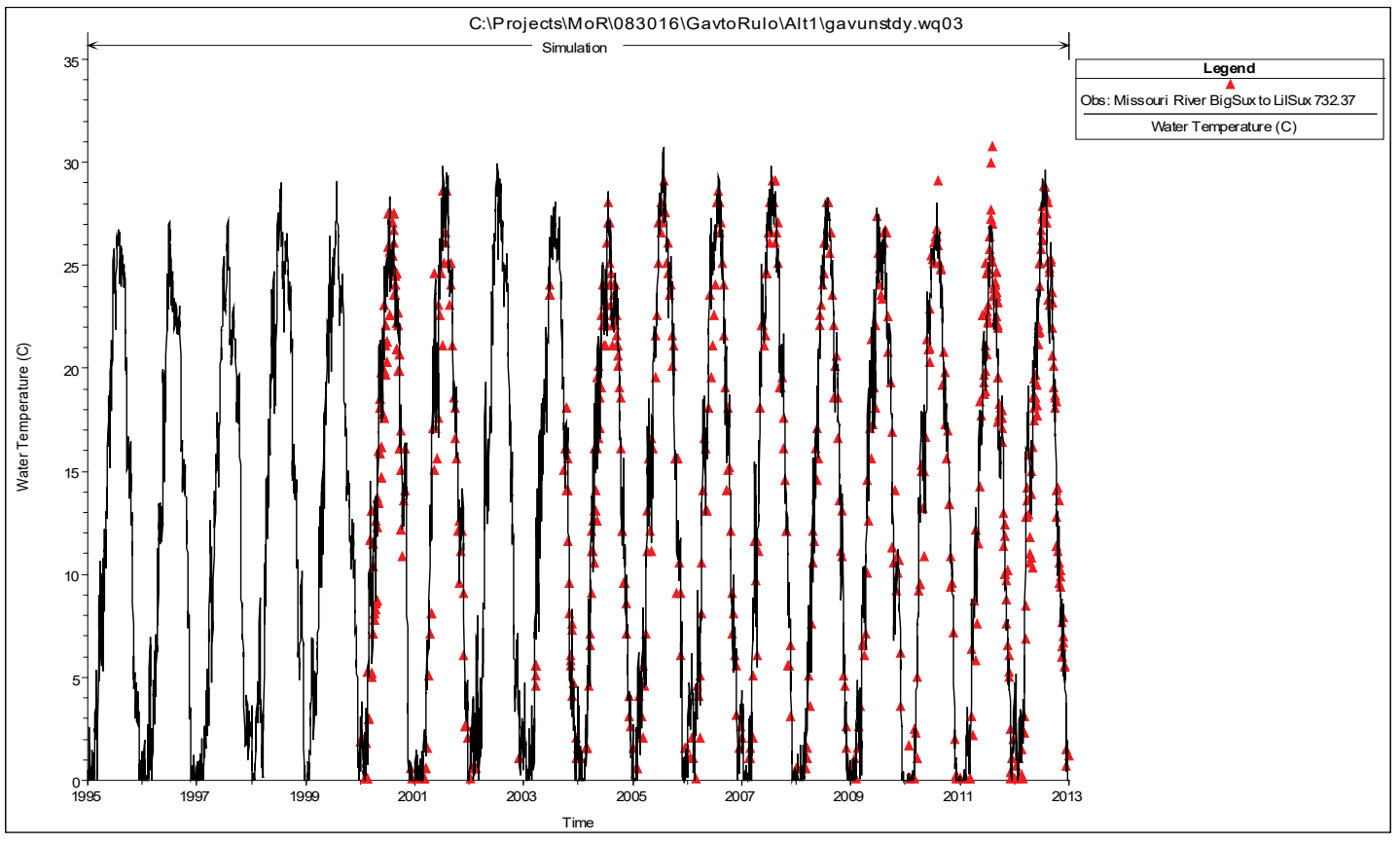


Figure 34. HEC-RAS predicted versus observed water temperatures of the Missouri River at Decatur, NE (USGS 06601200).

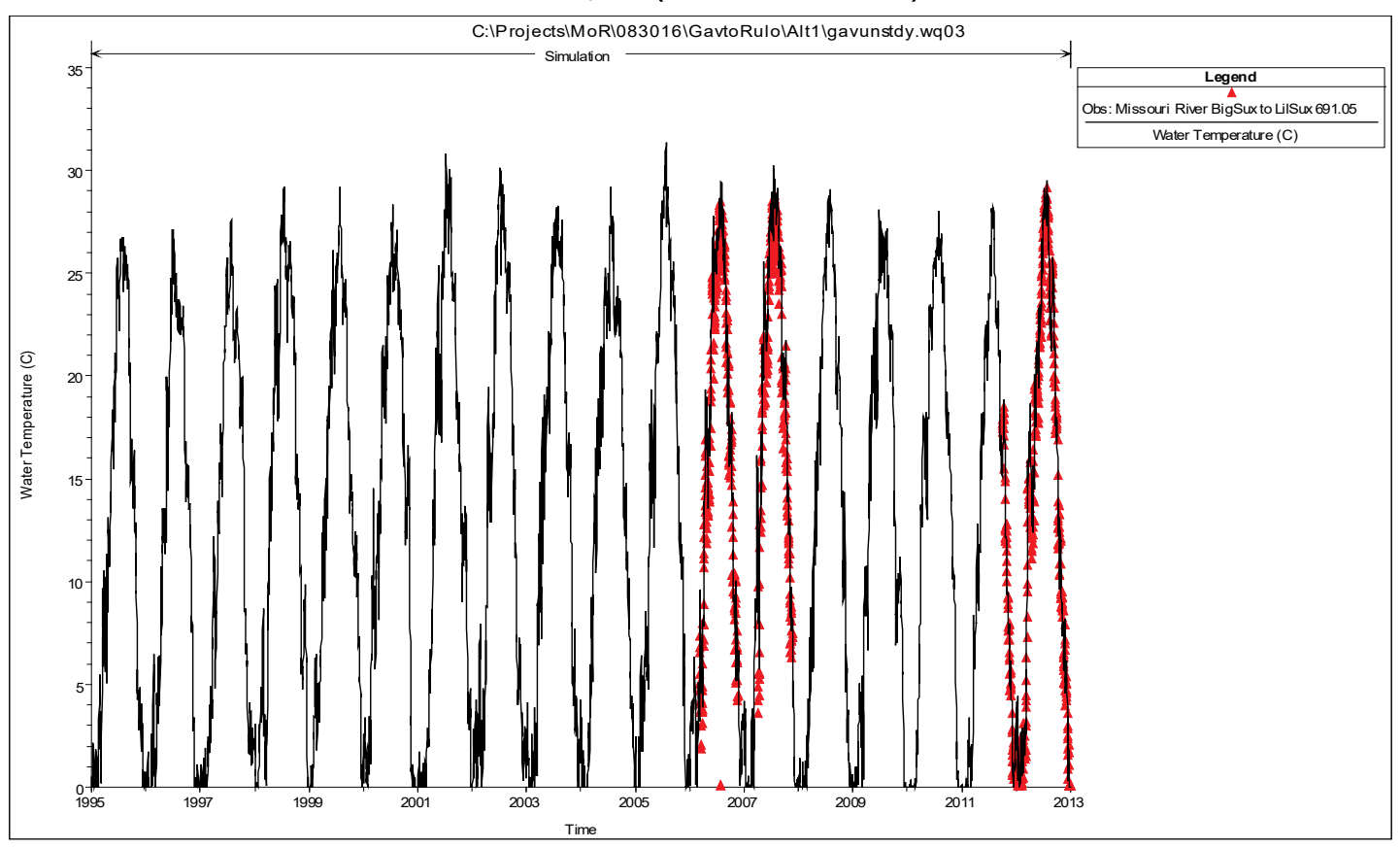

Figure 35. HEC-RAS predicted versus observed water temperatures of the Missouri River at Omaha, NE (USGS 06610000).

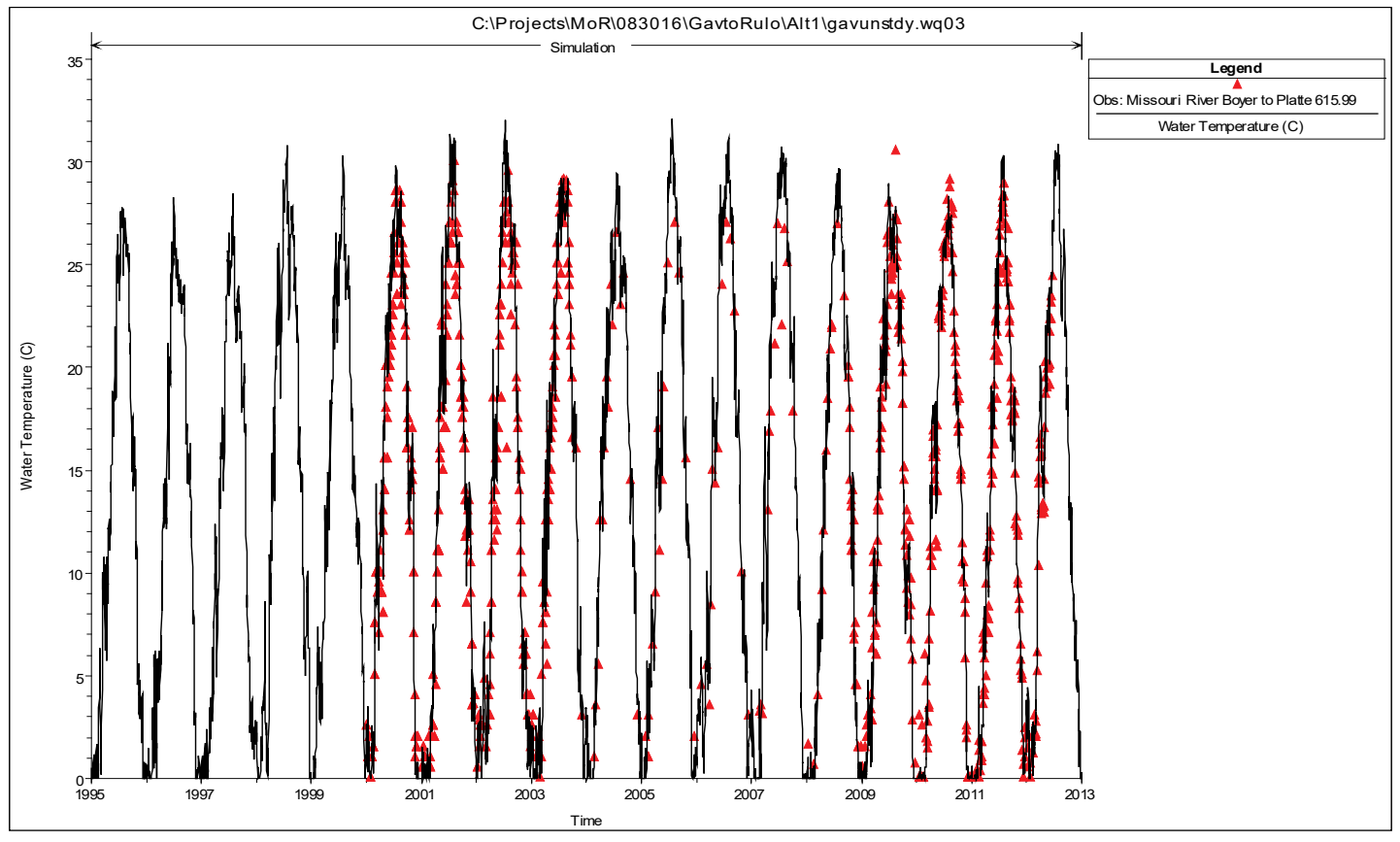


Figure 36. HEC-RAS predicted versus observed water temperatures of the Missouri River at Nebraska City, NE (USGS 06807000).

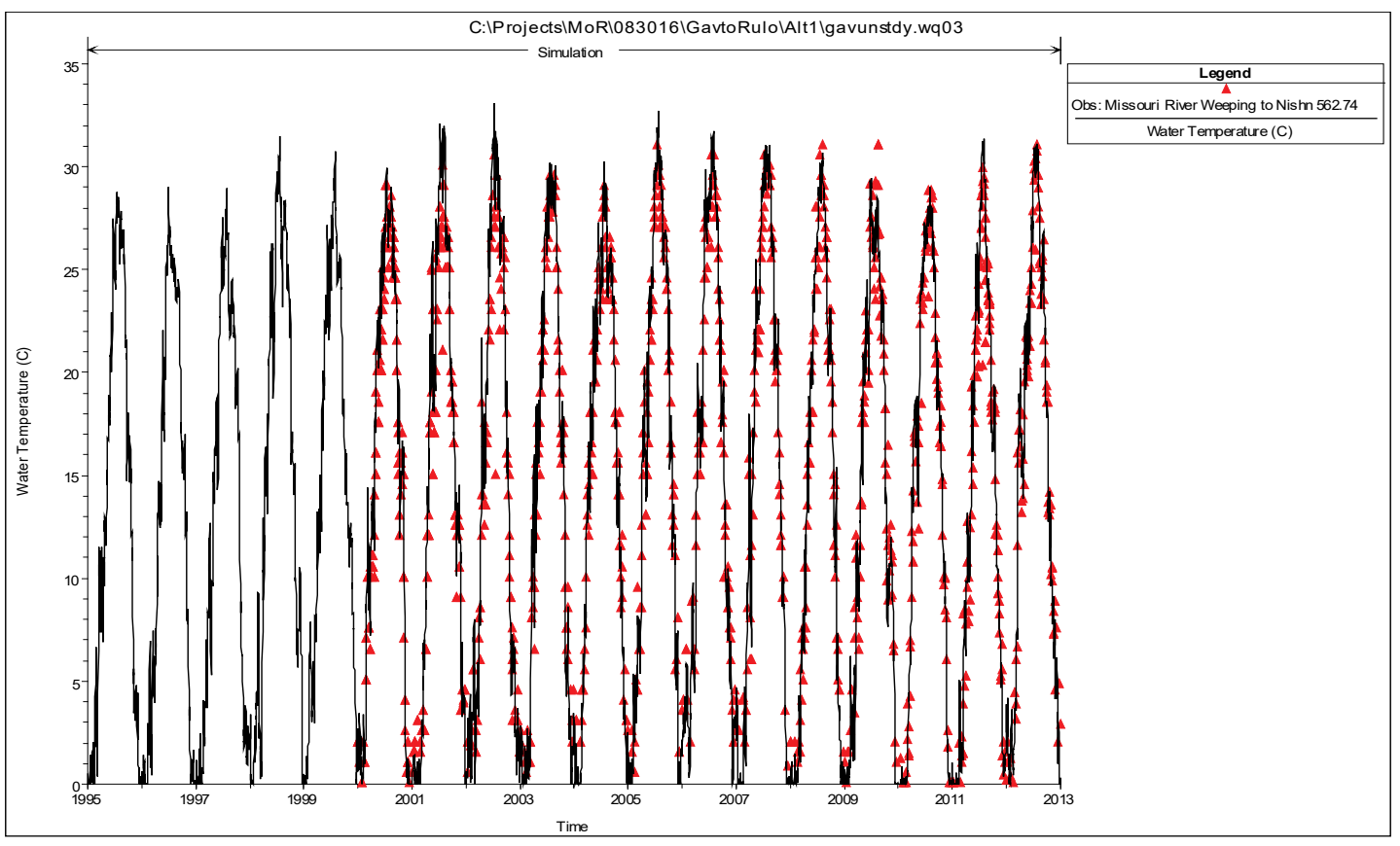

Figure 37. HEC-RAS predicted versus observed water temperatures of the Missouri River at Rulo, NE (USGS 06813500).

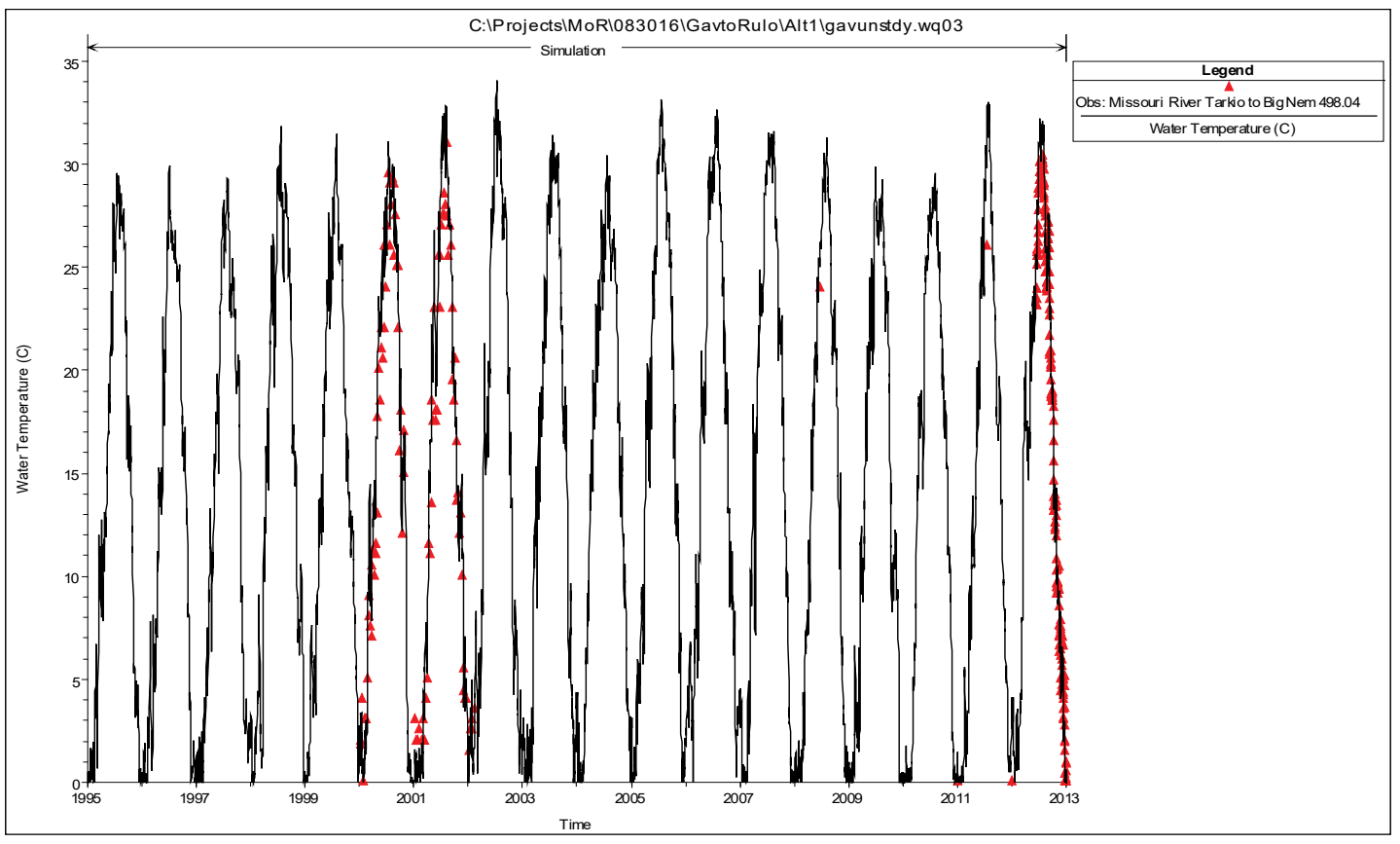

The above time series plots suggest a fairly good agreement between the HEC-RAS predictions and observations for all six calibration locations along this river reach, except that the model tends to over predict the peak water temperatures during summer seasons. 


\subsubsection{Rulo to the Mouth of the Missouri River}

\subsubsection{HEC-RAS flow model}

From the Rulo (Rulo, NE) to the mouth reach of the Missouri River (near St. Louis, MO) is approximately 498 miles. This reach meanders south through the dissected till plaines of the central lowlands to Kansas City, then traverses east along the northern border of the Osage Plains and Ozark Plateau until it empties into the Mississippi River. Major tributaries include the Kansas, Grand, Chariton, Osage, and Gasconade. USACE Kansas City District developed and calibrated the unsteady HEC-RAS flow model for the Rulo to the mouth reach of the Missouri River (USACE 2015). The model extent and tributaries entering the Missouri River within this reach are shown in Figure 38.

Figure 38. HEC-RAS model extent for the Rulo to the Mouth of the Missouri River reach (USACE 2015).

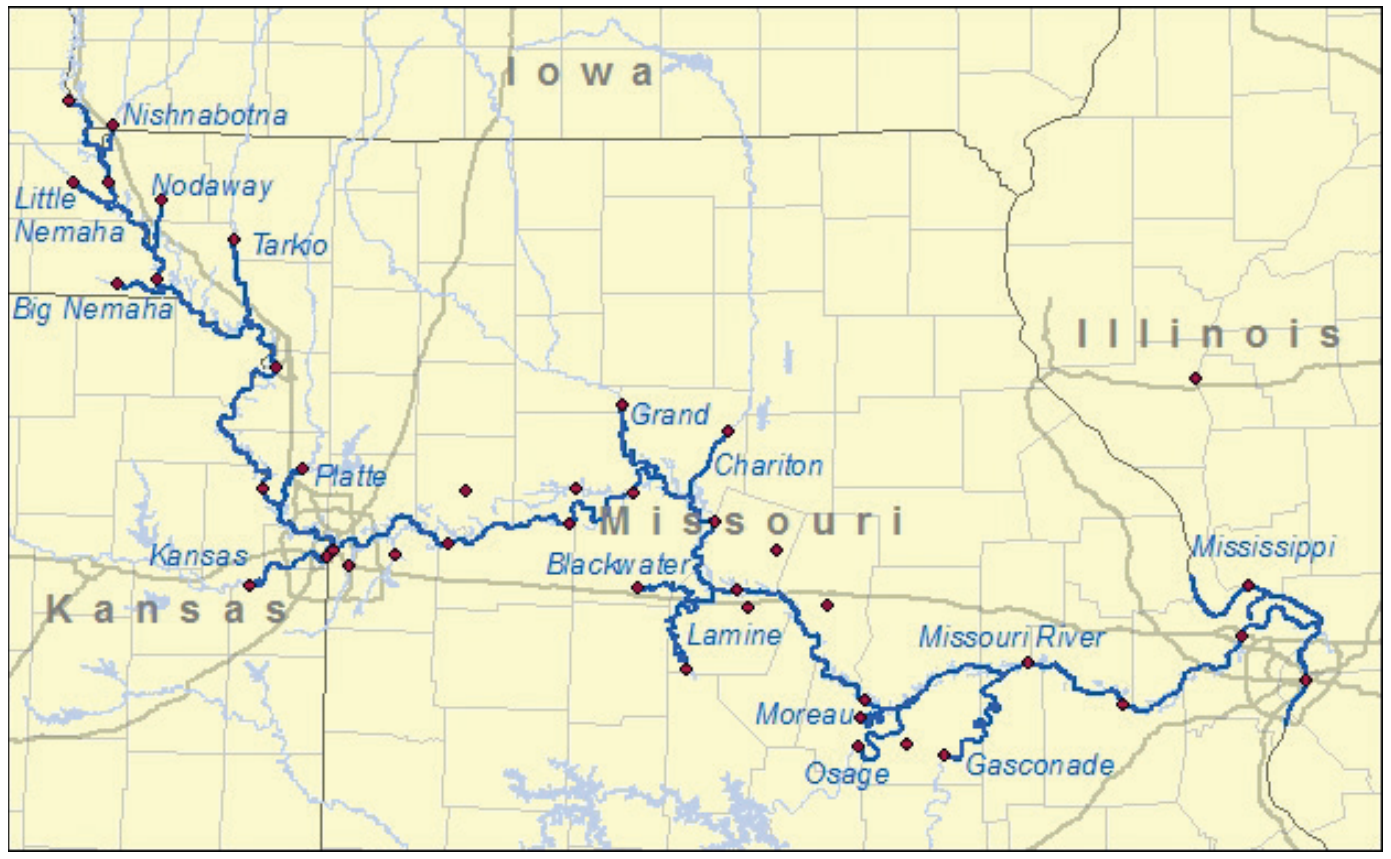

In the HEC-RAS flow model, the model area was extended upstream and downstream because of the complicated nature of modeling extreme floods such as experienced in 1993 and 2011 at both Rulo and the confluence. Approximately 70 miles of the Mississippi River was included, with the upstream limit at the tailwater of Lock and Dam 25 and the downstream boundary approximately 10 miles downstream of the St. Louis USGS gage. Upstream, the model limits of the Missouri River were extended approximately 60 miles to Nebraska City, NE. 
Fourteen tributary reaches were also simulated in the Rulo to the mouth of the Missouri River reach HEC-RAS model. The primary purposes of including tributary reaches were to route flows from the gage to the confluence with the Missouri. Other small tributaries entering the Missouri were specified as lateral inflow boundaries in the HEC-RAS model. In the HEC-RAS model, all ungaged inflow is uniformly distributed between gages based on basin area. Modeled tributaries include:

- Nishnabotna River

- Little Nemaha River

- Tarkio River

- Big Nemaha River

- Nodaway River

- Platte River

- Kansas River

- Grand River

- Chariton River

- Blackwater River

- Moreau River

- Osage River

- Gasconade River

\subsubsection{Water temperature model Inputs}

Meteorological data and inflow temperature boundary conditions for the Rulo to the mouth of the Missouri River reach HEC-RAS model are discussed below.

\section{Meteorological data}

Seven meteorological stations (KSTJ, KCOU, KSTL, KMCI, KMKC, KSUS, KJEF), shown in Figure 1, were used in the Rulo to the mouth of the Missouri River reach of the HEC-RAS water temperature model. In HECRAS, the meteorological data from each station was automatically assigned to water quality computational cells within the river reach based on the closest distance.

\section{Boundary conditions}

Figure 39 presents approximate locations of flow boundaries included in the Rulo to the mouth of the Missouri River reach of the HEC-RAS model. 
Water temperatures associated with each inflow boundary for the simulation period (1995-2012) were computed using the developed regressions as explained previously and specified in the model through a HEC-DSS file. Table 9 lists all water temperature boundaries corresponding to inflow boundaries along this river reach.

Figure 39. Schematic representation of inflow boundary locations included in the HEC-RAS model from Rulo to the mouth of the Missouri River.

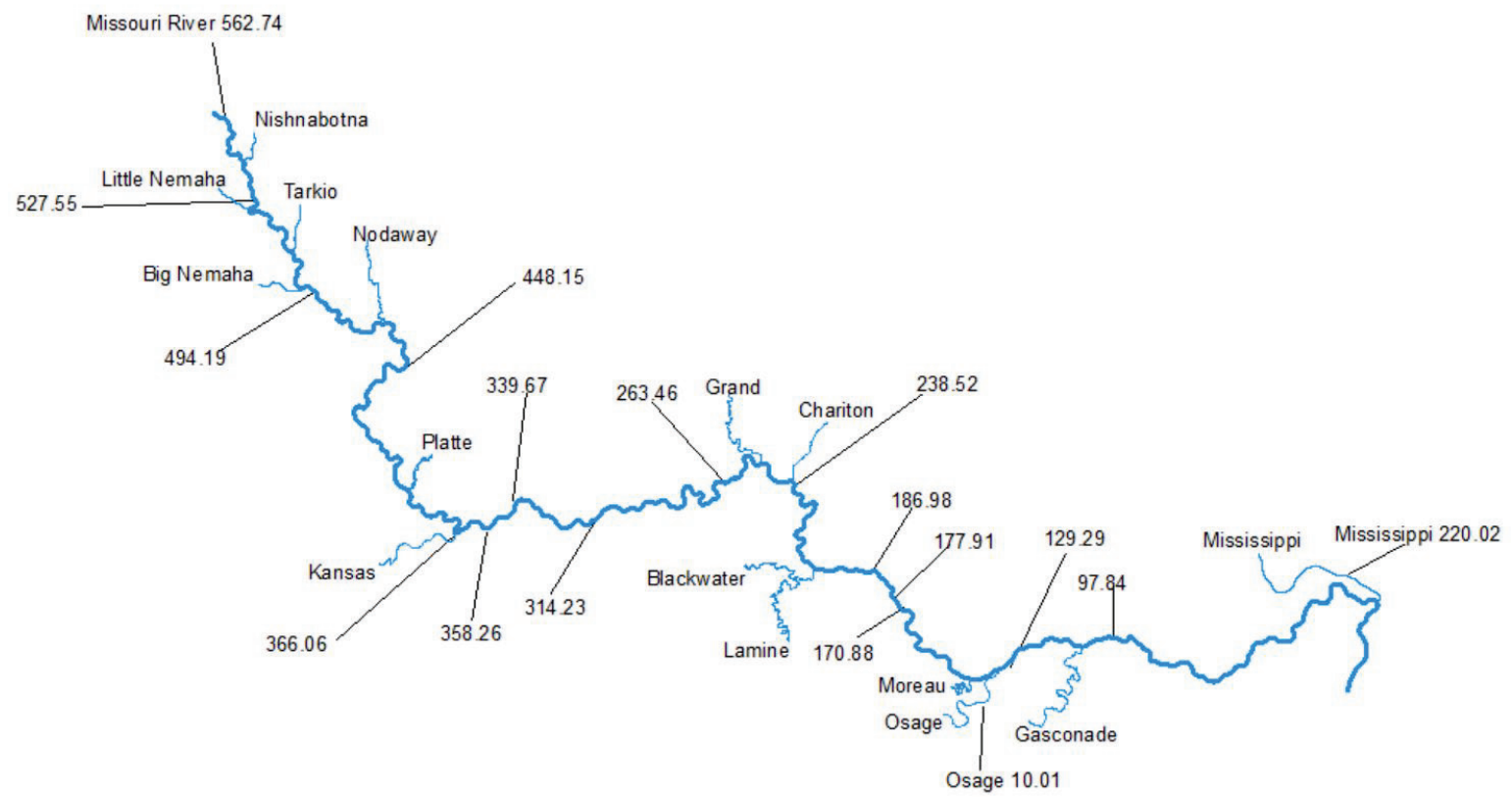

Table 9. Inflow and temperature boundaries included in the HEC-RAS model from Rulo to the mouth of the Missouri River.

\begin{tabular}{|l|l|l|l|}
\hline No & Inflow boundary & Flow boundary type & $\begin{array}{l}\text { Water quality } \\
\text { boundary }\end{array}$ \\
\hline 1 & Big Nemaha River RS 13.66 & Tributary & BC1 \\
\hline 2 & Blackwater River RS 25.77 & Tributary & BC2 \\
\hline 3 & Chariton RS 19.64 & Tributary & BC3 \\
\hline 4 & Gasconade RS 51.64 & Tributary & BC4 \\
\hline 5 & Grand RS 34.87 & Tributary & BC5 \\
\hline 6 & Kansas RS 30.42 & Tributary & BC6 \\
\hline 7 & Lamine RS 56.99 & Tributary & BC7 \\
\hline 8 & Little Nemaha River RS 10.47 & Tributary & BC1 \\
\hline 9 & Mississippi River RS 241.33 & Tributary & BC8 \\
\hline 10 & Mississippi River RS 220.02 & Lateral inflow & BC8 \\
\hline 11 & Missouri River RS 562.74 & Upstream boundary & BC11 \\
\hline
\end{tabular}




\begin{tabular}{|c|c|c|c|}
\hline 12 & Missouri River RS 562.35 & Uniform lateral inflow (withdraw) & \\
\hline 13 & Missouri River RS 541.73 & Uniform lateral inflow (withdraw) & \\
\hline 14 & Missouri River RS 527.55 & Uniform lateral inflow & BC12 \\
\hline 15 & Missouri River RS 527.15 & Uniform lateral inflow (withdraw) & \\
\hline 16 & Missouri River RS 507.49 & Uniform lateral inflow (withdraw) & \\
\hline 17 & Missouri River RS 497.93 & Uniform lateral inflow (withdraw) & \\
\hline 18 & Missouri River RS 494.19 & Uniform lateral inflow & BC13 \\
\hline 19 & Missouri River RS 493.34 & Uniform lateral inflow (withdraw) & \\
\hline 20 & Missouri River RS 462.66 & Uniform lateral inflow (withdraw) & \\
\hline 21 & Missouri River RS 448.15 & Uniform lateral inflow & BC14 \\
\hline 22 & Missouri River RS 448.13 & Uniform lateral inflow (withdraw) & \\
\hline 23 & Missouri River RS 390.57 & Uniform lateral inflow (withdraw) & \\
\hline 24 & Missouri River RS 367.28 & Uniform lateral inflow (withdraw) & \\
\hline 25 & Missouri River RS 366.06 & Uniform lateral inflow & BC15 \\
\hline 26 & Missouri River RS 365.84 & Uniform lateral inflow (withdraw) & \\
\hline 27 & Missouri River RS 358.26 & Lateral inflow & BC15 \\
\hline 28 & Missouri River RS 339.67 & Lateral inflow & BC16 \\
\hline 29 & Missouri River RS 314.23 & Lateral inflow & BC17 \\
\hline 30 & Missouri River RS 293.08 & Uniform lateral inflow (withdraw) & \\
\hline 31 & Missouri River RS 263.46 & Lateral inflow & BC18 \\
\hline 32 & Missouri River RS 249.58 & Uniform lateral inflow (withdraw) & \\
\hline 33 & Missouri River RS 238.52 & Uniform lateral inflow & BC18 \\
\hline 34 & Missouri River RS 238.02 & Uniform lateral inflow (withdraw) & \\
\hline 35 & Missouri River RS 202.24 & Uniform lateral inflow (withdraw) & \\
\hline 36 & Missouri River RS 196.54 & Uniform lateral inflow (withdraw) & \\
\hline 37 & Missouri River RS 186.98 & Lateral inflow & BC19 \\
\hline 38 & Missouri River RS 177.91 & Lateral inflow & $\mathrm{BC} 20$ \\
\hline 39 & Missouri River RS 170.88 & Lateral inflow & $\mathrm{BC} 20$ \\
\hline 40 & Missouri River RS 137.24 & Uniform lateral inflow (withdraw) & \\
\hline 41 & Missouri River RS 129.29 & Uniform lateral inflow & $\mathrm{BC} 21$ \\
\hline 42 & Missouri River RS 128.76 & Uniform lateral inflow (withdraw) & \\
\hline 43 & Missouri River RS 103.86 & Uniform lateral inflow (withdraw) & \\
\hline 44 & Missouri River RS 97.84 & Uniform lateral inflow & $\mathrm{BC} 22$ \\
\hline 45 & Missouri River RS 97.37 & Uniform lateral inflow (withdraw) & \\
\hline
\end{tabular}




\begin{tabular}{|l|l|l|l|}
\hline 46 & Moreau River RS 21.04 & Tributary & BC23 \\
\hline 47 & Nishnabotna RS 11.68 & Tributary & BC24 \\
\hline 48 & Nodaway RS 28.91 & Tributary & BC25 \\
\hline 49 & Osage RS 33.62 & Tributary & BC26 \\
\hline 50 & Osage RS 10.01 & Lateral inflow & BC26 \\
\hline 51 & Platte River RS 24.57 & Tributary & BC27 \\
\hline 52 & Tarkio River RS 13.56 & Tributary & BC8 \\
\hline
\end{tabular}

\subsubsection{Water temperature model set up and calibration}

The HEC-RAS temperature model from Rulo to the mouth of the Missouri River was set up and run using an hourly time step from January 1, 1995December 31, 2012. Figure 40 shows the schematic and data plan of the HEC-RAS temperature model for this reach. The minimum water quality cell length in HEC-RAS was set as $1000 \mathrm{ft}$.

Figure 40. Schematic and data plan of the HEC-RAS temperature model for the Rulo to the Mouth of the Missouri River.

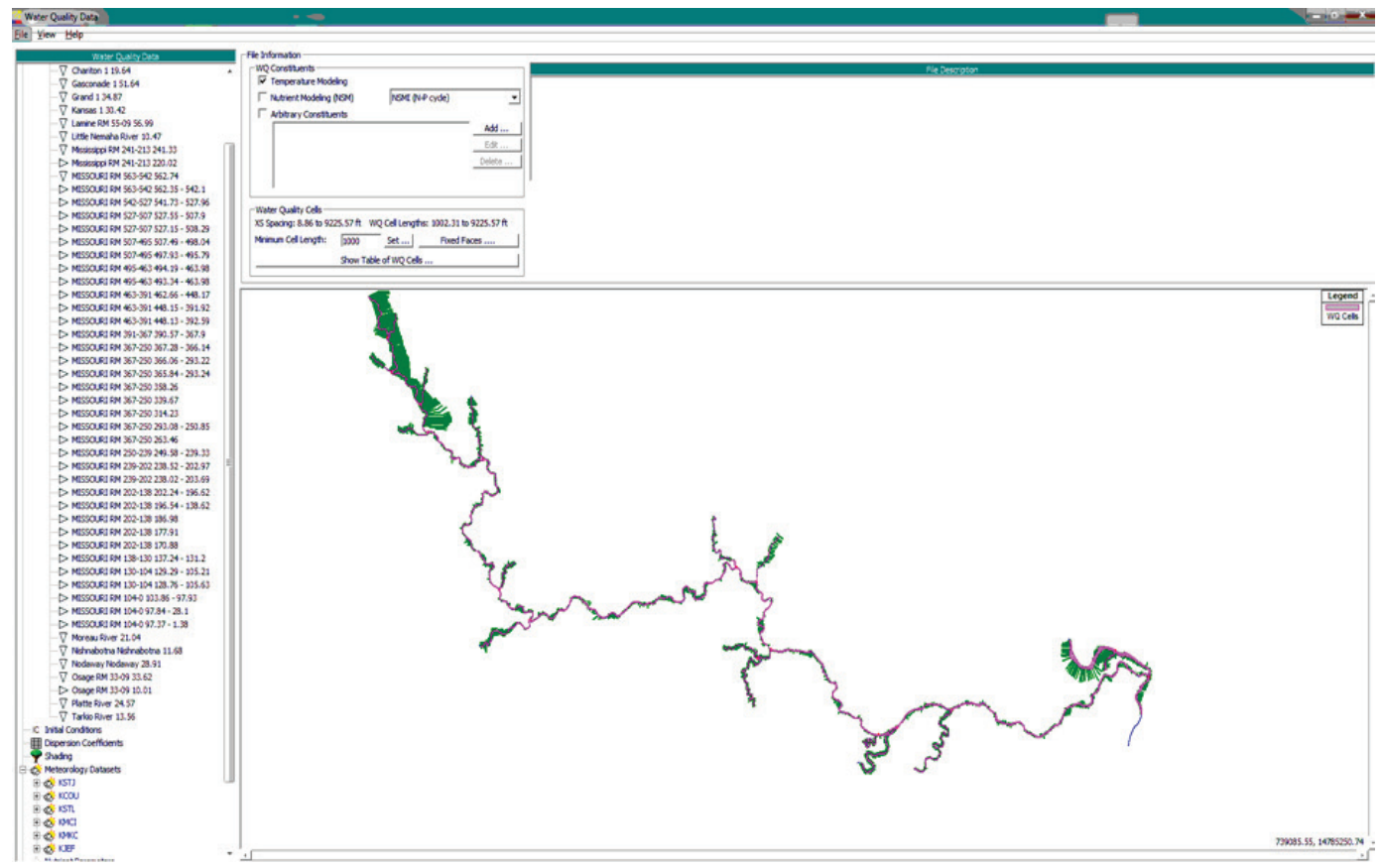

The water temperature model calibration primarily focused on five USGS stations with limited observed data along this reach. These five USGS stations are 06818000, 06893000, 06895500, 06906500, and 06934500. Their locations on the main stem Missouri River can be found in Figure 31. Time series plots of HEC-RAS modeled and observed data are presented in 
Figures 41-45. These figures show the comparison of HEC-RAS predicted and observed mean daily stream temperatures.

Figure 41. HEC-RAS predicted versus observed water temperatures of the Missouri River at St. Joseph, MO (USGS 06818000).

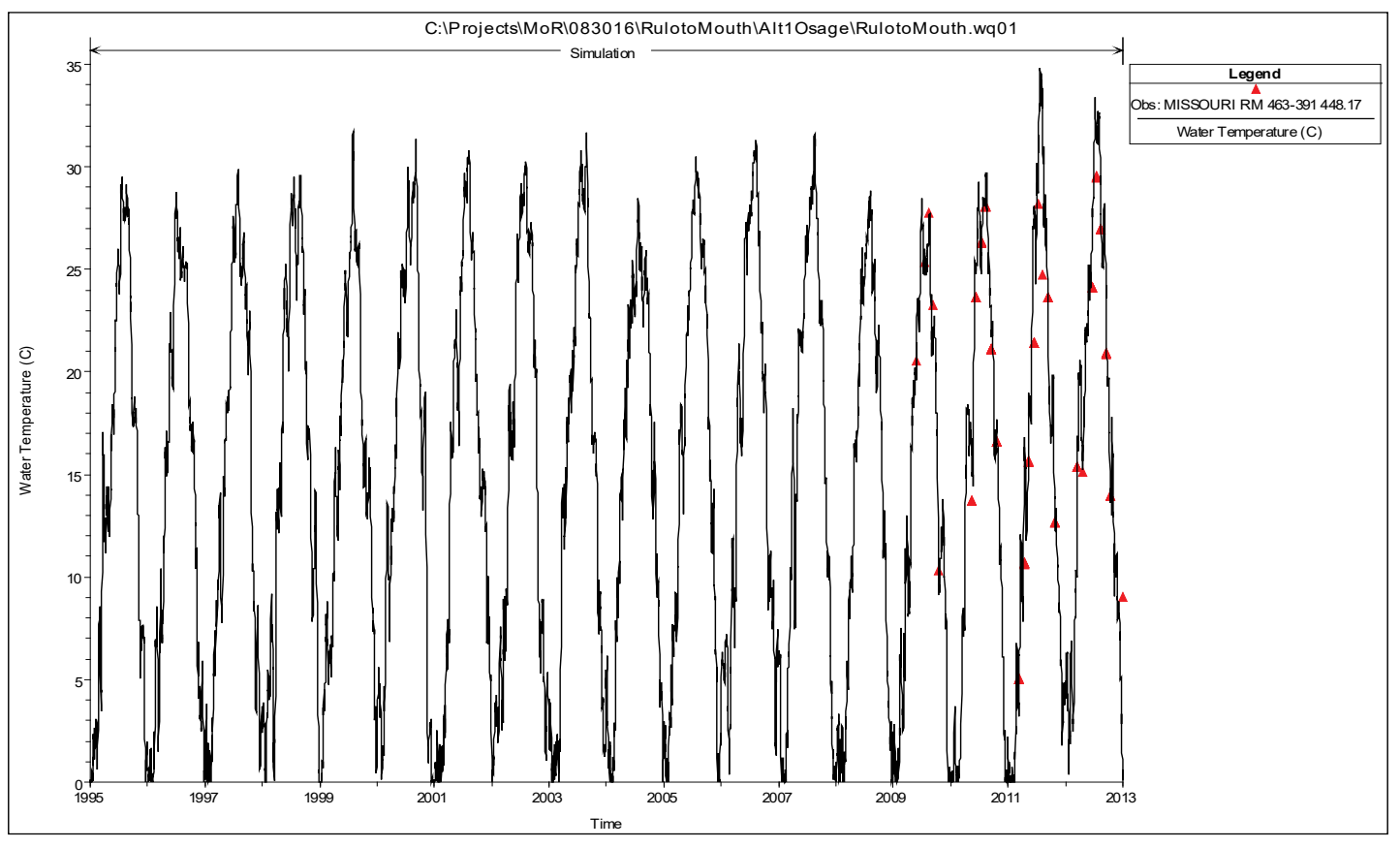

Figure 42. HEC-RAS predicted versus observed water temperatures of the Missouri River at Kansas City, MO (USGS 06893000).

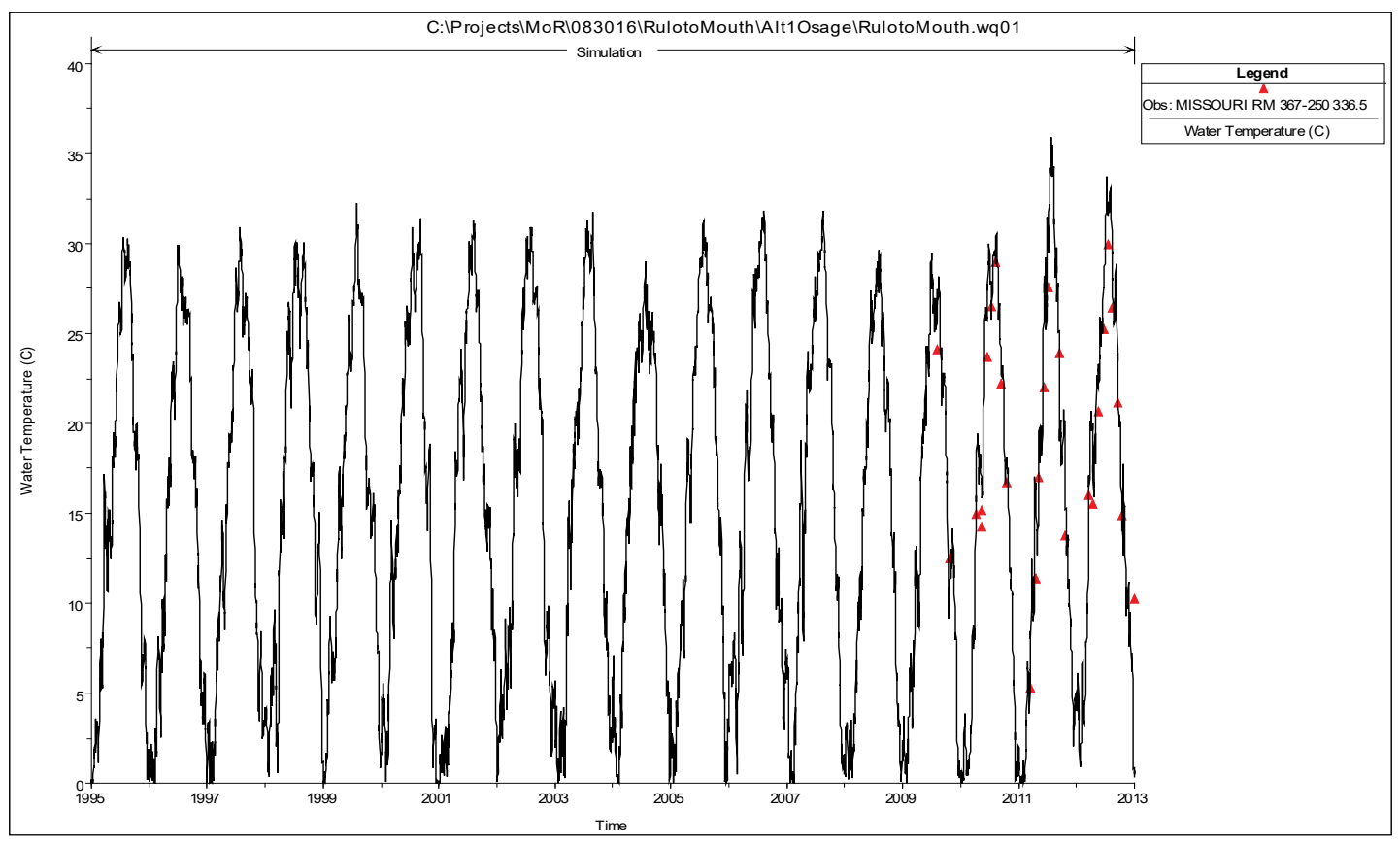


Figure 43. HEC-RAS predicted versus observed water temperatures of the Missouri River at Waverly, MO (USGS 06895500).

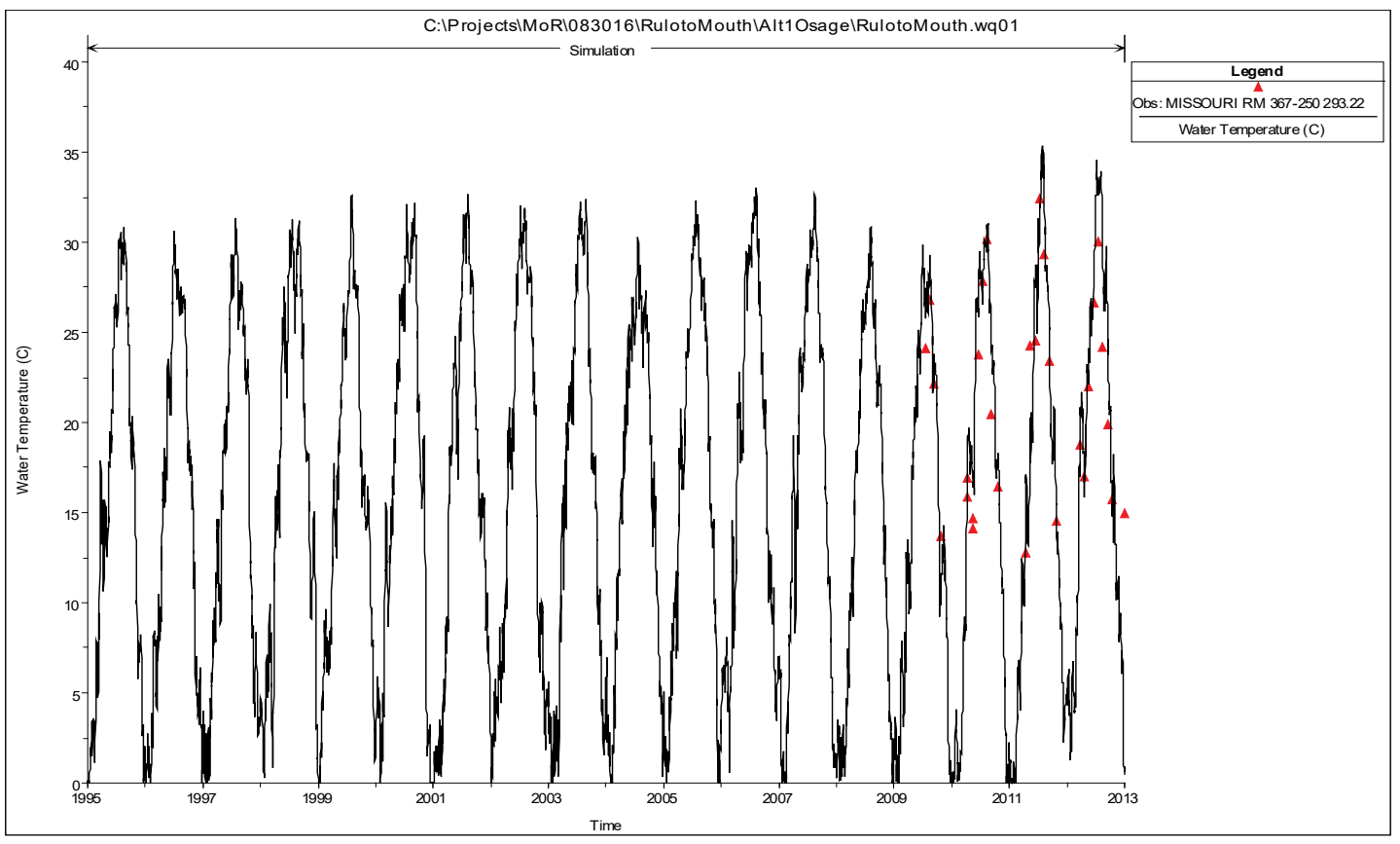

Figure 44. HEC-RAS predicted versus observed water temperatures of the Missouri River at Gasgow, MO (USGS 06906500).

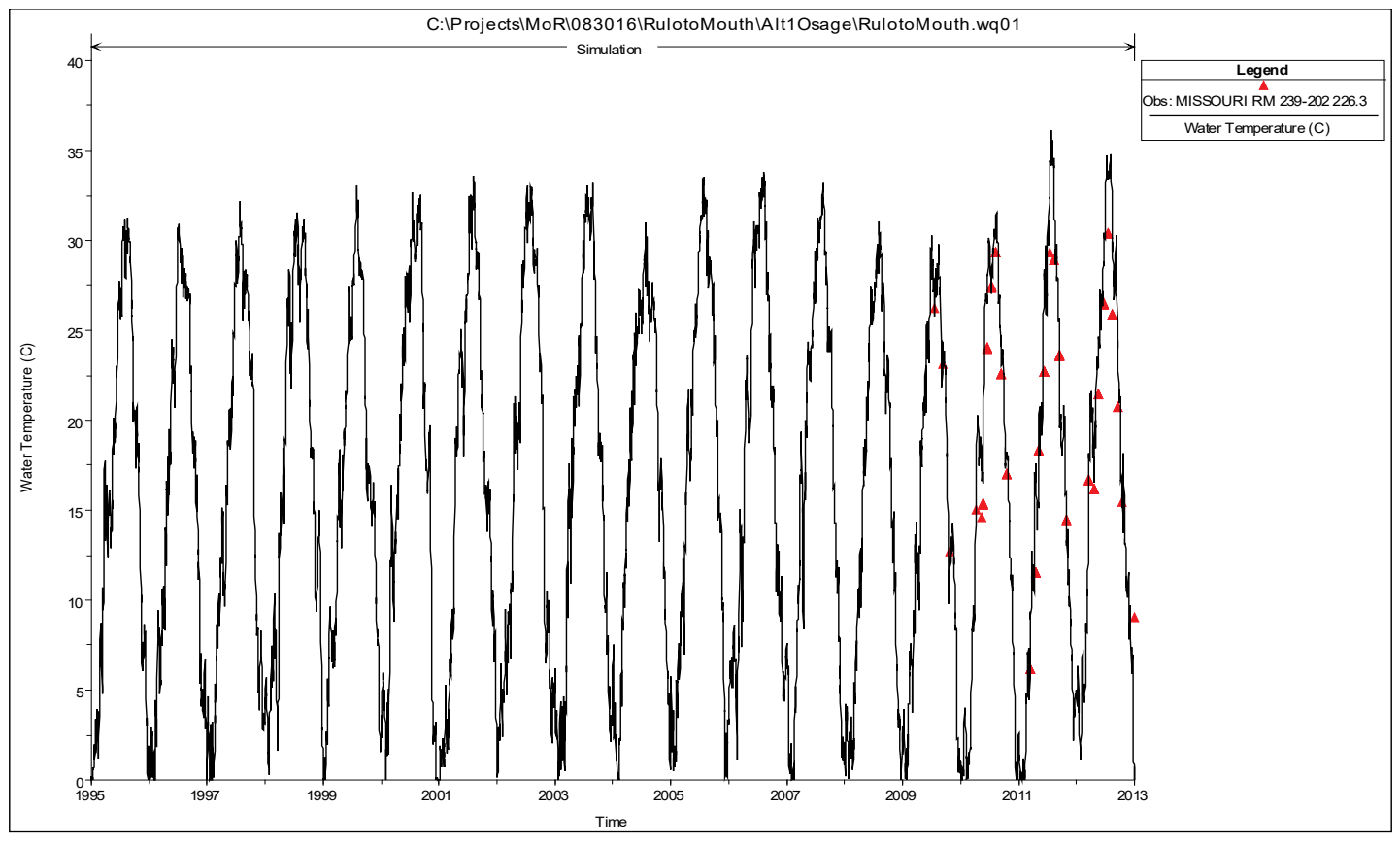


Figure 45. HEC-RAS predicted versus observed water temperatures of the Missouri River at Hermann, MO (USGS 06934500).

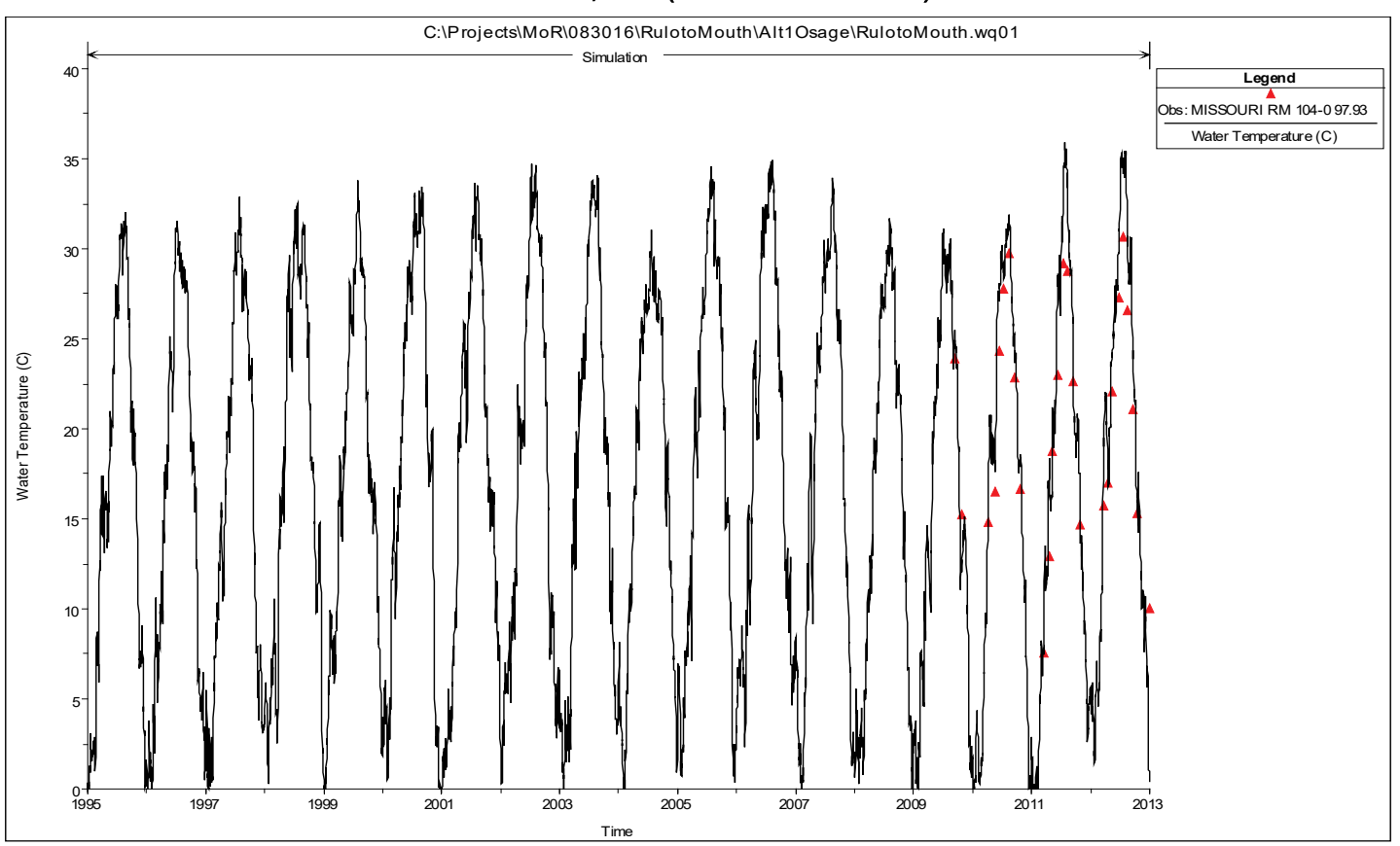

The above time series plots suggest a fairly good agreement between the HEC-RAS predictions and observations for five calibration locations, except that the model tends to over predict the peak water temperatures during summer seasons.

In summary, HEC-RAS water temperature models described above were preliminarily calibrated due to limited observed data and approximate boundary conditions. The sources of model uncertainty originate from the accuracy and temporal resolution of inflow water temperature boundary conditions included in the HEC-RAS models. Several water temperature boundary conditions computed from the regression relationships are quite uncertain due to limited observed data and use of air temperature as the only independent variable in developed regression relationships in this chapter. Additionally, water temperature model uncertainty also comes from the scarcity of stream water quality monitoring gages within the basin and the limited record available at these gages. Most water quality sample measurements for this study were obtained monthly during the summer. Additional observed water temperature data are necessary to improve and refine Missouri River HEC-RAS water temperature models described here. 


\section{Missouri River HEC-RAS Water Temperature Model Results for Alternatives}

This chapter briefly describes the ManPlan and EIS alternatives (scenarios) USACE provided for use in three reach HEC-RAS water temperature models. These three river reaches are Garrison Dam to Oahe Dam, Gavins Point Dam to Rulo, and Rulo to the mouth of the Missouri River. The HEC-RAS water temperature results for each reach and each alternative were stored in their corresponding HEC-DSS files and provided to the project team.

Alternatives evaluated in the ManPlan and EIS were informed by the best available science and shaped through collaboration among the USACE, USFWS, and the Missouri River Recovery Implementation Committee (MRRIC). The alternatives are collections of management actions aimed at providing habitat conditions to avoid a finding of jeopardy for the three listed species. Detailed description of the alternatives is provided in Draft Missouri River Recovery Management Plan and Environmental Impact Statement (USACE 2016). Table 10 provides a list of recently developed ManPlan and EIS alternatives conducted with the existing HEC-RAS flow models.

Table 10. List of alternatives evaluated with the Missouri River HEC-RAS models.

\begin{tabular}{|l|l|}
\hline Alt & \multicolumn{1}{|c|}{ Geometry } \\
\hline 1 & $\begin{array}{l}\text { No Action (Year 2012) } \\
\text { (2012 geometry + new Shallow Water Habitat (SWH) + mechanical } \\
\text { Emergent Sandbar Habitat (ESH) }\end{array}$ \\
\hline 2 & $\begin{array}{l}\text { Biological Opinion of the U.S. Fish and Wildlife Service (BiOp) As Projected } \\
\text { (Year 2012) } \\
(2012 \text { geometry + USFWS SWH/ESH/Inundation/Bi-modal Pulse) }\end{array}$ \\
\hline 3 & $\begin{array}{l}\text { All Mechanical (Year 2012) } \\
(2012 \text { geometry + new Interception Rearing Complex (IRC) + mechanical } \\
\text { ESH) }\end{array}$ \\
\hline 4 & $\begin{array}{l}\text { Spring 2, 42 MAF (Year 2012) } \\
(2012 \text { geometry + new IRC + Spring Bird ESH Release + mechanical ESH) }\end{array}$ \\
\hline 5 & $\begin{array}{l}\text { Fall 5, 35 SL (Year 2012) } \\
(2012 \text { geometry + new IRC + Fall Bird ESH Release + mechanical ESH) }\end{array}$ \\
\hline 7 & $\begin{array}{l}\text { Spawning cue (Year 2012) } \\
(2012 \text { geometry + new IRC + Bi-modal spawning cue + mechanical ESH) }\end{array}$ \\
\hline
\end{tabular}


USACE Omaha and Kansas City Districts developed the HEC-RAS flow models for each river reach as well as each alternative. When constructing corresponding HEC-RAS water temperature models for three river reaches (e.g., Garrison Dam to Oahe Dam, Gavins Point Dam to Rulo, and Rulo to the mouth of the Missouri River) and all alternatives listed in Table 10, the following assumptions were made:

- The HEC-RAS flow models for each river reach and all alternatives, were run in conjunction with the same historical meteorological and water temperature boundary forcings (1995-2012).

- Water quality parameters that were calibrated in the baseline HECRAS water temperature model for each reach were not adjusted while conducting alternative model runs.

The HEC-RAS water temperature models for each river reach and each alternative were then employed to compute the daily mean water temperatures for the 18-year $\left(1995^{-2012}\right)$ simulation period. The water temperature results at specified locations of the Missouri River (Table 11) were written into a HEC-DSS file for each reach and each alternative.

Table 11. List of HEC-RAS water temperature model output locations along the Missouri River.

\begin{tabular}{|l|l|}
\hline River Mile (RM) & Location \\
\hline \multicolumn{2}{|c|}{} \\
\hline 57.85 & Rulo to the mouth of the Missouri River reach \\
\hline 115.39 & Labadie Power Plant, Labadie, MO \\
\hline 336.50 & KCP\&L Sibley Power Station, Sibley, MO \\
\hline 345.67 & Independence, MO Power (decommissioned 1/2016) \\
\hline 358.26 & KCP\&L Hawthorne Power Station, Kansas City, MO \\
\hline 365.84 & Veolia Energy Grand Ave-summer PKG \\
\hline 373.45 & Quindaro Power Station, Kansas City, KS \\
\hline 378.84 & $\begin{array}{l}\text { Nearman Creek Power Station, Nearman Creek Power Station, } \\
\text { Kansas City, KS }\end{array}$ \\
\hline 410.70 & KCPL-latan Power Station, Latan, MO \\
\hline 445.88 & KCP\&L St.Joseph-Lake Road Power Station, St Joseph, MO \\
\hline & \multicolumn{2}{|c|}{ Gavins Point Dam to Rulo reach } \\
\hline 532.50 & NPPD-Cooper Nuclear Power Plant, Brownville, NE \\
\hline
\end{tabular}




\begin{tabular}{|l|l|}
\hline 556.37 & OPPD-Power Plant, Nebraska City, NE \\
\hline 605.86 & MidAmerican -- Walter Scott Energy Center, Council Bluffs, IA \\
\hline 625.22 & OPPD-No.Omaha Power Station \\
\hline 645.99 & OPPD-Ft.Calhoun Nuclear Power Plant, Council Bluffs, IA \\
\hline 716.83 & Neal South-Unit 4 (MidAmerican), Sioux City, IA \\
\hline 718.44 & Neal North-Unit 1-3 (MidAmerican), Sioux City, IA \\
\hline \multicolumn{1}{|c|}{ Garrison Dam to Oahe Dam reach } \\
\hline 1319.46 & Montana Dakota Utilities Heskett \\
\hline 1362.68 & Great River Energy-Coal Creek \\
\hline 1364.56 & Minnkota Power-Milton Young (Square Butte Electric) \\
\hline 1371.83 & $\begin{array}{l}\text { Basin Electric-Leland Olds Station and Great River Energy } \\
\text { Stanton Station }\end{array}$ \\
\hline 1372.38 & Montana Dakota Utilities Coyote \\
\hline
\end{tabular}

The HEC-RAS model predicted water temperatures stored in the HECDSS files can be used to produce a baseline condition (no action condition) against which alternatives will be assessed. As an illustration, Figure 46 shows the over 18-year time series plots of HEC-RAS model predicted daily flow at Missouri River RM 625.22 for alternatives 1 and 7. Figure 47 shows a comparison of HEC-RAS model predicted daily mean water temperatures at this location for alternatives 1 and 7 . Local flow changes do not affect water temperature very much at this location under Alternative 7. The project team has assessed the potential impacts associated with each of the alternatives and the findings are discussed in technical reports available at www.moriverrecovery.org. 
Figure 46. Model predicted daily mean flow discharge at Missouri River RM 625.22 for alternatives 1 and 7.

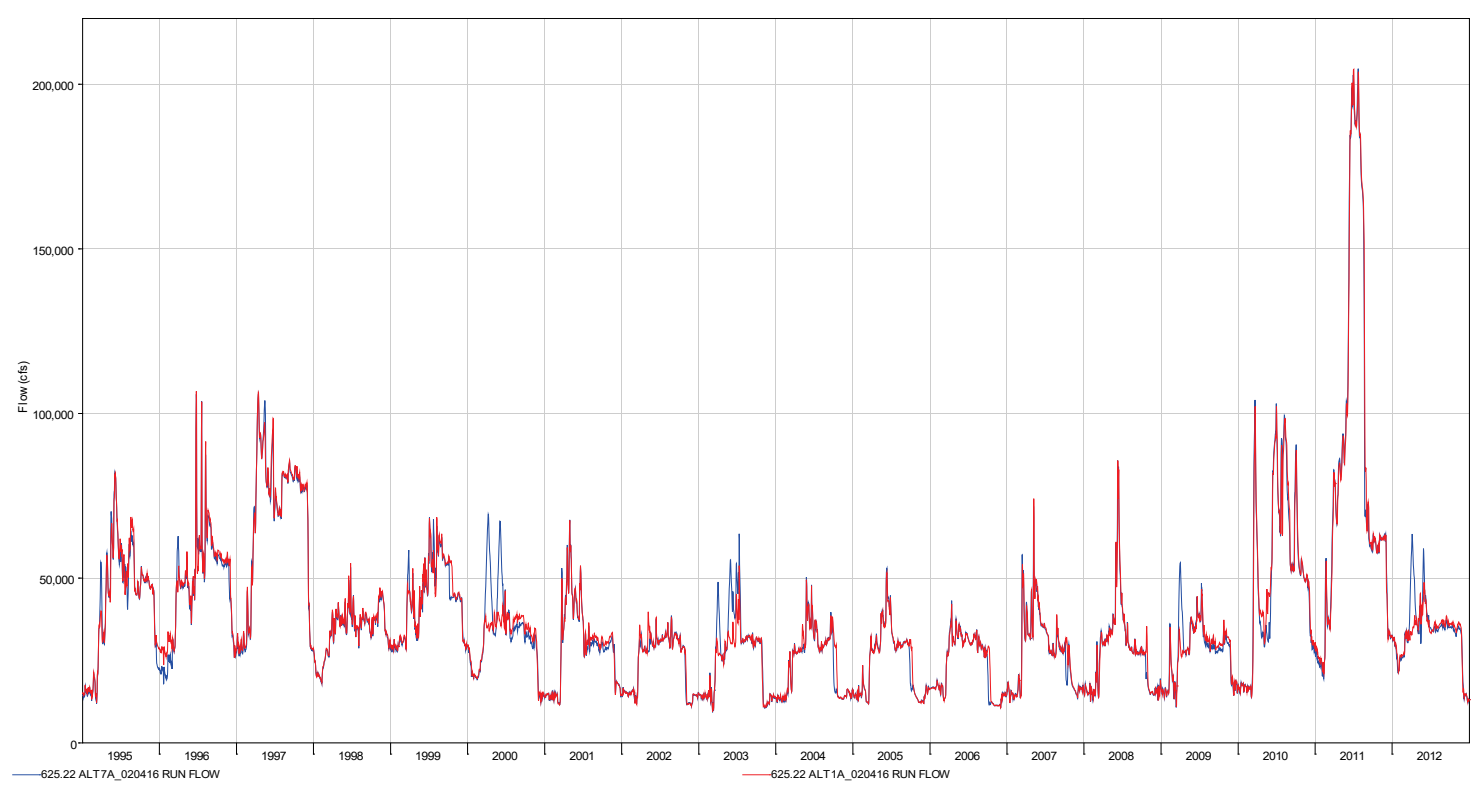

Figure 47. Model predicted daily mean water temperatures at Missouri River RM 625.22 for alternatives 1 and 7.

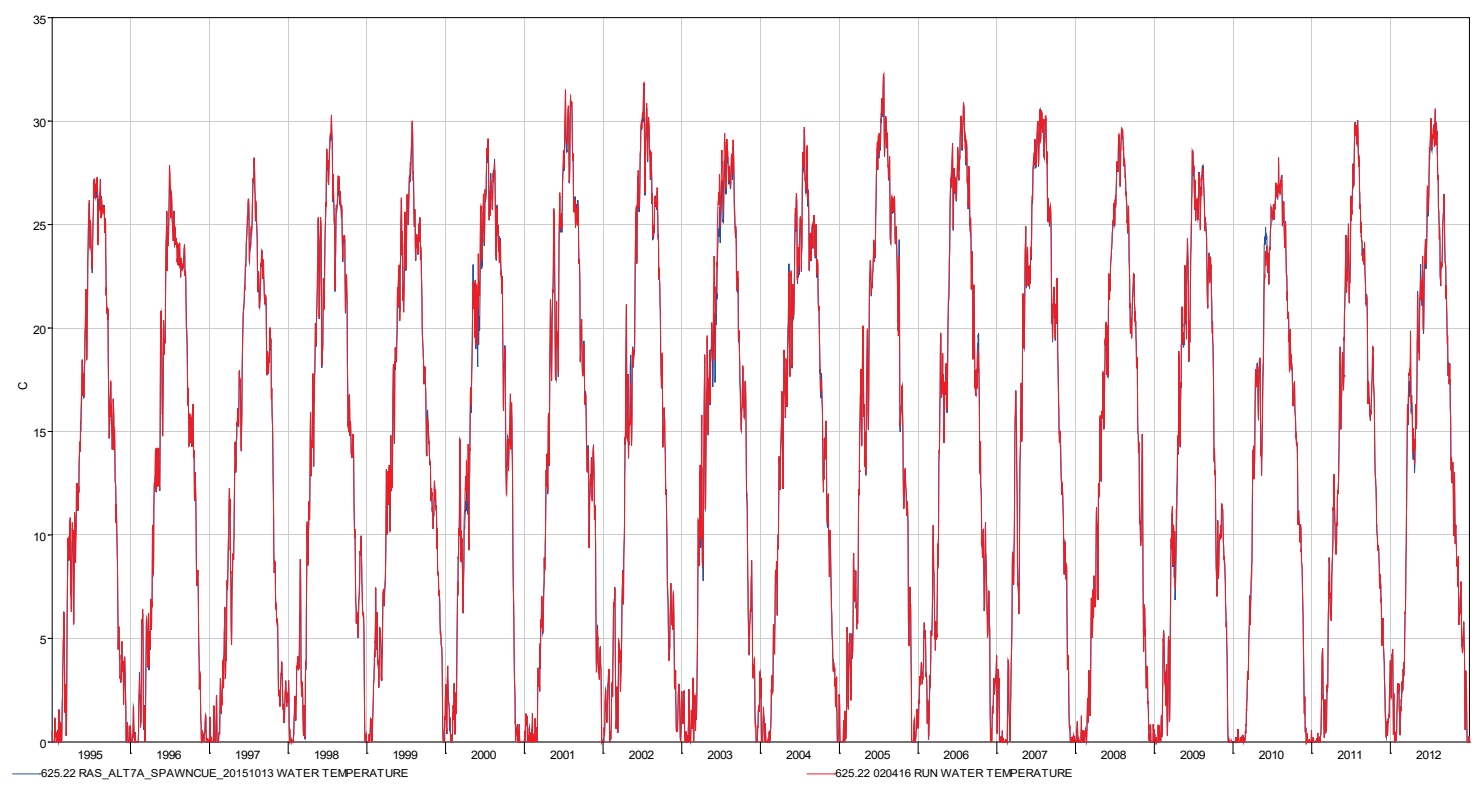




\section{Conclusions and Summary}

The HEC-RAS water temperature models for five reaches of the Missouri River (e.g., Fort Peck Dam to Garrison Dam, Garrison Dam to Oahe, Fort Randall Dam to Gavins Point Dam, Gavins Point Dam to Rulo, and Rulo to the mouth of the Missouri River) were developed and calibrated using available observed data. Of five models, multiple linear regression relationships of air-water temperatures were developed and used to compute long-term inflowing water temperature boundary conditions for three HEC-RAS models (e.g., Garrison Dam to Oahe, Gavins Point Dam to Rulo, and Rulo to the mouth of the Missouri River). The HEC-RAS water temperature models for these three reaches were set up and run from January 1, 1995-December 31, 2012, and the model results for three river reaches were used in support of conducting current ManPlan and EIS analysis.

In this study, various factors contributed to model error for water temperature predictions in the HEC-RAS models. The largest sources of model input uncertainty contributing to model error were the accuracy and temporal resolution of inflow water temperature boundary conditions. Water temperature boundary conditions computed from regression relationships showed errors because of limited observed data and the bestfit regression equation, which uses only air temperature as the single independent variable for predicting water temperature. Observed data sets used for each reach only covered the period 2009-2012. Additionally, most of the water temperature measurements were conducted monthly during the summer. These data limitations can certainly impact the accuracy of computed water temperatures.

Since this study is a work in progress, the following recommendations are provided for future model updates and improvement. Inflow water temperature predictions can be improved when watershed hydrology is incorporated into the model; thus, a basin wide watershed model is especially useful for generating accurate boundary conditions where varying inflow components propel differences in stream temperatures, and a lack of sufficient data is observed. Furthermore, watershed models that simulate the influence of all hydrologic sources (e.g., snowmelt, groundwater inflow, surface runoff, and stream discharge) and water quality together possess the capability to project the effects of hydrologic changes on stream temperature. 
The existence of point sources along the Missouri River may have significant effects on stream temperatures. Flow boundary conditions for wastewater treatment plants and other industries discharging into the Missouri River were grouped together as ungaged flow in the current HEC-RAS flow models. Ungaged inflow represents that portion of the flow that is not captured by the gage station records, and then is calculated within HEC-RAS. Thus, point source flows and temperatures were not specified in the HEC-RAS models. It is recommended that all major point sources should be included as inflow boundary conditions in the Missouri River HEC-RAS models.

Due to the limited observed water temperature data available for this study, additional data should be collected for all inflow tributaries and the main stem Missouri River. Once additional observed data are available, regression relationships and boundary conditions for the HEC-RAS models can be improved and refined. Missouri River HEC-RAS water temperature model results will be updated with improved data sets. 


\section{References}

Chen, G., and X. Fang. 2015. Accuracy of hourly water temperatures in rivers calculated from air temperatures. Water 7(3): 1068-1087.

Deas, M. L., and C. L. Lowney. 2000. Water temperature modeling review: Central Valley. Central Valley, CA: California Water Modeling Forum.

Erickson, T. R. and H. G. Stefan. 2000. Linear air/water temperature correlations for streams during open water periods. Journal of Hydrologic Engineering 5(3):

317-321.

Fischenich, C. J., J. Tripe, D. Meier, D. Pridal, S. Gibson, J. Hickey, T. Econopouly. 2014. Models, data and literature to support habitat analyses for the Missouri River effects analysis. Draft. Vicksburg, MS: U.S. Army Engineer Research and Development Center.

Herb, W. R., and H. G. Stefan. 2011. Modified equilibrium temperature models for coldwater streams Water Resources Research. 47: Wo6519.

Hydrologic Engineering Center (HEC). 2016. HEC-RAS river analysis system user's manual version 5.o. Davis, CA: U.S. Army Corps of Engineers, Institute for Water Resources, Hydrologic Engineering Center.

Krider, L. A., J. A. Magner, J. Perry, B. Vondracek, and L. C. Ferrington. 2013. Air-water temperature relationships in the trout streams of southeastern Minnesota's carbonate-sandstone landscape. Journal of the American Water Resources Association 49(4): 896-907.

Langan, S. J., U. L. Johnston, M. J. Donaghy, A. F. Youngson, D. W. Hay, and C. Soulsby 2001. Variation in river water temperatures in an upland stream over a 30-year period, Science of the Total Environment 265(1-3): 195-207.

Leonard, B. P. 1991. The ULTIMATE conservative difference scheme applied to unsteady one-dimensional advection. Computer Methods in Applied Mechanics and Engineering 88(1): 17-74

Leonard, B. P. 1979. A stable and accurate convective modelling procedure based on upstream interpolation. Computer Methods in Applied Mechanics and Engineering 19(1): 59-98.

Mackey, A. P., and A. D. Berrie. 1991. The prediction of water temperature in chalk streams from air temperatures. Hydrobiologia 210(3): 183-189.

Mohseni, O., H. G. Stefan, and T. R. Erickson. 1998. A non-linear regression model for weekly stream temperatures. Water Resources Research 34(10): 2685-2692.

Morill, J. C., R. C. Bales, and M. H. Conklin. 2005. Estimating stream temperature from air temperature: Implications for future water quality. Journal of Environmental Engineering 131(1): 139-146. 
Nelson, K. C., and M. A. Palmer. 2007. Stream temperature surges under urbanization and climate change: Data, models, and responses, Journal of the American Water Resources Association 43(2): 440-452.

Pilgrim, J. M., X. Fang, and H. G. Stefan. 1998. Stream temperature correlations with air temperatures in Minnesota: Implications for climate warming. Journal of the American Water Resources Association 34(5): 1109-1121.

Rabi, A., M. Hadzima-Nyarko, and M. Sperac. 2015. Modelling river temperature from air temperature in the River Drava (Croatia). Hydrological Sciences Journal 6o(9): 1490-1507.

Saffran, K. A., and A-M. Anderson. 1997. An empirical analysis of water temperature and dissolved oxygen conditions in the Red Deer river. Edmonton, Alberta, Canada: Alberta Environmental Protection, Environmental Monitoring and Evaluation Branch. http://www3.gov.ab.ca/env/info/infocentre/publist.cfm.

Smith, K. 1981. The prediction of river water temperature. Hydrological Science Bulletin 26(1): 19-32.

Stefan, H. G., and E .B. Preud'homme. 1993. Stream temperature estimation from air temperature. Journal of the American Water Resources Association 29(1): 2745 .

U.S. Army Corps of Engineers (USACE). 2014a. Missouri River ResSim input data development, Missouri River basin time series data set development report. Omaha, NE: U.S. Army Corps of Engineers, Omaha District.

U.S. Army Corps of Engineers (USACE). 2014b. Missouri River recovery program, quality management plan. Kansas City, MO: U.S. Army Corps of Engineers, Kansas City District.

U.S. Army Corps of Engineers (USACE). 2015. Missouri River recovery program management plan environmental impact statement existing conditions unsteady HEC-RAS model calibration report. Omaha, NE/Kansas City, MO: U.S. Army Corps of Engineers, Northwestern Division, and Kansas City District.

U.S. Army Corps of Engineers (USACE). 2016. Daft Missouri River recovery management plan and environmental impact statement. Omaha, NE/Kansas City, MO: U.S. Army Corps of Engineers, Northwestern Division, and Kansas City District.

Van Vliet, M. T. H, J. R. Yearsley, W. H. P. Franssen, F. Ludwig, I. Haddeland, D. P. Lettenmaier, and P. Kabat. 2012. Coupled daily streamflow and water temperature modelling in large river basins. Hydrology and Earth System Sciences 16(11): 4303-4321.

Webb, B.W., P. D. Clack, and D. E. Walling. 2003. Water-air temperature relationships in a Devon river system and the role of flow. Hydrological Processes 17(15): 3069-3084.

Webb, B. W., and F. Nobilis. 1997. Long-term perspective on the nature of the air-water temperature relationship: A case study. Hydrological processes 11(2): 137-147. 
Zhang, Z., and B. E. Johnson. 2016. Aquatic nutrient simulation modules (NSMs) developed for hydrologic and hydraulic models. ERDC/EL TR-16-1. Vicksburg, MS: U.S. Army Engineer Research and Development Center. 


\section{Appendix A: Time Series Plots of Regression Computed versus Observed Water Temperatures for the Garrison Dam to Oahe Dam River Reach}

Figures A1-A8 show the 18 year (1995-2012) time series plots of regression computed and observed inflow boundary water temperatures for the Garrison Dam to Oahe Dam reach HEC-RAS model.

Figure A1. Regression computed versus observed water temperatures at BC1.

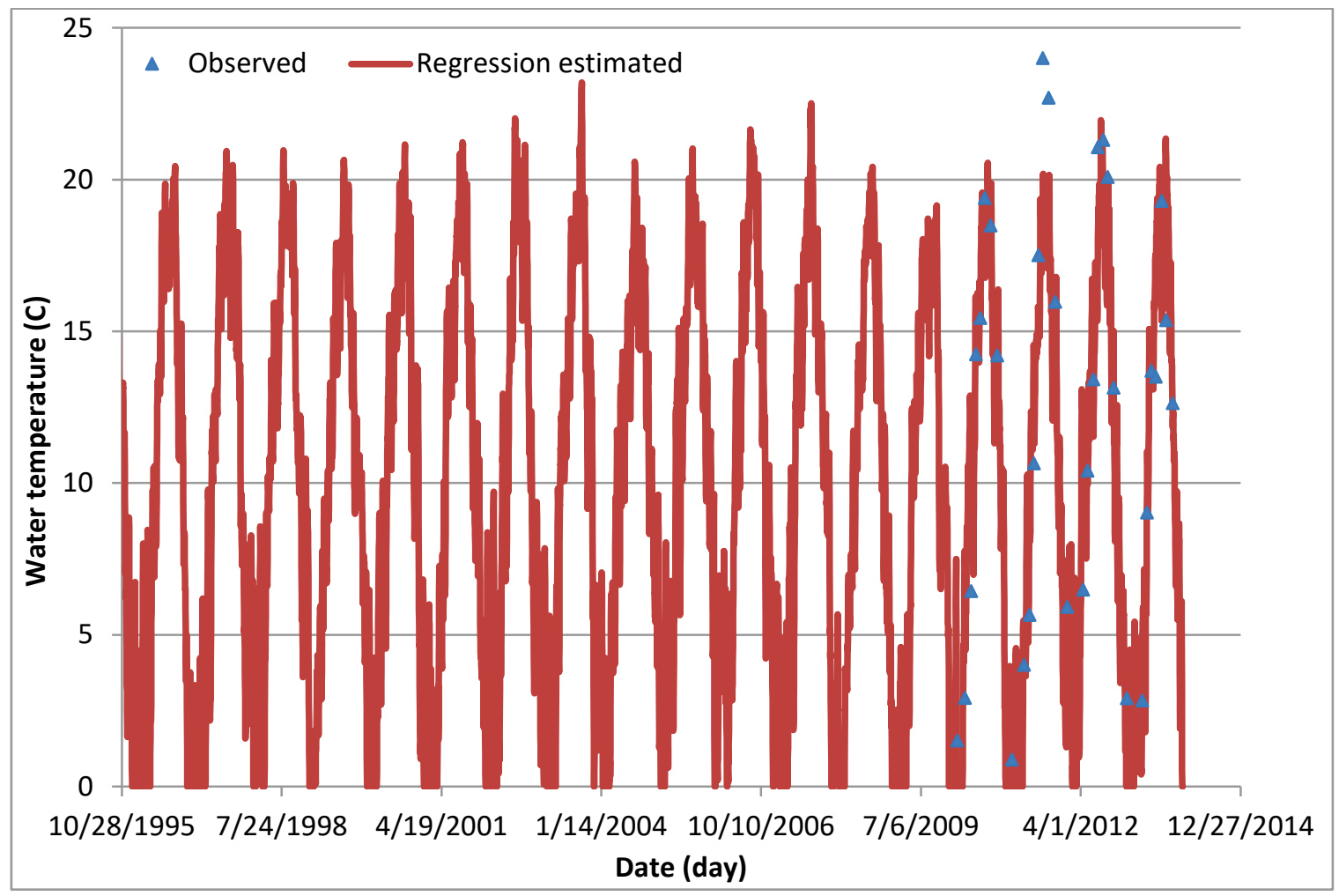


Figure A2. Regression computed versus observed water temperatures at BC2.

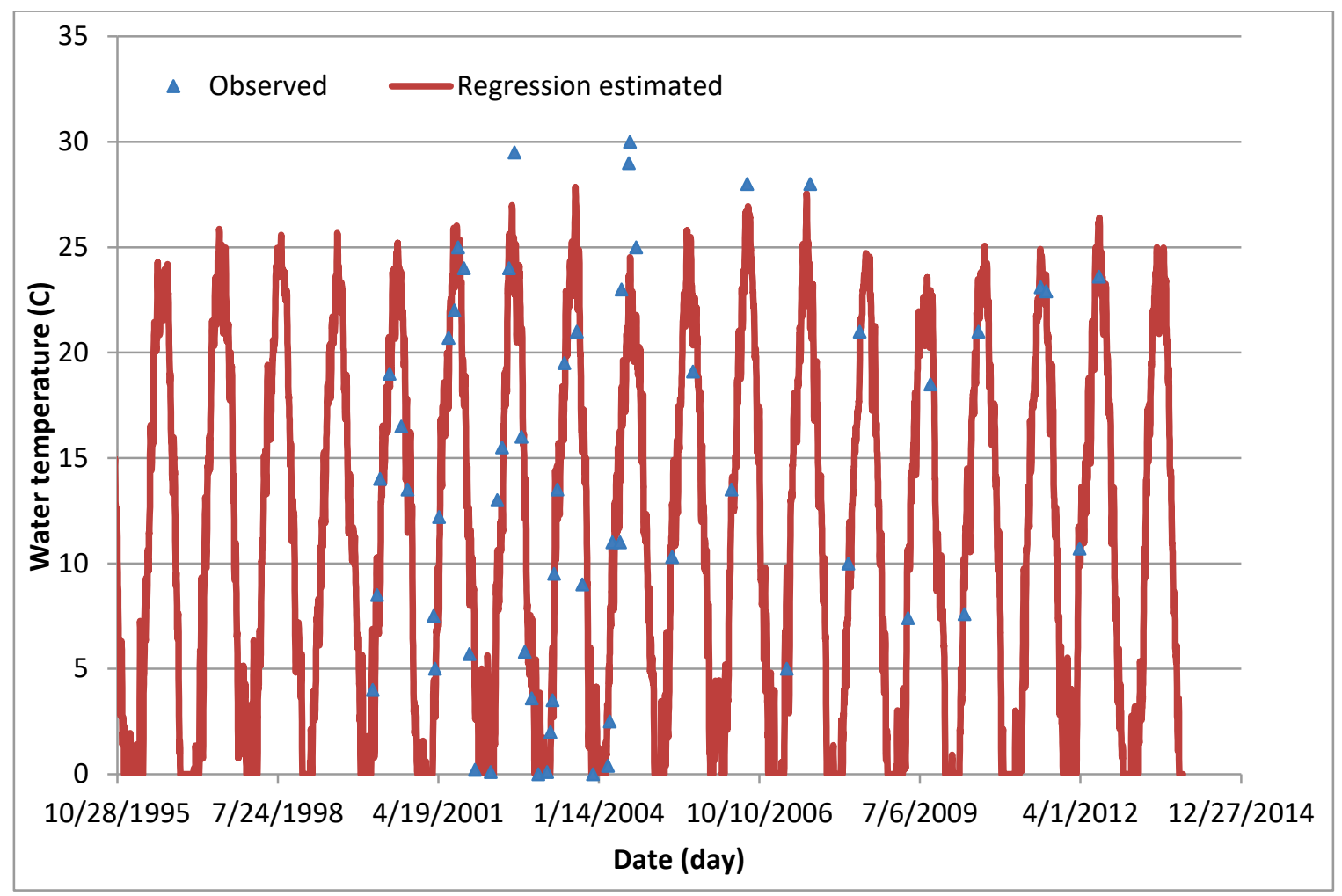

Figure A3. Regression computed versus observed water temperatures at BC3.

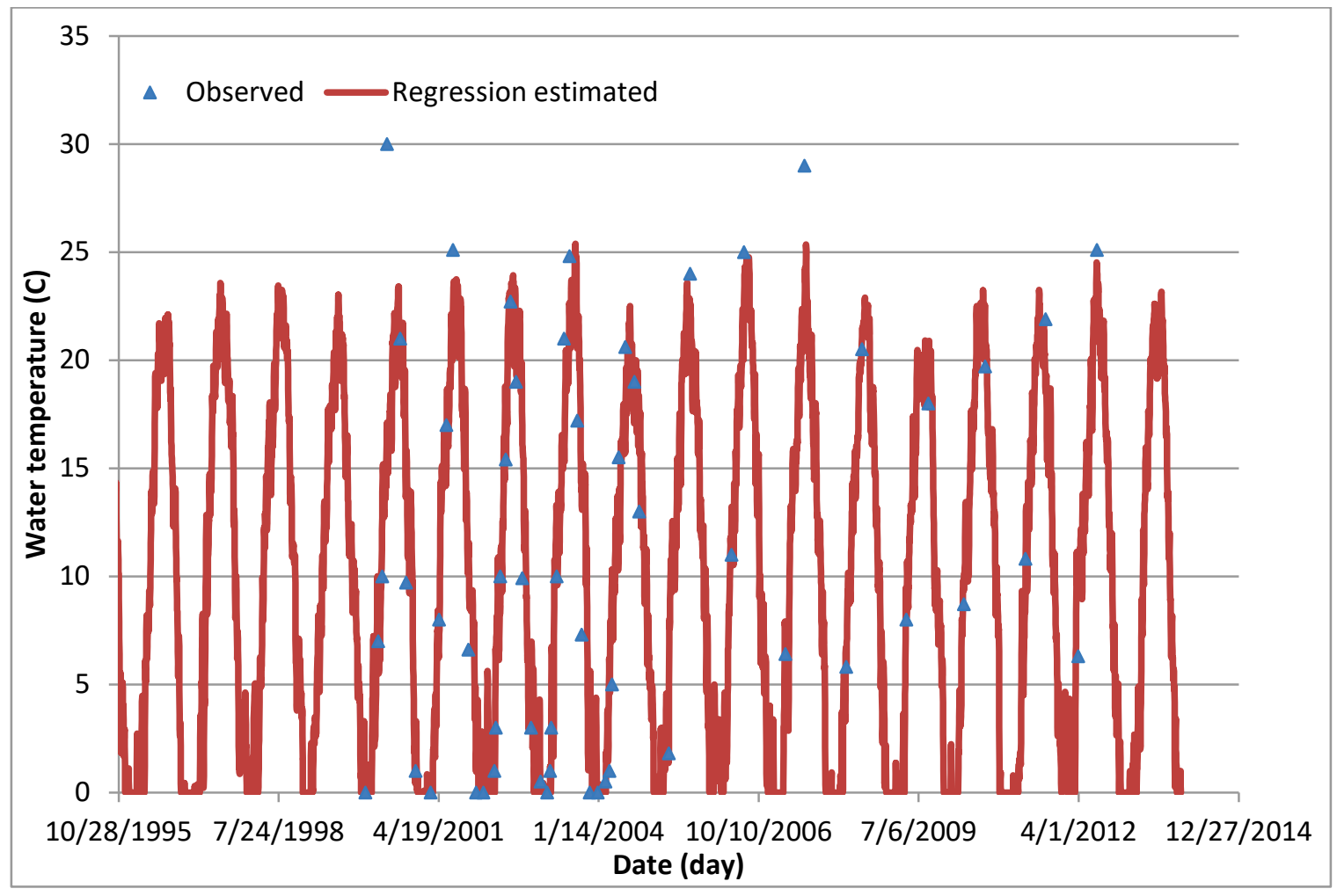


Figure A4. Regression computed versus observed water temperatures at BC4.

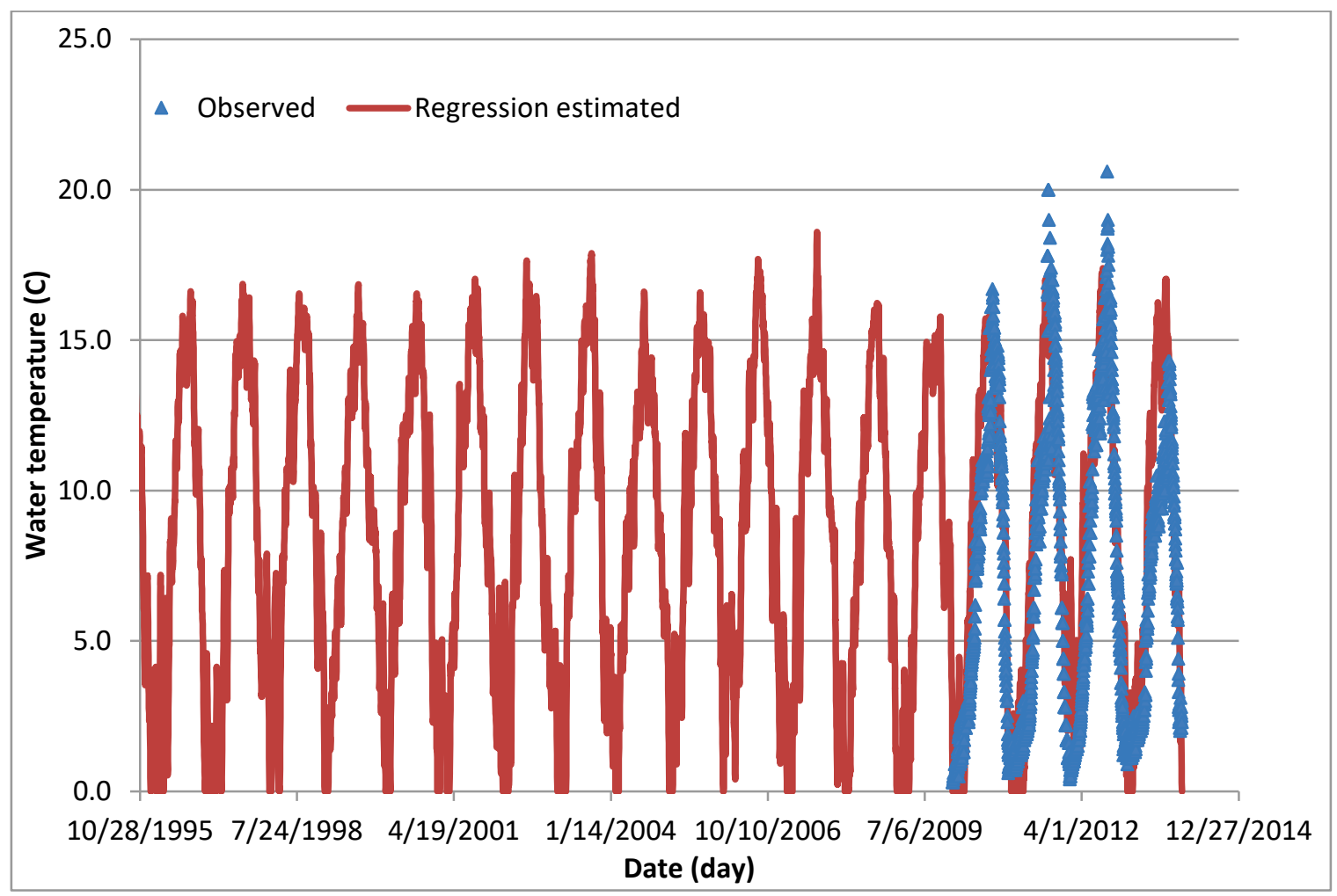

Figure A5. Regression computed versus observed water temperatures at BC5.

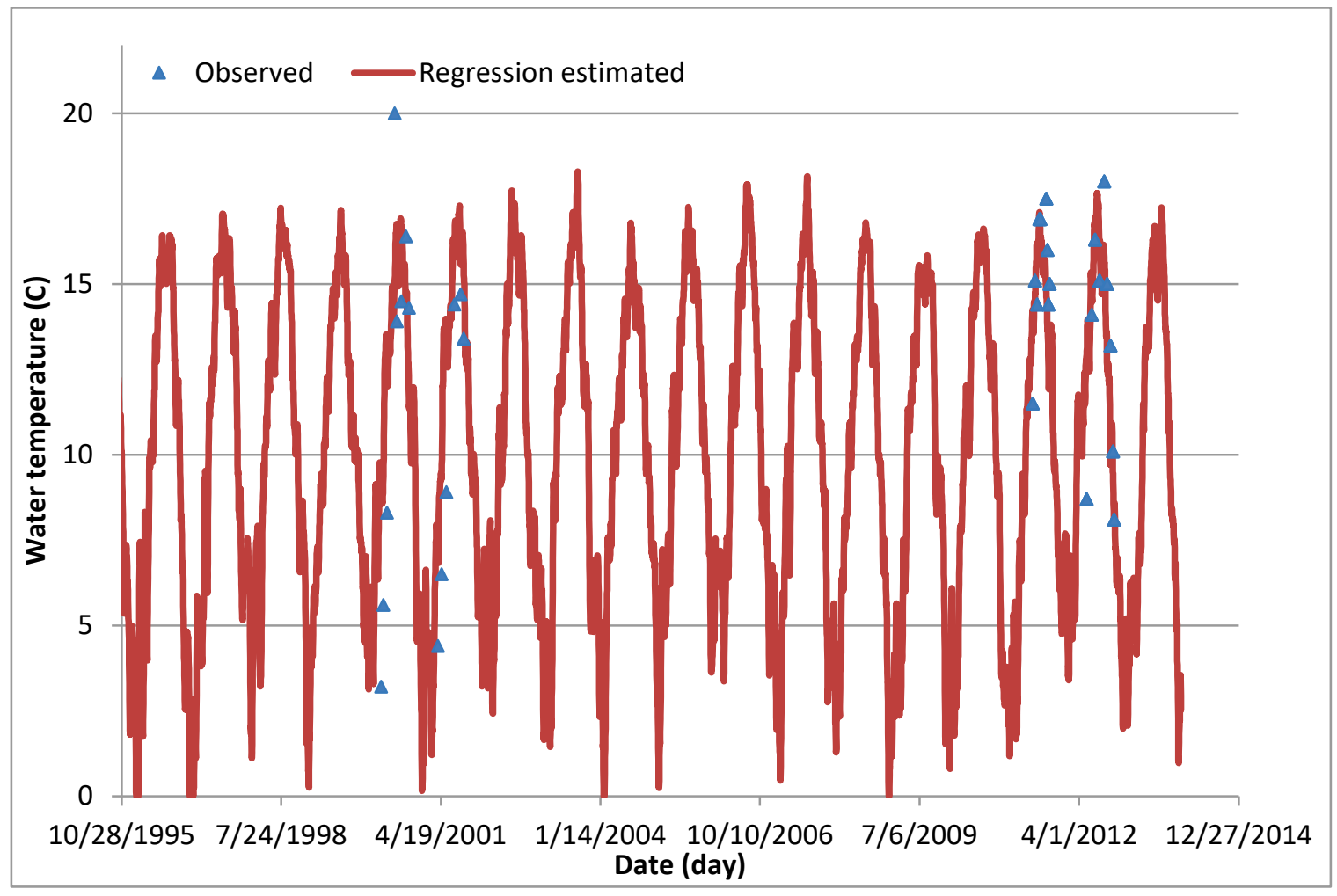


Figure A6. Regression computed versus observed water temperatures at BC6.

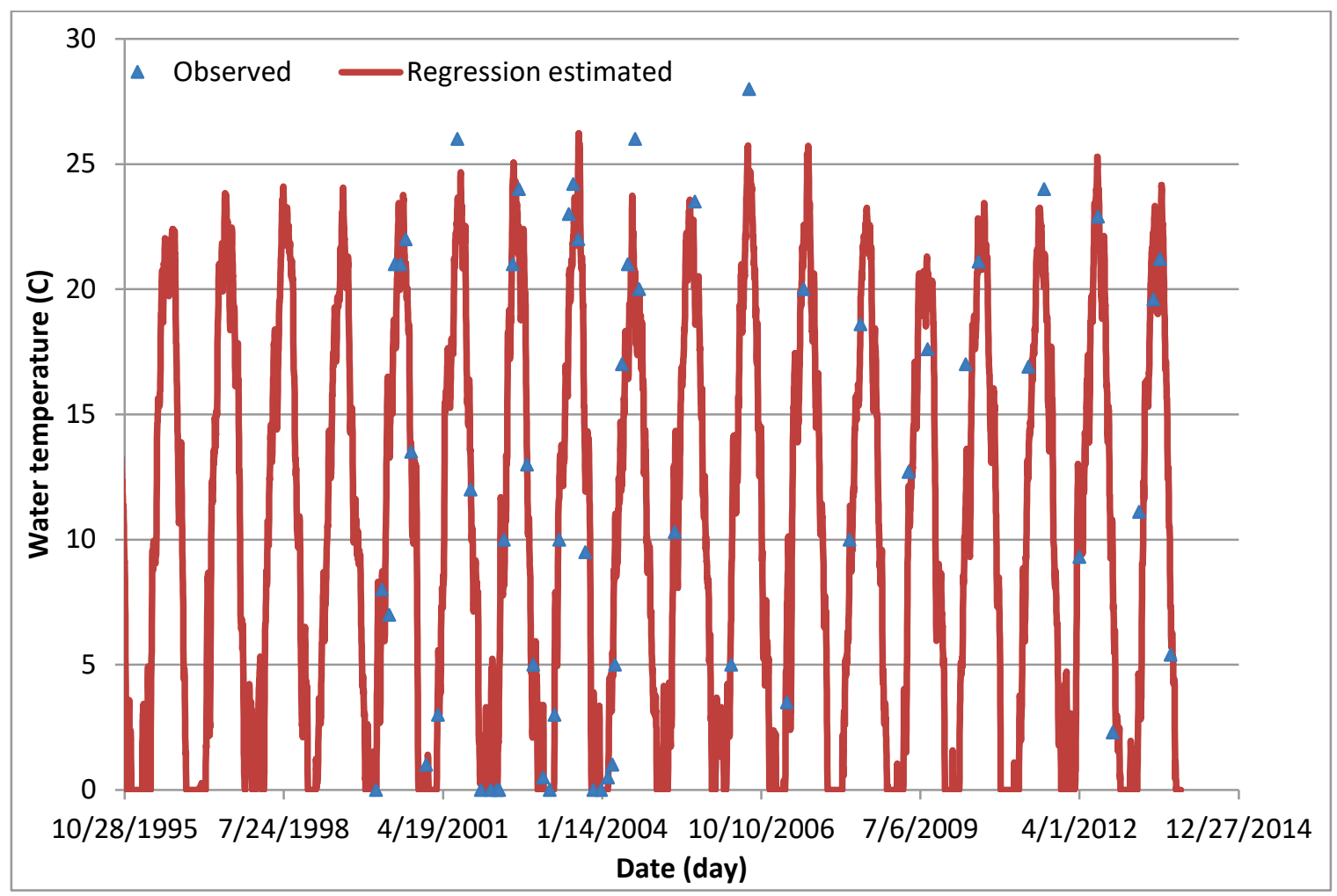

Figure A7. Regression computed versus observed water temperatures at BC7.

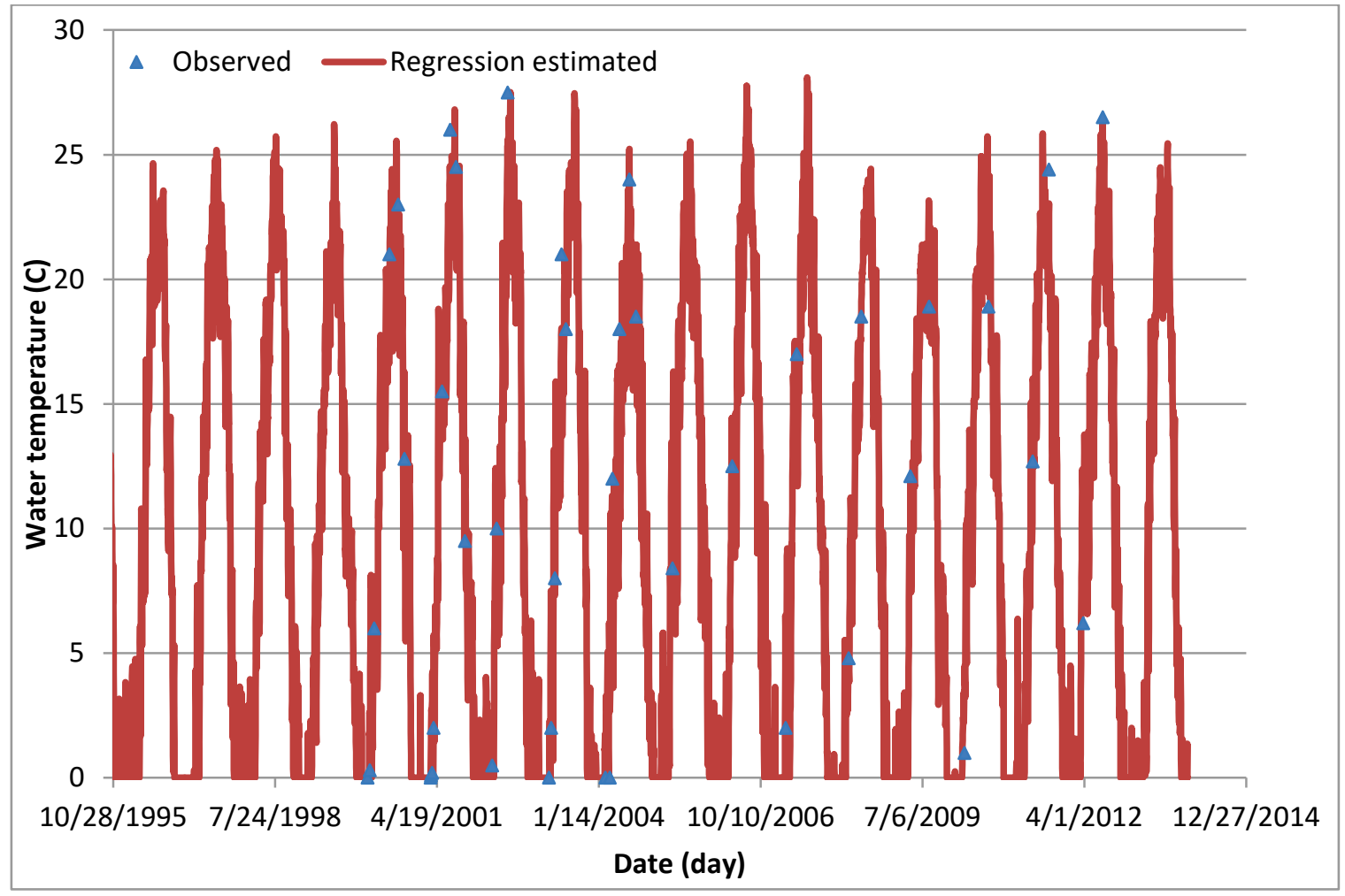


Figure A8. Regression computed versus observed water temperatures at BC8.

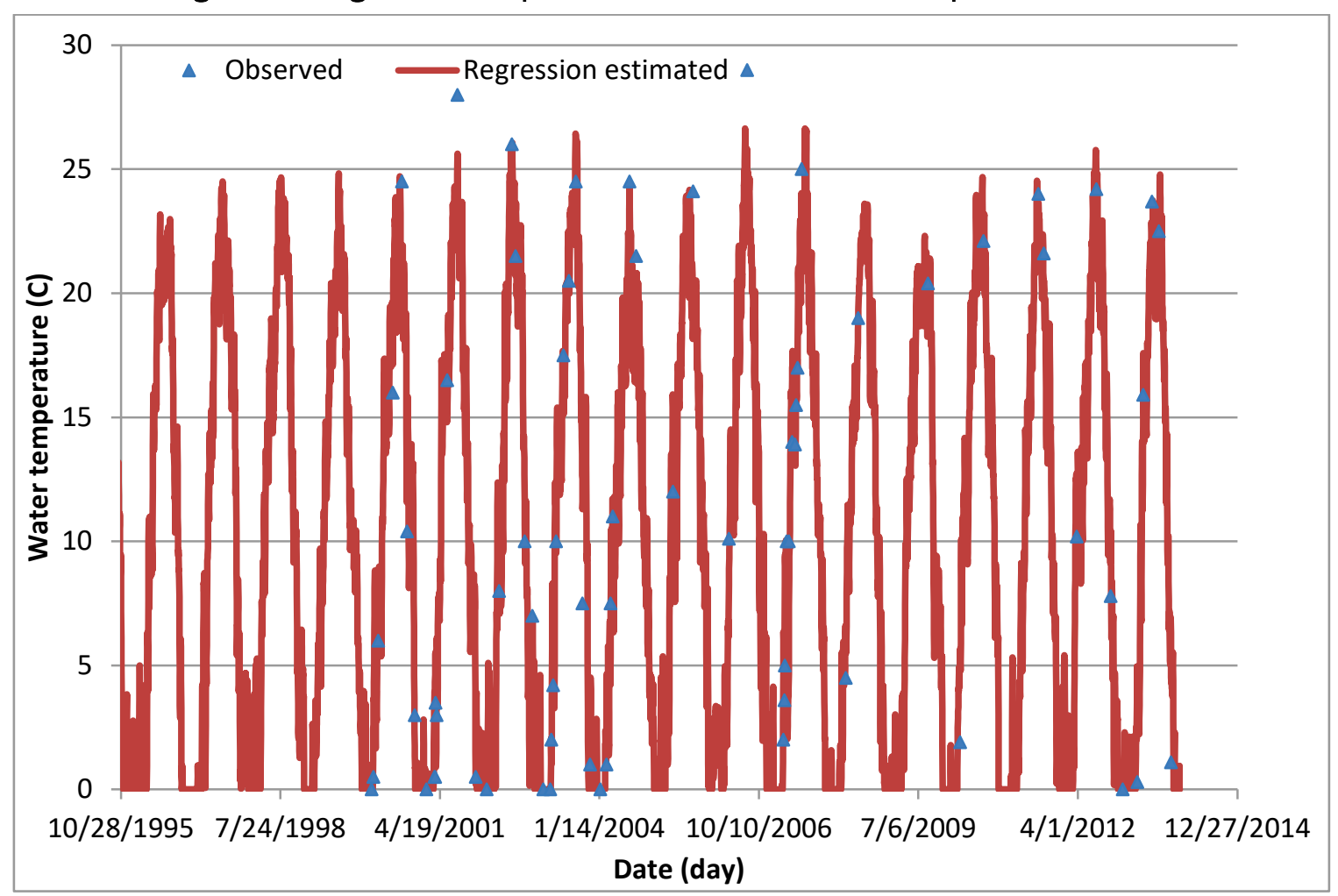




\section{Appendix B: Time Series Plots of Regression Computed versus Observed Water Temperatures for the Gavins Point Dam to Rulo River Reach}

Figures B1-B16 show the 18 year (1995-2012) time series plots of regression computed and observed inflow boundary water temperatures for the Gavins Point Dam to Rulo reach HEC-RAS model.

Figure B1. Regression computed versus observed water temperatures at BC1.

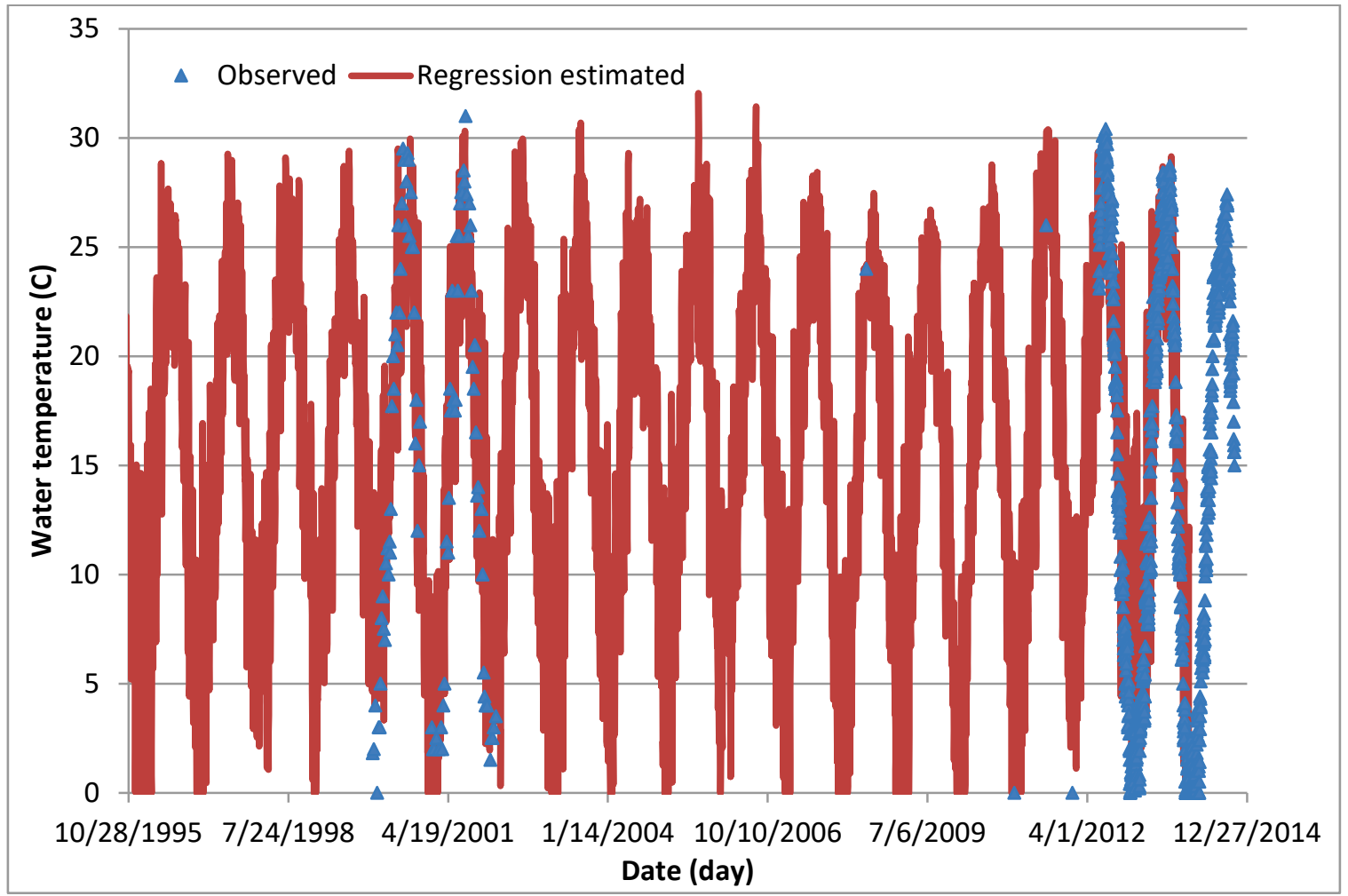


Figure B2. Regression computed versus observed water temperatures at BC2.

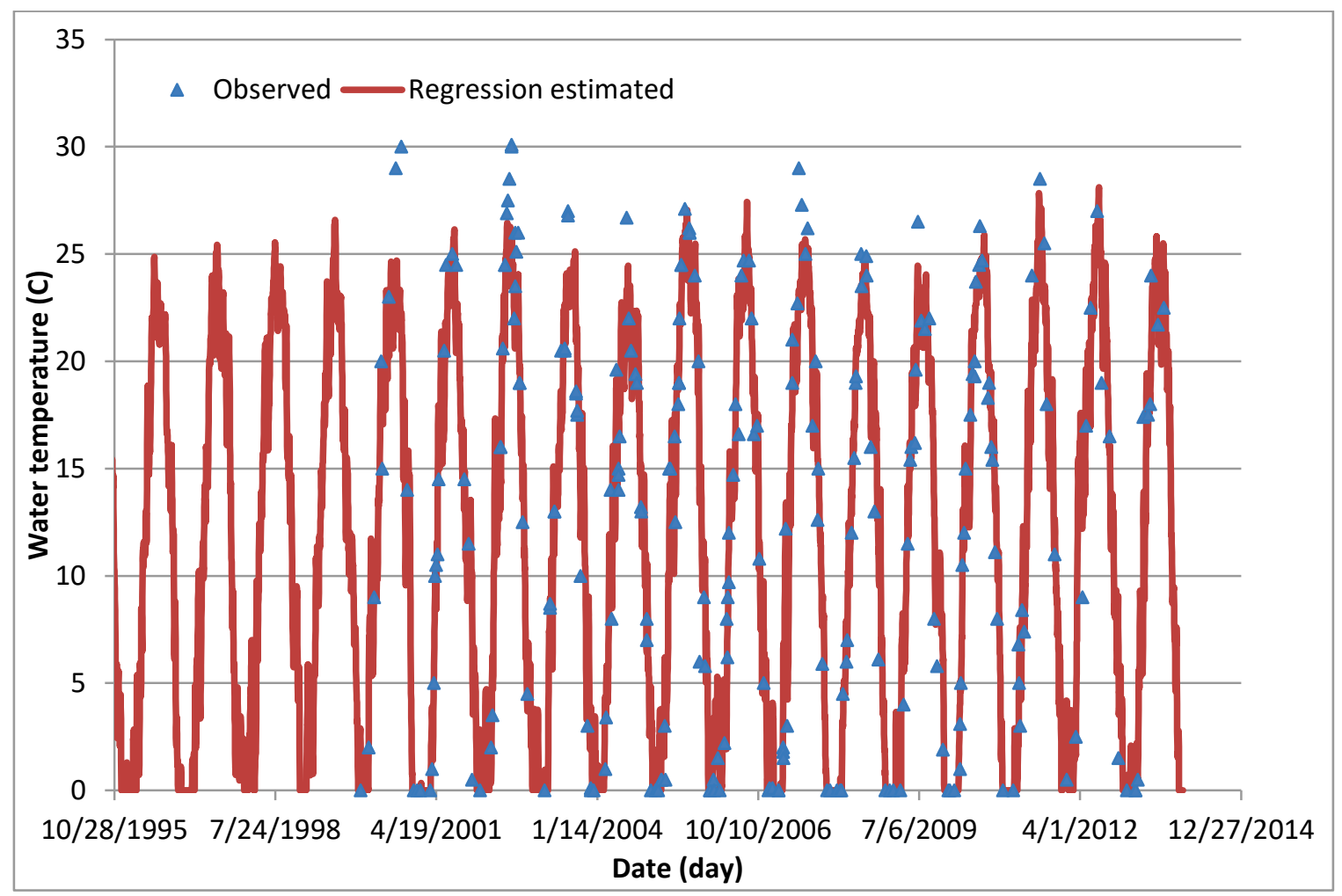

Figure B3. Regression computed versus observed water temperatures at BC3.

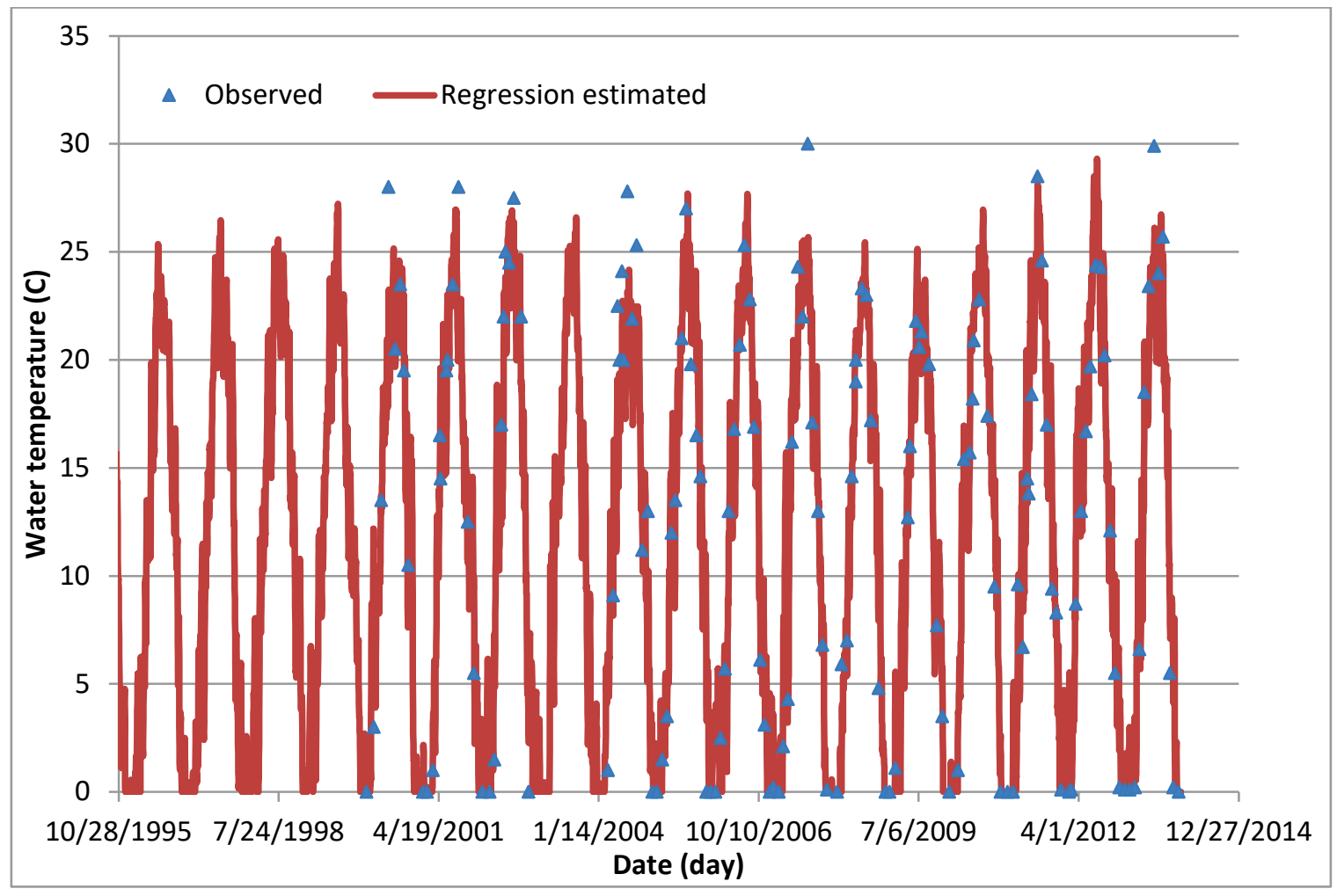


Figure B4. Regression computed versus observed water temperatures at BC4.

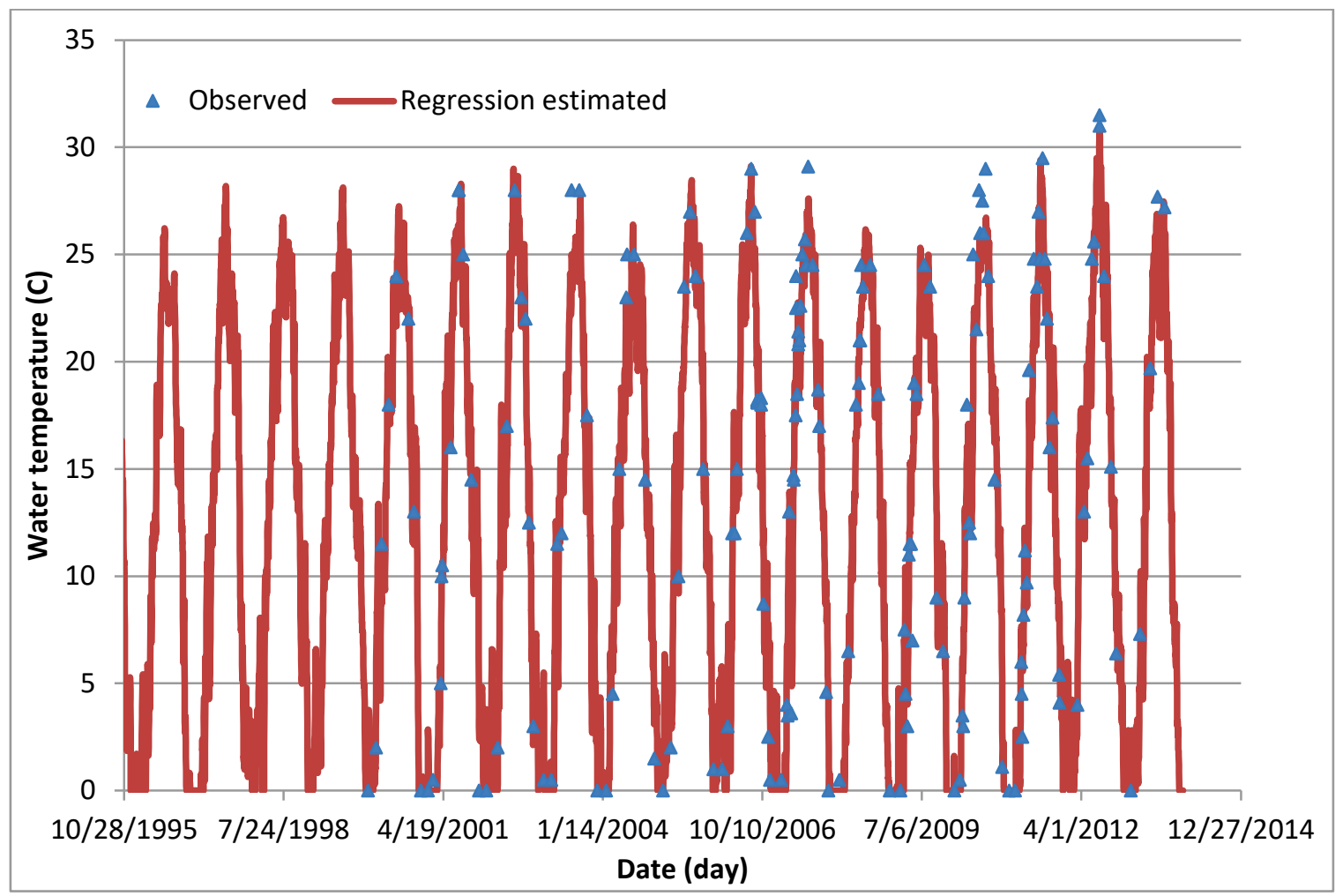

Figure B5. Regression computed versus observed water temperatures at BC5.

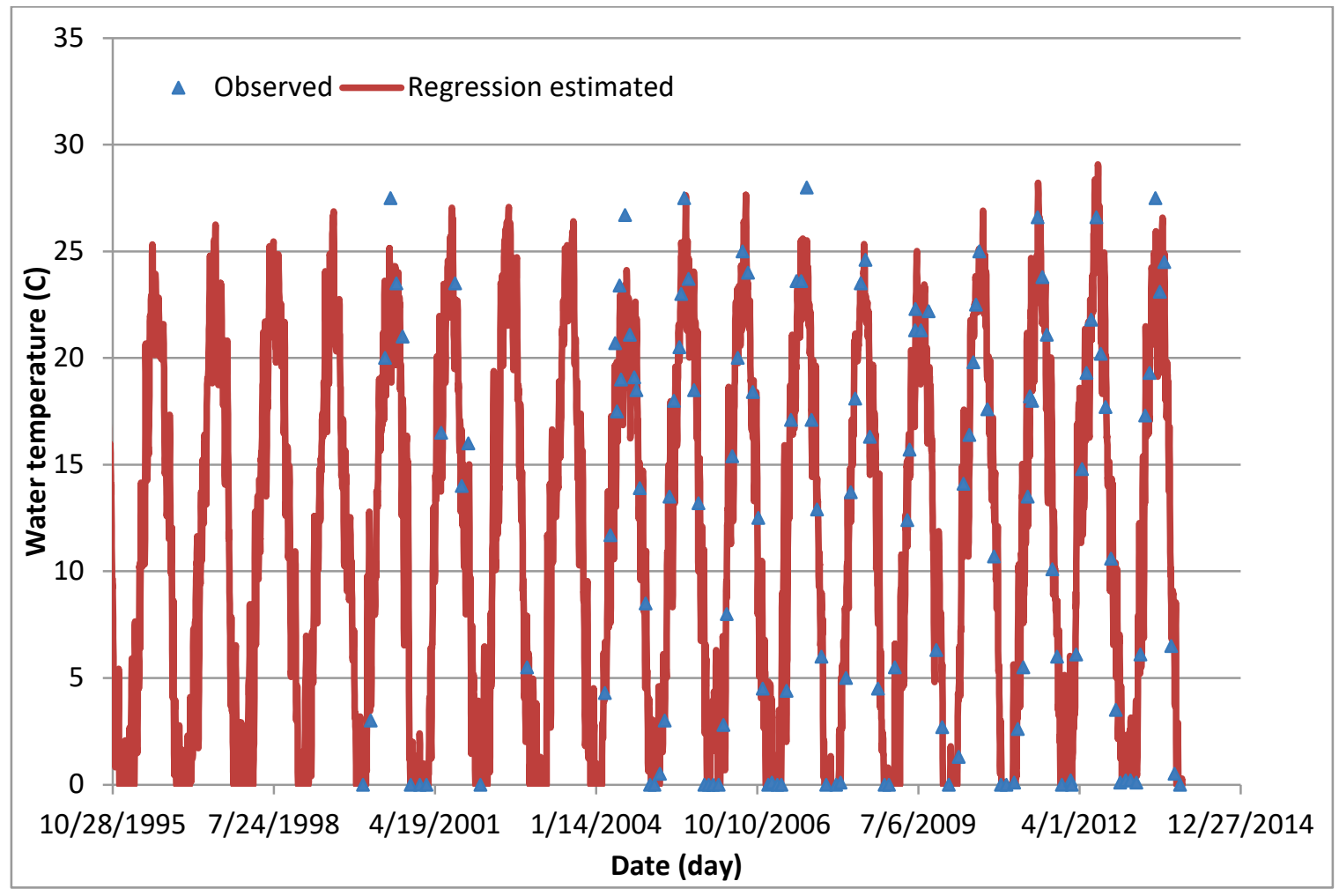


Figure B6. Regression computed versus observed water temperatures at BC6.

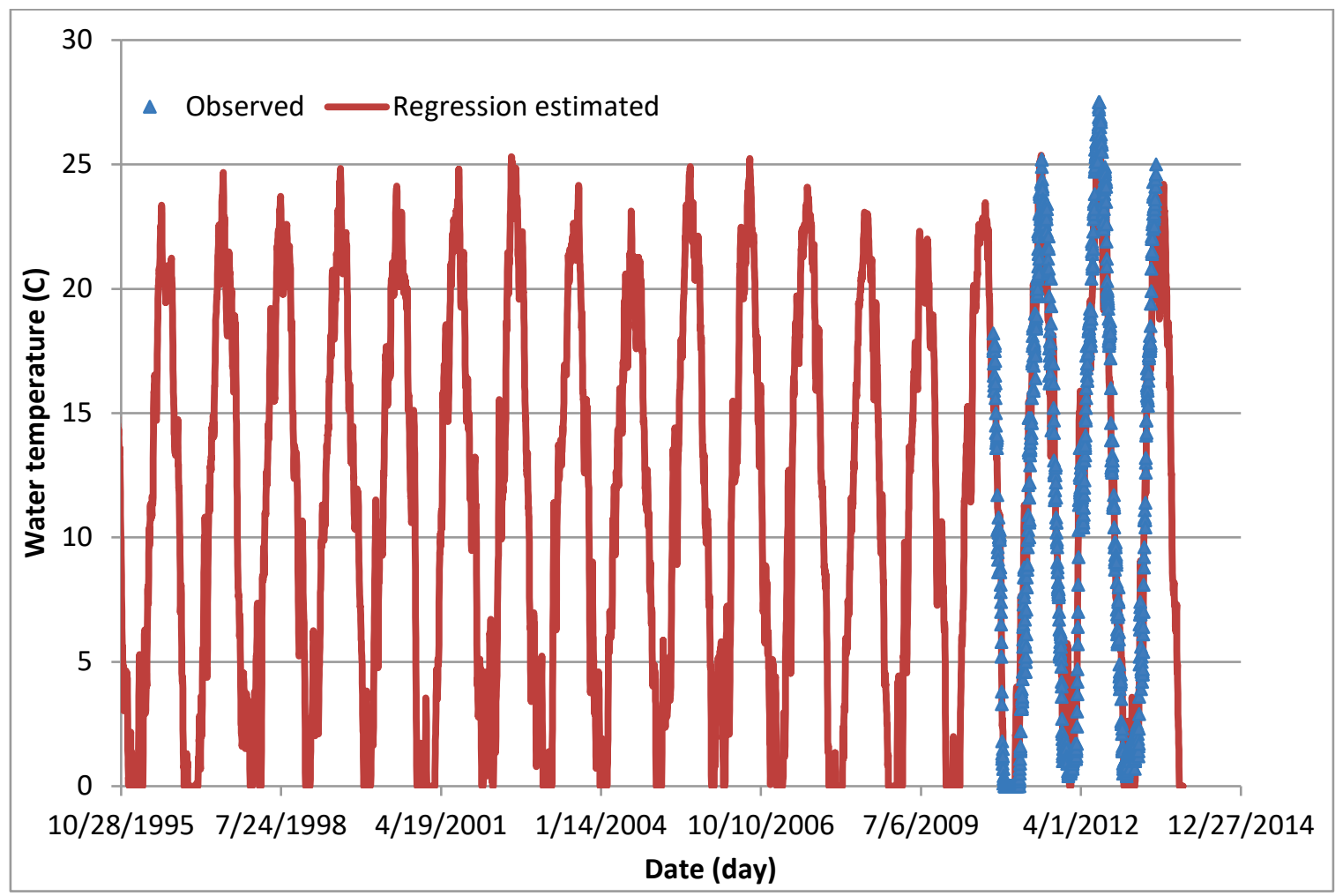

Figure B7. Regression computed versus observed water temperatures at BC7.

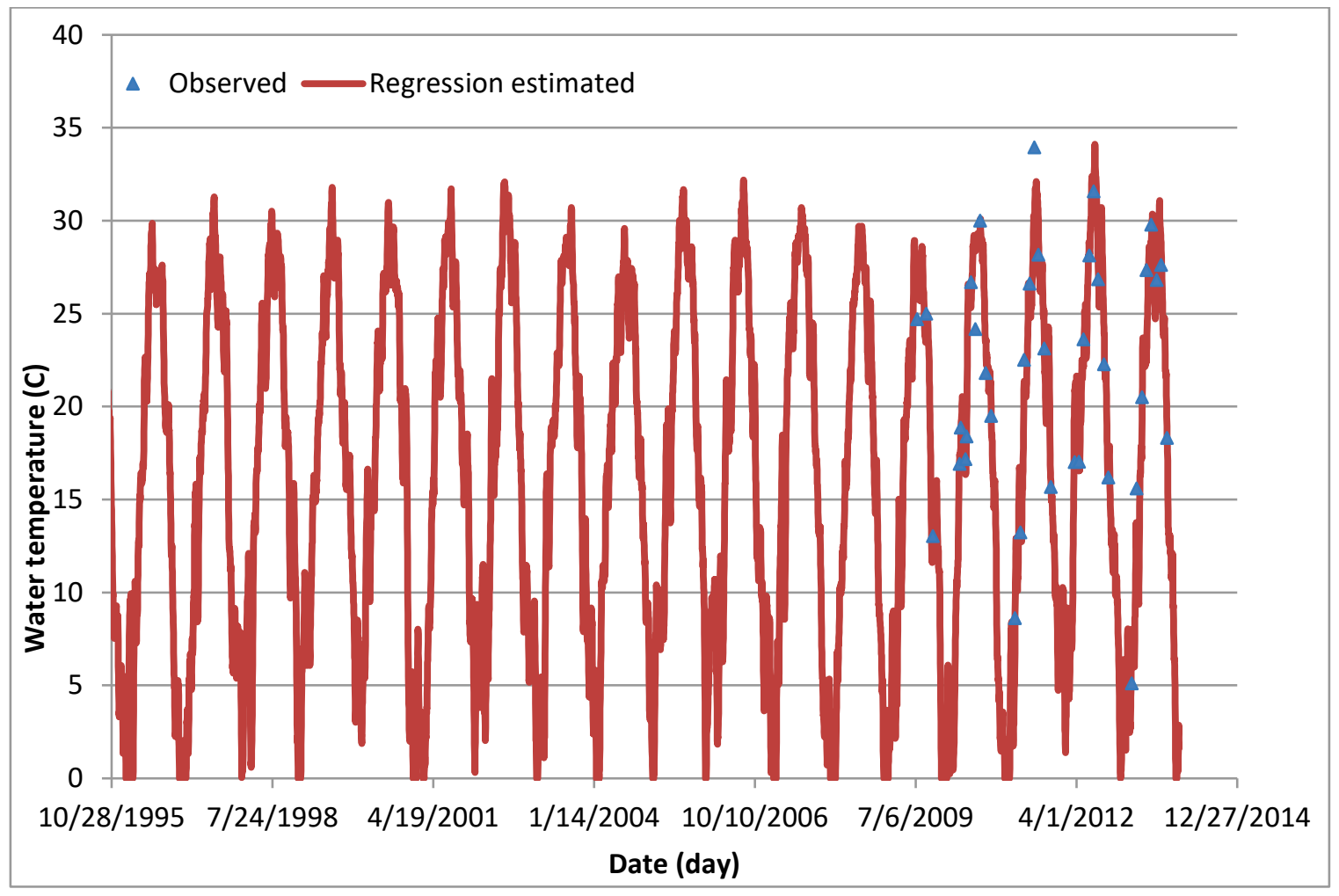


Figure B8. Regression computed versus observed water temperatures at BC8.

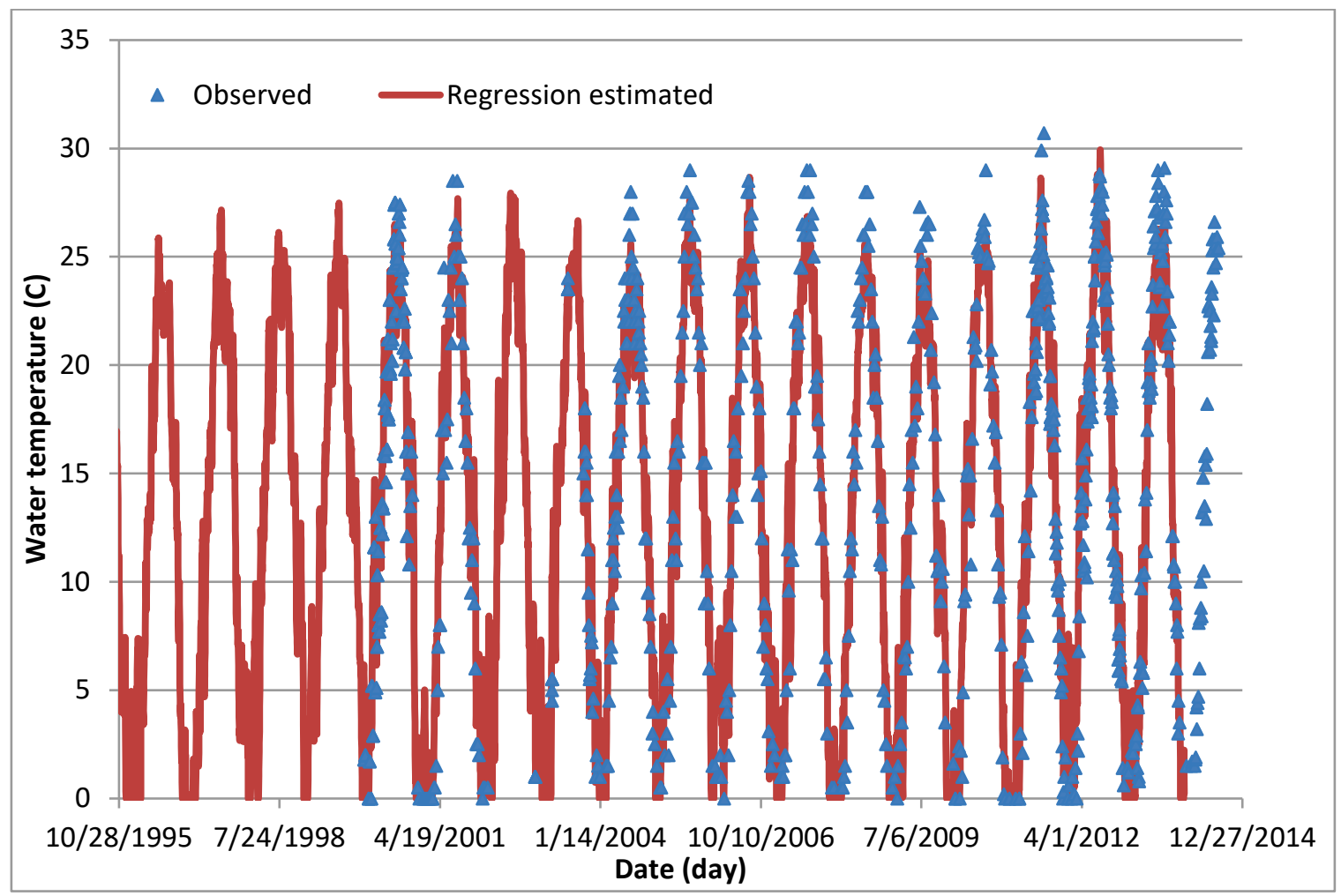

Figure B9. Regression computed versus observed water temperatures at BC9.

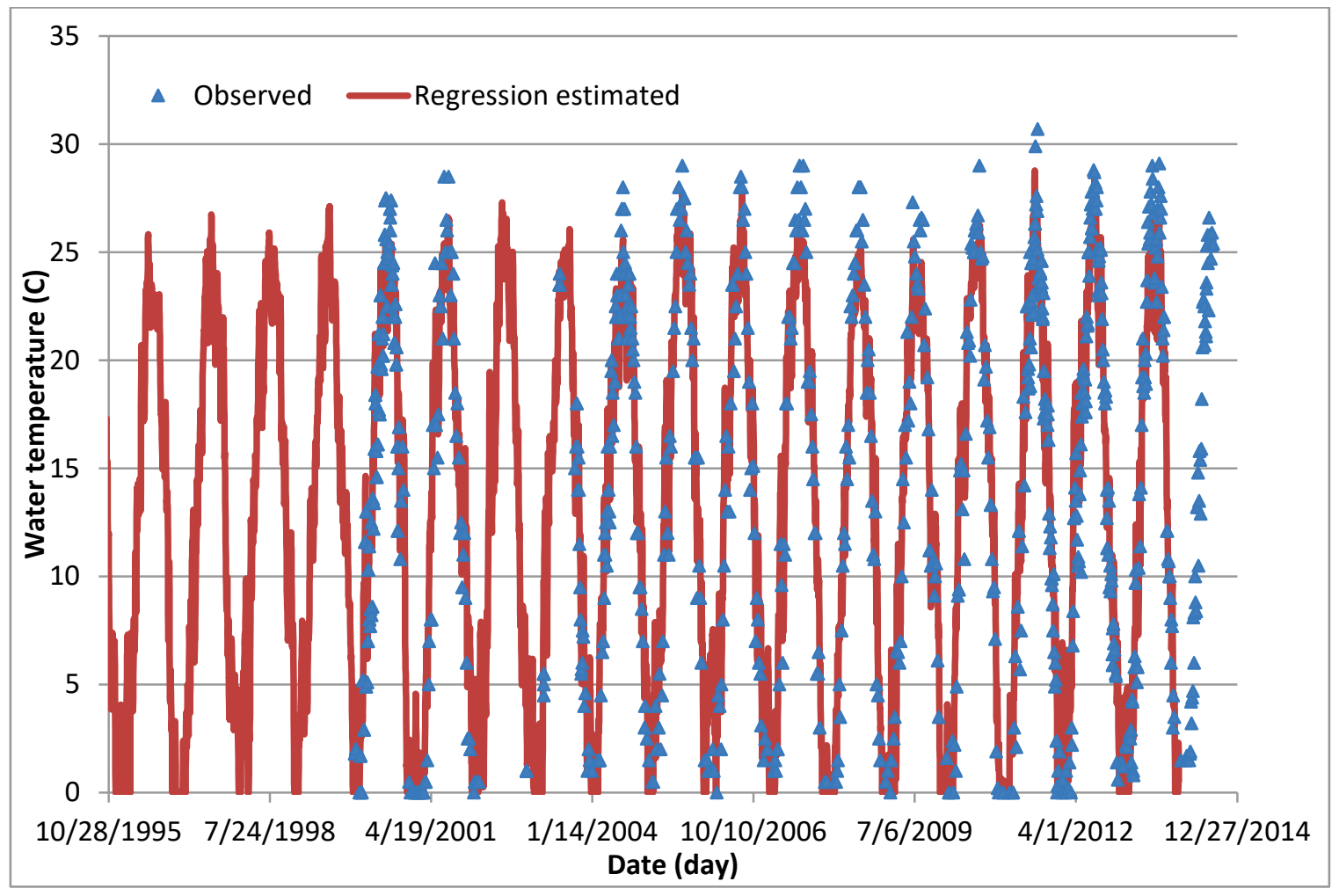


Figure B10. Regression computed versus observed water temperatures at BC10.

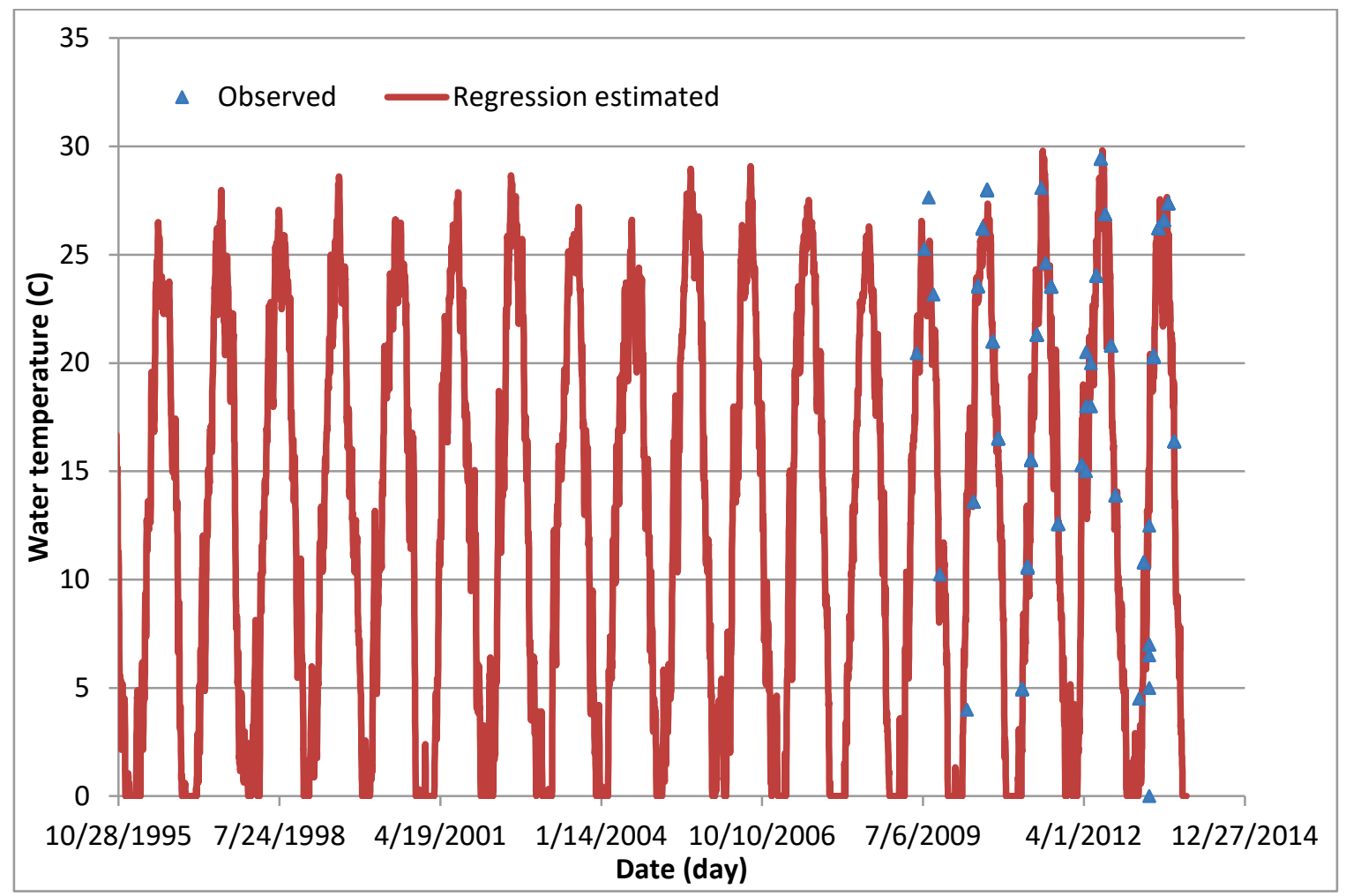

Figure B11. Regression computed versus observed water temperatures at BC11.

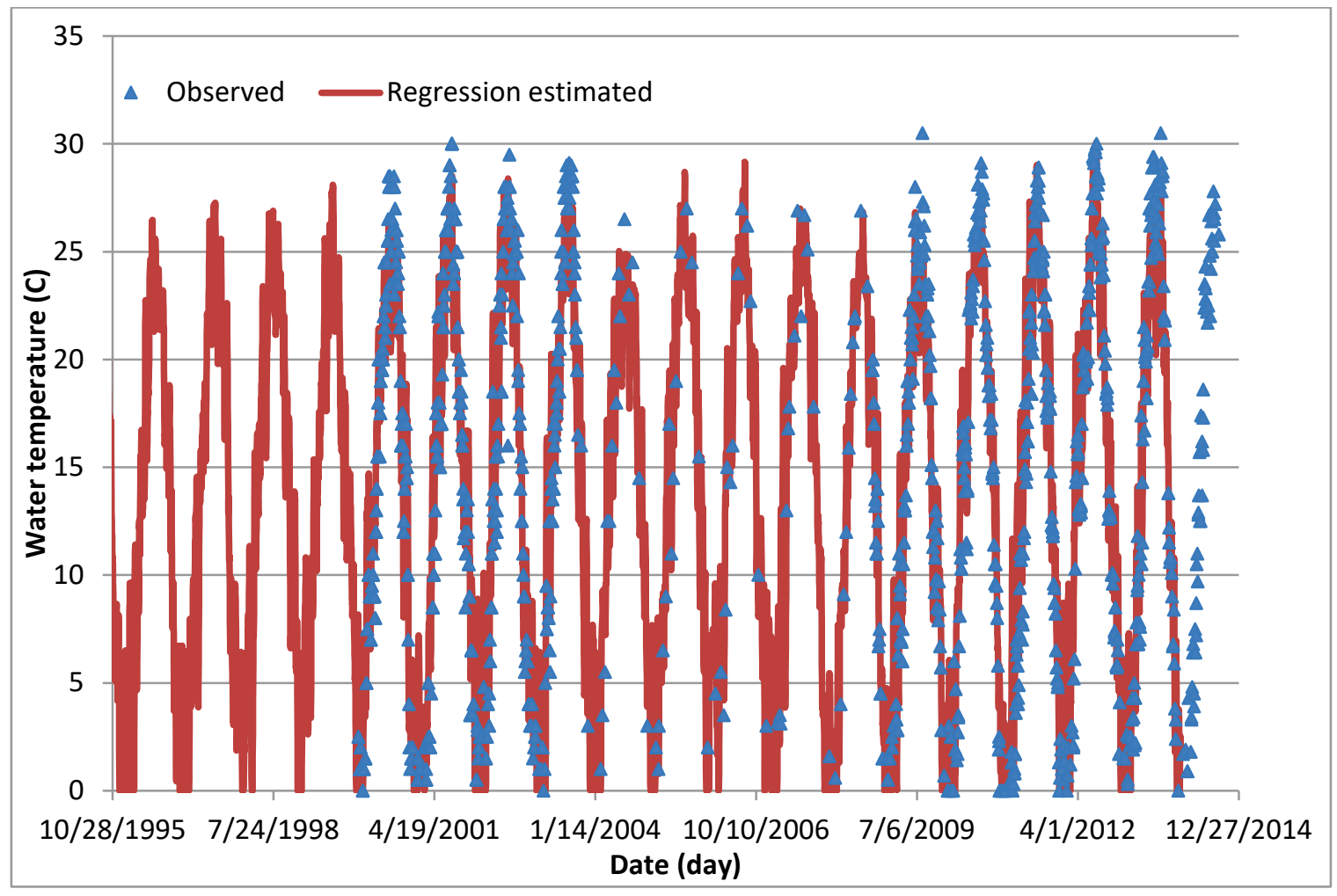


Figure B12. Regression computed versus observed water temperatures at BC12.

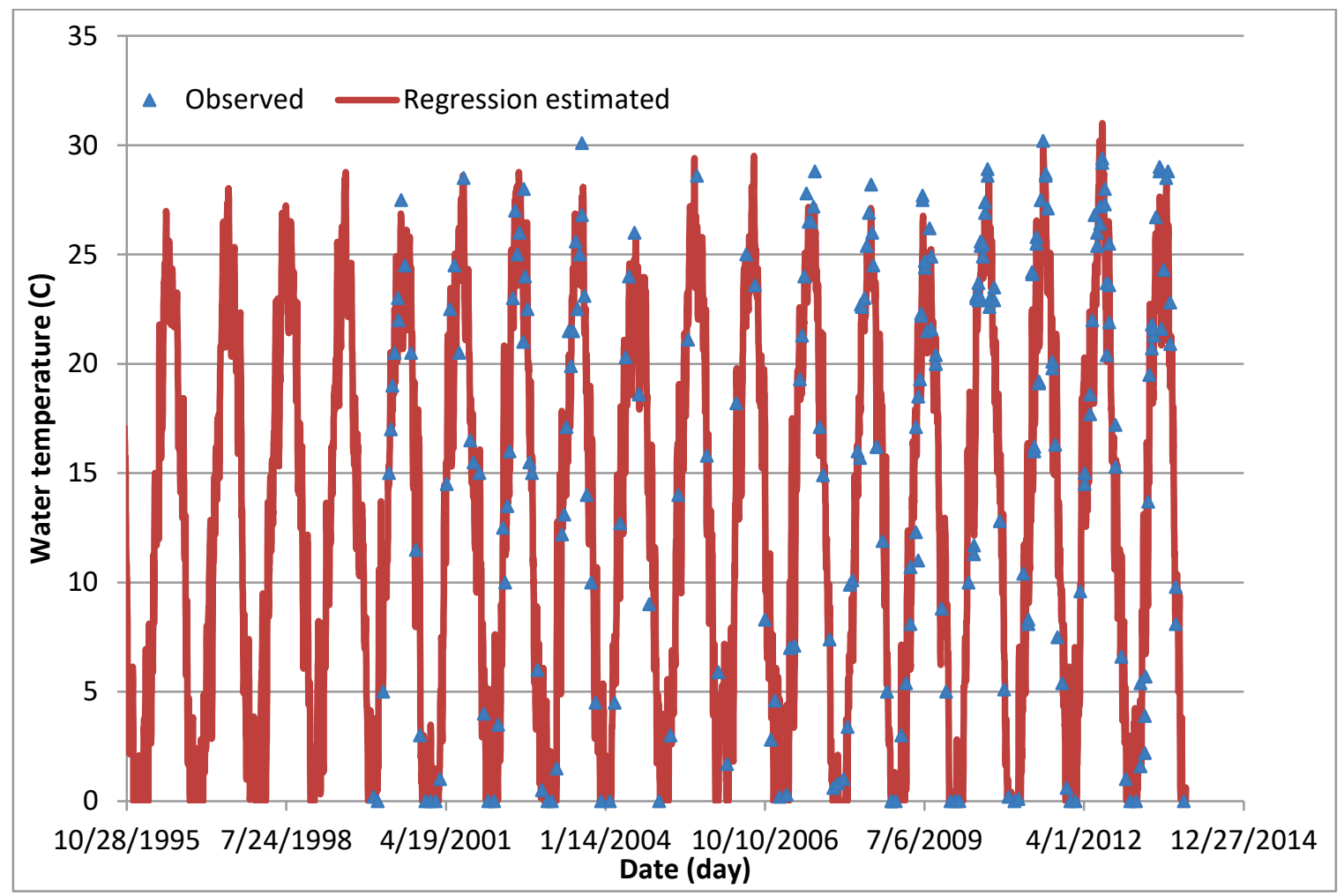

Figure B13. Regression computed versus observed water temperatures at BC13.

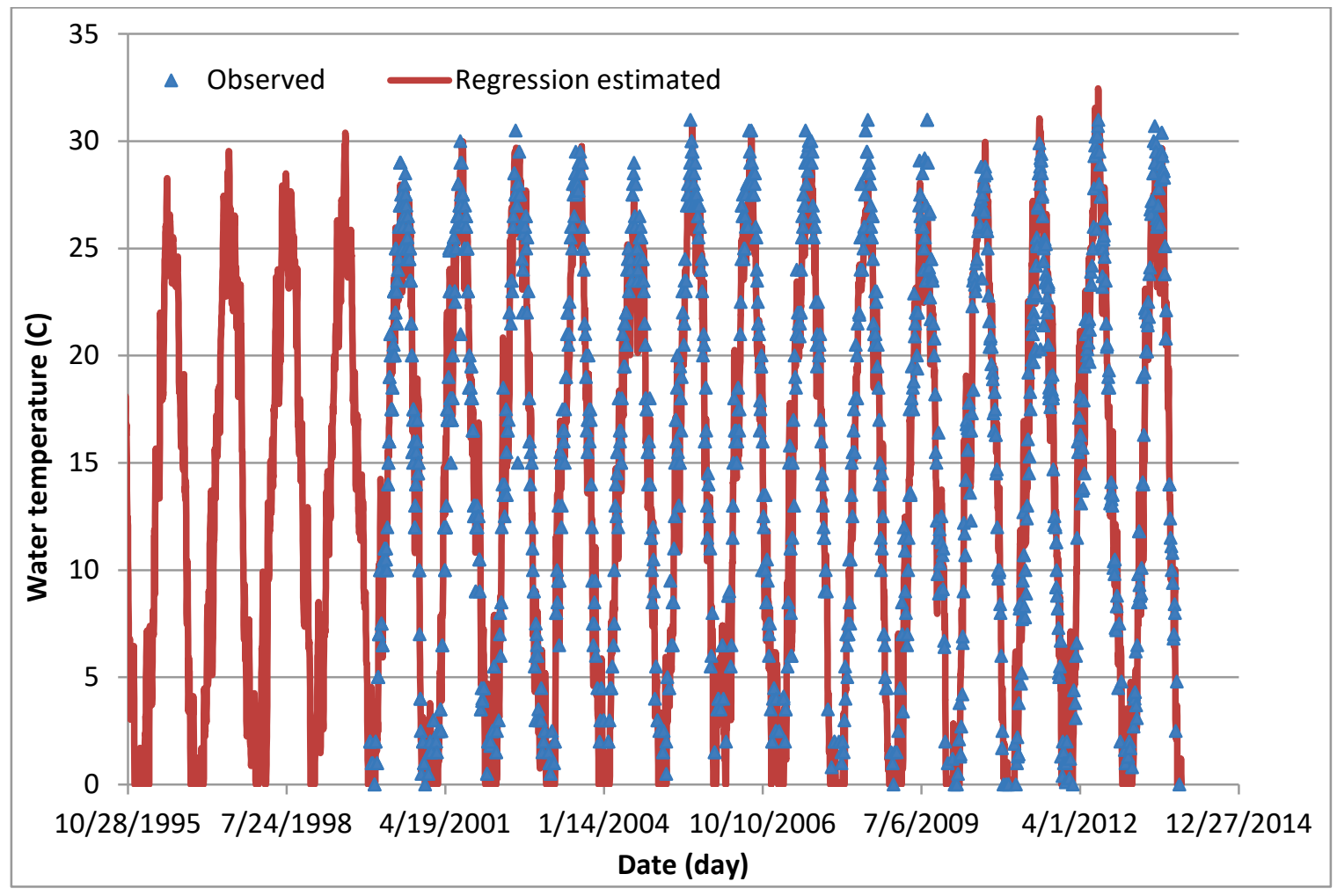


Figure B14. Regression computed versus observed water temperatures at BC14.

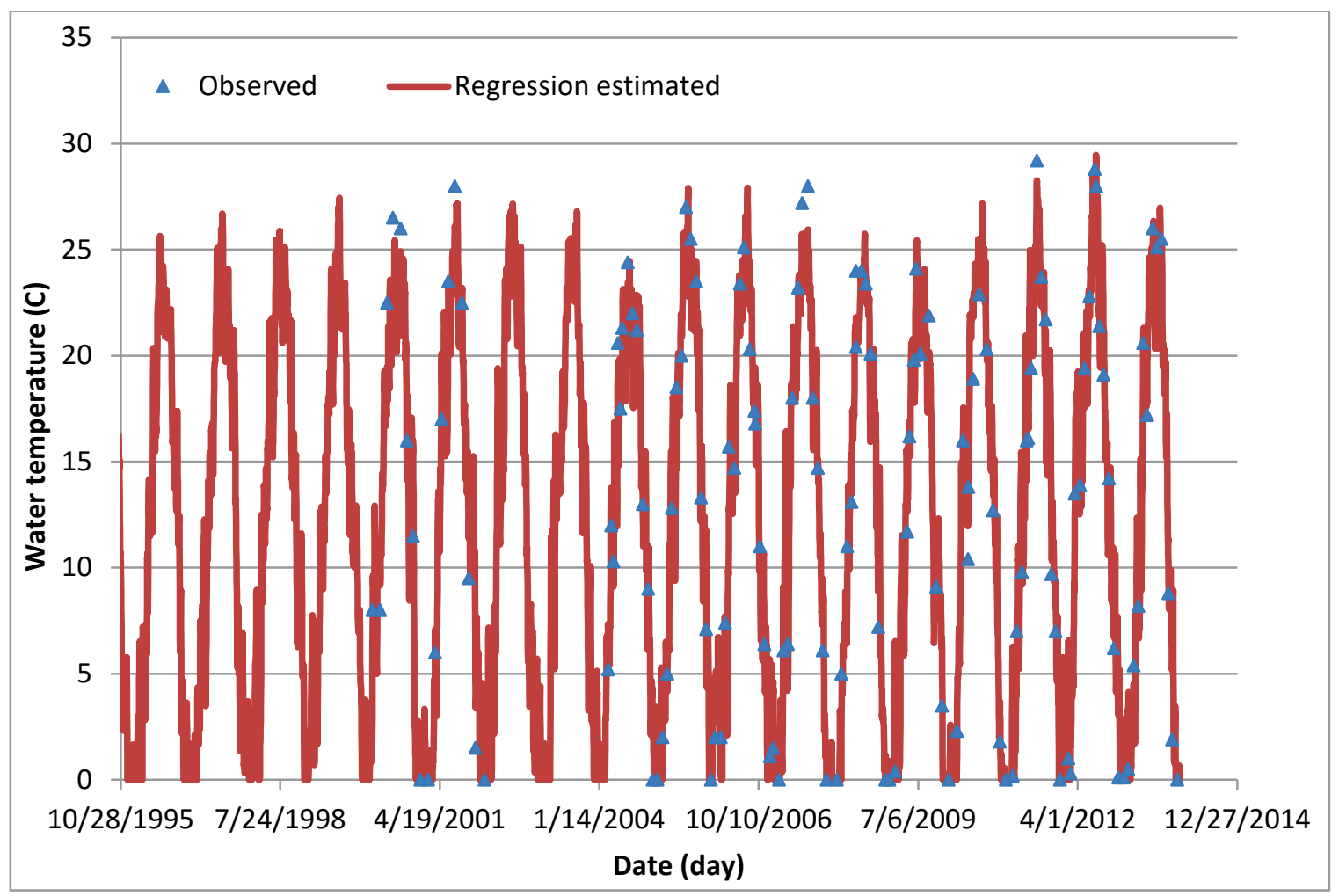

Figure B15. Regression computed versus observed water temperatures at BC15.

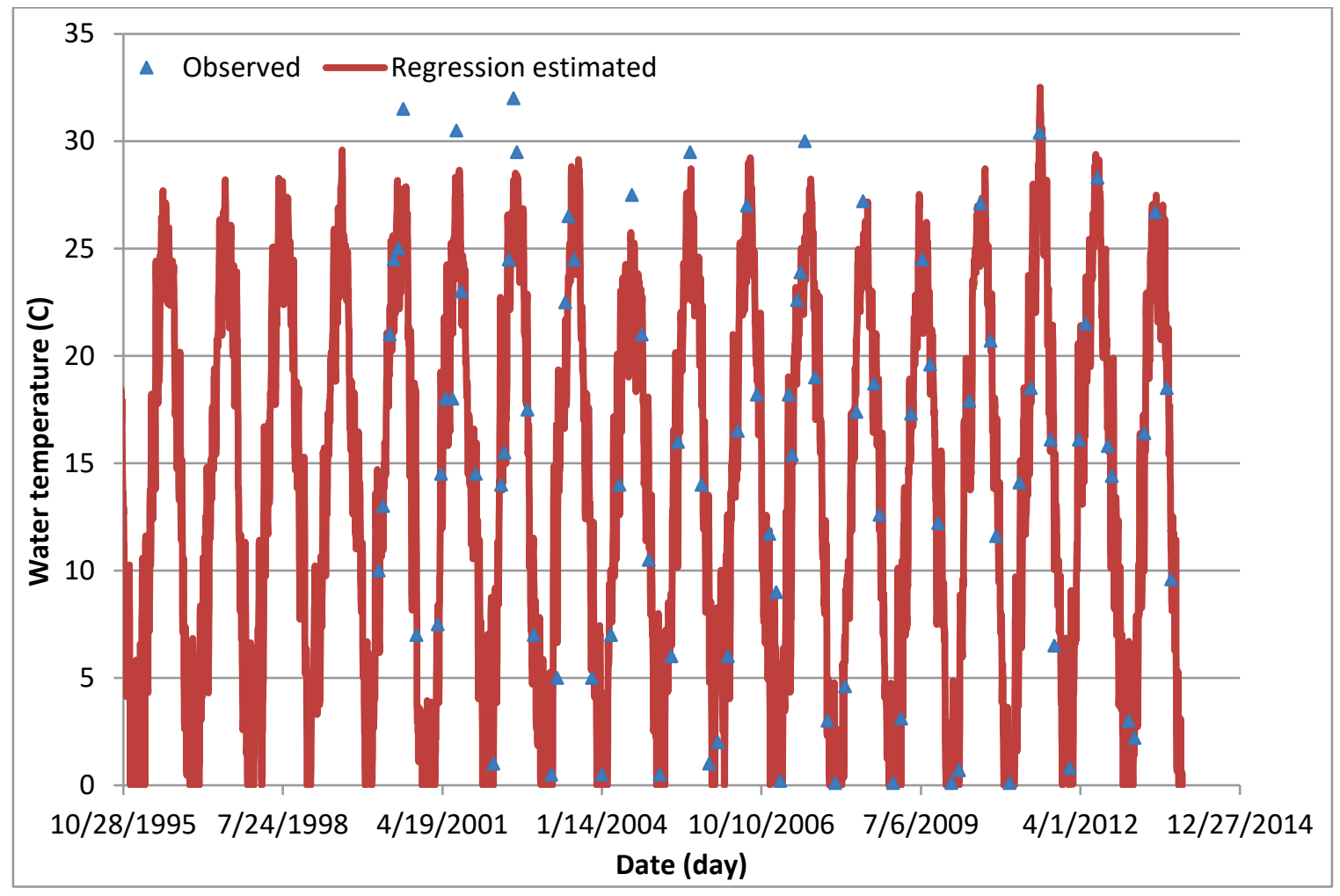


Figure B16. Regression computed versus observed water temperatures at BC16.

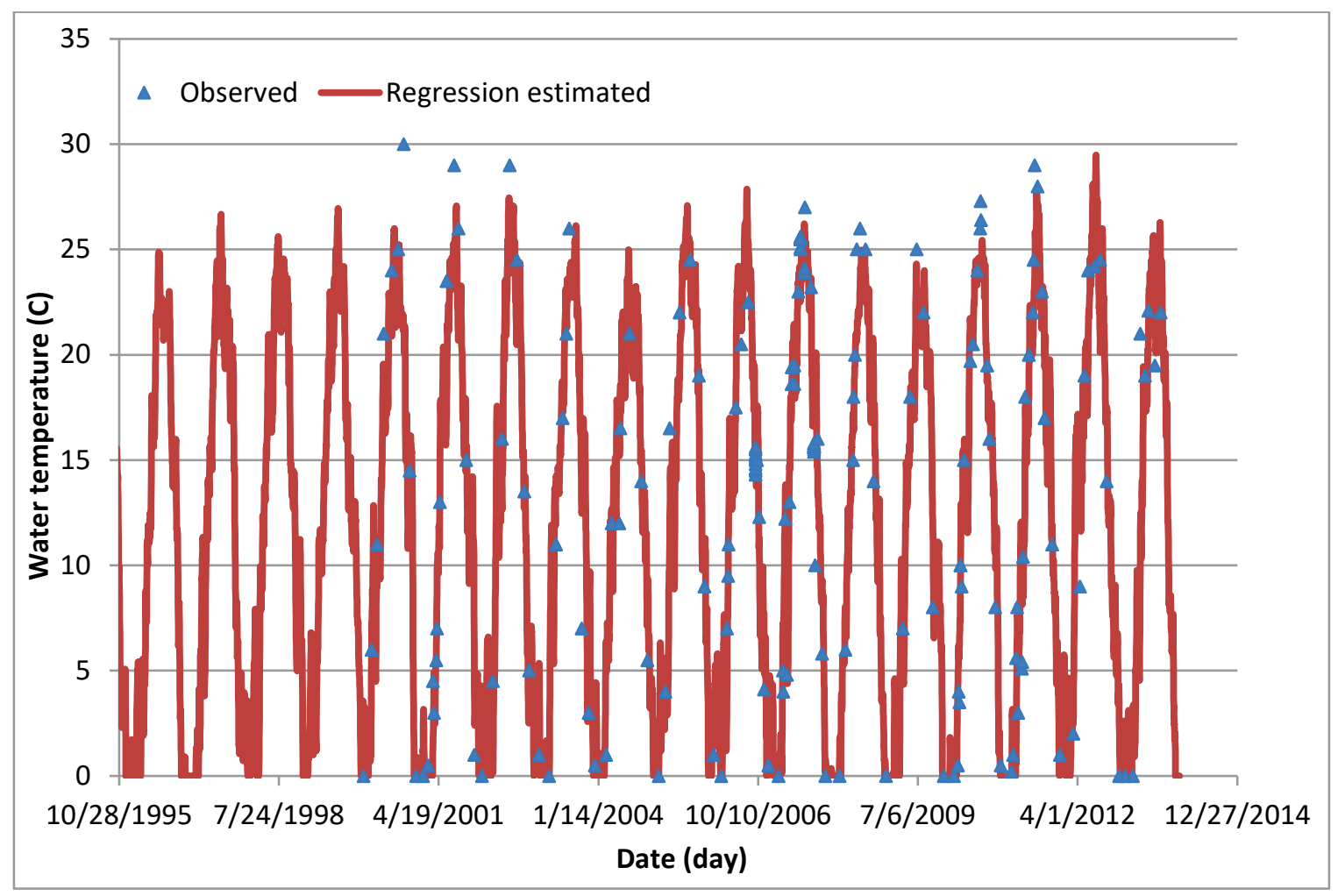




\section{Appendix C: Time Series Plots of Regression Computed versus Observed Water Temperatures for the Rulo to the mouth of the Missouri River}

Figures $\mathrm{C} 1$-C27 present 18 year (1995-2012) time series plots of regression computed and observed inflow boundary water temperatures for the HEC-RAS model from Rulo to the mouth of the Missouri River.

Figure C1. Regression computed versus observed water temperatures at BC1.

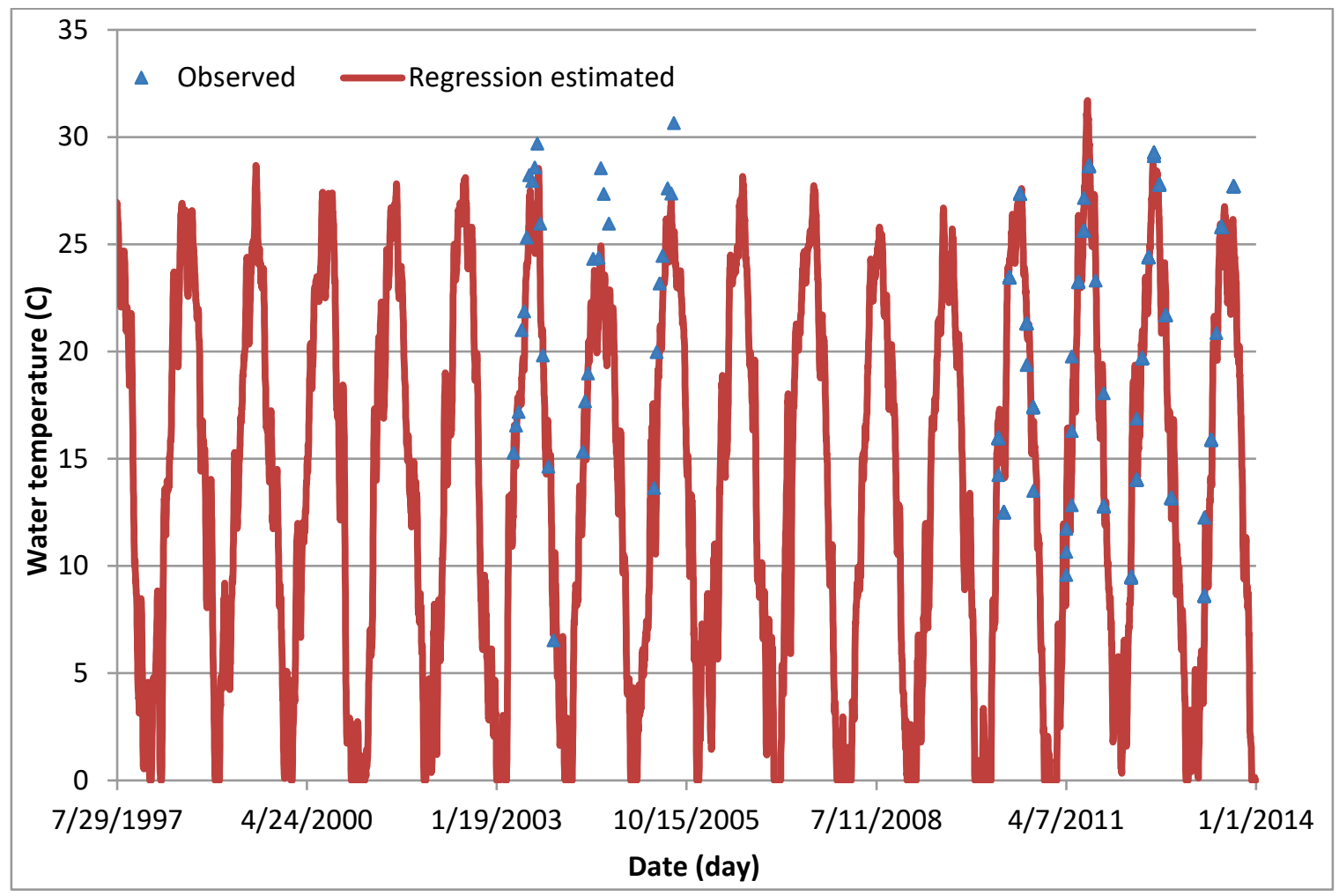


Figure C2. Regression computed versus observed water temperatures at BC2.

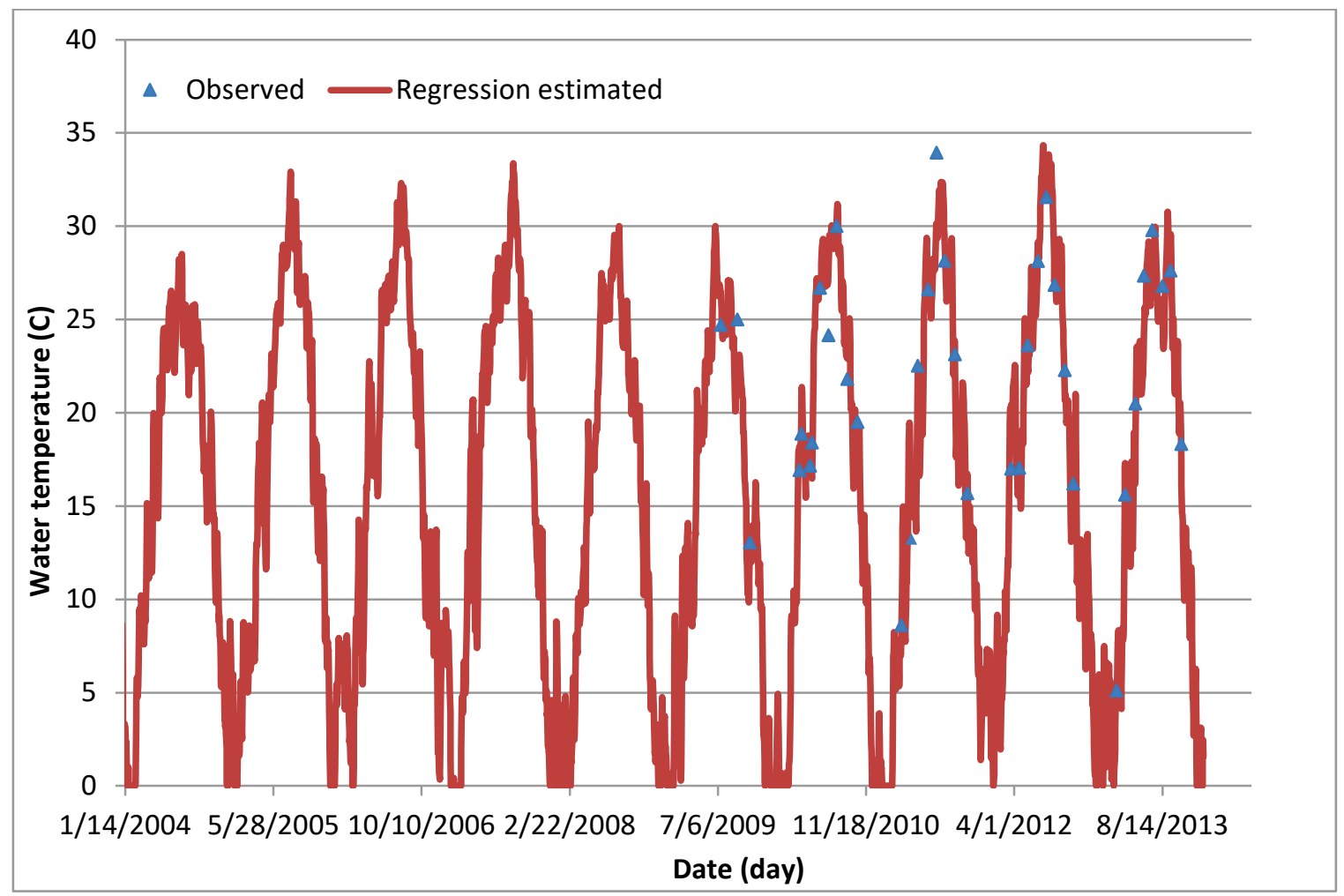

Figure C3. Regression computed versus observed water temperatures at BC3.

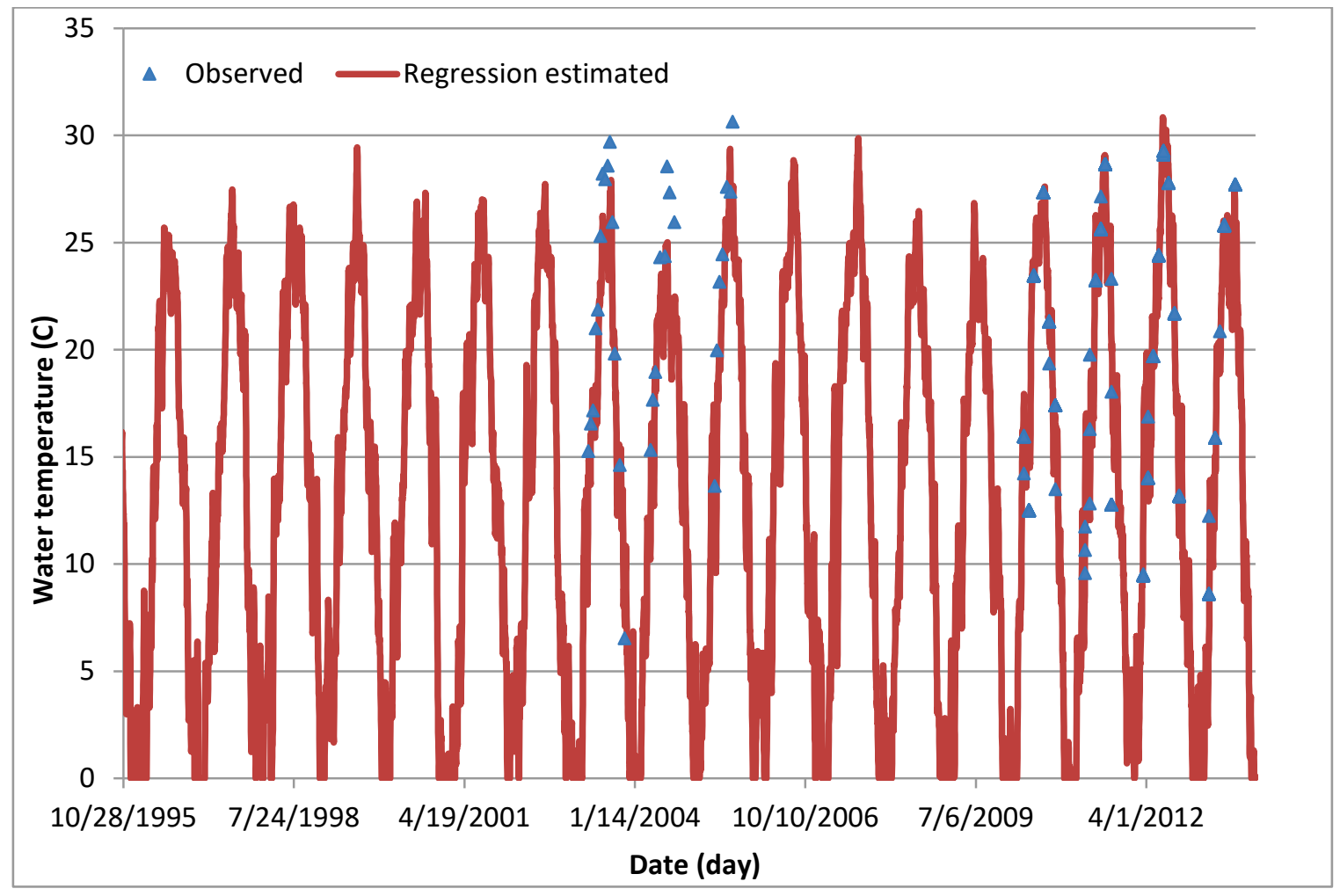


Figure C4. Regression computed versus observed water temperatures at BC4.

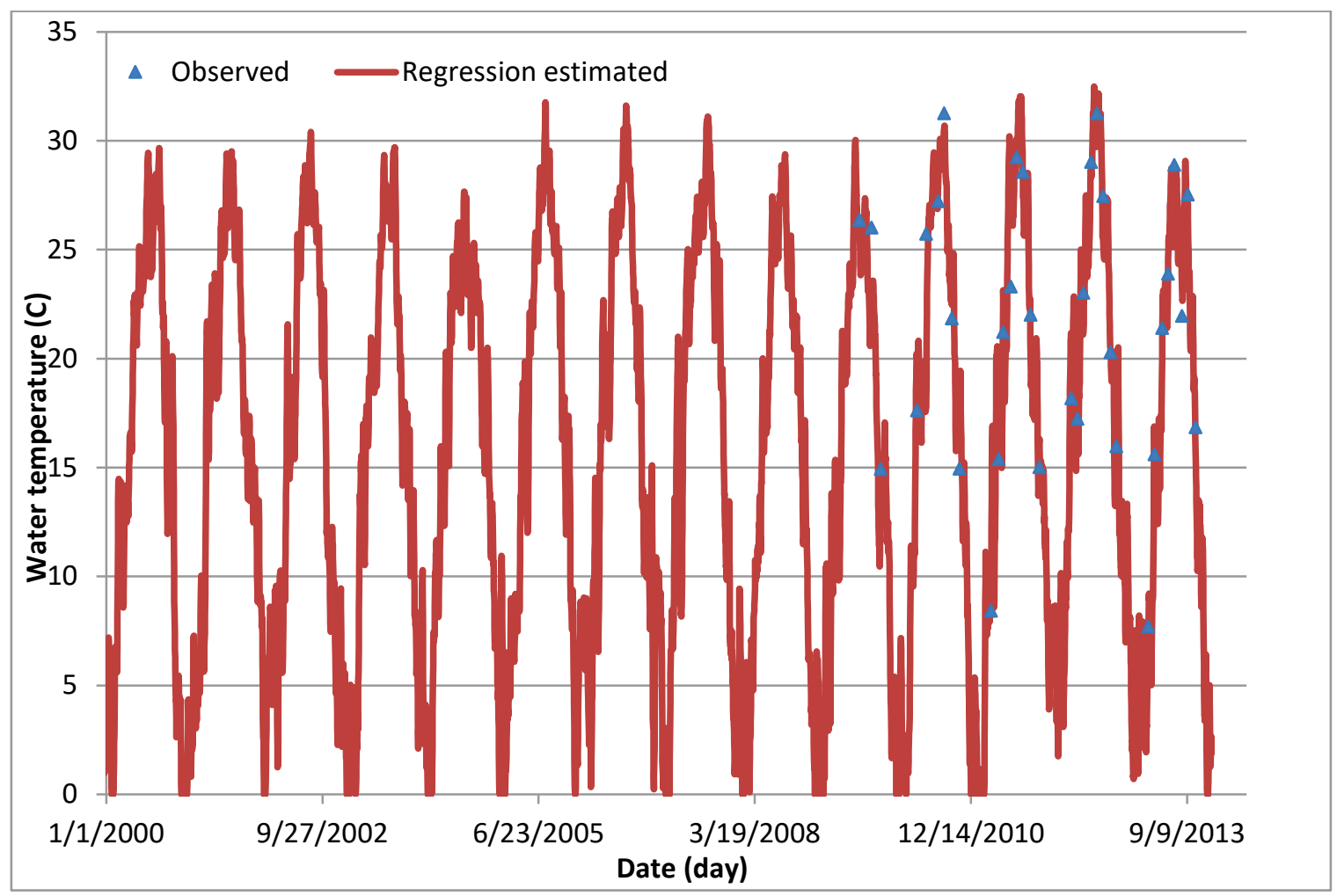

Figure C5. Regression computed versus observed water temperatures at BC5.

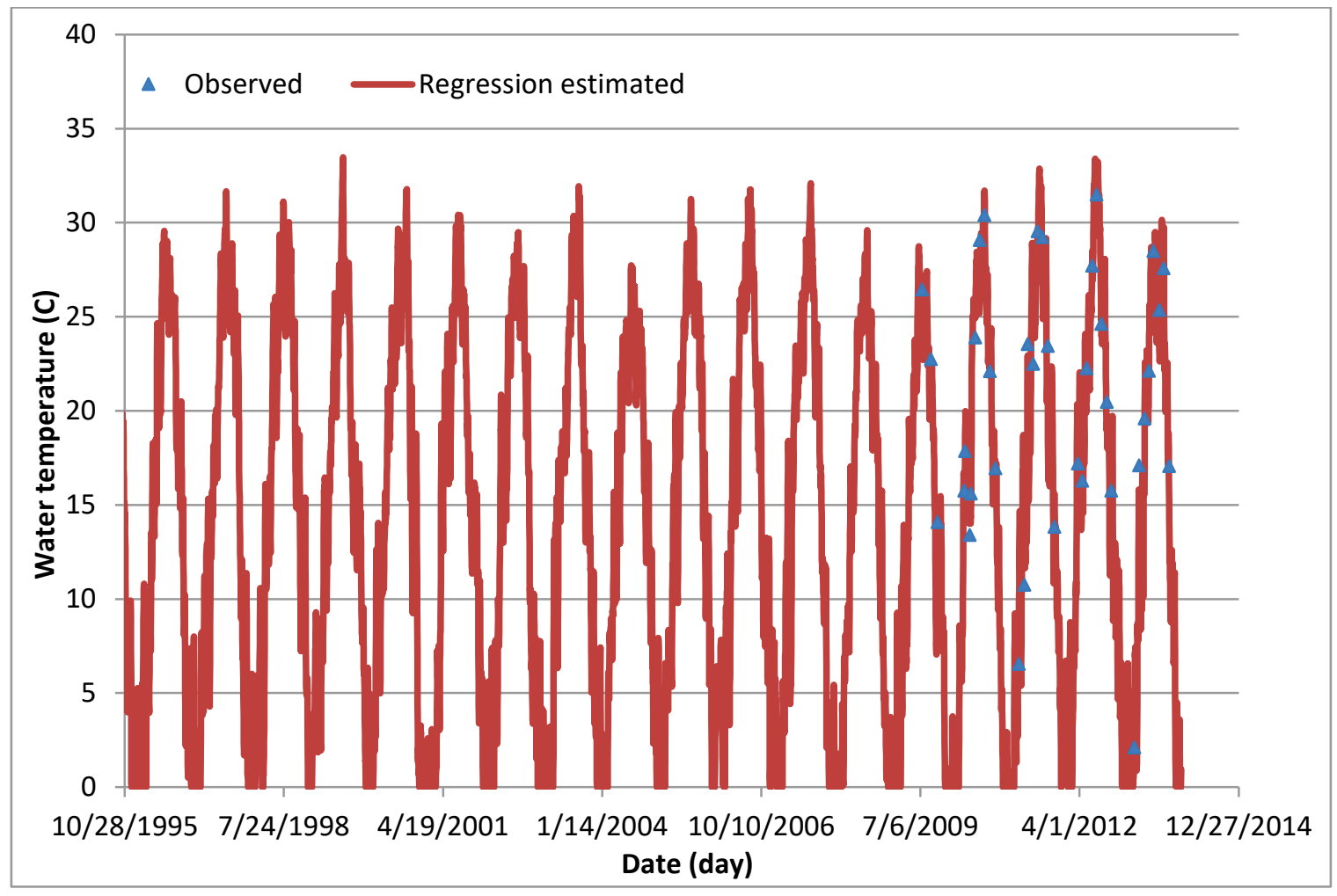


Figure C6. Regression computed versus observed water temperatures at BC6.

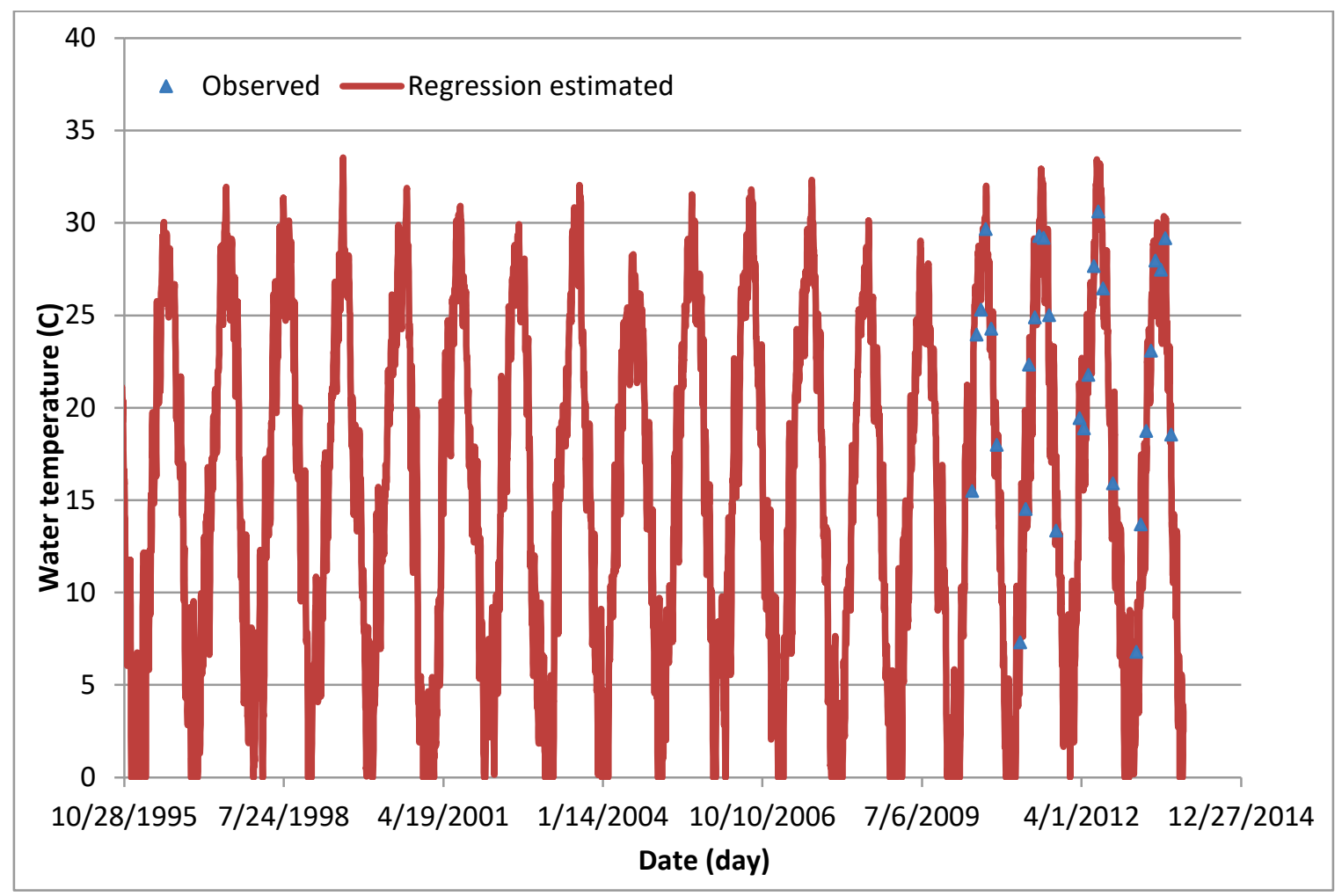

Figure $\mathrm{C}$. Regression computed versus observed water temperatures at BC7.

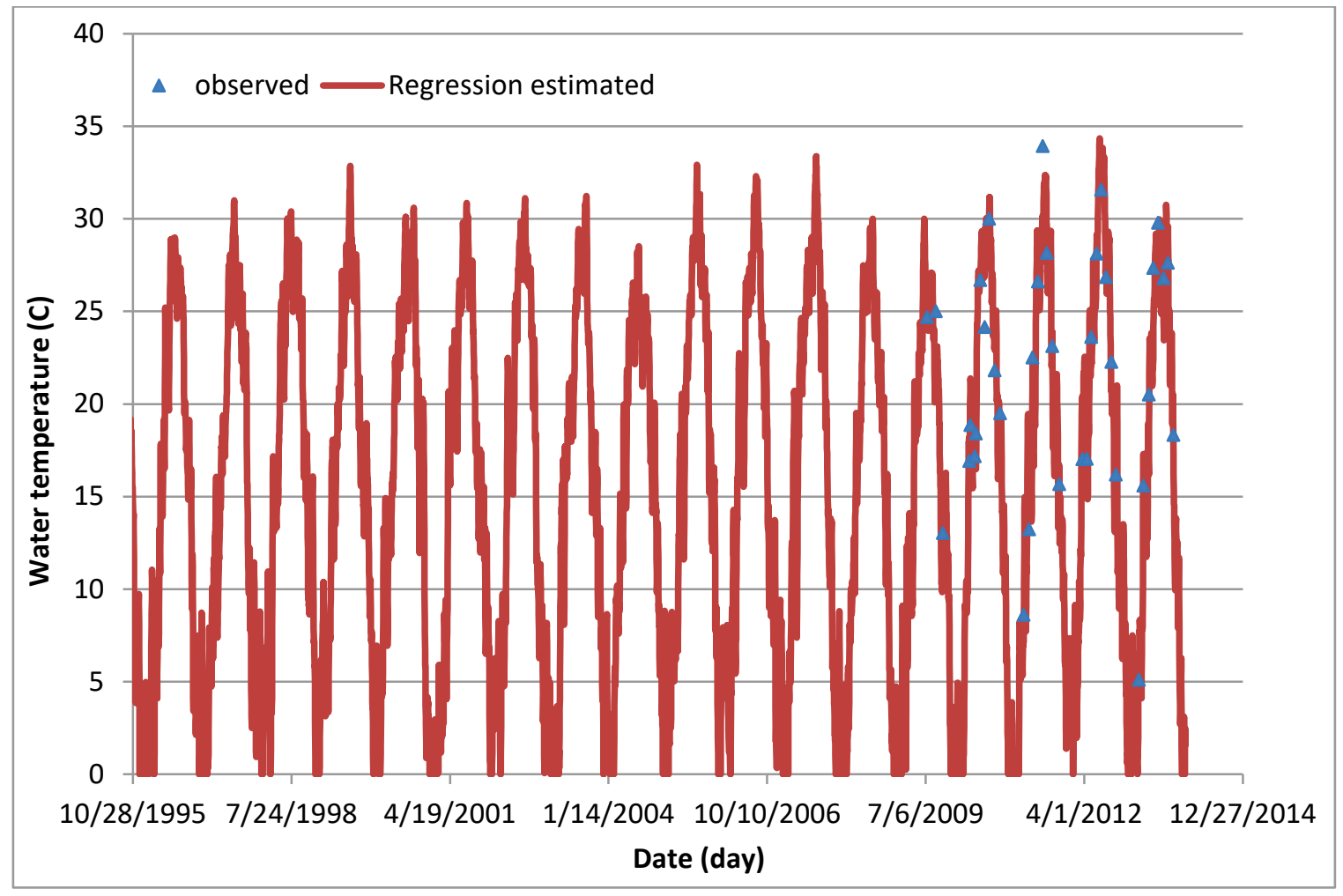


Figure C8. Regression computed versus observed water temperatures at BC8.

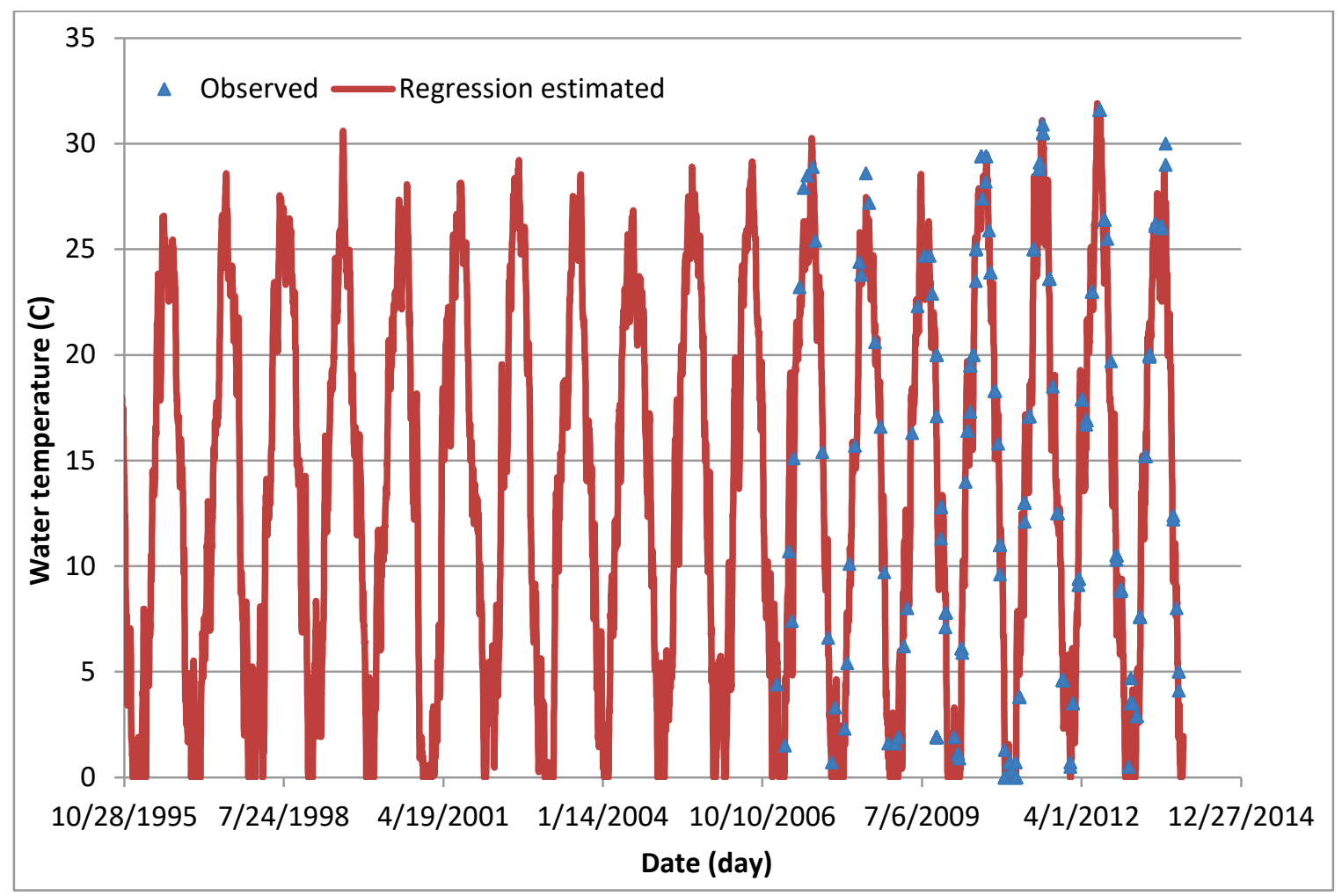

Figure C9. Regression computed versus observed water temperatures at BC9.

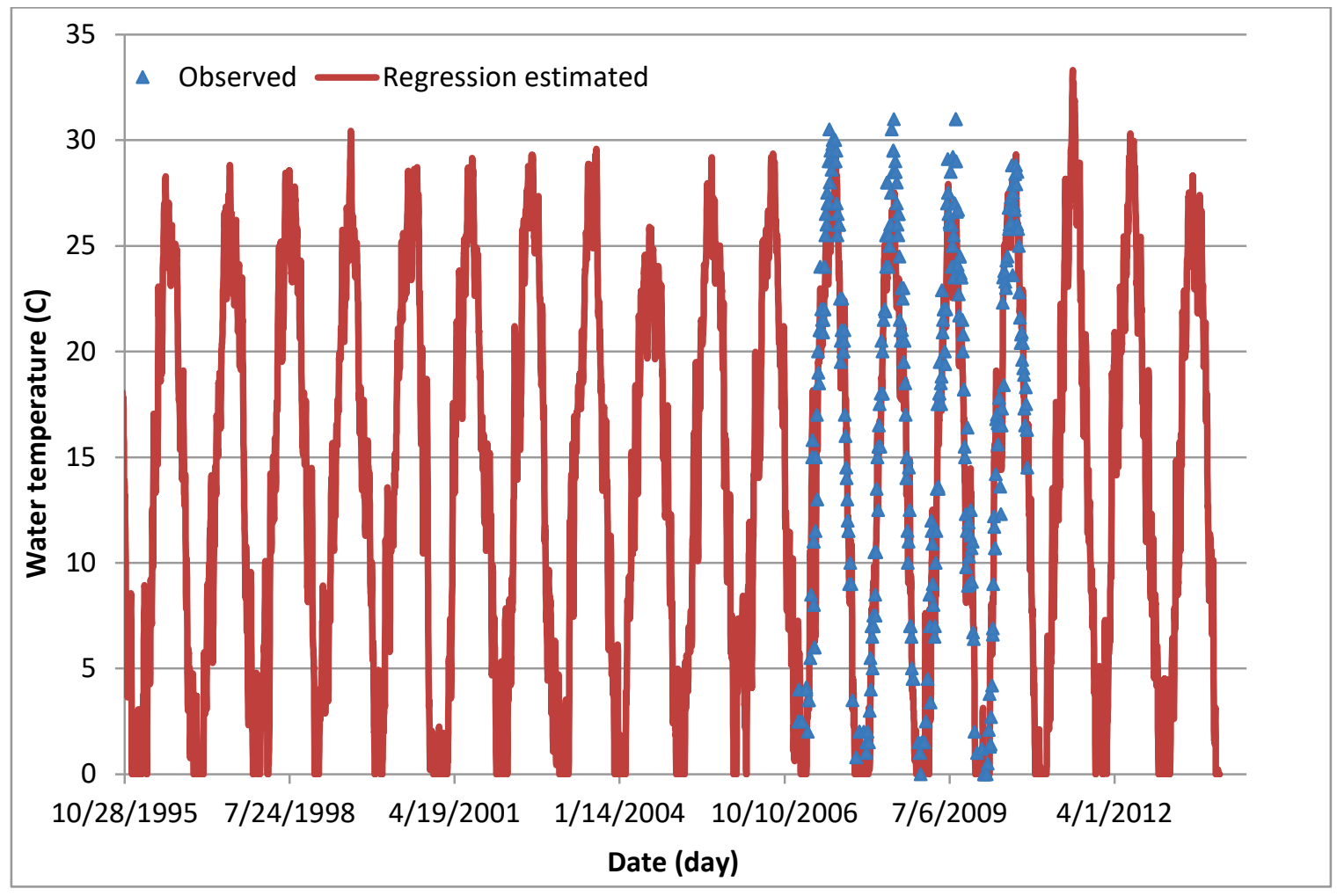


Figure C10. Regression computed versus observed water temperatures at BC10.

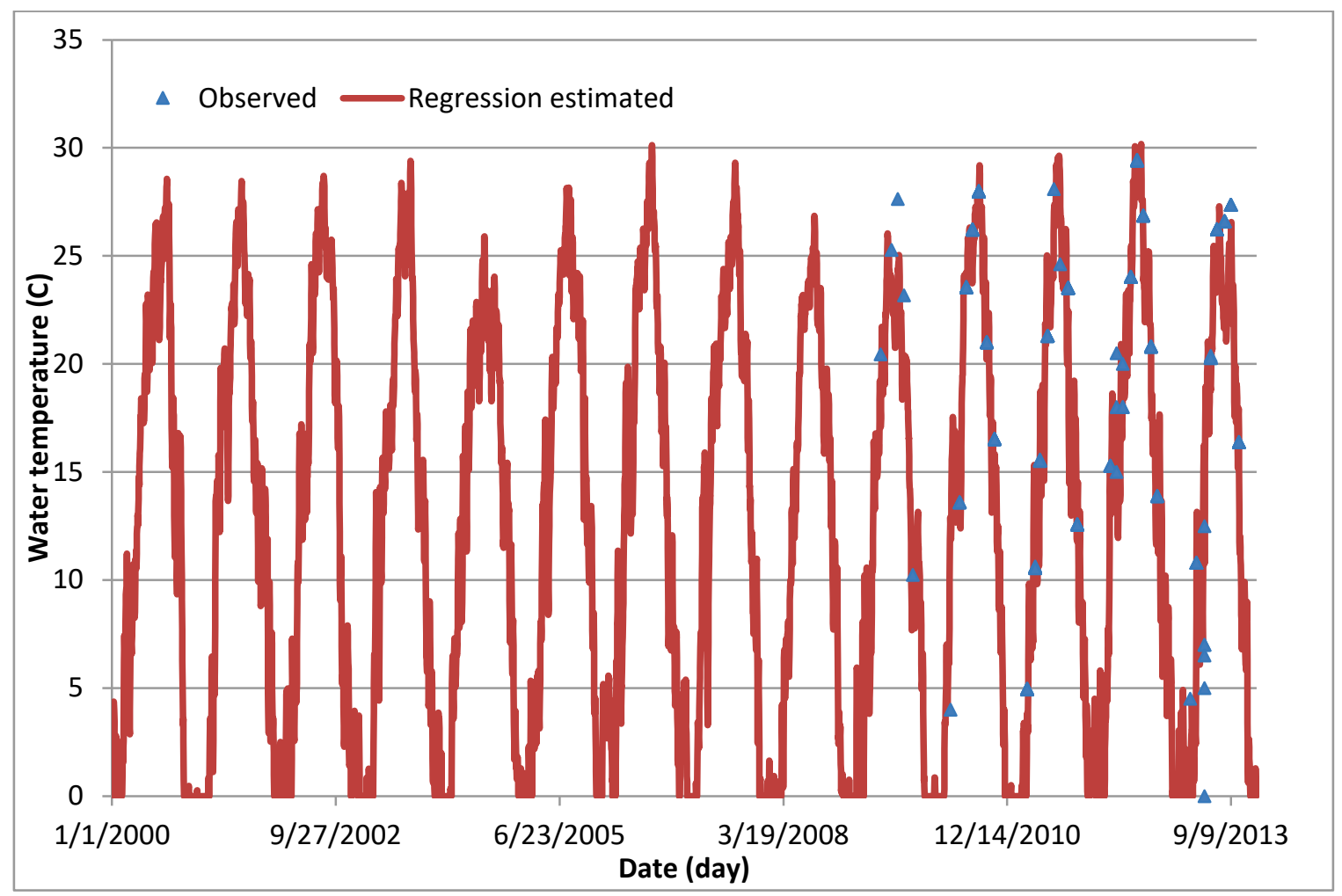

Figure C11. Regression computed versus observed water temperatures at BC11.

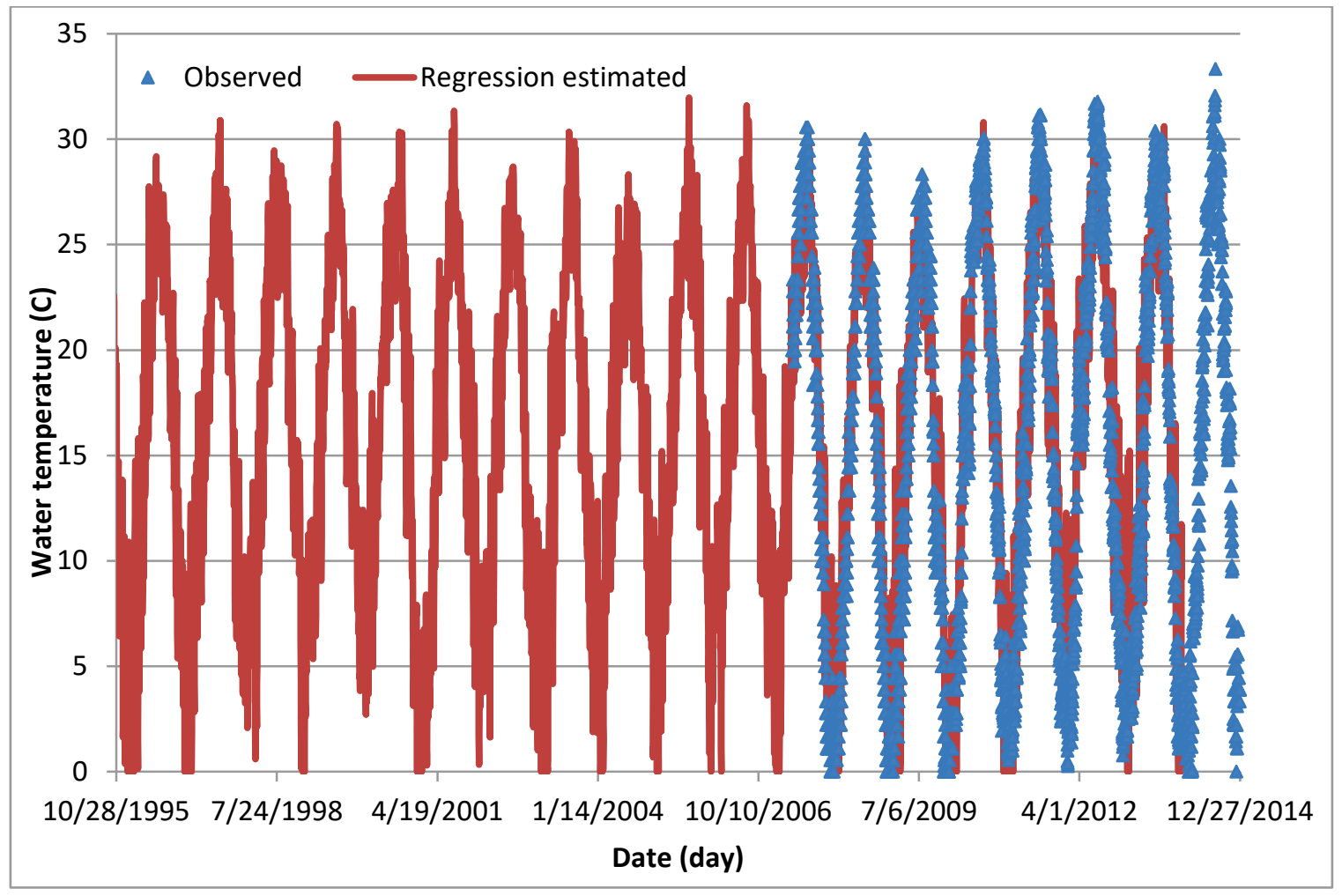


Figure C12. Regression computed versus observed water temperatures at BC12.

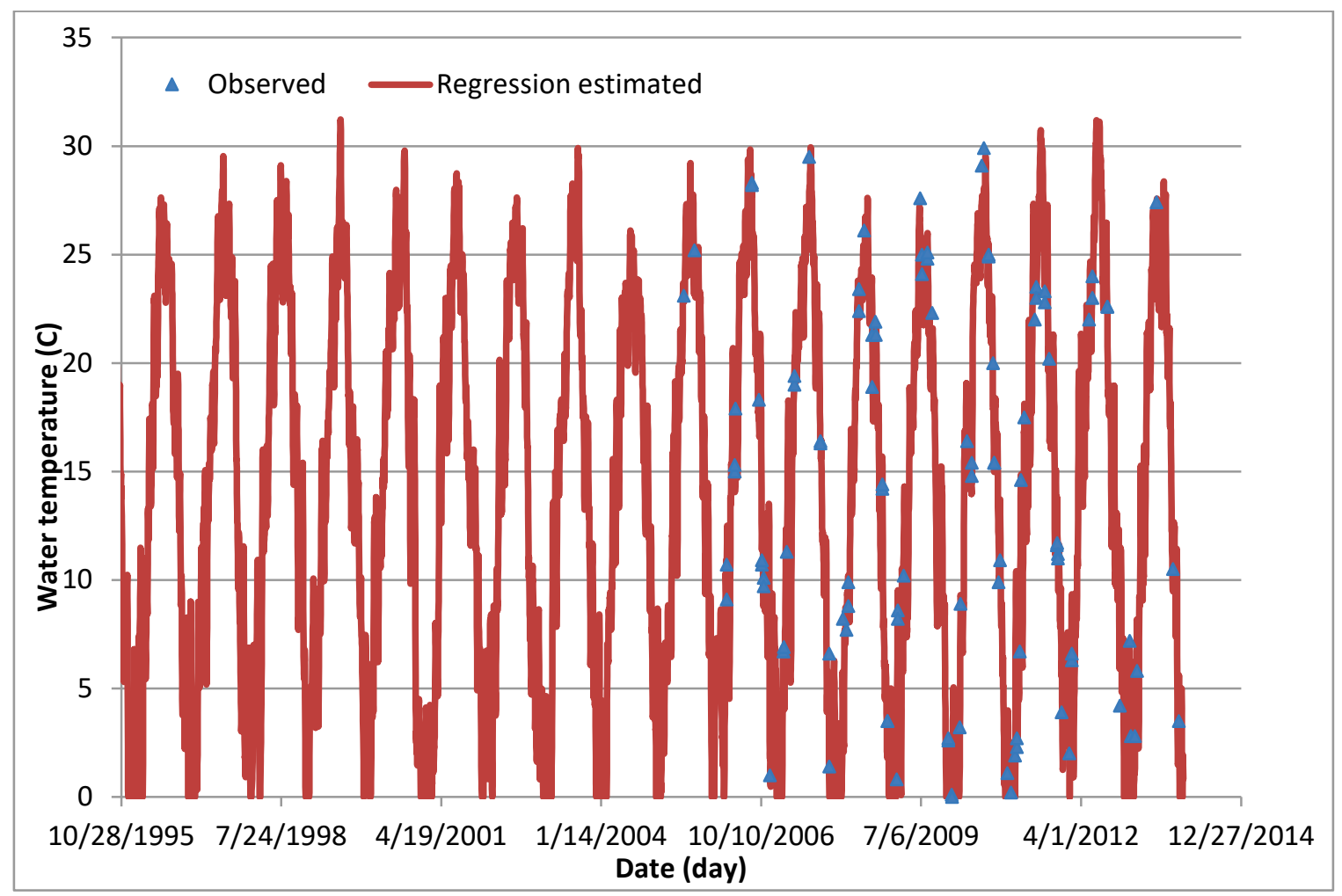

Figure C13. Regression computed versus observed water temperatures at BC13.

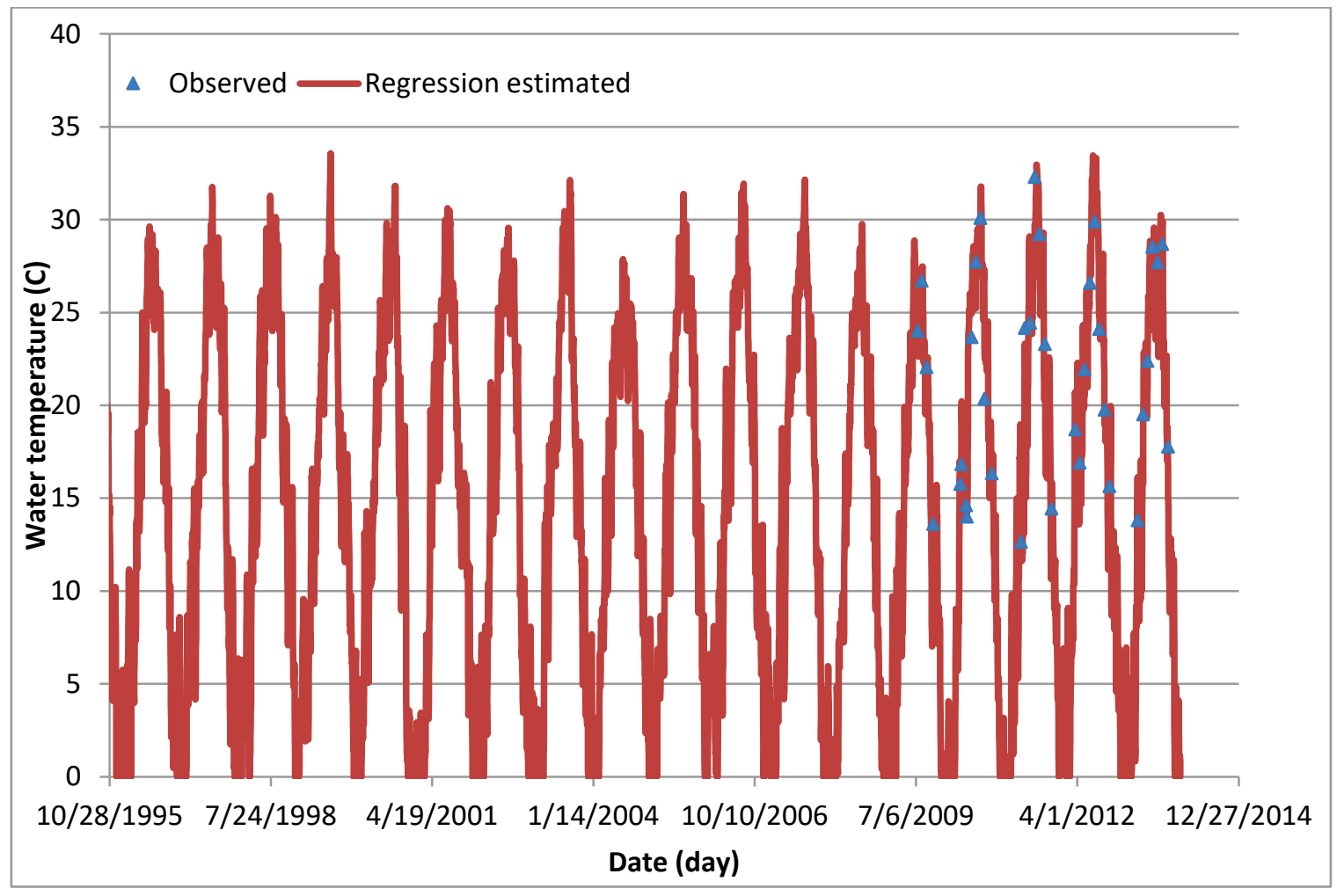


Figure C14. Regression computed versus observed water temperatures at BC14.

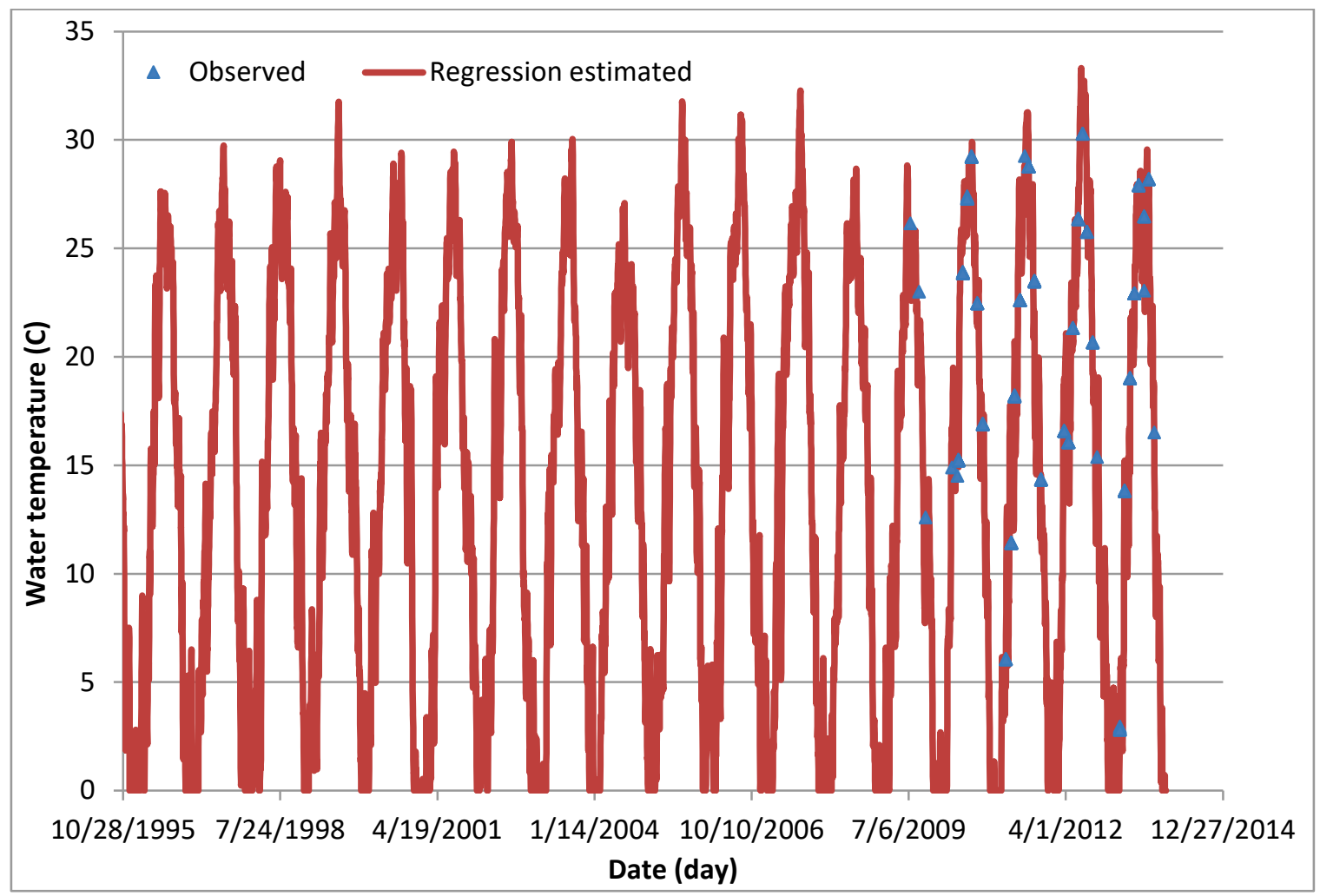

Figure C15. Regression computed versus observed water temperatures at BC15.

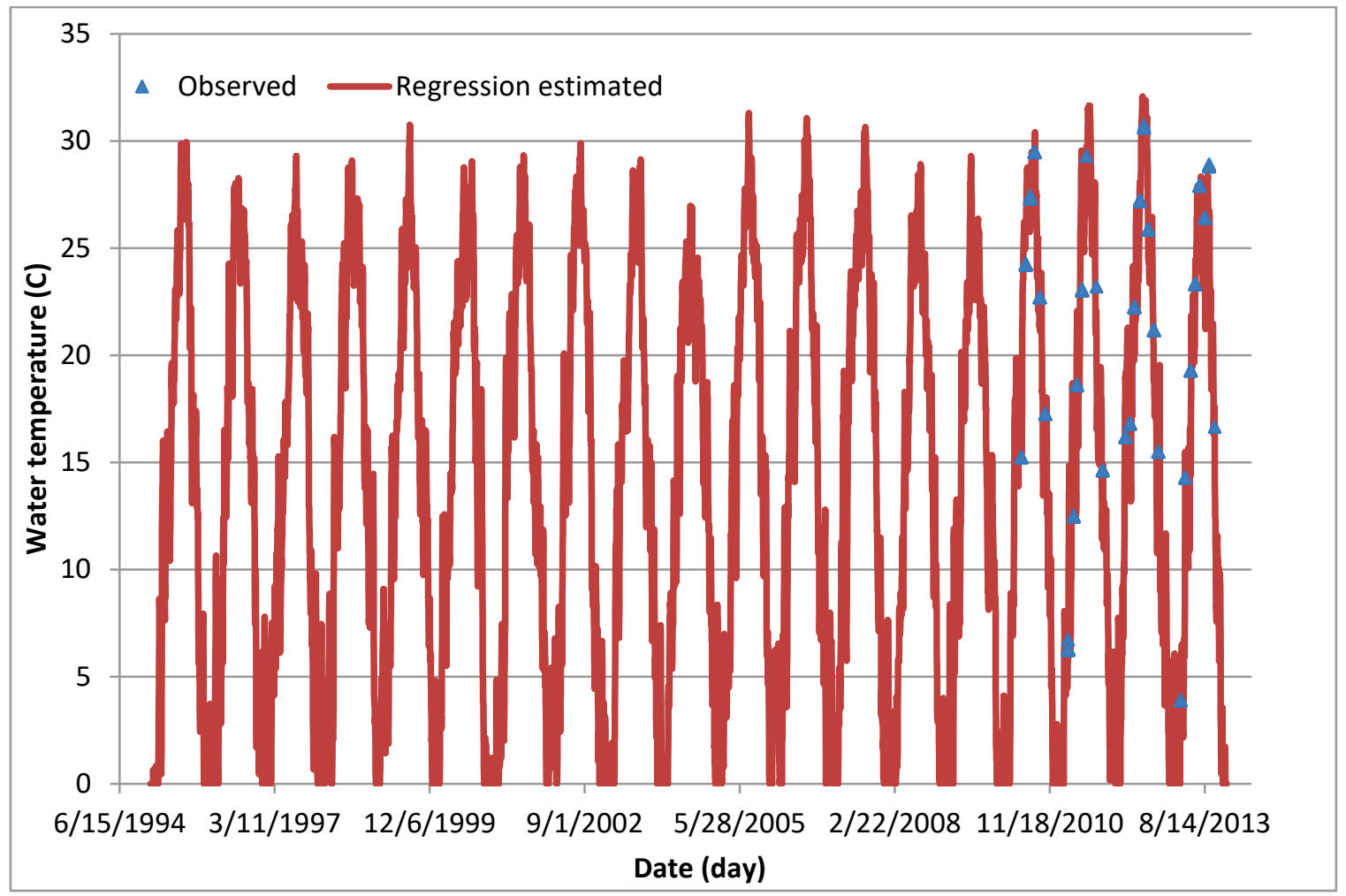


Figure C16. Regression computed versus observed water temperatures at BC16.

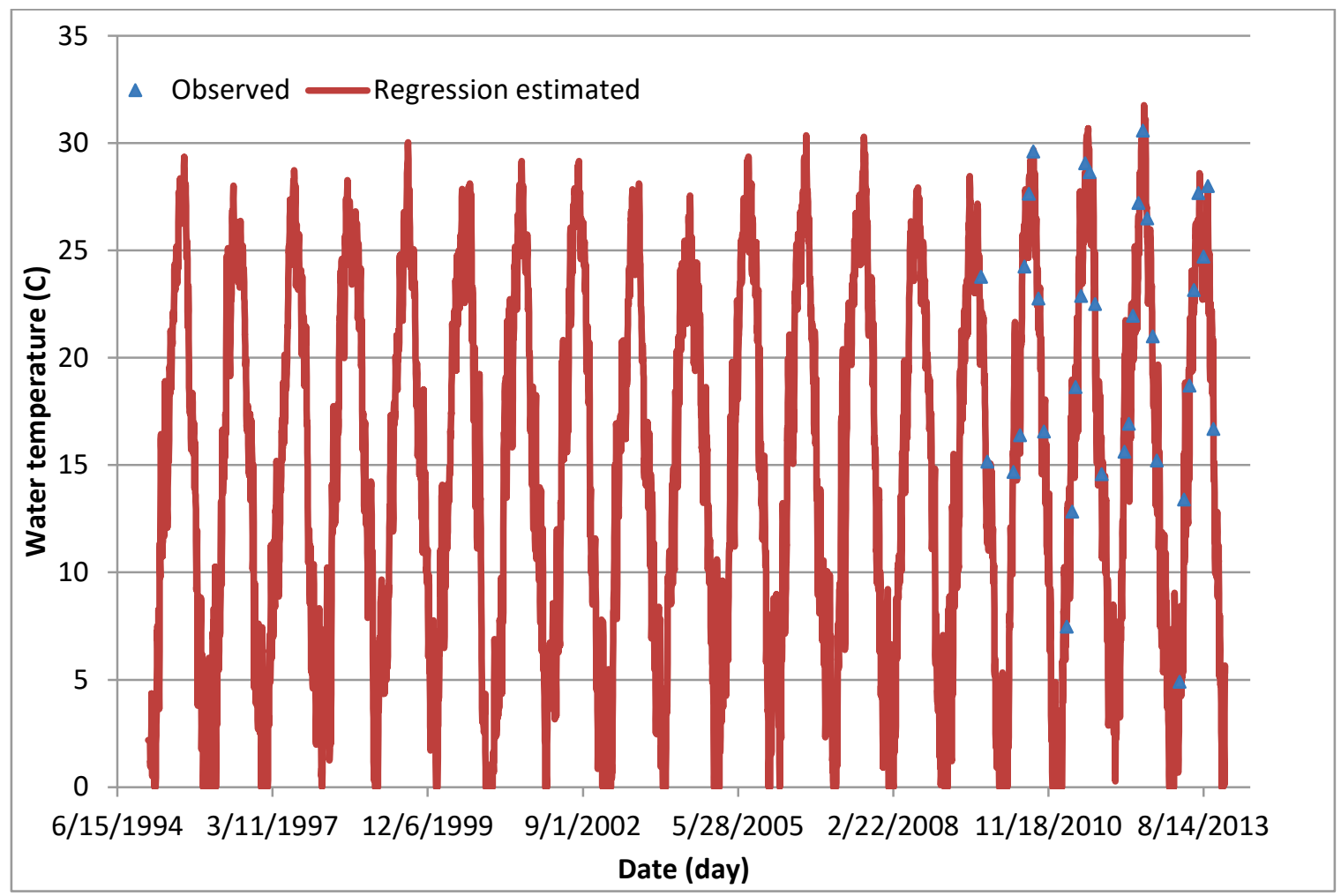

Figure C17. Regression computed versus observed water temperatures at BC17.

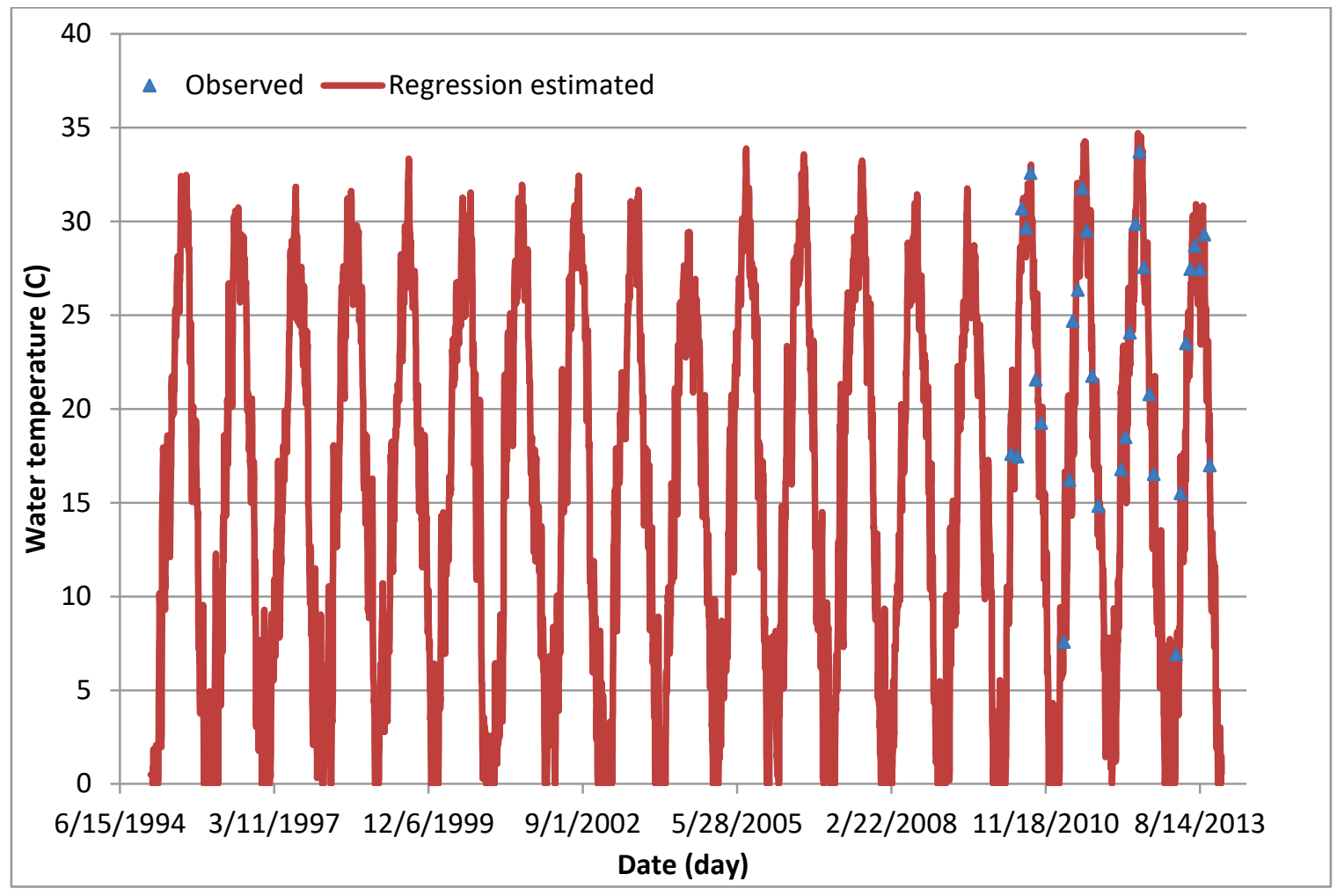


Figure C18. Regression computed versus observed water temperatures at BC18.

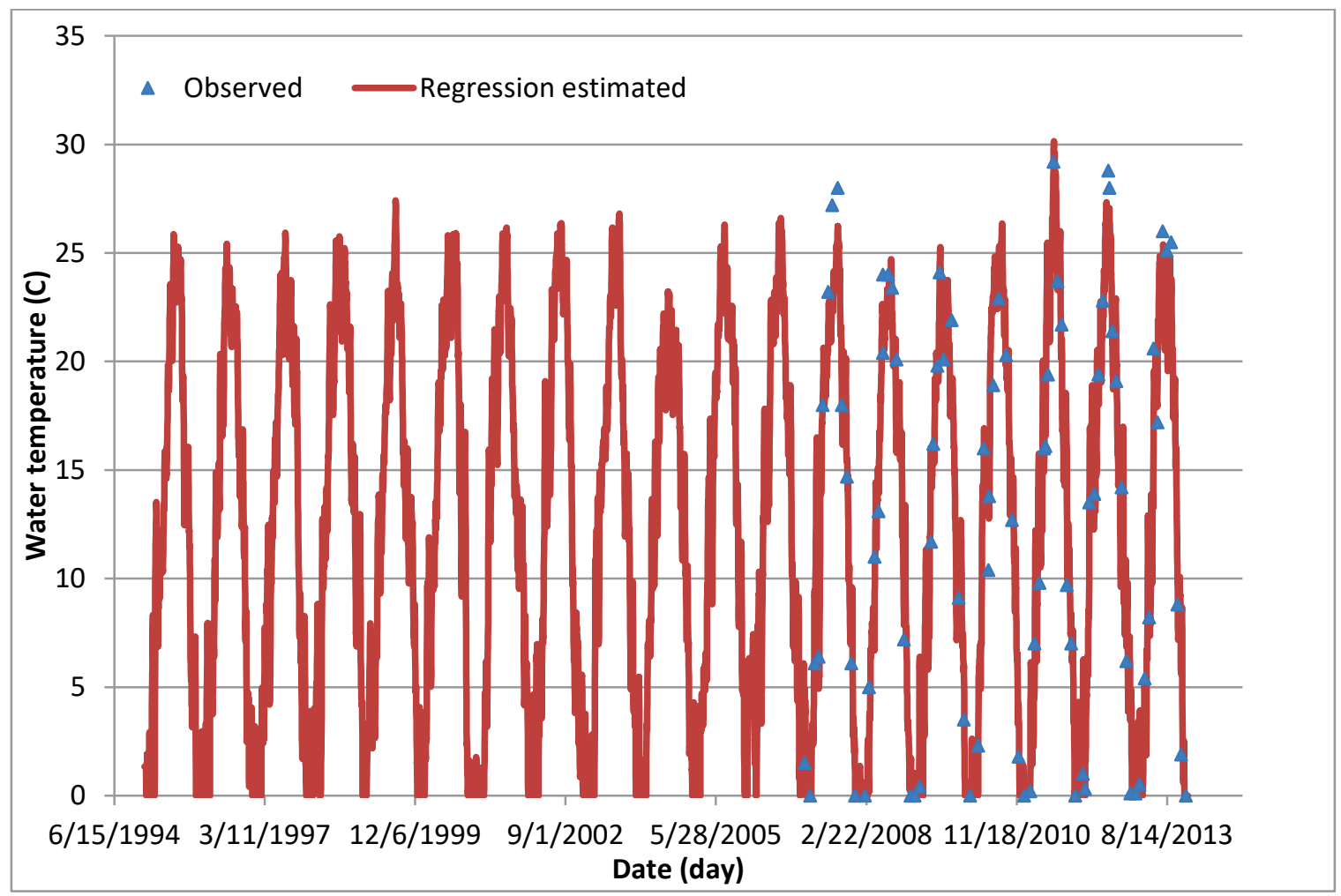

Figure C19. Regression computed versus observed water temperatures at BC19.

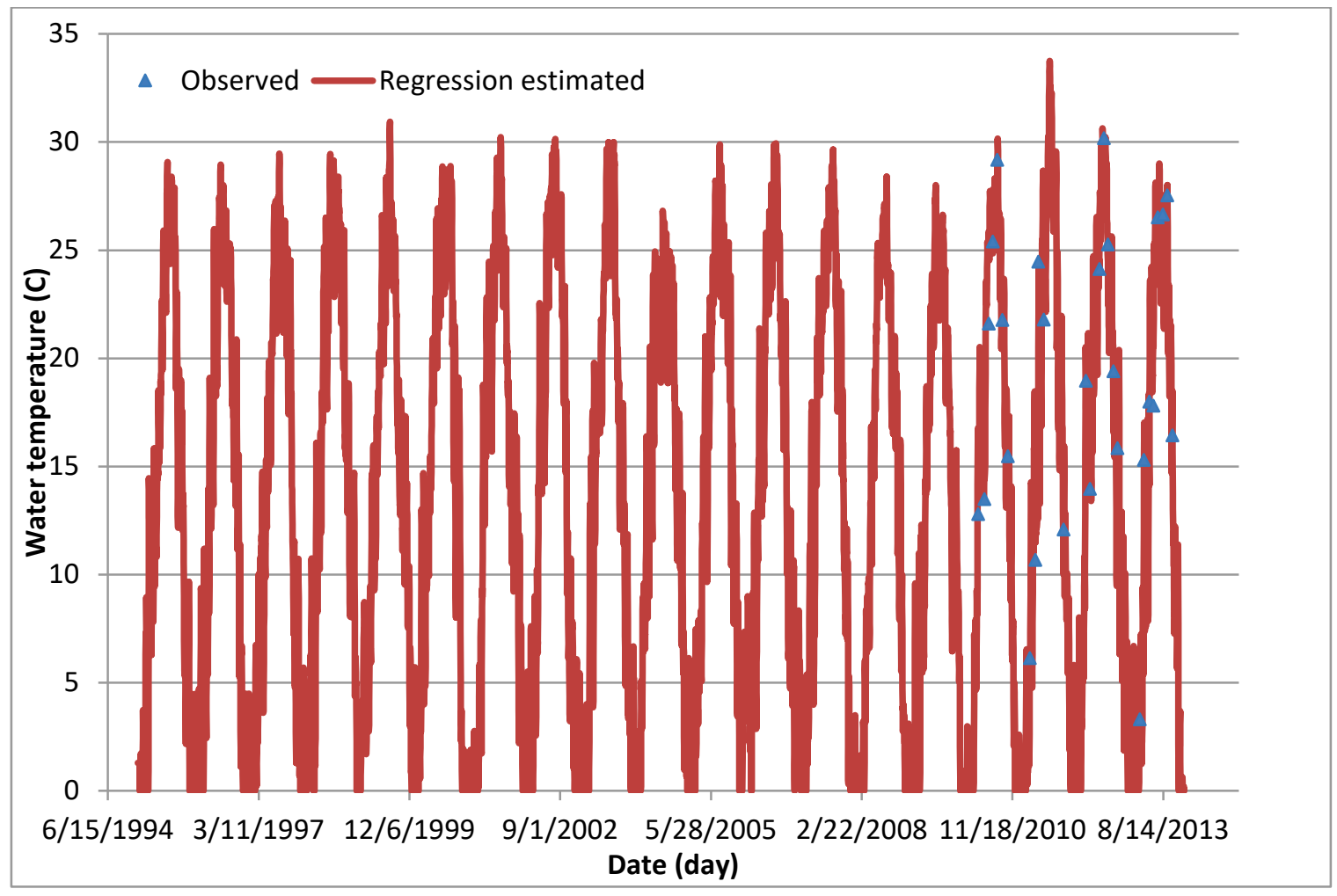


Figure C20. Regression computed versus observed water temperatures at BC20.

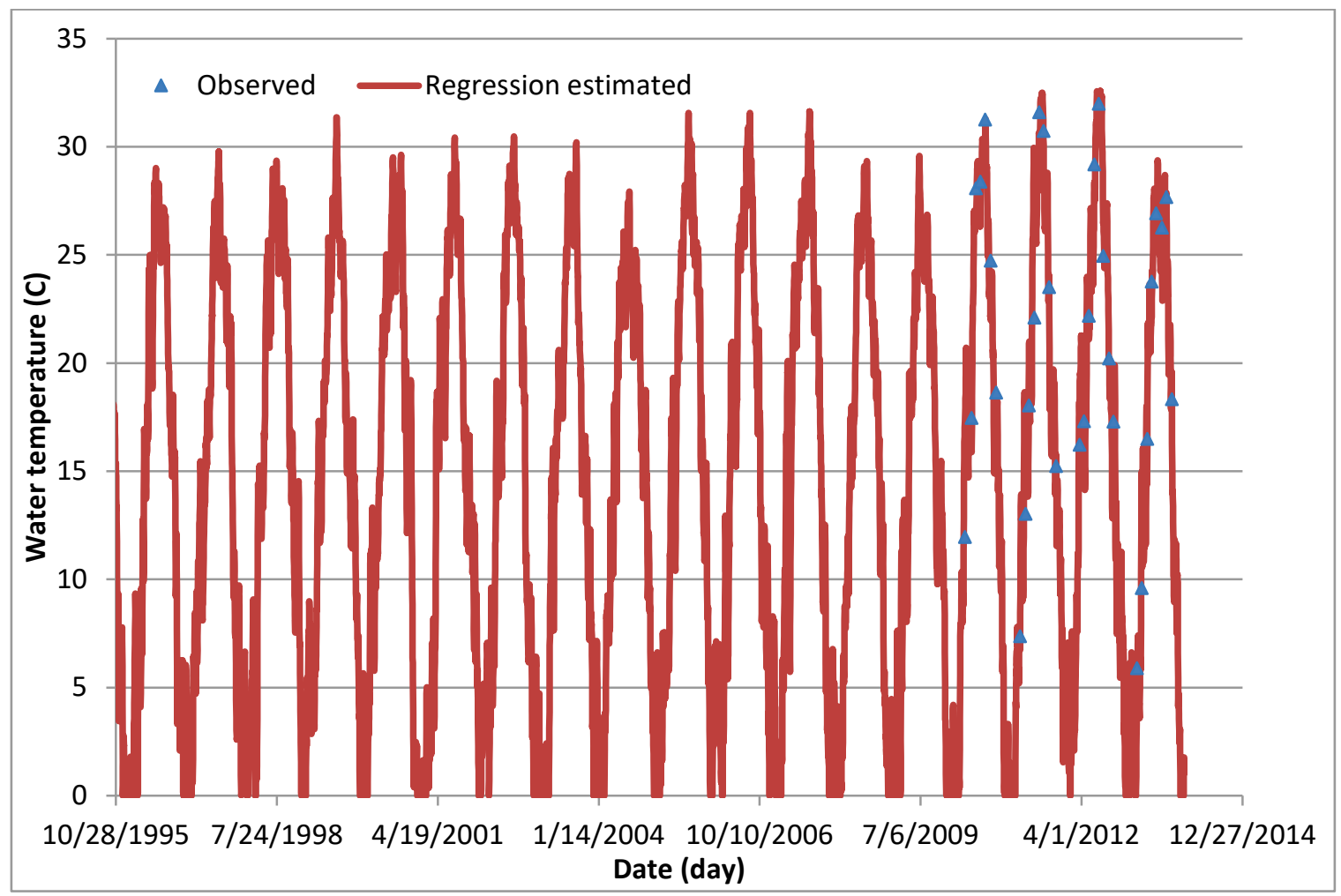

Figure C21. Regression computed versus observed water temperatures at BC21.

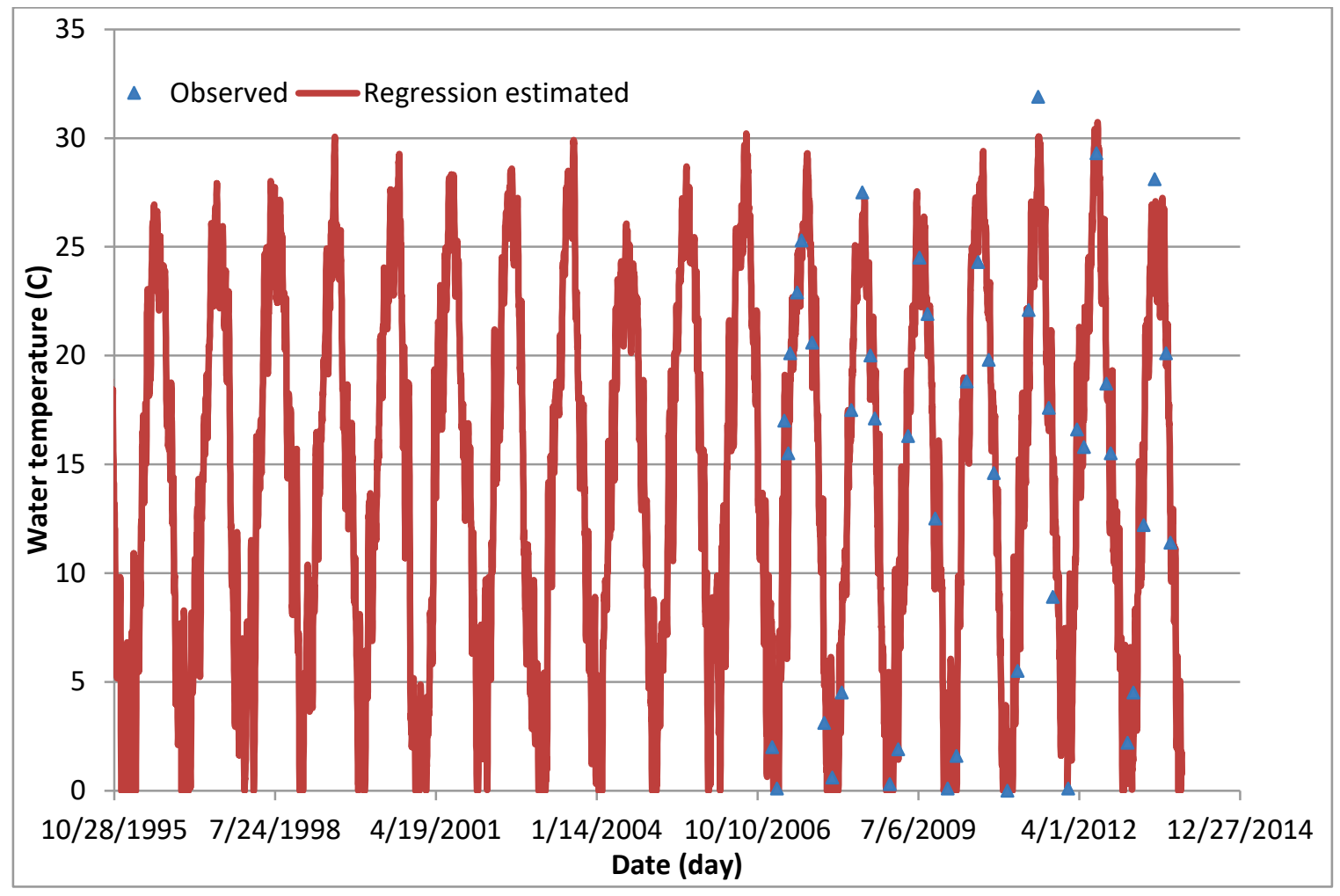


Figure C22. Regression computed versus observed water temperatures at BC22.

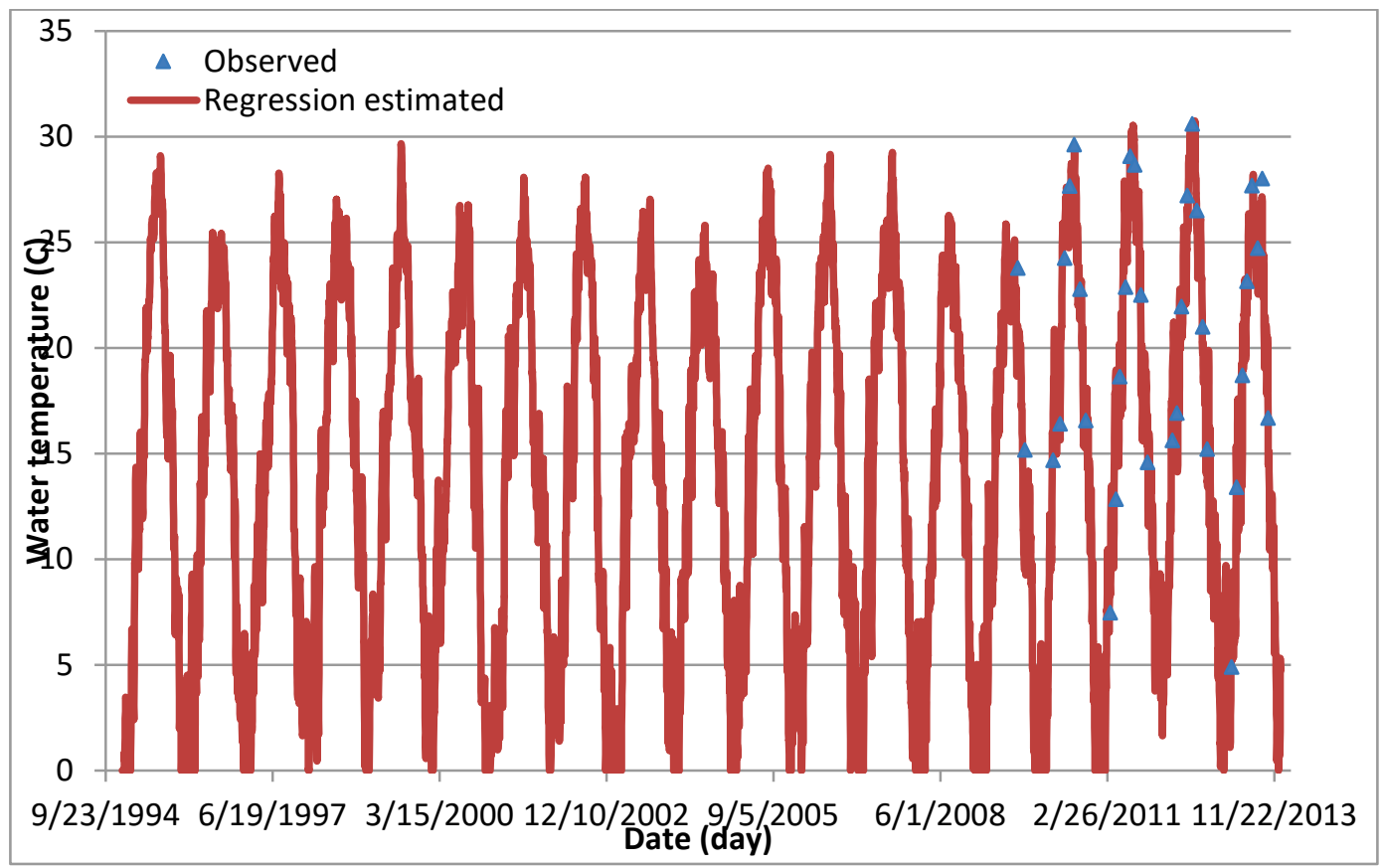

Figure C23. Regression computed versus observed water temperatures at BC23.

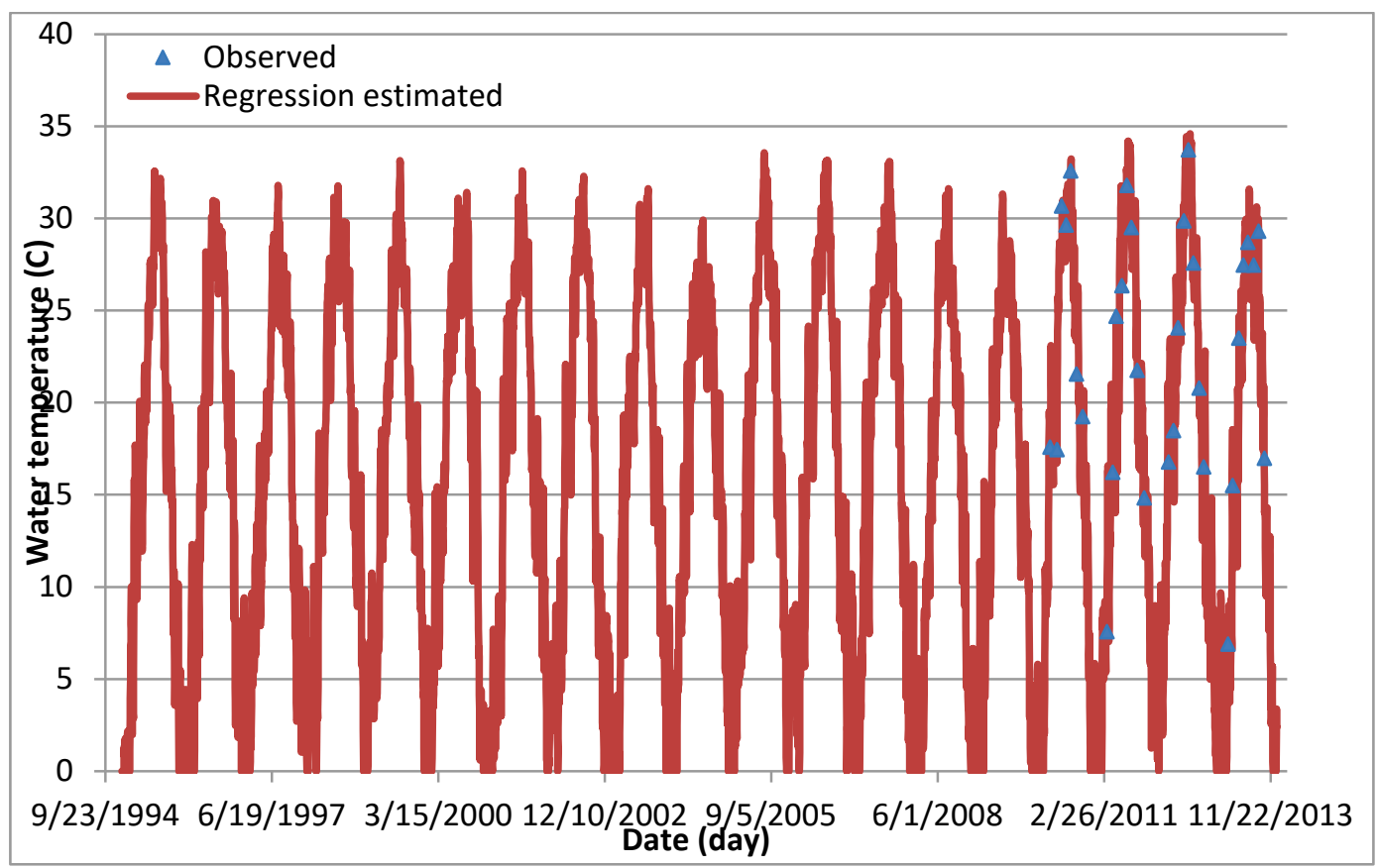


Figure C24. Regression computed versus observed water temperatures at BC24.

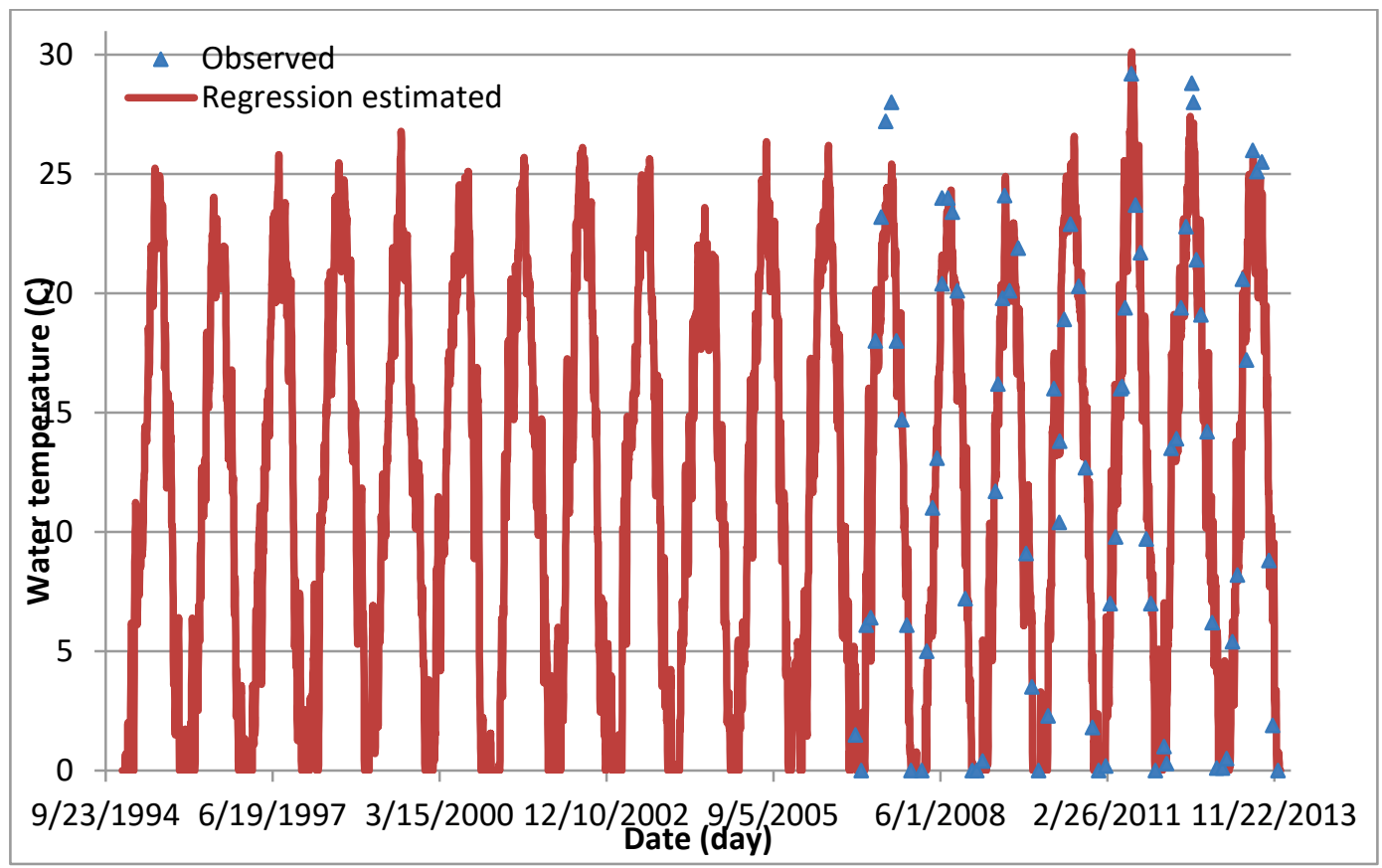

Figure C25. Regression computed versus observed water temperatures at BC25.

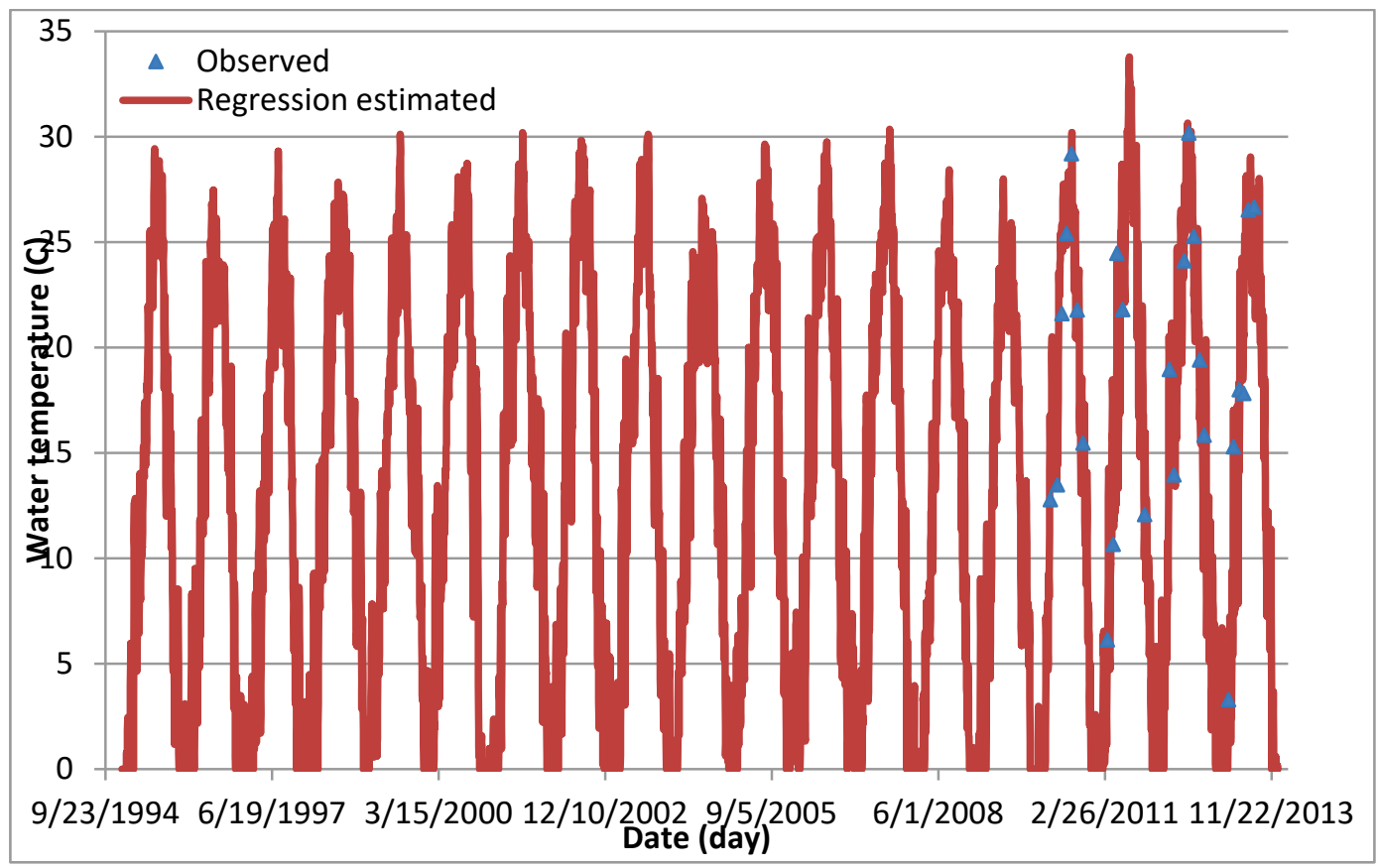


Figure C26. Regression computed versus observed water temperatures at BC26.

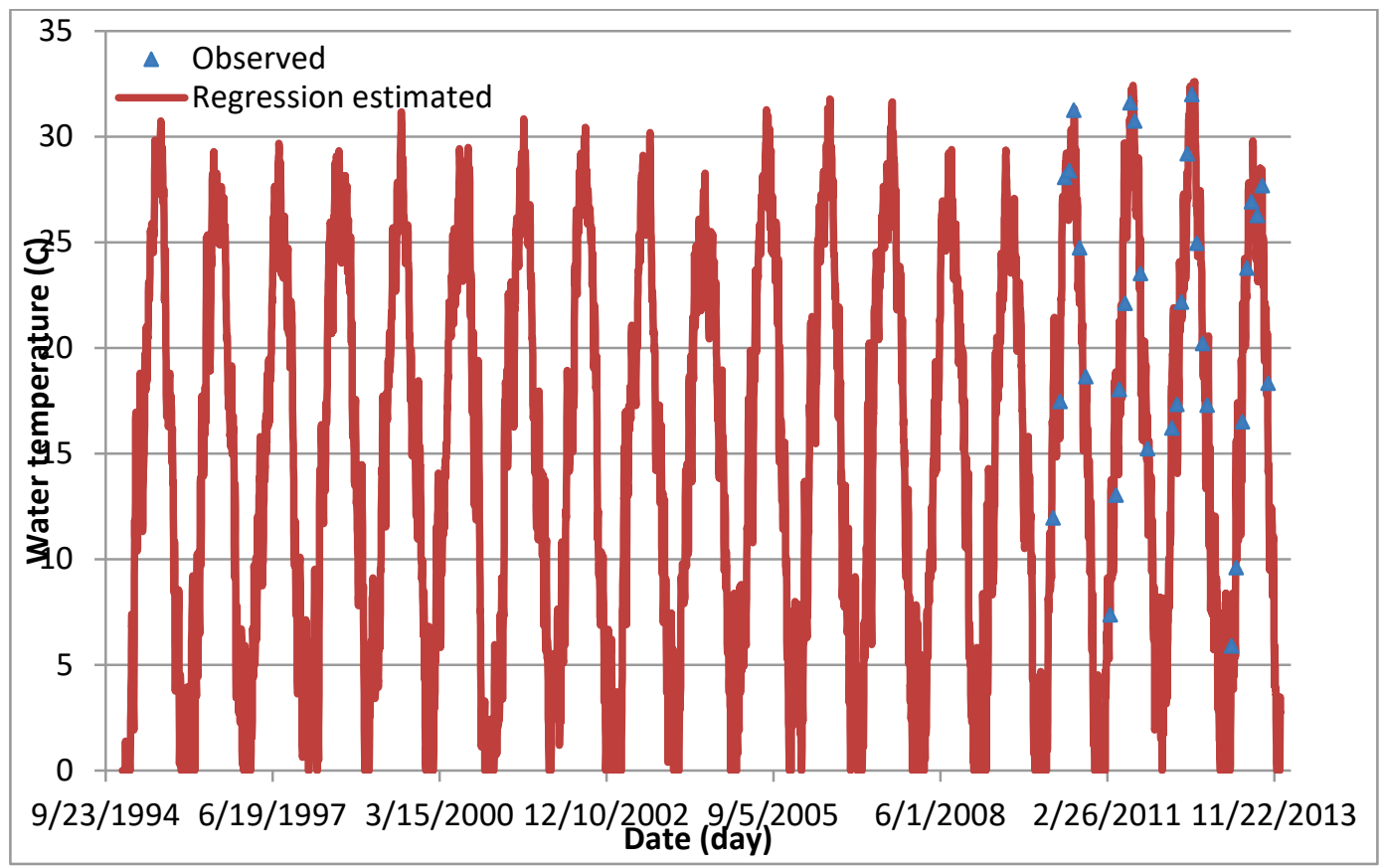

Figure C27. Regression computed versus observed water temperatures at BC27.

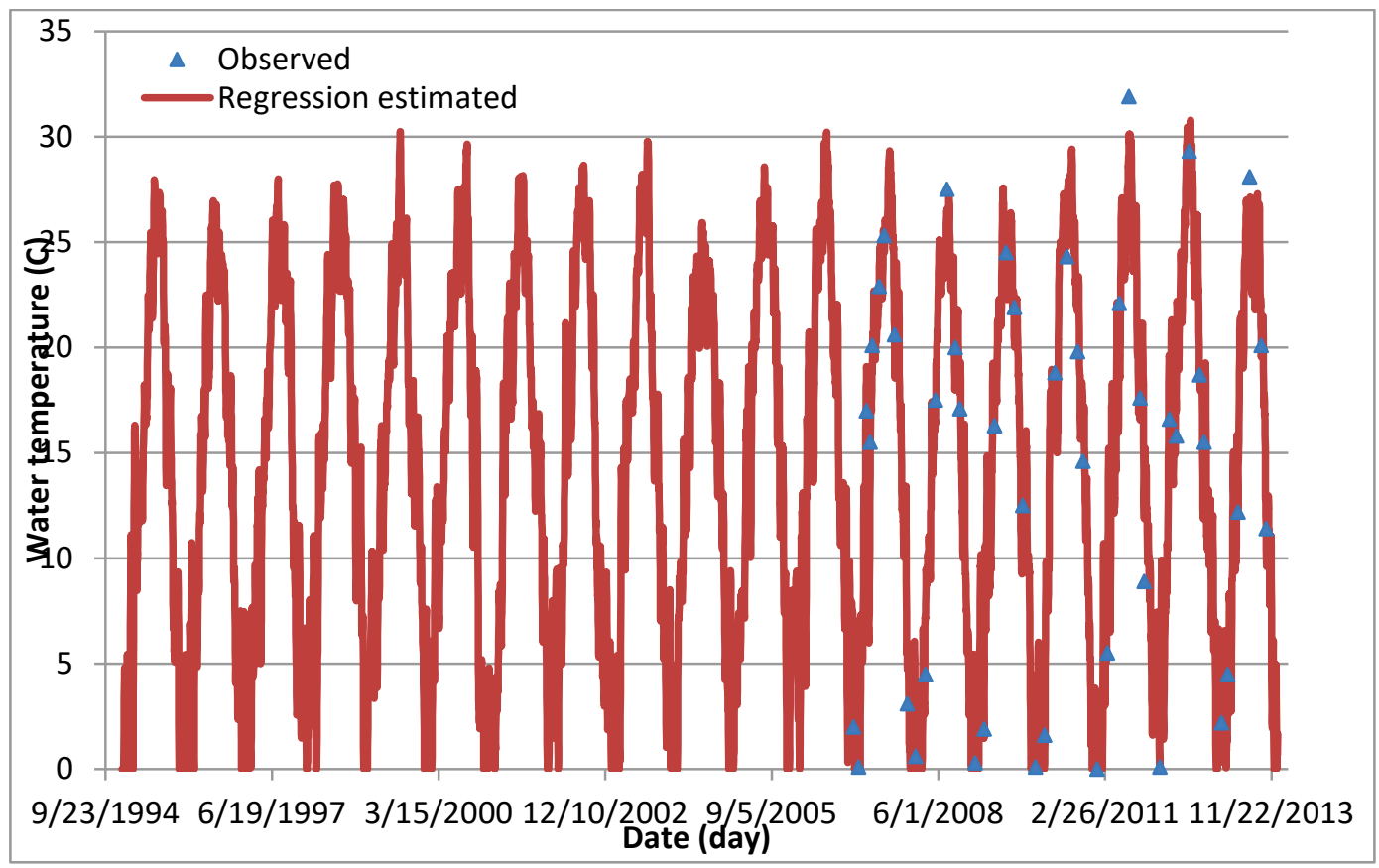




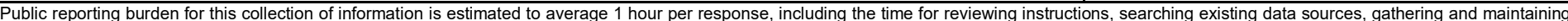

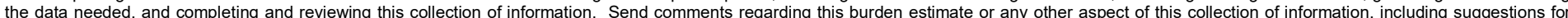

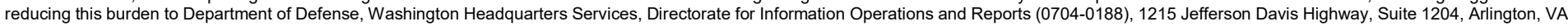

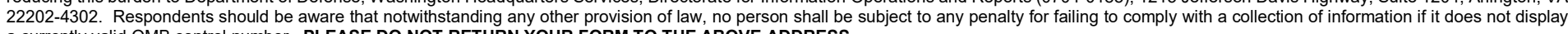
a currently valid OMB control number. PLEASE DO NOT RETURN YOUR FORM TO THE ABOVE ADDRESS.
1. REPORT DATE (DD-MM-YYYY) 2. REPORT TYPE
September 2017 Final report

3. DATES COVERED (From - To)

\section{TITLE AND SUBTITLE}

Hydrologic Engineering Center-River Analysis System (HEC-RAS) Water Temperature Models Developed for the Missouri River Recovery Management Plan and Environmental Impact Statement

\section{AUTHOR(S)}

Zhonglong Zhang and Billy E. Johnson

5a. CONTRACT NUMBER

\section{5b. GRANT NUMBER}

5c. PROGRAM ELEMENT NUMBER

5d. PROJECT NUMBER

396939

5e. TASK NUMBER

\section{5f. WORK UNIT NUMBER}

\section{PERFORMING ORGANIZATION NAME(S) AND ADDRESS(ES)}

8. PERFORMING ORGANIZATION REPORT NUMBER

U.S. Army Engineer Research and Development Center

Environmental Laboratory

ERDC/EL TR-17-18

3909 Halls Ferry Road, Vicksburg, MS 39180-6199

9. SPONSORING / MONITORING AGENCY NAME(S) AND ADDRESS(ES)

10. SPONSOR/MONITOR'S ACRONYM(S)

Headquarters, U.S. Army Corps of Engineers

Washington, DC 20314-1000

11. SPONSOR/MONITOR'S REPORT NUMBER(S)

\section{DISTRIBUTION / AVAILABILITY STATEMENT}

Approved for public release; distribution unlimited.

\section{SUPPLEMENTARY NOTES}

\section{ABSTRACT}

This report describes the Hydrologic Engineering Center-River Analysis System (HEC-RAS) water temperature models for five Missouri river reaches (e.g., Fort Peck Dam to Garrison Dam; Garrison Dam to Oahe; Fort Randall Dam to Gavins Point Dam; Gavins Point Dam to Rulo, NE; and Rulo, NE to the mouth of the Missouri River). These models were developed based on calibrated HECRAS flow models that the Omaha and Kansas City Districts of U.S. Army Corps of Engineers (USACE) provided. Of five HEC-RAS water temperature models, three models were run for an 18-year period (1995-2012) for six alternatives in support of developing the Missouri River recovery program (MRRP) management plan (ManPlan) and environmental impact statement (EIS). The HEC-RAS water temperature model results that were used to establish a baseline and management alternative scenarios are presented in this report. Likewise, the sources of model uncertainty are discussed in this report as well.

\begin{tabular}{|c|c|c|c|c|c|}
\hline \multicolumn{2}{|l|}{$\begin{array}{l}\text { 15. SUBJECT TERMS } \\
\text { HEC-RAS } \\
\text { Water temperature }\end{array}$} & $\begin{array}{l}\text { Missouri River } \\
\text { Recovery prog } \\
\text { Management } \mathrm{p}\end{array}$ & & \multicolumn{2}{|c|}{ Environmental impact statement } \\
\hline \multicolumn{3}{|c|}{ 16. SECURITY CLASSIFICATION OF: } & $\begin{array}{l}\text { 17. LIMITATION } \\
\text { OF ABSTRACT }\end{array}$ & $\begin{array}{l}\text { 18. NUMBER } \\
\text { OF PAGES }\end{array}$ & $\begin{array}{l}\text { 19a. NAME OF RESPONSIBLE } \\
\text { PERSON }\end{array}$ \\
\hline $\begin{array}{l}\text { a. REPORT } \\
\text { UNCLASSIFIED }\end{array}$ & $\begin{array}{l}\text { b. ABSTRACT } \\
\text { UNCLASSIFIED }\end{array}$ & $\begin{array}{l}\text { c. THIS PAGE } \\
\text { UNCLASSIFIED }\end{array}$ & & 118 & $\begin{array}{l}\text { 19b. TELEPHONE NUMBER (include } \\
\text { area code) }\end{array}$ \\
\hline
\end{tabular}

